\title{
LA MASCULINIDAD EN EL TANGO RIOPLATENSE
}



Universidad de Salamanca

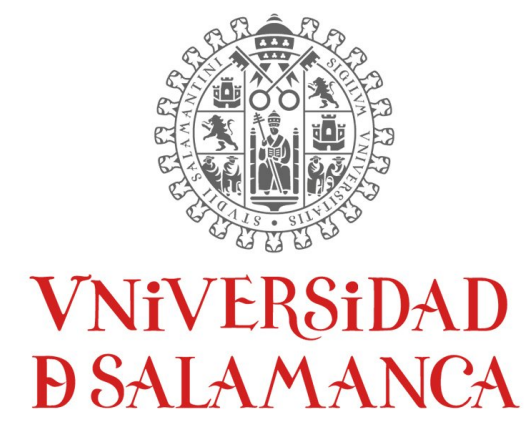

CAMPUS OF INTERNATIONAL EXCELLENCE

\section{LA MASCULINIDAD EN EL TANGO RIOPLATENSE}

Laura Alonso Sáenz de Miera

Director: Dr. Antonio Notario Ruiz

Salamanca, 2021 

A la memoria de Carlos Sáenz de Miera Verdú, voz de mis primeras milongas.

A mis padres y hermanas, por ponerme en el camino.

A Carlos, Carmen y Amalia, por su ayuda y su paciente espera. 

ÍNDICE 

Prefacio IX

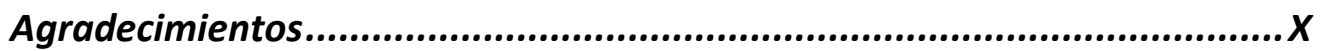

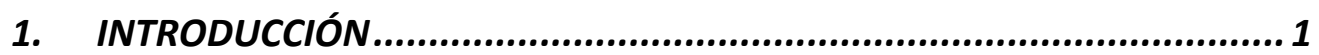

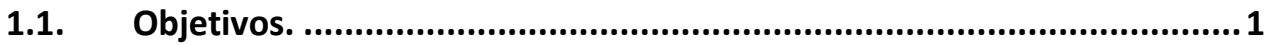

1.2. Relevancia del tema y dificultades encontradas. ................................6

1.3. Fuentes y metodología....................................................................18

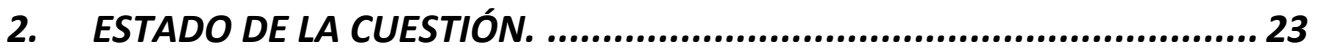

2.1. Tango: relatos y paradigmas. ..............................................................28

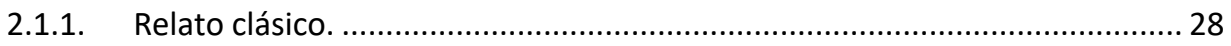

2.1.2. Nuevos paradigmas: El tango en la sociedad porteña ................................... 43

2.1.3. Enfoque sociopolítico................................................................................ 51

2.1.4. Una perspectiva coreográfica. ...................................................................... 56

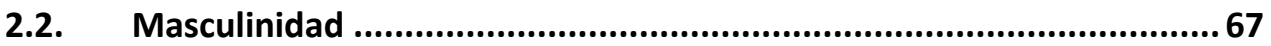

3. LA MASCULINIDAD EN EL TANGO RIOPLATENSE. ......................... 76

3.1. Roles de género masculino en el Río de la Plata (1880-1916)..............80

3.1.1. Un precedente: el gaucho........................................................................ 82

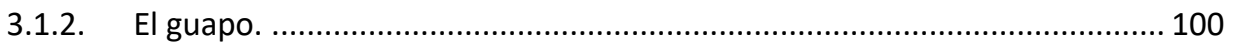

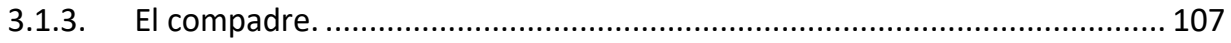

3.1.4. El compadrito.................................................................................... 113

3.2. La masculinidad en el lenguaje...................................................... 121

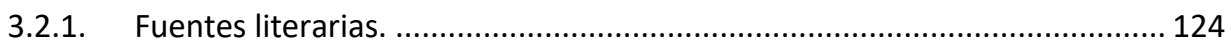

3.2.2. La masculinidad en las letras del tango rioplatense. ……………………... 161

3.2.3. El tango y la masculinidad en el vocabulario lunfardo................................. 185

3.3. La masculinidad en la coreografía del tango..................................... 193

3.3.1. Las danzas que ya existían a finales del siglo XIX y principios del siglo XX... 195

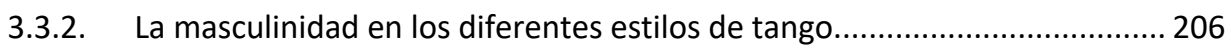

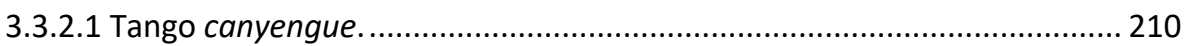

3.3.2.2 Tango milonguero y tango de salón: ..................................................... 220

3.3.2.3 Otros estilos populares. El Tango nuevo.................................................. 225

3.3.2.4 Tango fantasía o tango escenario........................................................ 230 


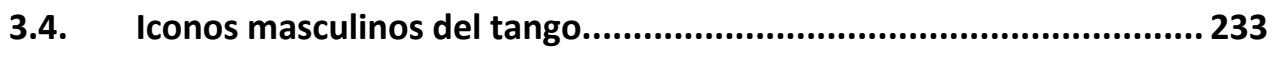

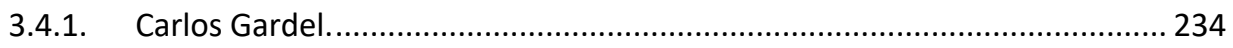

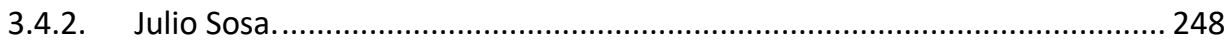

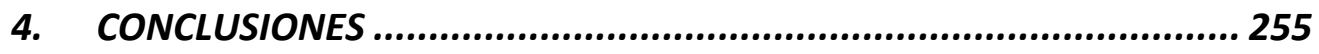

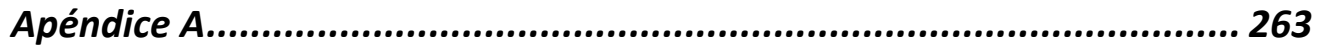

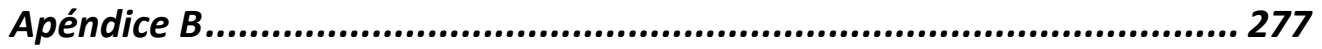

Bibliografía ..................................................................... 278

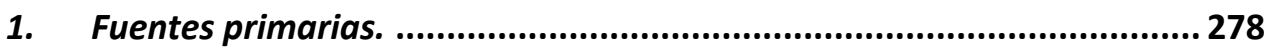

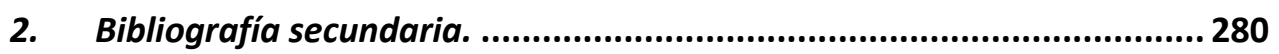

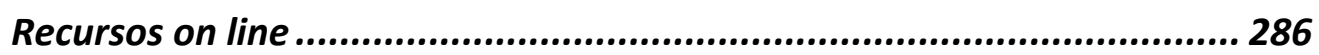




\section{Prefacio}

Podríamos afirmar categóricamente que el mayor responsable de que hayamos dedicado los últimos siete años a estudiar la masculinidad en el tango rioplatense es el escritor argentino Jorge Luis Borges. Con él aprendimos que la vida mitológica del género era mucho más atractiva que la histórica y que esta leyenda, en la que el hombre era protagonista, configuró un género del que decidimos no alejarnos nunca.

Debemos reconocer que la parte de nuestra investigación que más aportó a nuestro conocimiento global sobre el tango fue, por un lado, el momento en el que afrontamos la lectura de todas las letras registradas hasta el momento en el sitio web Todo Tango, más de nueve mil, y nuestra visita a la capital porteña, Buenos Aires. Entramos por ambas puertas al reino de esta música urbana y entendimos lo que hasta ahora la ha definido: el recuerdo del pasado y el hablar de sí mismo. Estos dos elementos, autorreferencialidad y memoria, además de la ciudad de Buenos Aires y las letras de tango nos llevan de nuevo a Borges, quien propuso en cierto momento que el conjunto de letras de tango podría haber dado lugar a un gran poema como la llíada, con la salvedad de situarla en otro tiempo y en otro lugar, Buenos Aires. Sin ninguna duda en el centro de ese poema estaría un hombre intentando ser valiente, intentando no llorar, intentando ser precisamente eso, un hombre.

Este trabajo es el estudio del hombre en el género tango y en todo aquello que contribuyó no solo a su difusión, sino también a su configuración. Estamos seguros de que sin la figura legendaria del varón del tango este no habría sido capaz de conquistar el corazón del mundo. 


\section{Agradecimientos}

Son muchas las personas y las instituciones a las que debo agradecer que este trabajo haya podido llegar a término. El primer lugar en estos agradecimientos lo ocupa, como no puede ser de otra manera, mi familia, sin cuya ayuda habría sido del todo imposible dedicar horas a investigar, escribir y corregir estas páginas.

En segundo lugar, me gustaría dedicar unas líneas a la mayor autoridad en lo que a tango se refiere, la Academia Nacional del Tango de la República Argentina, sita en la Avenida de Mayo de la ciudad de Buenos Aires, donde su presidente Gabriel Soria me recibió con excelente trato. En esta insigne institución encontré, además de un apoyo incondicional, una ayuda constante en la figura del profesor Rubén Berenblum, quien tuvo a bien compartir conmigo durante estos últimos años parte de lo muchísimo que conoce de este género.

Gracias a la Academia Porteña del Lunfardo y, en concreto, a su presidenta Otilia da Veiga y su bibliotecario, Marcos. Agradezco además a Enrique Binda, a Gustavo Varela, a Oscar Conde, a Laura Collavini, a Gaby Ayala y a Martina Iñíguez que aportaran su granito de arena a mis investigaciones desde sus expertos y diversos puntos de vista.

Gracias a la Dra. Marta Rosalía Norese por abrir el camino académico del estudio del tango en la ciudad de Salamanca.

Gracias a Adolfo Pinto por enseñarme lo mejor del tango: su danza. 


\section{INTRODUCCIÓN}

\subsection{Objetivos.}

Como sucede con la mayor parte de los géneros musicales, el Tango atrapa desde los primeros compases a una gran cantidad de oyentes y, en muchos casos, invita no solo a una escucha placentera, sino también a la danza. En menos casos, el interés por esa escucha, esa música y esa danza traspasan el nivel del entretenimiento para llegar al de la investigación académica. Esta segunda fase es la que nos ha conducido a la realización de esta Tesis Doctoral.

Este tipo de trabajos surgen de la necesidad de responder una o varias preguntas, aunque muchas veces ni las preguntas que formulamos estén claras. Nosotros respondemos en estas páginas solamente a una: ¿de dónde procede la imagen que viene a nuestra mente cuando pensamos en una pareja bailando tango? Nuestra respuesta a este interrogante está relacionada con todo un imaginario masculino que se desarrolló en el siglo $\mathrm{XIX}$, diferentes tipos de hombres con un carisma incuestionable entre los que destacó, especialmente en lo que atañe a la música rioplatense, el compadrito. También tiene que ver con una concepción de la danza como un arte en continua evolución y absolutamente determinada por su contexto, el tiempo y el lugar en el que se desarrolla. Además, el análisis de la danza en cualquier circunstancia depende también de quién sea el observador:

«Dancing doesn't signify the same thing across time, across geography, amongst varying populations. Depending on who seeks to define dancing whether professional or social dancer, writer, cleric, physician, philosopher, politician, parent, researcher- and depending on the context in which that person expresses himself or herself, we are presented with described experiences of dancing that can be surprisingly diverse, even contradictory». ${ }^{1}$

${ }^{1}$ Elizabeth Claire, «Dance practice and gendered discourse», Clio. Women, Gender, History, $n^{\circ} 46$ (2017): 9. 
Cuando empezamos a interesarnos por este género musical y su historia, una de las preguntas que nos hacíamos era si tenía algo que ver con el folclore, ya fuera argentino o uruguayo. Era algo evidente que el compás de la milonga había variado en tempo y fraseo —entre otros muchos aspectos, y que la coreografía y el lugar de expansión de ambos géneros nada tenían que ver. Tampoco encontraba relación entre el tango y el malambo o la chacarera, ambas danzas folclóricas especialmente representativas de este territorio. Así que la primera conclusión fue que el tango es un producto urbano y nada tiene que ver con el campo. Preguntamos por aquel tiempo en una conferencia a una experta en el tema y su respuesta fue tan tajante como nuestra conclusión, sin embargo, esta afirmación fue perdiendo peso poco a poco a medida que pensábamos en la relación con el entorno social y más concretamente cuando encontramos cierta semejanza entre los protagonistas de ambos géneros musicales: el gaucho y el compadrito. Entonces empezamos a pensar qué era lo que los unía, qué hilo conductor nos llevaba desde el gaucho al compadrito y, en general, a todos esos tipos que se le asemejaban: el guapo, el compadre o el malevo. Fue entonces cuando nos percatamos de que todos eran prototipos masculinos y de que quizá ahí estaba lo importante, en la masculinidad de la que todos ellos hacían gala. Son los mismos perfiles sociales a ambos lados de un momento bisagra: el cambio del mundo exclusivamente rural al estado moderno.

Brian Bockelman, en un artículo publicado en The American Historical Review nos habla de la existencia de dos símbolos fundamentales de la identidad argentina que a menudo han sido estudiados de manera independiente: el gaucho y el tango. Bockelman se plantea la siguiente cuestión:

«How could both the rural gaucho of old and the novel urban idiom of the tango become more representative of Argentine identity in the early twentieth century?». ${ }^{2}$

2 Brian Bockelman, «Between the Gaucho and the Tango: Popular Songs and the Shifting Landscape of the Modern Argentine Identity, 1895-1915», The American Historical Review, Vol. 116, 3 (2011): 580. 
Este estudioso se centra en la canción de finales del XIX y principios del XX como fuente historiográfica y establece como nexo común entre el gaucho y el tango una figura que define como poco estudiada: el payador. Según él, estos cantores del campo recogieron la herencia del gaucho primitivo y la plasmaron en sus composiciones con las que dieron un impulso importante a la configuración de las bases de lo que se llamará más adelante tango canción.

Estamos de acuerdo con Bockelman en que no es casual que dos elementos en apariencia tan dispersos como el gaucho y el tango se erijan ambos como símbolos nacionales de un mismo territorio. Donde discrepamos es en el nexo de unión. Para nosotros lo que une al gaucho y al tango es la masculinidad heredada del hombre del campo al urbano, representado este último en una serie de prototipos que serán incorporados no solo al imaginario popular sino también al mito de los primeros años de vida del tango rioplatense.

Comenzamos a analizar estos roles sociales y su proyección en el submundo tanguero de la época en la que nace el tango: las dos últimas décadas del siglo XIX y las dos primeras del XX. Así, nos encontramos con un documento que quería dar una explicación al origen del tango y que encajaba en lo que íbamos pergeñando, pero desde una perspectiva coreográfica. Se trata de una grabación del Ballet Folclórico Nacional en la que Santiago Ayala El Chúcaro —director del Ballet desde su fundación en 1986 hasta su muerte en 1994 y quizá el bailarín más importante de folclore argentino- proponía a comienzos de los años 90 —aunque según nos informó una de sus hijas, fue compuesto muchos años antes-su teoría sobre la transformación del gaucho en compadrito y cómo de bailar el malambo pasa a las orillas de Buenos Aires a bailar el tango en los prostíbulos. El Chúcaro pone en el centro a la figura masculina en todas sus variantes. Esto nos llevó a una dimensión del género muy concreta: la imagen pública de la danza. Nos referimos a una dimensión visual del tango, una imagen, un gesto, en definitiva, una puesta en escena y su presentación al mundo.

Nada o poco tienen que ver aparentemente los tangos de finales del siglo XIX con la música de Astor Piazzolla, o la orquesta de Aníbal Troilo con 
el Tango Nuevo. Entonces nos hacemos las siguientes preguntas que matizan aquella de la que partíamos líneas arriba: ¿Por qué en prácticamente todo el mundo la estética de la danza del tango es la misma? ¿Por qué en países alejados del Río de la Plata y alejados entre sí los bailarines de tango se visten de la misma manera o muy semejante? Y lo más importante: ¿qué hay detrás de esa forma de estar, de esa puesta en escena, de esa forma de representar? ¿Qué es lo que manifiesta y a quién alude? Para responder a todas estas preguntas dimos comienzo a una investigación cuyas conclusiones están recogidas en este trabajo, pero es necesario aclarar unas cuantas cuestiones que podrían llevar a confusión.

En primer lugar, el objetivo de este trabajo no es aclarar una realidad histórica acerca del origen del tango, sino que pretende responder a una pregunta que intenta aclarar de dónde viene y por qué fue tan determinante el impacto de la masculinidad en la coreografía del tango. De esa manera pretendemos relacionar la evolución social con la puesta en escena de la danza del tango. No nos interesa dónde y cómo se bailó el primer tango sino por qué en todo el mundo los bailarines de tango de distintas épocas se visten y gesticulan de una manera tan similar. El tango que ha pervivido como danza en todo el mundo es puesto en escena empleando unos elementos muy determinados que tienen que ver con las figuras masculinas de la época, cómo vestían, cómo se movían y cómo se relacionaban.

El mundo masculino en el que nos sumergimos no sólo fue relevante en el siglo XIX, sino que dejó una impronta en la sociedad tan profunda que incluso actualmente se emplea en contextos que sorprenden a quien no es argentino o uruguayo. De la importancia del compadrito y de su perdurabilidad hasta nuestros días da fe el hecho anecdótico de que la universalmente conocida película Grease del año 1978 protagonizada por John Travolta y Olivia Newton John fue titulada en Argentina Grease, el compadrito ${ }^{3}$.

Existen importantes trabajos que relacionan el tango con el conflicto de género, pero estos trabajos se centran fundamentalmente en la figura de la

3 Rosario cine. De Rosario al mundo. Acceso el 20 de marzo de 2021. http://www.rosariocine.com.ar/pelicula/grease-el-compadrito-43. 
mujer como objeto de sometimiento en este género musical fruto de la visión social de la época. También se habla en estos trabajos de la relación entre el hombre y la mujer y sus roles en el tango. Destacamos a este respecto los trabajos de Marta Savigliano y de Magali Saikin a los que aludiremos reiteradas veces en nuestra exposición. Sin embargo y a pesar de tener muy presentes estos trabajos, nos interesaban otros que analizaran la impronta que la visión social del hombre en las distintas etapas del género dejó en su representación más visual: la danza. No hemos encontrado documentación transcendental al respecto, así que destacamos el valor de este trabajo como novedad en el estudio del tango. Proponemos un nuevo punto de vista y, además, ofrecemos un aporte de transversalidad al indagar en expresiones ajenas a la danza como pueden ser el cine o la literatura. En ellas hemos encontrado gran cantidad de elementos que ratifican las tesis expuestas en este trabajo.

El tango existe desde hace más de 150 años y en su trayectoria encontramos varios aspectos que debemos analizar en relación con el tema planteado: cómo ha sido contada su historia, cómo de esa historia surge una mitología y cómo esa mitología supera a la historia; cómo el hombre, la masculinidad y la hombría protagonizan ese relato, cómo se refleja todo esto en la literatura de la época, en la danza y en las letras del tango; y, por último cómo iconos del tango como Carlos Gardel o Julio Sosa contribuyen a mantener esta estética en el tango hasta la actualidad, aunque no siempre fueran adalides del modelo de masculinidad que dominaba en sus respectivas épocas.

Nuestro trabajo tiene que detenerse en etapas cronológicas muy diferentes de la historia del tango, pero debemos destacar especialmente la primera de ellas: el momento en el que se gesta el prototipo masculino que es descrito en el relato que situará ese modelo de hombre en el epicentro de la expresión visual tanguera. Así, establecemos como límites de esa etapa el año 1880, momento de la federalización y del nacimiento de la nueva Buenos Aires, y 1916, año del surgimiento del tango canción y por lo tanto una nueva manera de entender el tango. Si atendemos a lo que Francisco Canaro cuenta 
en sus Memorias ${ }^{4}$ también podríamos haber elegido como cierre de esta etapa los años previos a la Primera Guerra Mundial cuando popularmente se cuenta que el tango empieza a hacerse famoso en París.

Aún así y teniendo esta primera etapa como punto de partida, debemos detenernos en otros momentos como la época gardeliana del cine en los años treinta, las letras de los tangos de esa misma década o la figura del cantor más relevante de los sesenta para demostrar que lo que para nosotros se creó en esos primeros años perduró en la imagen pública del tango hasta la actualidad. Veremos cómo muchos de sus protagonistas conceden una alta importancia a la virilidad en el género tango. Será el caso de Osvaldo Pugliese o Julio Sosa y también de medios de comunicación como Radio El Mundo donde en 1956 se estrena un ciclo titulado «El tango nació varón». Intentaremos demostrar que El Chúcaro tenía razón pero que a su teoría le faltaba un "eslabón”. Éste es, para nosotros, la masculinidad.

Como ya hemos dicho, además de detenernos en momentos cronológicos diversos también debemos destacar el carácter interdisciplinar y transversal de nuestro trabajo. No solo analizamos el tango en su vertiente de danza o canción y sus protagonistas, sino que indagamos en lo que la literatura y el cine quisieron contarnos al respecto. $Y$ no sólo lo que quisieron contar, sino lo que nos transmitieron sin premeditación.

\subsection{Relevancia del tema y dificultades encontradas.}

La importancia de un trabajo sobre el tango, desde la perspectiva que se quiera, se manifiesta en afirmaciones como la de Eduardo Berti:

«El tango, con su mitología, fue acaso el primer relato que le dio unidad, identidad, a ese país que a comienzos del siglo XX parecía una suma de

${ }^{4}$ Francisco Canaro, Mis memorias (1906-1956). Mis bodas de oro con el tango (Buenos Aires: CESA Talleres gráficos S.R.L, 1957), 75. 
países. El tango supo interpretarnos o supimos interpretarnos a través del tango». ${ }^{5}$

Berti no es el único en relacionar el tango con la necesidad de hallar una identidad argentina. Esto tiene sentido si pensamos que el tango nace en un momento crucial para la creación del Estado Moderno en Argentina y, por extensión, en El Río de la Plata. Por otra parte, como analizaremos también en este trabajo, esta modernidad es creada no sólo por rioplatenses sino por los millones de europeos que llegaron al país buscando una oportunidad.

Veremos también cómo quizá lo que se empleó como herramienta para crear esa identidad fue el relato de lo sucedido, y no los hechos ocurridos realmente. La historia del tango, como veremos detenidamente, fue objeto de una gran mitificación. Parte de sus protagonistas y los ambientes en los que se desenvolvían provocaron una gran atracción en los lectores y otro tipo de interesados de varias generaciones. Tal fue el entusiasmo que generó esta historia en bailarines, músicos y oyentes, que llegó a confundirse con la historia real.

El objetivo de este capítulo es plantear los motivos por los que el tema de este trabajo nos parece relevante y fundamental para entender, por una parte, el aspecto sensible del tango y, por otra, cómo la creación y el desarrollo de un género musical es determinante en la configuración social de un territorio, en este caso, el Río de la Plata. Además, presentamos aquí también las principales dificultades con las que nos hemos ido encontrando, fundamentalmente, en la fase de investigación y lectura de las fuentes.

La decisión de afrontar esta investigación fue fruto - además de la lectura de los textos de Borges- de una reflexión acerca de lo que Ramón Pelinski denominó tango nómade o la diáspora del tango ${ }^{6}$. Este género rioplatense se convirtió en universal y conserva rasgos comunes tanto en Argentina y Uruguay como en Japón, Finlandia o España. Se observa en él una especie

${ }^{5}$ Eduardo Berti, Por qué escuchamos a Aníbal Troilo (Buenos Aires: Gourmet musical, 2017), 15.

${ }^{6}$ Ramón Pelinski, El tango nómade. Ensayos sobre la diáspora del tango (Buenos Aires: Corregidor, 2000). 
de acuerdo tácito relacionado con la dimensión visual de la danza que hace que el bailarín o la bailarina de tango se vista igual en dos puntos totalmente alejados entre sí del mundo. ¿De dónde proviene esta apariencia? ¿Qué empuja a personas de muy diferentes costumbres, culturas y tradiciones a adoptar las mismas posturas, emplear el mismo tipo de ropa o gesticular de una determinada manera cuando bailan un tango? Y no sólo en lo que se refiere a la danza como acto musical explícito, sino también en los carteles que anuncian un festival, en portadas de libros y discos o en una determinada manera de posar al ser fotografiados eso sí, siempre, como bailarines.

El tema que tratamos nos parece relevante por varios motivos. El primero es el que ya esbozamos en párrafos anteriores y tiene que ver con la necesidad de estudios que se centren en la descripción y contextualización de la danza del tango. En este caso ofrecemos una perspectiva estética centrada en la danza. Además, este trabajo es fundamental porque nos ayuda a entender lo que era o no importante en una sociedad en un momento concreto, porque nos habla de sus necesidades $y$, finalmente, porque explica en cierta manera el futuro del género del que hablamos. Compartimos con Blas Matamoro y Gustavo Varela la necesidad de estudiar el género sin extraerlo de su contexto y relacionándolo con los vaivenes de una sociedad en continuo cambio.

Analizamos, también, una propuesta concreta que es la que El Chúcaro, el más importante bailarín de música folclórica de Argentina, propuso en el año 1991 en Cosquín. Santiago Ayala El Chúcaro, como director del Ballet Folclórico Nacional ideó una coreografía en la que muestra el modo en el que, en su opinión, tuvo lugar el nacimiento del tango. Era nuestra intención deducir a partir del análisis de varios factores de la época a la que se refiere y de otras posteriores si El Chúcaro podría tener razón y qué parte de su propuesta podría explicar el origen de la imagen rioplatense que nos ofrece el tango. Más allá de que la tenga o no, su relato nos parece que aporta un punto de vista social que no debemos pasar por alto. El Chúcaro fue, además de una persona muy valiosa en su profesión, un gran estudioso que se preocupó por conocer y entender la historia de su país. Su visión de por qué el tango era bailado por compadritos o, mejor dicho, de cómo el compadrito se convierte 
en protagonista fundamental del ambiente tanguero nos habla mucho de la sociedad donde el tango nació. Para nosotros no es importante si sucedió exactamente como él dice, pero el ingrediente masculino impregna toda la propuesta y, a este respecto, sí tenemos mucho que decir.

Antes de continuar debemos aclarar que, siguiendo a autores tan actuales como Héctor Benedetti y su Nueva Historia del Tango ${ }^{7}$ u otros más lejanos en el tiempo como el uruguayo Fernando Assunçao ${ }^{8}$ o Simón Collier ${ }^{9}$, hablaremos en esta tesis de tango rioplatense y no de tango argentino o bonaerense. Y será así por considerar que - a pesar de reconocer ciertas diferencias sobre todo cronológicas - la historia del tango en Buenos Aires y en Uruguay se desarrolla de una manera prácticamente paralela; así lo es también la historia de estos dos países, especialmente en las primeras décadas. Además, el intercambio cultural entre ambas orillas fue constante. A este respecto es interesante el artículo de Enrique Binda « ¿Tango rioplatense o tango argentino?» ${ }^{10}$ en el que nos presenta las diferencias cronológicas entre el tango que se desarrolló en Argentina y el que se vivió en Uruguay. En este artículo Binda deja bien claro -y presenta para ello sólidos argumentos- que la participación de los orientales en el tango tuvo siempre como referencia a músicos y compositores argentinos. El desarrollo del tango uruguayo sobre todo en los primeros años iba un paso por detrás de sus vecinos del otro lado del río. Posteriormente, los protagonistas del género fueron indistintamente argentinos y uruguayos, pero el centro estuvo fundamentalmente en Buenos Aires. A pesar de ello y teniendo en cuenta que no es nuestra intención el esclarecimiento del momento exacto en el que sucedieron los hechos, hablaremos en todo momento de tango rioplatense.

7 Héctor Benedetti, Nueva historia argentina. De los orígenes al siglo XXI (Buenos Aires: Siglo veintiuno editores, 2015).

${ }^{8}$ Fernando Assunçao, Pilchas criollas. Usos y costumbres del gaucho (Buenos aires: Emecé, 2000).

9 Simon Collier, «The popular roots of the argentine tango», History Workshop, 34 (1992): 92.

${ }^{10}$ Enrique Binda, «¿Tango rioplatense o tango argentino?», acceso 18 de enero de 2021,https://www.todotango.com/historias/cronica/212/Tango-rioplatense-o-tangoargentino/. 
Nos interesa, por ejemplo, el compadrito como tipo social, no si aparecieron primero en Buenos Aires o Montevideo.

Pues bien, retomando el porqué de la elección de este tema para desarrollar nuestra investigación, nos gustaría resumir brevemente el momento histórico y político que el Río de la Plata está viviendo cuando tiene lugar el nacimiento del tango.

El 9 de julio de 1816 tiene lugar en el Congreso de Tucumán la Declaración de Independencia de la Argentina, lo que supuso que las Provincias Unidas del Río de La Plata dejaran de responder políticamente ante el gobierno de España. Posteriormente tuvieron lugar sucesivas guerras civiles provocadas por luchas internas entre federales y unitarios y finalmente, a mediados de la década del 20, queda configurada la República Argentina. Después del gobierno de Juan Manuel de Rosas, las presidencias de Urquiza, Mitre, Sarmiento y Avellaneda llegamos al año 1880 en el que comienza el período político que se conoce como República liberal-conservadora y que durará aproximadamente hasta 1916. Esta es la época de configuración del tango y en la que encontramos a nuestros protagonistas: los compadritos. Es una época llena de cambios e incertidumbres que se reflejan en el día a día de un territorio que intenta gobernarse a sí mismo al tiempo que desea formar parte del resto del mundo. Es un tiempo donde a la vez que se crea el estado moderno se diversifica la relación entre los espacios rurales y las ciudades, dando lugar a nuevos sujetos que articulan ambos mundos. Se está creando el estado moderno y todo sucede tan rápido que su organización se hace complicada. Dice Carlos Vega al respecto:

«En Buenos Aires, en la Argentina, los lustros medios del siglo XIX constituyen una línea divisoria. La revolución francesa de 1830 y la de 1848 están abatiendo las costumbres coloniales e introduciendo ideologías nuevas. Se produce la caída de la dilatada dictadura de Rosas 
(1852) y empiezan a abrirse los grandes salones privados o de clubes poderosos para una aristocracia europeizante. Empieza la inmigración». ${ }^{11}$

En cuanto a las características socioeconómicas podemos decir que se trata de una sociedad patriarcal sometida a importantes cambios que tienen como resultado el surgimiento de nuevos tipos sociales. La vida del campo se transforma a la vez que redefine su relación con una urbe cada vez más compleja y se está creando un mundo nuevo en la gran ciudad. Algunas de las personas que trabajaban el campo deben hacerse un hueco en la nueva urbe, pero no es fácil. Muchas veces esto sucede porque ellos mismos no entienden o no comparten el funcionamiento de las leyes que regirán una nueva manera de entender el trabajo del campo. En esa inmensa diversidad, nos interesa especialmente el grupo de hombres que se acercaron a la ciudad pero que tuvieron que afincarse en las orillas. Fue una transición progresiva y todo un mundo se creó en los límites de las ciudades, en lo que conocemos como arrabales. Al mismo tiempo comienza el proceso migratorio más importante de todos los tiempos durante el cual Buenos Aires recibe una ingente cantidad de inmigrantes europeos. Entre 1860 y 1940 Argentina recibió 6.500.000 europeos, y 3.500.000 se afincaron definitivamente en ese país. Buenos Aires, en los veinte años que van de 1895 a 1914 -lapso de tiempo dentro del período que estudiamos- creció de 660.000 habitantes a más de 1.500.000.

Fruto de estas circunstancias -el nacimiento del estado moderno y la inmigración- surge un enclave social protagonizado por hombres y mujeres que crean un submundo - como ya hemos apuntado anteriormente- situado a medio camino entre lo rural y lo urbano, lo antiguo y lo moderno. Según el relato clásico de lo sucedido es en este contexto donde nace el tango. Como se explicará más adelante, en nuestra opinión no fue éste el único contexto donde el tango se desarrolló en sus primeros años, pero adelantamos la idea

11 Carlos Vega, Estudios para los orígenes del tango argentino (Buenos Aires: Universidad Católica Argentina, Instituto de Investigación Musicológica Carlos Vega, 2016), acceso el 31 de octubre de 2020, http://bibliotecadigital.uca.edu.ar/repositorio/libros/origenestango-argentino-vega.pdf. 
que defendemos de que sí fue éste el relato que más influyó social y estéticamente.

Es importante también detenerse un momento para hablar del concepto de nacionalismo — sobre todo en Argentina- puesto que la manera de interpretar el contexto tanguero tuvo mucho que ver también con la necesidad de encontrar rasgos y elementos que pudieran constituir una identidad nacional. A menudo en estas páginas hablaremos de cómo el relato de la historia del tango aportó un contexto social que se convirtió en la base identitaria del pueblo argentino. A este respecto fue fundamental el año 1910, en el que se celebró el Centenario de la Revolución de Mayo que dará lugar a la proclamación de la independencia argentina. En los años del Centenario y entre multitud de celebraciones, se empezó a gestar y a configurar una idea de nacionalidad y de identidad. En este proceso tuvo mucha importancia el aluvión inmigratorio y la necesidad que devino de establecer unos claros rasgos con los que la sociedad pudiera sentirse identificada. Para ello, una de las medidas fue promover un nacionalismo educativo a través de programas y manuales académicos de la mano de personalidades como Ricardo Rojas, Manuel Gálvez o José María Ramos Mejía.

En lo que tiene que ver con el concepto de nacionalismo, el tango jugó un papel a veces contradictorio. Como veremos más adelante, algunos intelectuales lo elevaron a la categoría de símbolo nacional, mientras que otros lo denostaron en favor de músicas más antiguas que consideraban más arraigadas al sentir del pueblo y, en su opinión, más criollas. En uno y otro caso, este género musical fue objeto de polémicas que, entre otros logros, consiguieron añadir algún que otro ingrediente más a la fabulación acerca de su historia. A la larga conseguirán, también, contribuir a su consagración como música que más se identifica con el porteño, el montevideano o, en general, el rioplatense.

Queda claro lo que decíamos en páginas anteriores hablando de las necesidades de la sociedad en un período determinado. En este caso se reclamó una identidad para un pueblo que había acogido a millones de extranjeros y junto a los cuales construyó una nueva manera de entender el trabajo, la economía y la vida social en general. El tango nace en un momento 
clave y tanto su carisma, que atrajo a la juventud en un primer momento, como el relato que se construyó en torno a él, consiguieron convertirlo en un rasgo fundamental de la idiosincrasia rioplatense.

Nosotros, en este estudio, ponemos el foco en la danza. Las letras, el lenguaje que emplea, la trayectoria de sus protagonistas, lo que nos cuentan los intelectuales que hablaron sobre el tango -e incluso lo practicaron en alguna de sus vertientes - y las demás realidades a las que nos referiremos nos sirven para entender por qué ha subsistido esa apariencia con alto grado de masculinidad en los bailarines y en el modo de interpretarse. En definitiva, nos ocupamos de todos los aspectos relacionados con este género musical para, desde todas esas perspectivas, observar la danza del tango.

Han existido y existen actualmente diferentes maneras de afrontar la danza del tango rioplatense, y no todas tienen que ver con lo que actualmente se conoce como tal. Analizaremos los diferentes estilos que existen y a partir de ese análisis veremos qué parte de la coreografía de cada uno es la que triunfa universalmente. $O$ bien, si lo que realmente perdura es la representación de una época de la sociedad del Río de la Plata.

En cuanto a las dificultades con las que nos hemos topado desde el momento en el que nos planteamos desarrollar este trabajo podrían destacarse principalmente dos. Por un lado, la cantidad de estudios que existen sobre el tango - especialmente sobre sus primeros pasos- y por otro, la dificultad de separar la historia de la mitología.

El hecho de que exista mucha información a simple vista parecería una ventaja ya que habría una base teórica firme sobre la que trabajar muchos aspectos interesantes. Sin embargo, la mayor parte de estos estudios no están debidamente documentados — queja muy recurrente en el discurso de muchos de los investigadores más actuales- por lo que plantean muchas teorías que no podemos fundamentar ni argumentar como es debido. Además, como explicaremos con más detalle en el epígrafe dedicado a establecer el Estado de la Cuestión, las principales teorías sobre los orígenes y los primeros años del tango parten cada una de un texto concreto del que luego los demás teóricos se sirven -a veces literalmente- para crear sus propias propuestas sin aportar apenas novedad con respecto al texto 
primigenio. En dicho epígrafe estableceremos tres líneas de investigación y aclararemos si nos adherimos a alguna de ellas o qué recogemos de cada una con el fin de poder contribuir con nuestras aportaciones a un mayor rigor en el análisis social del tango.

Con respecto a la segunda dificultad de la que hablábamos y que tiene que ver con la leyenda creada alrededor de la historia de este género musical hay que decir que, si bien no podemos tomarla como un conjunto de hechos constatables sí podemos analizar - y así lo haremos— la influencia que el relato ha ejercido tanto en el estudio como en la práctica del tango como danza. Repetiremos hasta la saciedad —aun sin ánimo de aburrir al lectorque nos movemos en un terreno entre histórico y legendario y que nuestro objetivo no es hablar de lo que pasó sino explicar de qué manera influyó lo que se contó sobre el tango tanto desde la historia más rigurosa como hasta la leyenda más inverosímil.

Así pues, podemos afirmar que el tango era un género popular en el Río de la Plata ya alrededor del año 1880. Nace como danza y, según los estudios más profundos sobre el tema, encontramos en su origen la mezcla de tres géneros: candombe, habanera y milonga. Sin embargo, estudiosos del tango como la Dra. Marta Rosalía Norese nos cuentan en sus trabajos que no se puede argumentar un origen negro del tango argentino:

«El tema de la influencia negra en el tango insistimos en que más parece una cuestión ideológica: los que se sienten responsables del pobre destino que se le dio a los representantes de la raza negra llevándolos hasta su desaparición, entienden que deben arropar algún legado de su cultura y unirlo a una manifestación tan reconocida y perdurable: el tango». ${ }^{12}$

También Héctor Benedetti en su Nueva Historia del Tango duda de la influencia de los "bailes de negros" en este género:

«Abundan los testimonios de aquellos bailes de negros, aunque sesgadamente descriptos. $\mathrm{Y}$ por cierto no conviene sobreestimar su

12 Marta Rosalía Norese, Contextualización y análisis del tango. Sus orígenes hasta la aparición de la vanguardia (Salamanca: Ediciones Universidad de Salamanca, 2002), 21. 
influencia: no hay constancia alguna de que dichos bailes derivasen más tarde en forma directa en el tango». ${ }^{13}$

Esto chocaría con la opinión de expertos como Juan Carlos Cáceres, Roberto Selles o Ricardo Rodríguez Molas y otros muchos que desde la publicación de Cosas de negros ${ }^{14}$ de Vicente Rossi en 1926 aseguraron siempre que la música negra había ofrecido al tango argentino parte de sus cualidades. Incluso algunos estudiosos analizan esta influencia en estilos como el tango o la murga en épocas posteriores como finales del siglo XX, tanto en Argentina como en Uruguay, como un modo de recuperar parte de sus raíces:

«Desde mediados de los años 80 , muchos músicos jóvenes de la ciudad de Buenos Aires vienen incorporando de forma creciente en sus canciones la sonoridad candombera afrouruguaya, y del candombe argentino (o candombe guariló) en obras difundidas como canción popular urbana, tango, milonga y rock en la ciudad». ${ }^{15}$

En todo caso, en las dos últimas décadas del siglo XIX el tango es una danza alegre que se interpreta en casas y conventillos, en lugares donde se reunía la gente para bailar. La información que describe los lugares en los que se origina la danza del tango o simplemente en los que se bailaba en los primeros años también es foco de polémica. Hemos escuchado históricamente que el tango tiene un origen arrabalero y prostibulario, y este hecho ha dado lugar a una mitología alrededor del género porteño que según algunos poco tiene que ver con la realidad:

«El público recibió esta imagen con aprobación, y hasta podría decirse que la reforzó y canonizó. Esa edulcorada fábula de compadres colaboraba con varios propósitos, entre ellos, liberar tanto a articulistas como a espectadores

${ }^{13}$ Héctor Benedetti, Nueva Historia Del Tango (Buenos Aires: Ed. Siglo Veintiuno, 2015), 22.

${ }^{14}$ Vicente Rossi, Cosas de negros (Buenos Aires: Hachette, 1958).

15 María Eugenia Domínguez, «Música negra en el Río de la Plata: definiciones contemporáneas entre los jóvenes de Buenos Aires», Trans, 12 (2008), acceso el 23 de abril de 2021, https://www.sibetrans.com/trans/article/107/musica-negra-en-el-rio-de-la-platadefiniciones-contemporaneas-entre-los-jovenes-de-buenos-aires. 
de los aburridos pormenores de una evolución técnica que, seguramente, no comprendían ni buscaban comprender. Y, además, sirvió para sustentar argumentos de sainetes, radioteatros, películas, poemas evocativos y hasta de conversaciones de protagonistas auténticos». ${ }^{16}$

Sin negar el interés que puede despertar la polémica acerca de esta mitología llena de inmigrantes, prostitutas y ambientes "de humo", en este trabajo hemos buscado también referencias que nos ayudaran a reconstruir en la medida de lo posible la imagen visual de los primeros años del tango. Es realmente interesante toda la literatura que se ha escrito teniendo esta música como protagonista y, -aunque no siempre sea del todo realistacreemos que todos estos mitos han contribuido al desarrollo del género musical que llamamos tango. Hemos intentado buscar la parte de realidad que hay en todas estas historias y de qué manera también han podido influir las versiones más literarias. En este caso y para concretar nuestro trabajo, hay que decir que el objetivo es dar cuenta del impacto que ejerció la masculinidad en la coreografía y, en general, en la imagen pública del tango.

Además de un acercamiento al contexto histórico y político de la época que hemos planteado, haremos un análisis sociológico acercándonos a los diferentes roles que el género masculino ejercía en esta época y cómo esos roles tenían también un lugar de esparcimiento en la danza del tango. Intento demostrar que esos roles —o su desarrollo social- están representados en la coreografía que se fue creando desde finales del s. XIX y que aún se conserva en pasos y gestos que se siguen empleando en la danza actual del tango.

Hay que aclarar que en este trabajo expondremos no sólo el relato clásico del surgimiento y desarrollo del tango, sino también el más actual que desmiente, desde finales del siglo XX, ciertos mitos como que el tango no fue siempre socialmente aceptado. También hablaremos del estado actual de las investigaciones. Sin embargo, por ser estas nuevas teorías más jóvenes, hemos decidido referirnos a los diferentes períodos del tango tal y como nos

\footnotetext{
${ }^{16}$ Héctor Benedetti, Nueva Historia Del Tango (Buenos Aires: Ed. Siglo Veintiuno, 2015), 11.
} 
fue contado hasta ese momento en el que se produce un cambio de paradigma. Además, analizaremos una tercera vía teórica que, aunque parte de finales de los 60 , fue desarrollada en una interesante tesis doctoral en el año 2014 redactada por el profesor Gustavo Varela.

El tango ha sido un canal muy eficaz a la hora de transmitir la cultura rioplatense $y$, aunque ahora sea practicado y escuchado por una minoría, ha sido capaz de hacer llegar la cultura del lugar donde nació a todo el mundo. Nos interesa especialmente cómo fue contada su historia y, sobre todo, su recepción y transmisión a generaciones posteriores.

En el análisis de los roles que el género masculino ejercía en esta época en esta sociedad patriarcal son especialmente interesantes las figuras del guapo, el compadre y el compadrito, además de su innegable precedente, el gaucho. Existe también una serie de tipos masculinos de menor relevancia que trataremos de analizar y dejar constancia de su relevancia social, nos referimos al malevo o al niño bien nombrado por Borges, por ejemplo. De todos estos tipos se analizará también qué relación tuvieron con el tango, con el baile en general y concretamente de qué manera participaron en el devenir de este género.

Aunque esta investigación — por razones de espacio y tiempo- tenga como objetivo destacar el papel de la imagen del hombre en la coreografía del tango, no debemos olvidarnos del rol femenino, que también fue determinante, aunque según nuestro criterio, no tanto en el impacto visual, en la forma. Fue, en nuestra opinión, absolutamente relevante en la vertiente textual del tango que dio lugar a prototipos que protagonizarán gran parte de las letras durante varias décadas. Deberá ser además un punto de partida para posteriores trabajos que nos ayuden a completar el puzle social y estético del tango.

Además, tendremos que analizar el mito tan conocido de que el tango al principio fue bailado entre hombres. Nos movemos continuamente entre mitos y leyendas que, a pesar de no haber sucedido como nos contaron, tuvieron una importancia social determinante. Esto es habitual en los estudios relacionados con la cultura y la sociedad rioplatense, especialmente en el lado argentino. Los hombres bailaban juntos, sí, pero para practicar, ensayar y aprovechar el tiempo entre amigos antes de encontrarse con las mujeres. No 
hay documentación que nos haga pensar en otras razones. Hablamos de este tema cuando describimos el estilo de tango que para muchos especialistas fundamentalmente, profesores- es el primigenio, el llamado canyengue. Esto es así porque la época en la que se supone que los hombres interpretaban el tango sin contar con la mujer, coincide con el surgimiento de ese primer estilo de tango.

Por último, hemos investigado y analizado lo más pormenorizadamente posible la letra y la danza del tango en esa primera época y también en algunas posteriores para intentar relacionarlas con las actitudes descritas en los diferentes roles masculinos. Nos pareció interesante también, con el objetivo de demostrar que este modo de bailar está absolutamente enraizado en el tango, comprobar en qué medida estos gestos y coreografías de la danza del tango están presentes en el modo de bailar actual. El hecho de que más de 140 años después de su aparición estas actitudes al bailar se mantengan a pesar de la rápida evolución del género, nos puede ayudar a demostrar que son parte inseparable del tango, que sin ellos el tango podría cambiar, cuando menos, de nombre.

En conclusión, nos movemos en un terreno tanto histórico como sociológico con un ingrediente de lo que denominamos como mitología o leyenda popular. Nos hemos basado en la observación, lectura y análisis de manifestaciones artísticas y hemos tenido que estudiar figuras altamente mitificadas por los medios de comunicación, el cine y también en el contexto intelectual. Intentaremos ser capaces de demostrar que antes de que los estudiosos se propusieran contar la historia del tango desde un punto de vista más académico, se creó un relato acerca de sus orígenes en el que el hombre como varón vanidoso y jactancioso se presenta como protagonista y que su popular figura influyó en gran medida en la visión externa de esta danza y en su recepción en cualquier parte del mundo.

\subsection{Fuentes y metodología.}

Este trabajo describe el proceso de creación de un símbolo y, para llevar a cabo esta descripción, hemos tenido que detenernos en diversos lugares y 
muy distintos momentos. La historia del tango nos lleva directamente al Río de la Plata, a los arrabales, a los salones aristocráticos, a los textos de Borges, a las poesías de Evaristo Carriego, pero también a las películas de Carlos Gardel o a los mundiales de tango. Por todos esos lugares ha transitado este popular género musical y de ello nos hablan todas las fuentes de información a las que hemos recurrido para desarrollar nuestra investigación.

Debemos aclarar, antes de citar los recursos empleados, que el tipo de fuentes escogidas ha dependido mucho de en qué momento de ese camino nos hallábamos. Hemos querido saber cómo se había contado la historia del tango y para ello recurrimos a fuentes secundarias, pero también analizamos canciones, espectáculos de baile, textos literarios y a estos últimos debemos englobarlos dentro de lo que conocemos como fuentes primarias.

Además, nos hemos visto en la obligación de analizar y comentar una serie de fuentes inéditas que tienen que ver con la situación actual de la investigación alrededor del tango rioplatense. La investigación sobre el tango está en auge sobre todo en Buenos Aires y allí conocimos y hablamos con investigadores que están desarrollando un importante trabajo, aunque sus conclusiones y su documentación aún no están escritas.

Por último, esta visita a Buenos Aires a la que acabamos de aludir es considerada en este trabajo una fuente primaria fundamental para entender el momento en el que actualmente se encuentra el tango entendido como elemento social inserto en un contexto determinado. Ya no solo importa cómo se baila el tango, cómo se canta o qué dicen sus letras, sino que se ha convertido en el centro de conversaciones cuyos objetivos primordiales van más allá de la música. El modo en el que una u otra persona habla del tango determina su posición en la sociedad. El pueblo rioplatense ha mostrado históricamente una pasión a veces desmedida pero muy carismática en sus reacciones ante acontecimientos y figuras mundialmente famosas como Eva Duarte de Perón o Diego Armando Maradona. El tango se une a esta lista con sus luces y sus sombras o, lo que es lo mismo, con su historia y su leyenda. Recordamos a este respecto la idea del homo simbolicus de la que hablaba Gilbert Duran en 1960: 
«Para Durand, el ser humano es un homo simbolicus, es decir, tiene la capacidad de transformar en símbolo la realidad que lo rodea y los estímulos que esta le produce para, posteriormente, transferirlos a sus creaciones». ${ }^{17}$

Nosotros hemos recorrido el proceso de creación de ese símbolo que hombres y mujeres de diferentes épocas llevaron a cabo y cuyo culmen supuso el encumbramiento de un género popular hasta convertirlo en una muestra de hombría y masculinidad que definiría al hombre como tal:

«Mientras tanto, las masculinidades que se van construyendo en el tango siempre tendrán que rendirle cuenta a su ideal: ya sea 'batiéndose en duelo' o 'con complicidad de compadres', esto es, siempre funcionará como punto de referencia...... ${ }^{18}$

Como ya hemos dicho, el primer paso en nuestra investigación fue determinar las diferentes maneras como había sido contada la historia del tango y para ello recurrimos a gran cantidad de fuentes secundarias. Ya dijimos al hablar de los inconvenientes de abordar un estudio sobre el tango que la cantidad de libros, artículos y otro tipo de trabajos era ingente. Sin embargo, una vez llevada a cabo la ardua tarea de leer gran parte de esos trabajos entendimos que podíamos realizar una triple clasificación. Por un lado, estaban los que seguían grosso modo las directrices de la primera Historia del tango como tal, escrita en 1936 por Héctor y Luis Bates. Otro camino diferente seguían los estudios que parten del nuevo orden teórico que supuso la investigación de Enrique Binda y Hugo Lamas de la que da muestra su libro El tango en la sociedad porteña. Y, por último, encontramos los trabajos de Blas Matamoro y Gustavo Varela que ofrecían una perspectiva algo disímil de las anteriores. El análisis de todas estas fuentes protagoniza nuestro Estado de la Cuestión. A continuación, y dentro de este mismo capítulo hemos presentado la coreografía creada por El Chúcaro en la que

17 María Rosario Mondéjar Manzanares, «Estudio arquetípico y mitocrítico sobre la mujer en la literatura medieval francesa (siglos XII-XV)», (tesis doctoral, Universidad de Salamanca, 2020), 26.

18 Javier Gasparri, «Che varón, Masculinidades en las letras de tango», Caracol 2 , (2011): 189, acceso el 23 de abril de 2021, https://www.revistas.usp.br/caracol/article/view/57660. 
propone su personal visión de cómo sucedieron los hechos que dieron lugar al germen del tango. Con el análisis de esta puesta en escena se cierra el capítulo dedicado a exponer los diferentes modos de relatar la historia del tango. De ahí en adelante, el análisis de las fuentes tendrá como objetivo presentar nuestra propia propuesta.

Por otra parte, debido al hecho de que en este trabajo relacionamos continuamente los conceptos tango y masculinidad, hemos querido dejar constancia, también en ese segundo capítulo, del camino recorrido por los estudios sobre este segundo aspecto.

Para analizar la presencia del tango y la masculinidad en la literatura, el cine o el propio género y así comprender cómo ese símbolo ha ido integrándose en el imaginario popular hemos recurrido a las fuentes primarias: el habla popular, la literatura, el cine, las letras de tango y las opiniones de los protagonistas. Los resultados de estos análisis los hemos plasmado en el tercer capítulo de este trabajo donde queda clara la presencia del tango y de la masculinidad como elementos que quieren ser presentados como complementarios. Se trata del cuerpo del trabajo y antes de abordarlo hemos considerado imprescindible describir lo más detenidamente posible los tipos masculinos de los que vamos a hablar reiteradamente en todo este capítulo. Como veremos, la línea que separa historia y leyenda es muy fina y muchas veces cuesta distinguir unos prototipos de otros así que la descripción de todos ellos se presenta como un trabajo de gran relevancia.

Una vez expuestos los rasgos que definen estos prototipos buscamos su reflejo en varios elementos que tienen que ver, en primer lugar, con el lenguaje: la literatura, las letras de tango y el lunfardo, lenguaje popular de las orillas del Río de la Plata. A continuación, analizamos los cinco estilos de tango para discernir en cuáles de ellos vemos consolidada esa imagen que tiene que ver con los movimientos y la personalidad de los arquetipos masculinos. Para ello hemos recurrido a audiovisuales en los que hemos podido apreciar qué distingue un estilo de otros y, además, hemos expuesto la opinión de expertos investigadores y profesores que nos ayudan a entender por qué la impronta masculina no está presente de la misma manera en unos estilos y en otros. 
Asimismo, para demostrar que esta estética perdura en la actualidad necesitábamos un eslabón más y lo encontramos en dos de las figuras ilustres —quizá las más importantes- del tango canción: Carlos Gardel y Julio Sosa. Sus vidas, su imagen y el modo en el que fueron contadas sus respectivas historias componen un interesante material para entender por qué se mantuvo viva la llama de la masculinidad en el tango y, más concretamente, en su danza.

Por último, presentamos nuestras conclusiones en las que hemos resumido las ideas principales que han sido extraídas del análisis de nuestras fuentes y que conforman lo que consideramos una gran aportación académica al conocimiento de una de las danzas de raíz más conocidas del mundo.

Finalmente, dejamos constancia de que, en cuanto a la edición de nuestro trabajo, hemos seguido de forma exhaustiva el Manual de estilo Chicago Deusto, una edición de la guía Chicago adaptada al español por la Universidad de Deusto. Todos los aspectos relacionados con edición, estilo y documentación están determinados por las indicaciones de este manual. 


\section{ESTADO DE LA CUESTIÓN.}

Debido a la importancia que tiene en este trabajo el hecho de comprender cómo ha sido contada la historia del tango, este capítulo no supone un mero acercamiento a los estudios existentes relacionados con la materia. No sólo queremos establecer el punto del que partimos después de consultar la documentación existente al respecto. Esta parte debe ser entendida como fundamental dentro del cuerpo de nuestro estudio, puesto que lo que escritores, estudiosos, historiadores, músicos e intelectuales han dicho sobre el nacimiento y desarrollo del tango, en nuestra opinión, ha determinado claramente su evolución.

La bibliografía sobre tango es, ante todo, inabarcable. Desde sus inicios a finales del s. XIX y sobre todo a partir de la primera década del XX se han escrito cantidad de ensayos, artículos periodísticos, novelas, obras de teatro, etc. Por ello, analizar el estado de la cuestión en esta investigación se vuelve tarea realmente complicada. Sin embargo, es importante establecer con claridad cuál ha sido el punto de partida de nuestro planteamiento y qué parte de esa bibliografía nos parece relevante para esta investigación. Hablaremos en este punto de tres corrientes significativas en lo que a estudios sobre tango se refiere y que nos permite dividir las referencias documentales a su vez en tres grandes grupos. Hablamos de corrientes y no de etapas porque en un mismo período de tiempo conviven más de una de ellas. Las dos primeras se separan en un momento de cambio teórico en el que la historia -o los estudiosos de ella- renuncia a la tradición de considerar como cierto un origen prostibulario del tango.

Importantes estudiosos escribieron sobre los orígenes de este género antes de que en 1936 se publicara la Historia del tango de los hermanos Bates ${ }^{19}$, considerada la primera. Sin embargo, en nuestra opinión, el primer texto que podría haber intentado hacer una historia del tango es el artículo

\footnotetext{
19 Héctor Tomás Octavio Bates nació en Buenos Aires el 22 de marzo de 1894. Fue autor y director radioteatral, periodista y compositor de música popular, preferentemente de valses. Su hermano Luis Jorge, nació en San Juan el 3 de febrero de 1907. Fue periodista, autor y escritor, pero a diferencia de Héctor no fue músico ni compositor. Ambos escribieron la Historia del tango en 1936, basándose en conversaciones y entrevistas a algunos de los protagonistas del género.
} 
periodístico «El tango, su evolución y su historia. Historia de tiempos pasados. Quiénes lo implantaron» publicado en el diario Crítica en una fecha mucho más temprana, el 22 de septiembre de 1913 y firmado con el seudónimo de Viejo tanguero. Sin pretensiones historiográficas escribe -bajo el seudónimo Sargento Pita- José S. Álvarez en 1903 sobre el tango de compadritos en la revista Caras y Caretas como algo pasado. En 1926 se publica Cosas de Negros, donde Rossi sitúa el origen del tango en la milonga montevideana y propone la existencia de una marcada influencia negra en el género. Carlos Vega (1898-1966), primer musicólogo argentino, dedica su vida a estudiar la música folclórica y dedica también parte de su estudio al tango. Vega defendió un origen hispanista ${ }^{20}$ del tango en sus escritos inéditos pero que según Paulo $K^{K}{ }^{21}$ son la base de una importante obra llamada Antología del tango rioplatense ${ }^{22}$. A pesar de estos trabajos podemos establecer la Historia del Tango de los hermanos Bates como el punto de partida del relato clásico, puesto que fue el texto al que hacen referencia las investigaciones posteriores. Consideraban que el tango era un producto de los bajos fondos de Buenos Aires donde se mezclaban compadritos, prostitutas y cafishios $^{23}$ en ambientes de humo y alcohol.

Sin embargo, en trabajos más recientes encontramos un análisis diferente del origen del tango. En este amplio grupo tenemos — por ejemploa Hugo Lamas y Enrique Binda como pioneros y a Marta Rosalía Norese, Héctor Benedetti, María Julia Carozzi o Adrián Placenti que consideran la antigua versión una mitificación por parte de las élites que poco o nada se corresponde con la realidad. Plantean que el tango era interpretado también en lugares considerados decentes como teatros frecuentados por las clases sociales más favorecidas. Emplean argumentos como el que Benedetti nos propone:

${ }^{20}$ Empleamos el término "hispanista" por ser el empleado en el artículo al que nos referimos y que citamos en la nota al pie 21 de este trabajo.

21 Pablo Kohan, "Carlos Vega y la teoría hispanista del origen del tango», FILO: Digital, vol. 34 (Buenos Aires: Facultad de Filosofía y Letras, UBA, 2007), http://repositorio.filo.uba.ar/handle/filodigital/7626.

22 Jorge Novati, ed., Antología del tango rioplatense, vol. 1 (Buenos Aires: Instituto nacional de Musicología Carlos Vega, 1980).

${ }^{23}$ El término cafishio en el habla coloquial lunfarda significa "proxeneta". 
«...hacia fines del siglo XIX aparecen las primeras referencias que podrían asociarse con la música y el baile que prosperarían hacia el tango conocido. En ellas no hay alusiones a prostíbulos, arrabales de mala fama ni bailes entre hombres. Ni siquiera se mencionan lugares que después se convertirían en canónicos, como La Boca, Retiro o los Corrales Viejos. En concreto se registran tangos en ocasiones de bailes sociales que nada tienen que ver con las clases bajas, en correctos teatros, sin que se verifiquen incidentes, bailados por parejas mixtas e irreprochables...». ${ }^{24}$

La Dra. Marta Rosalía Norese, en su Tesis Doctoral presentada en la Universidad de Salamanca en el año 2002, duda también de la versión prostibularia cuestionando las viejas teorías y se une, por tanto, a la nueva corriente que reclama mayor rigor histórico al recrear los primeros años del tango.

En cuanto a la bibliografía que presenta esta nueva visión podemos establecer como texto de referencia — por cuestiones de cronología- el libro de Hugo Lamas y Enrique Binda, El tango en la sociedad porteña publicado por primera vez en $1998^{25}$ Se trata de un documentado trabajo de investigación basado en informes policiales y pruebas que ellos consideraron irrefutables.

Lo que podríamos llamar tercera "vía" — considerando la primera la clásica y la segunda la iniciada por Lamas y Binda - tiene que ver no tanto con establecer datos concretos de cómo, dónde o cuándo surge el tango sino con analizar el contexto social y político de la época en la que nace y empieza a desarrollarse el tango. Este análisis está planteado en la Tesis de Doctorado del Prof. Dr. Gustavo Varela titulada Regularidades y rupturas: un análisis genealógico de la historia del tango argentino (1880-1968). Acerca de la primera época que a nosotros nos interesa analizar podemos leer en esta tesis: 2015), 35-36.

${ }^{24}$ Héctor Benedetti, Nueva Historia Del Tango (Buenos Aires: Ed. Siglo Veintiuno,

${ }^{25}$ Hugo Lamas y Enrique Binda, El tango en la sociedad porteña. 1880-1920 (Stuttgart: Editorial Abrazos, 2008). 
«El tango surge a lo largo de la década de 1880 en Argentina, en relación con un doble proceso económico vinculado al programa modernizador del Estado nacional argentino: la adopción del modelo agro-exportador, lo que significa una concepción económica del territorio y de la necesidad del incremento y administración de la población; y la emergencia de una nueva economía de los cuerpos y de un discurso sobre la sexualidad en la que se inscribe el aumento de la prostitución y con ello, la necesidad de control e intervención sobre ella por parte del Estado. La modalidad prostibularia del tango hace que se lo asocie a la "mala vida", a la inmigración "indeseada" y a una forma de decadencia de lo nacional». ${ }^{26}$.

Un texto muy anterior al de Varela planteaba ya este punto de vista social. Se trata de La ciudad del tango, de Blas Matamoro ${ }^{27}$. Hablaremos de él en páginas posteriores, aunque podemos adelantar ya que lo consideramos fundamental para entender, no sólo la teoría de Gustavo Varela sino también, en general, la historia social del tango.

Incluimos además una propuesta original con respecto a las anteriores por presentarse en formato de coreografía. Es la que Santiago Ayala, El Chúcaro, nos propone al hacer una historia del tango empleando como canal de transmisión una coreografía interpretada por el Ballet Folclórico Nacional.

Este podría considerarse un resumen del corpus teórico que nos hemos encontrado al comienzo de nuestra investigación. Las cuatro versiones de la historia han sido imprescindibles para establecer nuestra base teórica y para entender mejor el desarrollo del género Tango. Planteaba ya en un capítulo anterior la dificultad —o la necesidad- de distinguir entre unas y otras y al mismo tiempo no desperdiciar ninguna. Tarea difícil, pero que asumimos por considerar que cada uno de estos trabajos nos aportan elementos de los que no podemos prescindir. De hecho, la existencia de cuatro puntos de vista diferentes nos animó a buscar elementos comunes que pudieran explicar el hecho de que una versión no excluya a las otras. Uno de estos elementos,

26 Gustavo Varela, «Regularidades y rupturas: un análisis genealógico de la historia del tango argentino (1880-1968)» (tesis doctoral, Universidad de Buenos Aires, 2014), 2.

27 Blas Matamoro, La ciudad del tango. Tango histórico y sociedad, $2^{\mathrm{a}}$ ed. (Buenos Aires: Editorial Galerna, 1982). 
para nosotros fundamental, es la masculinidad. La diferencia que percibimos entre ellos va más allá de los hechos que cuentan. Se trata fundamentalmente de la intención de cada uno de los autores en el momento de intentar explicar qué pasó para que el tango naciera y creciera como lo hizo. La historia de los hermanos Bates es un compendio de anécdotas narradas por los protagonistas y por lo tanto vemos en ella una intención de contar cómo vivieron las distintas etapas del tango sus protagonistas. Parecería más una crónica social que un documento histórico. La segunda, inaugurada por Lamas y Binda, pretende alejarse un poco de la historia narrada por músicos para aportar toda la objetividad posible a través de una interesantísima documentación. El enfoque aportado por el trabajo de Blas Matamoro y posteriormente el de Gustavo Varela nos aportan una visión social del tango, su relación con los cambios de la sociedad determinados, en gran medida, por la trayectoria política de Argentina. Por último, vemos también una intención sociológica en la propuesta de El Chúcaro, ya que basa su historia en uno de los personajes protagonistas de la sociedad del momento.

La existencia de los tipos masculinos a los que nos referimos en nuestro trabajo se encuentra en todas las referencias a la historia del Río de la Plata en ambas márgenes. Siendo innegable su existencia, lo que pretendemos es definir su influencia en el tango y -sobre todo- en la definición de su coreografía, especialmente en algún estilo concreto de tango. Como ya hemos apuntado - y esto es algo que se repetirá varias veces a lo largo de nuestro trabajo-nos interesa no sólo el papel real que el hombre jugó en los primeros años del tango, sino también - $\mathrm{y}$, sobre todo— la mitología creada alrededor de su figura; esa historia paralela que tanto influyó en la creación de una estética que llega hasta nuestros días.

Dejando para otro capítulo independiente a la literatura como fuente, presentamos a continuación el análisis de cada uno de estos tres caminos por los que nos llevan los historiadores, los sociólogos o, simplemente, los protagonistas. A través de la literatura avanzaremos por otros caminos transitados por autores de gran reconocimiento, —no sucede así en el caso de los estudiosos del tango- lo que implicará, sin ninguna duda, relacionar sus escritos acerca del tango con sus obras universalmente conocidas. 
Como última aclaración antes de comenzar nuestro análisis debemos señalar de nuevo que la cantidad de libros, artículos, trabajos académicos y en general de documentación acerca del tango es ingente e inabarcable. Para establecer el presente Estado de la cuestión hemos seleccionado a los autores que nos parecen más destacables en cada una de las teorías expuestas, no sólo por lo que cuentan sino por la influencia que tuvieron en estudios posteriores.

Además, una vez finalizada la exposición de estos tres relatos de la historia del tango, así como de las actuales investigaciones en curso, trataremos el tema de la masculinidad como objeto de estudio, aunque como expondremos detenidamente, estas investigaciones no son tan numerosas, especialmente si nos atenemos a los estudios de la masculinidad en relación con el tango. Con esto completaremos nuestra exposición de cómo se ha hablado del tango y de la masculinidad desde el punto de vista académico.

\subsection{Tango: relatos y paradigmas.}

\subsubsection{Relato clásico.}

Cuando los hermanos Bates publicaron la que se considera la primera Historia del Tango ya había mucho escrito sobre este género musical. Desde los primeros años del s. XX algunos especialistas como Vicente Rossi ya se habían preocupado de plasmar en diversos trabajos su visión acerca de su origen, de las danzas de procedencia o del ambiente en el que se había gestado el tango, en un principio, como danza. El documento más antiguo del que tenemos noticia referido a la danza del tango lo aportan Enrique Binda y Hugo Lamas y data de $1888^{28}$. En 1903 ya se hablaba en la revista satírica Caras y caretas del tango compadrito como algo pasado ${ }^{29}$ y el primer artículo

28 Hugo Lamas y Enrique Binda, El tango en la sociedad porteña. 1880-1920 (Stuttgart: Editorial Abrazos, 2008), 99.

29 Sargento Pita [seud.], «El tango criollo», Caras y Caretas nº 227 (1903). A partir de este momento aludiremos frecuentemente a artículos extraídos de esta revista. Para mayor comodidad del lector apuntamos a continuación el enlace a la revista y en notas posteriores indicaremos concretamente número, año y, si procede, página donde se encuentra el texto al que nos referimos. El enlace es el siguiente: http://hemerotecadigital.bne.es/results.vm?q=parent:0004080157\&lang=es 
con pretensiones de hacer historia acerca del tango fue publicado por El Viejo tanguero en $1913^{30}$. En agosto de 1925 la revista Martín Fierro ya recoge un resumen de lo que ha sido la historia del tango en un artículo firmado por Sergio Piñero ${ }^{31}$. En todos estos documentos se nos habla del tango como baile de compadritos, excepto en el de 1888, que se refiere a un baile de máscaras en un teatro, aunque aparecen referencias a gestos indecorosos y poco propios de gente educada.

En el año 1998 con la publicación de El tango en la sociedad porteña de Lamas y Binda se produce un antes y un después historiográficamente hablando. Parece que en los últimos 30 años toda la gran leyenda del tango, la que contribuyó a hacerlo universal, la que interesó a los grandes literatos de Argentina, Uruguay y el resto del mundo ha sido desmentida. Nuevos estudiosos como los autores de ese importante libro, Hugo Lamas y Enrique Binda, y otros como Héctor Benedetti o la Dra. Marta Rosalía Norese nos cuentan ahora que toda esa leyenda se fraguó de una manera literaria y elitista y que las pruebas documentales demuestran que ni el tango tuvo un origen exclusivamente prostibulario ni fue tan denostado por las clases más pudientes de la sociedad rioplatense como se nos quiso hacer entender.

Este devenir historiográfico requiere un análisis más exhaustivo por nuestra parte, ya que en este estudio se defiende la capacidad que tuvo ese relato — si se quiere, legendario- de influir estéticamente en el desarrollo y la universalización del tango rioplatense. Creemos que esa historia tan contada, no sólo popularmente sino también negro sobre blanco de la mano de intelectuales tan importantes como Borges o Sábato, fue lo que atrajo a millones de personas y lo que hizo que medio mundo se enamorara de esta danza convertida más tarde en canción.

Comenzaremos, pues, con el análisis de lo que podríamos llamar el relato clásico, aquel que está más arraigado en el saber popular y que más hondo ha calado en el imaginario tanguero de todo el mundo.

${ }^{30}$ El Viejo tanguero [seud.], «El tango, su evolución y su historia», Crítica, 9 de septiembre de 1913.

${ }^{31}$ Sergio Piñero, «Salvemos el tango (continuación)», Martín Fierro n²0, (1925): 144. 
Se podría asegurar que lo que la mayor parte del mundo conoce -0 , mejor dicho, cuenta- acerca de la historia del género tango es su origen prostibulario. El mundo se sintió atraído desde comienzos del siglo XX por esos compadritos que bailaban milongas en los peringundines del arrabal de Buenos Aires entre alcohol, humo y mujeres. La leyenda habla de parejas de hombres bailando milongas en las veredas, de peleas valientes, de coraje, de letras obscenas que tenían que ser camufladas bajo títulos decentes, de conventillos llenos de inmigrantes venidos de diferentes partes de Europa inventándose un nuevo lenguaje y, por encima de todo, del prostíbulo como lugar de encuentro y de baile preferido para los tangueros o, más apropiado para ese tiempo, milongueros.

Los hermanos Bates escribieron su Historia del Tango en el año 1936 y en ella defienden la triple paternidad del tango: candombe, habanera y milonga. Atendiendo a lo que tiene que ver con la danza nos interesa lo que nos cuentan acerca de la milonga, de donde procedería la coreografía del tango:

«En ella, el compadrito criollo había encontrado campo propicio para lucir sus naturales disposiciones para la danza. Los antiguos bailes no permitían aquellos rozamientos con la pareja....12

Nos han presentado ya al protagonista de la historia, el compadrito. Es especialmente relevante su reflexión acerca de lo que llaman el elemento masculino:

«El elemento masculino no iba a la zaga en cuanto a la nada envidiable reputación que acompañaba a las mujeres, y los que no habian tenido fama hasta entonces, allí se la ganaron; procuraron rodearse de toda suerte de prestigios para brillar en aquella turbamulta de pasiones. La mayoría de los bailarines estaba constituida (sic.) por marineros, conductores de vehículos, de tropas de caballo, como las de Langanay y otras, que lucían el pantalón corto de los jinetes de la épica y calzaban alpargatas adornadas por un gran moño colorado en la parte superior. Gente de averías, que no tenían

32 Héctor y Luis J. Bates, Historia del Tango (Buenos Aires: Talleres Gráficos de la Compañía General Fabril Financiera, 1936), 28. 
inconveniente ni recelo ninguno en certificar su condición de guapa, ya que por cualquier circunstancia se trenzaban en singular duelo de arma blanca, arma que era complemento indispensable de su vestimenta, de su trabajo y de su idiosincrasia.... ${ }^{33}$

No hablan los Bates en concreto del compadrito sino de las figuras masculinas en general que acudían a los lugares de baile. Hablan en general de gente guapa y pertenecería a lo que Jorge Luis Borges llamó secta del cuchillo y del coraje. Serían protagonistas de peleas y duelos - siempre valientes, en opinión de Borges - y emplearán la danza como un medio para mostrar sus habilidades y una más de las cualidades por las que la gente de una u otra manera los admiraba. Nos ocuparemos más adelante del análisis de estas figuras en el tercer capítulo de nuestro trabajo ${ }^{34}$ así que no nos detenemos demasiado en su descripción para poder añadir otros ingredientes a este interesante relato.

Los Hermanos Bates defienden que el tango nació en los peringundines o trinquetes, y que ésa es la razón por la que la sociedad porteña no aceptó en un primer momento esta danza. Eran lugares en los que mujeres "de vida aireada" empleaban el baile para atraer a jóvenes porteños que buscaban divertirse. Nombran también, como lugares de baile, las casas de citas.

A diferencia de los hermanos Bates y su defensa del triple origen del tango, Carlos Vega presenta como Las especies progenitoras del tango las siguientes: el lundú —danza brasileña cuyo origen podría remontarse a 1750 aproximadamente-, la milonga y el tango español. Por otro lado, Vicente Rossi hablaba de la milonga montevideana como la madre del tango actual. Debemos recordar que Rossi publica Cosas de Negros en el año 1926, es decir, diez años antes de la publicación del trabajo de los Bates. También Carlos Vega rechaza ese origen arrabalero del tango que lo sitúa en las clases más empobrecidas. Literalmente dice: «El tango fue elaborado en los lugares

33 Ibidem, 29.

${ }^{34}$ En el subcapítulo 3.1 de este trabajo se analizan los roles de género masculino que se configuraron a lo largo del siglo XIX y que remedan aún en la actualidad muchos bailarines de tango. 
donde se bailaba por dos generaciones de bailarines». ${ }^{35}$ Es decir, no pone el foco en el arrabal, sino en los lugares donde se bailaba, sitios en los que se encontrarán «juntos y hermanados los bailarines de la aristocracia, los de la clase media, los de las clases menores, los malevos, los orilleros, los compadritos... - repetimos_ los bailarines». ${ }^{36}$ Lo que sí afirma Vega es que los que crearon el tango fueron los hombres, los varones. De cualquier estrato y condición social, sí, pero varones. Eso sí, las mujeres que bailaban con ellos, sus compañeras, pertenecían casi exclusivamente a las clases más desfavorecidas y, de manera excepcional, a las clases medias.

En todo caso, y salvo excepciones como la de Carlos Vega, la hipótesis del nacimiento del tango en los bajos fondos rioplatenses es algo común a todos esos autores que siguen la línea de lo que aquí hemos llamado "relato clásico". Otro ejemplo serían los trabajos de Javier Barreiro:

«Una brillante generación de libertinos porteños creó el tango, en cuanto danza, en colaboración con las mujeres de la noche. Yo no elogio la conducta social de esa ilustre generación de libertinos bravos; pero los intereses eternos de la danza no escogen a sus propulsores entre los virtuosos, porque les importan los creadores». ${ }^{37}$

Un ingrediente más en la creación de esta leyenda fueron las letras de las primeras milongas. Para hablar de ellas nos vamos a referir al trabajo de Javier Barreiro titulado El tango hasta Gardel donde consta la cita que acabamos de referir y donde también encontramos un capítulo dedicado a estas letras prostibularias. Convenimos con Barreiro -lo decía también Borges- en que los primeros tangos eran más vitalistas que los posteriores englobados en lo que se conoce como Tango canción. Estas primeras letras fueron transmitidas de manera oral $\mathrm{y}$, como ha sucedido históricamente con la música popular en general, la mayoría no fueron editadas. Sucede también

35 Carlos Vega, Estudios para los orígenes del tango argentino (Buenos Aires: Universidad Católica Argentina. Instituto de Investigación Musicológica Carlos Vega, 2016), 118, acceso el 23 de abril de 2021, http://bibliotecadigital.uca.edu.ar/repositorio/libros/origenes-tango-argentino-vega.pdf.

${ }^{36}$ Ibidem, 128.

37 Javier Barreiro. El tango hasta Gardel (Zaragoza: Ed. Diputación provincial de Zaragoza, 1986), 49. 
que el carácter popular del género, al menos en sus primeros años, explica que puedan aparecer dos o más letras diferentes de una misma canción. En todo caso, los ejemplos que vamos a presentar se pueden encontrar en todos los estudios de tango que hemos consultado hasta el momento y se pueden considerar comúnmente aceptados por todos. Eran letras en su mayoría con doble sentido que aludían a cuestiones de índole sexual y mal vistas entre la parte de la sociedad que se decía decente. Por este motivo muchas veces eran, como hemos dicho anteriormente, camufladas bajo otras palabras mejor aceptadas. Gustavo Varela apunta que este momento coincide con el nacimiento de un discurso sobre la sexualidad del que hablaremos más adelante. Los Bates nos hablan también acerca de cómo se había supuesto erróneamente que los primeros tangos no habían tenido letra a lo que ellos se oponen firmemente afirmando que quienes defendían esa idea simplemente no conocían esas letras, lo que podría resultar lógico — según los Bates- si atendemos al siguiente argumento:

«...si la música es un reflejo del ambiente y la letra siempre o casi siempre trata de pintarlo, se convendrá con nosotros que los antiguos temas no han podido trascender y llegar hasta los días actuales. El tango vivió su infancia y buena parte de su pubertad — permítasenos la expresión- en casas de baile de muy segundo orden, en "peringundines" y lupanares. Las letras no hicieron nada más que reflejar el ambiente que les daba vida. Obscenas, procaces, indecibles en un medio, no diremos ya de cultura o de hogar, sino aun en boca de personas de cierta educación, quedaron circunscriptas a los muros que ocultaban la vergüenza de la ciudad $» .^{38}$

Es curioso cómo incluso los autores no se atreven a transcribir en su estudio letras de tangos antiguos si no es con algún "retoque" para no escribir lo que realmente decían. De hecho, se alegran de que esos tangos fruto de "la obscenidad y la estulticia" desaparecieran a comienzos del siglo XX y comenzara una nueva era con tangos como La morocha o El apache argentino.

${ }^{38}$ Héctor y Luis J. Bates, Historia del Tango (Buenos Aires: Tall. Graf. De la Cía general fabril financiera, 1936), 75. 
En un espacio posterior dedicado específicamente a la masculinidad en el tango analizaremos las letras de una amplia selección de tangos ${ }^{39}$, así que no nos detendremos ahora nada más que para mostrar algunos de los títulos a los que hemos hecho ya referencia y que se conocen como tangos procaces: El 69, Dos sin sacarla, El fierrazo, El Choclo o La c...ara de la I...una.

Debemos aclarar que, aunque nos refiramos continuamente a la Historia de los hermanos Bates, esta línea de investigación la siguieron autores posteriores actualizando algunos puntos. En lo que a este trabajo respecta, no interesa diferenciar los trabajos y los pequeños matices que puede haber entre ellos, sino que para nosotros hablar de los Bates es describir toda una corriente de opiniones y estudios que van por un mismo camino: la defensa del origen arrabalero, negro y prostibulario del tango. En esta línea incluiríamos a autores como Javier Barreiro —cuyo trabajo El tango hasta Gardel es prácticamente una réplica del trabajo de los Bates-, Roberto Selles, Jorge Ribera o León Benarós, así como, en ciertos aspectos, a sus antecesores como Carlos Vega, Vicente Rossi o Lauro Ayestarán.

Siguiendo entonces la línea de los hermanos Bates vemos cómo —en su opinión-esta maravillosa evolución del tango desde los arrabales canallas e indecentes hasta los grandes salones parisinos «desenmascaró a esa sociedad mojigata» ${ }^{40}$ del Río de la Plata. Hemos escuchado a lo largo de las últimas décadas cómo el tango arrabalero era mal visto - por las razones que hemos expuesto- entre las que en ese momento se conocían como las clases altas de la sociedad. Sin embargo, nos cuentan que pocos años antes del comienzo de la Gran Guerra el tango viaja a París donde enamora al público que tiene la oportunidad de conocerlo y desde donde se daría a conocer en todo el mundo. Eso sí, adecentando su coreografía eliminando, por ejemplo, sus clásicos cortes y quebradas. Esta es la maravillosa evolución de la que hablan los Bates, aunque lo cierto es que su Historia del Tango está

${ }^{39}$ Véase capítulo 3, apartado 3.2.2 de este trabajo, «La masculinidad en las letras del tango rioplatense» dentro del subcapítulo «La masculinidad en el lenguaje».

40 Héctor y Luis J. Bates, Historia del Tango (Buenos Aires: Tall. Graf. De la Cía general fabril financiera, 1936), 31. 
llena de anécdotas y opiniones con muy pocos documentos que sostengan sus teorías. Es verdaderamente interesante comprobar cómo fue capaz de construirse en torno a ella esto de lo que seguimos hablando a continuación y que hemos querido llamar el relato clásico.

Nos interesa mucho la descripción que Barreiro -aparece también en la historia de los Bates, quienes sin ninguna duda fueron un referente fundamental para él一 hace de la aparición de la milonga. Su relato es que el compadrito veía los bailes de los negros, aunque no participaba en ellos. Estas danzas serían algo exótico para él, por lo que empieza a imitar sus movimientos exagerando en tono de burla los cortes y las quebradas. Estos movimientos los incluiría en la música de su entorno y particularmente en la milonga. Este sería, por tanto, el precedente coreográfico del tango. El texto de Barreiro es prácticamente el mismo que podemos leer en el segundo tomo de La Historia del Tango editada por Corregidor en 1977 escrito por León Benarós y Roberto Selles. Al hablar del origen de la milonga nos remite también al texto de Ventura Lynch La provincia de Buenos Aires hasta la definición de la cuestión Capital. Suponemos que Lynch fue uno de los autores de referencia para los hermanos Bates a la hora de escribir su historia.

También nos habla Barreiro de esas parejas de hombres bailando tango a las que se refería, entre otros, Evaristo Carriego en su poema «El alma del suburbio», de quien hablaremos en el capítulo dedicado a la literatura. Se ha hablado muchas veces de este mito de las parejas de hombres bailando, pero desde la historia de los Bates ya se aclara que ese hecho no tenía ninguna connotación homosexual, sino que los hombres se juntaban entre ellos para practicar en las calles puesto que era de gran importancia mostrar sus habilidades con el baile. Encontramos sin embargo una afirmación de Vicente Gesualdo donde asegura que existían lugares -el bailetín del Palomar, por ejemplo- donde exclusivamente se bailaba tango entre hombres. ${ }^{41}$ Según nos cuenta Gesualdo en estos lugares las mujeres no bailaban, sólo compartían bebidas con los vecinos. El tango, tanto en su

${ }^{41}$ Vicente Gesualdo, La Música en la Argentina (Buenos Aires: Editorial Stella, 1988), 
faceta coreográfica como cantado, contiene en esta época una gran habilidad improvisatoria, lo que podría remontarse a los payadores y guitarreros que acostumbraban a improvisar coplas a menudo. Por ello, no es de extrañar que los hombres se pusieran a bailar en cualquier momento, lugar, y con cualquiera que se prestara a ello.

Para finalizar este resumen del relato clásico acerca de los primeros años del tango debemos detenernos en los lugares donde - se suponía hasta hace unos años- se practicaba con mayor frecuencia. Hemos hablado ya del tango en la calle, entre hombres, aunque también podría unirse a la fiesta una mujer. Suponemos que esto no sería tan habitual, pero es relevante destacar que sucedía. Así lo reflejaría -en la opinión de Benarós y posteriormente de Barreiro- este poema de Aníbal Marc Giménez escrito en 1904:

«El silencio del suburbio se interrumpe de repente por la voz de un organillo que inicia un tango sensual, y el compadrito que pasa con el chambergo en la frente hace ondular las caderas en un corte magistral.

Y de pronto ve a la mina; la llama amorosamente y ésta responde al reclamo con un gesto sin igual, en tanto que los curiosos forman rueda velozmente deshojando mil cumplidos en su jerga de arrabal.

$Y$ entre guarangos decires que pican como alfileres se ponen como amapolas las caras de las mujeres y un cosquilloso hormigueo sienten bajo de la piel.

Mientras la esbelta muchacha, en voluptuosas quebradas, va barriendo con el ruedo de sus polleras planchadas el polvo fino asentado en medio del redondel». ${ }^{42}$

42 Roberto Selles y León Benarós, La Historia del Tango. Vol. 2, (Buenos Aires: Ed. Corregidor, 1977). 
Desde la calle el tango —o, mejor dicho, la milonga — se trasladará a los locales donde en esos años se bailaba. La historia nos habla de academias, conventillos, peringundines, cafés y casas de citas.

La más antigua ubicación a la que se refieren los estudios sitúa los primeros tangos bailados en las romerías españolas que fueron los primigenios lugares donde hombre y mujer bailaron juntos. Se celebraban en carpas al aire libre y no faltaban en ellas los duelos criollos, según nos describen los Hermanos Bates:

"Los duelos criollos eran tan comunes que, ya al final, no llegaron a preocupar a los demás, demasiado atareados en rendirle pleitesía al tango que ya comenzaba a "entrar". No eran extraños al ambiente, tampoco, algunos duelos realizados entre dos o más bailarines que se habían desafiado previamente a ver cuál era más habilidoso para la danza. Y como no se convencían con las demostraciones realizadas, no encontraban nada mejor que dirimir la cuestión coreográfica a fuerza de tajos». ${ }^{43}$

Éste podría haber sido perfectamente el punto de partida de la leyenda -o historia- acerca del origen del tango, fiestas populares en las que los vecinos y las familias se divierten y donde poco a poco se incluyen pasos, movimientos y gestos nuevos. Sería la época — supuestamente- del tango canyengue que analizaremos más adelante al hablar de las diferentes maneras de afrontar la danza del tango ${ }^{44}$.

A continuación, voy a describir brevemente los locales en los que, según este primer relato, se bailaba esta danza. Ya hemos dicho en páginas anteriores que también el tema de dónde y en qué condiciones se bailaba el tango se convirtió en fuente de controversia con la aparición de las nuevas teorías.

Según Vicente Rossi -a quienes posteriores autores como León Benarós u Horacio Salas se referirán en estudios más modernos- las academias eran salones de bailes públicos. En Montevideo habría más o

${ }^{43}$ Héctor y Luis J. Bates, Historia del Tango (Buenos Aires: Tall. Graf. De la Cía general fabril financiera, 1936), 35.

${ }^{44}$ Véase el apartado 3.3.2.1. titulado «El tango canyengue». 
menos una por barrio. Destaca como las más duraderas San Felipe y Solís y Gloria. Se preocupa Rossi de distinguirlos como verdaderos lugares donde se bailaba por que no fueran confundidos con otros en los que «utilizaban la danza como antesala del libertinaje, no haciendo de ella una especialidad sinó (sic) un medio». ${ }^{45}$ Deja claro que la finalidad de las academias y de los criollos que las frecuentaban era lucir sus dotes de bailarines negando cualquier ápice de sensualidad en la danza. Destaca como el ejemplo más típico la academia San Felipe:

«el más típico y amplio, el mas (sic) importante y famoso, el creador de la academia del corte y la quebrada, el clásico; el mas (sic) cómodo pues ofrecía al público amplia gradería de tablas, alta y baja». ${ }^{46}$

Según León Benarós, en Buenos Aires la academia, como centro en el que se aprendía a bailar tango, tenía algún rasgo que la distinguía de la montevideana, a pesar de tener muchos rasgos en común sobre todo en sus orígenes.

Horacio Salas sitúa el origen de las academias - asociadas por primera vez al tango en un artículo de 1903 del que hablaremos con más detenimiento en páginas posteriores- en el año 1870 y nos cuenta lo siguiente acerca de sus bailarinas habituales:

«En esos salones era posible encontrar mostrando sus habilidades a algunas de las más famosas bailarinas de fin de siglo: la Parda Refucilo, Pepa, la Chata, Lola la Petisa, la Mondonguito, la China Venicia y María la Terom. ${ }^{47}$

Después de leer los textos a los que nos hemos referido líneas arriba y algunos más que hemos consultado para este estudio, la línea que separa los lugares donde estrictamente se bailaba para aprender y donde esta actividad se mezclaba con otras de índole sexual es muy fina. En todo caso, parece que el fin último de una academia era aprender a bailar, entre otras danzas, el tango. Había bailarinas fijas con quienes los hombres practicaban la danza.

\footnotetext{
${ }^{45}$ Vicente Rossi, Cosas de negros (Buenos Aires: Hachette, 1958), 129.

46 Ibidem, 132.

${ }^{47}$ Horacio Salas, El tango, 4ª ed (Buenos Aires: Ed. Planeta, 1999), 79.
} 
Nos llama la atención, además, que los hermanos Bates no nombren este lugar de baile en su Historia del Tango.

Las casas de baile, según Javier Barreiro, eran casas particulares que se alquilaban a grupos de personas que se reunían por la noche. Las más famosas en la leyenda tanguera serán las de Laura (Laura Montserrat) y María la Vasca (María Rangolla), aunque había muchas más ${ }^{48}$. Lo de María la Vasca era un lugar más popular donde se ofrecían mujeres para bailar a tres pesos la hora. El marido de la Vasca vigilaba atentamente que nadie traspasara los límites de la decencia. Allí tocaron músicos tan relevantes como Vicente Greco.

A Lo de Laura acudía gente de más alta cuna, señores que además de bailar tenían una querida o amante entre las mujeres que ofrecía el lugar para "bailar". La propia Laura parece que hacía ostentación tanto de riquezas como de relaciones sociales.

Carlos Vega nos habla también de las Casitas, casas de menor tamaño que un grupo de estudiantes sostenían y que ponían a cargo de una mujer que se encargaba además de invitar a varias mujeres «desinteresadas y libres». ${ }^{49}$

Entre los cafés el más famoso fue el conocido como Lo de Hansen y estaba rodeado de otros muchos como El Velódromo, El Pasatiempo, El Pabellón de las Rosas, El recreo del Pobre Diablo o La Red. A todo este entramado de cafés León Benarós lo llamará "Hansen y compañía", lo que nos induciría a pensar que serían locales de similares características. Lo de Hansen se llamó en un principio Café Tarana y estaba situado en el barrio Palermo. Parece que abrió sus puertas en 1875 y después de la muerte de Hansen —su primer concesionario de origen alemán-conservó su nombre y se forjó una leyenda en el mundo del tango. Parece que era un local en el que por la noche se podían escuchar grupos de música interpretando, entre otras

48 Javier Barreiro. El tango hasta Gardel (Zaragoza: Ed. Diputación provincial de Zaragoza, 1986), 37.

49 Carlos Vega. Estudios para los orígenes del tango argentino (Buenos Aires: Universidad Católica Argentina. Instituto de Investigación Musicológica "Carlos Vega", 2016), acceso el 31 de octubre de 2020, http://bibliotecadigital.uca.edu.ar/repositorio/libros/origenestango-argentino-vega.pdf. 
músicas de la época, tango. Sin embargo, existe una polémica - como parece suceder con todo lo que tiene que ver con esta época- acerca de si se bailaba o no en Hansen. León Benarós muestra en su Historia del Tango los testimonios de Amadeo Lastra y Roberto Firpo en los que afirman terminantemente que en "Lo de Hansen" no se bailaba.

«Parece que en estas glorietas de Palermo se llegaron a producir gran cantidad de incidentes debido a que este lugar fue punto de encuentro entre la gente de las orillas y los jóvenes de la élite porteña. Uno especialmente relevante fue aquél en el que perdió la vida Juan Carlos Argerich a manos de "Cielito Traverso", hombre del General Roca. Parece ser que por casos como este la gente que acudía a estas zonas de la ciudad a divertirse dejó de hacerlo hasta que poco a poco los locales fueron desapareciendo. El tango se trasladaría a la orilla del Riachuelo». ${ }^{50}$

Hablemos ahora de uno de los emblemas de la ciudad de Buenos Aires: los conventillos, también conocidos como inquilinatos. Estas peculiares edificaciones contenían viviendas comunes que compartían inmigrantes de todas las procedencias. Eran estancias construidas en torno a un patio en las que solía vivir una familia completa, aunque a veces el dueño permitía meter en una sola estancia a un grupo de hombres. Así los describe León Benarós:

«Las innumerables piezas chiquitas se alineaban a lo largo de un patio inmenso. Eran, por lo común, de madera, bajitas y oscuras. A cada pieza solía corresponder una cocinita, especie de garita de vigilante, diminuta e incómoda, o bien la franca cocina a carbón, oscura de hollín, que llenaba de humo, sumándose a otras, el claro cielo que aún podía verse en aquel infierno. Los braseros de trípode, petisos y redondos, con dos argollas como aros de negro se veían también y en muchos inviernos daban una muerte dulce, en el descuido de los desprendimientos de gas carbónico, cuando el frío apretaba y se cerraban las puertas sin advertir el peligro. No faltaba el loro compañero

156.

${ }^{50}$ Vicente Gesualdo, La Música en la Argentina (Buenos Aires: Editorial Stella, 1988), 
de desgracia de aquel mundo cruel y abigarrado. Tenía su trono sobre un soporte erizado de estacas laterales, que le servían de escalera». ${ }^{51}$

En este ambiente parece ser que no era bien visto el tango. Estamos ya en un ámbito privado, no es la calle, no es un prostíbulo ni una academia, es el hogar familiar. Especialmente los hombres querían evitar que lo que viniera del ambiente arrabalero - ya fuese el tango, ya el compadre- interfiriera en la moral familiar que tanto intentaban preservar. Según Horacio Salas lo que sucedió fue que el tango se fue introduciendo poco a poco. Al principio las mujeres no querían bailarlo, las jóvenes lo evitaban delante de sus padres, pero finalmente claudicaron adecentando ligeramente los movimientos coreográficos. Podría considerarse el conventillo un paso intermedio entre el tango del arrabal y el tango de la clase media ${ }^{52}$.

León Benarós establece un orden al hablar de los lugares de baile. Como punto de partida estarían las romerías españolas. De ahí el tango pasaría a desarrollarse en peringundines y trinquetes para pasar, posteriormente a los conventillos, los salones y el cabaret. Como ya se ha dicho, Salas establece el conventillo como paso previo a los salones de la clase media. Carlos Vega nos habla también de las esquinas como lugares donde los hombres ensayaban y destaca que "los ensayos callejeros de baile son casi tan antiguos como los organitos ambulantes" 53 .

En cuanto a los peringundines, bailetines, bailongos y demás denominaciones se puede afirmar que salvo leves diferencias eran lugares similares donde se iba a bailar. Podrían haber sido la antesala del cabaret, otro importantísimo lugar de interpretación de esta música.

En lo que todos coinciden es en que el tango encontró fácilmente un lugar de esparcimiento en el burdel. En los prostíbulos se bailaría tango acompañado de músicos "analfabetos" que tocarían de oído los temas

${ }^{51}$ Roberto Selles y León Benarós, La Historia del Tango, vol. 2 (Buenos Aires: Ed. Corregidor, 1977), 236-237.

52 Horacio Salas, El tango, $4^{\mathrm{a}}$ ed., (Buenos Aires: Ed. Planeta, 1999), 86-87.

${ }^{53}$ Carlos Vega. Estudios para los orígenes del tango argentino, (Buenos Aires: Universidad Católica Argentina. Instituto de Investigación Musicológica "Carlos Vega", 2016), acceso el 31 octubre de 2020, http://bibliotecadigital.uca.edu.ar/repositorio/libros/origenestango-argentino-vega.pdf. 
empleando, en un primer momento, flauta, violín y guitarra. Se añadiría más tarde el organillo de manera que llegaría un momento en el que todos los burdeles contaran con un instrumento. Este ambiente da lugar a los famosos tangos prostibularios de los que ya se ha hablado como Dame la lata o El Queco.

Hasta aquí el relato que popularmente se ha transmitido de generación en generación acerca de los orígenes y la vida del tango en sus primeros años. Nosotros lo hemos calificado como clásico porque entendemos que sus aportaciones adquirieron el rango de canónicas especialmente al ser aportadas por investigadores, estudiosos y escritores de muy diferentes épocas.

Efectivamente, después de las lecturas, el análisis exhaustivo de estas fuentes secundarias y la reflexión acerca de esta leyenda tan contada debemos estar de acuerdo con los que afirman que en esta historia no hay documentos suficientes que demuestren las tesis planteadas. Parece un gran conjunto de anécdotas que comienzan a ver la luz a principios del siglo XX y va creciendo hasta que un siglo después alguien se plantea desmentirlas. Pero, en realidad, y como veremos más adelante nadie las desmiente totalmente, sino que plantean objeciones afirmando que no tuvo que ser necesariamente así, ni exactamente allí, ni únicamente con ese tipo de personas. Es decir, no se fían de lo que nos contaron toda la vida, pero tampoco pueden demostrar que todo aquello no existiera. Más bien defienden que quizás esa parte de la historia se mitificó demasiado hasta el punto de afirmar que el tango únicamente se bailaba en los burdeles.

Por último, queremos aclarar que el hecho de que la Historia de los Bates no esté documentada no es óbice para prescindir de sus aportaciones. No tendría sentido pensar que tantos protagonistas del tango y tantos espectadores quisieran contarnos una historia completamente falsa. En este trabajo hemos querido valorar el trabajo de los Bates como la muestra más trabajada de cómo se veía el tango en la década de 1930 que, como veremos, fue fundamental en la configuración de una estética que se vio reflejada particularmente en la danza. La otra razón por la que nos parece relevante 
este texto es que fue el punto de partida de posteriores investigaciones que poco o nada se salieron de la historia tal y como ellos nos la quisieron contar.

2.1.2. Nuevos paradigmas: El tango en la sociedad porteña.

Las principales publicaciones que contienen este relato de alguna $u$ otra manera son, en orden cronológico, las siguientes: El tango en la sociedad porteña de Hugo Lamas y Enrique Binda $(1998)^{54}$, la Tesis Doctoral de Marta Rosalía Norese titulada Contextualización y análisis del tango. Desde los orígenes a la vanguardia. $(2002)^{55}$ y la Nueva Historia del tango. De los orígenes al siglo XXI de Héctor Benedetti (2015) ${ }^{56}$. Además, encontramos numerosos artículos y otro tipo de trabajos como los de María Julia Carozzi ${ }^{57}$, o Ricardo García Blaya ${ }^{58}$ que van por este camino. Ya advertimos en las primeras páginas que la cantidad de artículos y pequeños trabajos sobre tango desde todas las perspectivas es realmente abundante.

De todos estos trabajos quizá el que más nos interesa sea el de Lamas y Binda. Además, es el primero cronológicamente así que lo presentamos como punto de partida y base para todo lo dicho posteriormente. También tenemos que destacarlo por encima de los otros dos por la intención de los autores en el momento de llevar a cabo su trabajo. Mientras la Doctora Norese y Héctor Benedetti intentan abarcar toda la historia del género, desde los orígenes hasta la Vanguardia o hasta el s. XXI, los autores de El tango en la sociedad porteña se centran en los primeros treinta años y destacan su intención de desmentir el mito del tango prostibulario como único en los primeros años.

54 Hugo Lamas y Enrique Binda, El tango en la sociedad porteña. 1880-1920 (Stuttgart: Editorial Abrazos, 2008).

${ }_{55}$ Marta Rosalía Norese, Contextualización y análisis del tango. Sus orígenes hasta la aparición de la vanguardia (Salamanca: Ediciones Universidad de Salamanca, 2002).

56 Héctor Benedetti, Nueva historia del tango. De los orígenes al siglo XXI (Buenos Aires: Siglo Veintiuno editores, 2015).

${ }^{57}$ María Julia Carozzi, Aquí se baila el tango. Una etnografía de las milongas porteñas (Buenos Aires: Siglo veintiuno editores, 2015).

58 Ricardo García Blaya fue el fundador de Todo tango, sitio web que continúa realizando una importante labor de recopilación y registro donde él y muchos autores más a los que aludiremos en nuestro trabajo escribieron interesantes reseñas sobre diferentes aspectos relacionados con el tango. 
El tango en la sociedad porteña parte de la dificultad de que nadie en la actualidad sabe cómo era el tango de los primeros años. Incluso se ven en la necesidad de ofrecer una definición de tango como punto de partida. E tango para ellos es «música popular, bailable y cantable». ${ }^{59}$ En mi opinión, más que una definición esta frase sólo pone de manifiesto que lo único de lo que están seguros es de que el tango se bailaba y se cantaba.

En un primer capítulo los autores pretenden demostrar que el tango era socialmente aceptado ya a finales del siglo XIX. Al decir 'socialmente' se refieren a todas las clases sociales, no sólo a las marginales. Nos presentan por ejemplo dos referencias en las que miembros del ejército y aspirantes a médicos respectivamente ejecutan tango, siendo el ejército y los médicos dos grupos sociales aparentemente ajenos a los ambientes del suburbio ${ }^{60}$. Aseguran también —remitiéndonos a los interesantes trabajos de Tomás de Lara e Inés Leonilda Roncetti de Panti-que el tango aparece en numerosas referencias teatrales y suponen que si aparece en el teatro esto significa que el público lo conocía y lo comprendía. Concluyen a continuación que, si aparecía frecuentemente en el teatro, debía haber referencias en otros lugares. Así explican sus pretensiones:

«Quienes se han dedicado al tema del tango y su origen, usualmente no se interesaron por lo popular sino lo marginal, lo prohibido. En definitiva, aquello históricamente irrelevante por no ser representativo del conjunto de la sociedad. Trataremos de corregir el enfoque, viendo a continuación el aspecto popular de los bailes». ${ }^{61}$

En cuanto a los vocablos tan frecuentes en el relato clásico como 'compadrón', 'compadrito', 'quebrada' o 'milonguero' prefieren obviarlos a no ser que aparezcan seguidos de la palabra tango. Asimismo, aportan algún documento en el que se puede leer el adjetivo compadrón aplicado a otras danzas como la mazurca y la polca. De ello deducen que el término no tendría

59 Hugo Lamas y Enrique Binda, El tango en la sociedad porteña. 1880-1920 (Stuttgart: Editorial Abrazos, 2008), 97.

60 Ibidem, 98 y 104.

61 lbidem, 46. 
un significado tan determinante cuando lo vemos aplicado al tango. Para ellos son cualidades que no se pueden aplicar a un género musical.

La primera gran conclusión de Lamas y Binda sería que el tango era un género ya socialmente conocido a finales del siglo XIX por todas las capas de la sociedad y que no puede ser definido como exclusivo de las clases marginales.

«Haber sido el tango exclusivo de clases bajas o marginales, bailado sólo entre hombres, rechazado por las mujeres decentes en su totalidad, etc., permanece sin demostración». ${ }^{62}$

Insisten los autores en afirmar que el tango no era algo prohibido ni prostibulario, tampoco "cosa de negros". La prueba es que se interpretaba públicamente en teatros y comparsas. Un ejemplo de lo que el relato clásico olvidó mencionar son las bandas de música:

«Ellas han sido poco tenidas en cuenta por ser orquestas sociales. Como a partir de los Bates se han empeñado en referir a lo marginal, surgen así como únicos instrumentos tangueros al darlos como propios de tales ámbitos, la flauta, el arpa y el violín. Se llega al colmo de afirmar que la guitarra, quizá el instrumento de más difusión y fácil aprendizaje, no integraba los primitivos conjuntos». ${ }^{63}$

En el capítulo correspondiente a los primeros años del s. XX Lamas y Binda nos presentan varios fragmentos de crónicas de teatro en los que se describe la presencia no sólo del tango, sino de todo lo criollo. Parece que fue una época en la que empezaba a gustar este tipo de espectáculos.

Lamas y Binda no sólo recogen una gran cantidad de documentación que demuestra que el tango era algo aceptado en todos los estratos sociales del Río de la Plata desde los últimos años del s. XIX, sino que se ocupa de cuestionar las tradicionales teorías acerca del tango. Cuando uno se acerca a esas nuevas teorías o, mejor dicho, al cuestionamiento de las viejas teorías

62 Ibidem, 102.

63 Ibidem, 54. 
se pregunta ¿por qué? ¿no hubo réplica? ¿Nadie desmintió tales falsedades en su tiempo? Nos proponen la siguiente reflexión:

«En primer lugar, las formaciones intelectuales de la época de las crónicas y la actual, son diferentes. En segundo término no se trataba de un tema de carácter político o religioso, en cuyo caso hubiese generado instantáneamente una réplica por afectar determinados intereses o creencias. Finalmente la historiografía no era aún una ciencia, estando aunadas en el criterio general la mitología con la propia historia. No era concebible en el imaginario popular, salir a responder con documentación en mano sobre un tema -el tango-que no era motivo de estudio, sino fuente de esparcimiento». ${ }^{64}$

En cuanto a los lugares donde se bailaba el tango Lamas y Binda desmienten, por ejemplo, que academias y peringundines fueran lugares diferentes. Asimismo, aclaran que en las academias no se aprendía a bailar tango y niegan también la leyenda del tango bailado entre hombres. Lo que ellos dicen no es que no existiese, sino que no era privativo del tango. En cuanto al tango bailado entre hombres dejamos nuestras consideraciones para más adelante por haber un espacio concreto en este trabajo para tratar este tema.

Con respecto a las letras de tango nos parecen interesantes dos trabajos sobre música folclórica que también nombran Lamas y Binda. Se trata de los trabajos de Lehman Nitsche ${ }^{65}$, en concreto uno titulado Antrohopopyteia de 1923 que recopila textos eróticos del Río de la Plata. De los textos recopilados por Nitsche únicamente cuatro son tangos. Este hecho apoyaría la idea de los autores de que no existe relación demostrada entre letras eróticas y origen prostibulario del tango. Además, son temas que se relacionan también con la música folclórica, así que no serían exclusivos del tango. Concretamente dicen:

64 Ibidem, 189.

65 Robert Lehmann-Nitsche fue un antropólogo y médico alemán que, desde 1897 trabajó en el Museo de la Plata, museo de ciencias naturales, arqueología y etnografía más grande de Argentina. Trabajó también en la Academia Nacional de Bellas Artes de Buenos Aires e integró una importante red científica dedicada a temas como el folclore, la lingüística o la mitología. 
«En resumen, nos interesa demostrar que si eventualmente, como parte de un fenómeno difundido en otros géneros musicales y lugares, se cantaban tangos con letras subidas de tono incluso en los prostíbulos, no convalida suponer que él nació, se desarrolló y permaneció recluido en ellos. Tampoco que no haya podido salir de este ámbito hasta perder su condición de prohibido, recién cuando se produjo su consagración en París, a los albores de la Primera Guerra». ${ }^{66}$

Creo que en esta cita Lamas y Binda resumen perfectamente el nuevo relato acerca de los orígenes del tango. Ninguna de las tesis clásicas es sostenible ni con documentos ni con el sentido común. Se trata de un cuento que se ha ido construyendo a base de anécdotas pero que adquirió tanta fuerza que las primeras teorías acabarían siendo canónicas. Sin embargo, como ya hemos apuntado, tampoco existe base documental ni de otro tipo que nos permita afirmar que entre todas las personas que relataron esta historia —especialmente los protagonistas - haya existido una especie de acuerdo tácito para exagerar o fabular alrededor del tango.

Marta Rosalía Norese en su Tesis Doctoral nos propone una serie de razones que darían lugar a todas las confusiones históricas de las que estamos hablando:

«Algunos estudiosos - Lynch, en el siglo XIX hasta Vega y Ayestarán, pasando por Rossi- habían estado inmersos en el fenómeno y no tomaron debida distancia para el análisis. El resto de los interesados en el tema a) habían sido parte interesada: músicos, poetas, bailarines, o b) habían vivido y compartido su época y toman partido, se sienten implicados para bien o para mal, y ni siquiera intentan el estudio desapasionado». ${ }^{67}$

Esta afirmación de Norese en nuestra opinión no tiene fundamento, puesto que el hecho de ser parte interesada no es óbice para inventarse una historia paralela a la que ellos han vivido. Alguien se puede apasionar al contar una anécdota, pero crear toda la historia de un género es algo más profundo

66 Hugo Lamas y Enrique Binda, El tango en la sociedad porteña. 1880-1920 (Stuttgart: Editorial Abrazos, 2008), 122.

${ }^{67}$ Marta Rosalía Norese, Contextualización y análisis del tango argentino. Desde los orígenes hasta la vanguardia (Salamanca: Ediciones Universidad de Salamanca, 2002), 22. 
y requiere, por lo menos, de una clara intención. Encontramos también en su tesis varios motivos que nos llevarían —al igual que con los aportados por Lamas y Binda- a dudar del relato clásico:

«Encontramos que todos estamos de acuerdo en que hay un período de gestación, que aproximadamente debe darse en las dos últimas décadas de 1800. Pero no sabemos cómo sucede. El tango es música prohibida, no hay casa honesta que lo permita en su seno, se dice. Sin embargo, la industria editorial, de instrumentos, de organitos, la importación de pianos y bandoneones, a más de los salones de baile vive del tango ya a mediados de la primera década de 1900. Se vive de una música prostibularia, de una danza cuya lubricidad asquea a los honestos, pero se la lleva al exterior y allí triunfa? (sic) Para los festejos del Centenario ante lo más granado de la sociedad nacional e internacional se ejecuta un tango en honor del Centenario y se le hace el obsequio a la Infanta de España que nos visita de una partitura de tango ('La Infanta') ¿escrita para ella? ¿Es que se quería ofenderla? Y por el estilo mucho más». ${ }^{68}$

De esta cita podemos decir que los sectores de la industria de los que nos habla trabajan con el tango alrededor de 1905, los festejos del Centenario se sitúan en 1910, así que el Tango que llamamos prostibulario puede haber sido en ese momento superado socialmente y que ya los niños bien llevaban años participando de los bailes de los suburbios. De hecho, existe un artículo de 1903 al que ya hemos aludido al hablar de los lugares de baile, donde se habla ya del tango y su ambiente como algo establecido, y del tango prostibulario como un subgénero superado. Podemos discutir en las fechas, pero igual que los que aquí consideramos representantes de la visión más moderna dudan de lo escrito por falta de pruebas, tampoco a nosotros nos convencen sus argumentos. No decimos que no podría haber sucedido así, sino que no se puede quedar como una cuestión de subjetividades: es que no hay argumentos de peso que refuercen cada uno de los argumentos.

También alude la Dra. Norese en su tesis al hecho de que el tango se grababa en discos y esto costaba dinero, por lo que la gente que lo consumía

68 Ibidem. 
no podía ser pobre. En todo caso y aunque fuera cierto, el tango comienza a grabarse en discos en 1901. Insistimos, si como dice también esta tesis todos estamos de acuerdo en situar los orígenes del tango alrededor de 1880, en 1901 habrían transcurrido más de 20 años de tango en los suburbios.

En este momento de nuestra investigación creemos que queda clara la posibilidad de cuestionar razonadamente la narración tradicional sobre el tango, pero queda claro que sin un análisis de la sociedad y un punto de vista más general de lo que sucedía no podremos entender cómo el tango consiguió ser universal. Antes de mostrar algún estudio más al respecto que complete esta visión nueva de su historia daremos nuestra opinión acerca del trabajo de Lamas y Binda como lo hemos hecho con el de Marta Norese.

En cuanto a Lamas y Binda, es admirable su trabajo y la gran cantidad de documentación que aportan, pero su perspectiva nos parece excesivamente empirista y carente de una visión global de la sociedad del momento. Además, si el tango estaba inmerso en la vida cotidiana de manera tan igualitaria con respecto a otras danzas ¿no se le estaría negando ese carisma tan diferente a otros géneros que lo caracteriza? ¿Podría una danza convencional haber creado una leyenda tan particular sin haber estado relacionada con lugares y personas situadas un poco al margen de la sociedad? En nuestra opinión, no. Y uno de los propósitos de nuestro trabajo es aportar una posible interpretación que explique que el tango haya llegado de los suburbios de Buenos Aires o Montevideo a los países nórdicos o a Japón. Sin embargo, el camino que nosotros proponemos no es histórico ni político, sino estético.

María Julia Carozzi en su libro Aquí se baila el tango hace un recorrido por los estudios de tango a lo largo de la historia desde el punto de vista de las Ciencias Sociales. Nos interesa especialmente la referencia a Nuestra América de Carlos Octavio Bunge y Orígenes de la música argentina de Juan Álvarez en los que — según nos dice la autora- «se presentan las primeras 
versiones racializadas y moralizantes del baile, imaginándole un pasado ora negro ora criollo y pendenciero». ${ }^{69}$

Alude también Carozzi al artículo titulado «Paseos fotográficos por el municipio: el tango criollo» publicado en 1903 en Caras y Caretas. $^{70}$ Es interesante leer en este artículo una especie de compilación de todas las ideas que componen el relato clásico. Nos habla del tango como una mezcla de habanera y milonga, de un tango plebeyo protagonizado por compadritos; y habla de todo ello como algo pasado. Según este artículo, en 1903 el tango de compadritos había desaparecido ya y describe esa etapa como una época clásica que sitúa en Alto y Balvanera. Lo muestra como un género en decadencia. En el momento en el que escribe ya sólo quedarían imitaciones en las veredas de los conventillos que nada tendrán que ver con la gran época de ese baile. Sería solo un mero entretenimiento de la juventud. También alude a los Podestá ${ }^{71}$ como los únicos que lo mantienen vivo y suponemos que esto sucede en el teatro. No termina ahí este asombroso resumen temprano de la historia del tango. En las últimas líneas presenta una visión de futuro y una esperanza en los salones de París, donde parece ser que el tango está de moda y esto podría servir para ofrecerle una nueva vida. Todos estos argumentos se acompañan en la revista por fotografías de un famoso bailarín, Arturo Navas, bailando con otro hombre. Encontramos pues - como apunta también Carozzi- todos los ingredientes que pudieron servir de base para ese relato pendenciero que protagonizó el tango durante tantos años. Recordamos que el texto de Caras y Caretas es de 1903, el artículo de El Viejo Tanguero es de 1913 y la Historia de los Bates se publicó en 1936. ¿Podría haber sido este artículo un punto de partida para la creación de la leyenda? No es el objetivo de nuestro trabajo responder a esta pregunta, pero desde luego se presenta como un propósito interesante.

${ }^{69}$ María Julia Carozzi, Aquí se baila el tango (Buenos Aires: Siglo Veintiuno Editores, 2015), 61-62.

70 «Paseos fotográficos por el municipio: el tango criollo», Caras y caretas, 227 (1903).

71 Los hermanos Podestá fueron una familia de actores de formación circense a quienes se les atribuye la renovación del teatro rioplatense, sobre todo en lo que tiene que ver con la creación de un nuevo modelo de actor. 


\subsubsection{Enfoque sociopolítico.}

El profesor Gustavo Varela presenta su Tesis de doctorado Regularidades y rupturas: un análisis genealógico de la historia del tango argentino en el año 2014 y en su propuesta encontramos un enfoque semejante al que el escritor y estudioso del tango Blas Matamoro ya planteaba en el año 1969 en su texto La ciudad del tango. ${ }^{72}$

El enfoque de Varela se basa en dos ideas fundamentales: la perspectiva genealógica de análisis que propusieron primero Nietzsche y después Foucault y el estudio de las diferentes etapas del tango como períodos singulares estrechamente relacionados con las circunstancias sociales y políticas en las que emergieron. Además, hay un concepto importante en su trabajo, el de las discontinuidades. Varela entiende la historia del tango como un camino lleno de rupturas cuyos detonantes intenta siempre relacionar con el momento social en el que se producen. Estas rupturas, muchas veces bruscas, tienen como consecuencia que se sucedan períodos regidos por paradigmas muy diferentes. Ponemos como ejemplo, por nombrar alguno, el cambio radical que sufre el tango en los años 20, con el éxito del nuevo tango en forma de canción. Así, recorre en su estudio las circunstancias sociales y políticas que rodearon el Tango Prostibulario, el Tango canción y el Tango de Vanguardia. A nosotros nos interesa -además del enfoque del trabajo- lo que aporta acerca del tango prostibulario que sería la etapa que en la que nos centramos como punto de partida en este estudio. En su Introducción podemos leer:

«El tango prostibulario está tratado aquí a partir de un doble proceso relativo al programa modernizador que vive en la Argentina en el último tercio del s. XIX: la emergencia de un discurso sobre la sexualidad, contemporánea a la proliferación de prostíbulos en Buenos Aires, y los cambios en la estructura económico-social, como consecuencia del incremento de población que trae

72 Blas Matamoro, La ciudad del tango. Tango histórico y sociedad (Buenos Aires: Editorial Galerna, 1969). 
la inmigración masiva. El nacimiento del tango se inscribe como práctica singular articulado a este doble proceso». ${ }^{73}$

Otro tema importante en el trabajo de Varela es la sexualidad y encontramos que la alusión a la emergencia de un discurso sobre su manifestación social estaría directamente relacionada con la masculinidad de la que hablamos nosotros. Podríamos considerarlo un elemento más que ayuda a configurar esa sexualidad subjetiva. $Y$ para realizar esta afirmación nos apoyamos de nuevo en una referencia a su texto:

«El aumento exponencial de la cantidad de habitantes producto de la inmigración masiva, el hecho de que hubiera una mayoría de hombres solos, las malas condiciones de vivienda, la pobreza y la marginación, fueron algunas de las condiciones que permitieron que Buenos Aires se convirtiera, en muy pocos años, en uno de los puertos principales para el comercio sexual y la trata de blancas». ${ }^{74}$

Este ambiente que describe Varela está protagonizado por esos "hombre solos" y sus descendientes — quizá más estos últimos- que crearán una serie de gestos, tópicos, actitudes y modos de vestir que configurarán su masculinidad, y ésta se verá directamente volcada en el tango de la época y en el de etapas posteriores.

En cuanto a su enfoque filosófico basado en los textos de Nietzsche y Foucault nos encontramos con una cita que tiene mucho que ver con la idea que sostenemos de que la leyenda creada alrededor del tango quizá no sea válida históricamente pero sí desde un punto de vista estético:

«Si Nietzsche escribió: "La historia de un error: de cómo el mundo verdadero se convirtió en una fábula", el análisis de Foucault es exactamente lo inverso; "La historia de la verdad: de cómo una fábula se convirtió en un mundo verdadero"». ${ }^{75}$

${ }^{73}$ Gustavo Varela, «Regularidades y rupturas: un análisis genealógico de la historia del tango argentino (1880-1968)» (tesis doctoral, Universidad de Buenos Aires, 2014), 12.

$74 \mathrm{lbidem}, 38$.

75 Ibidem, 23. 
Por su parte, Blas Matamoro planteaba a finales de los 60 una visión de la historia del tango centrada en las circunstancias de la ciudad donde se gestó el género. Hace un análisis exhaustivo de la sociedad del momento describiendo sus protagonistas y definiendo cómo estos agentes sociales y sus circunstancias condicionaban el modo en el que se iba modificando el tango en cada etapa. Nos interesa mucho la descripción que hace del gaucho, el compadrito y de todo lo que les rodeaba pero, sobre todo, su enfoque:

«El tango es un fenómeno social, rápidamente clasificable entre la serie de los productos convencionalmente llamados "culturales". Su producción se encara de forma de servir a un público determinado en circunstancias también determinadas. Ello provoca que su estudio implique el de todas las relaciones que se plantean durante el proceso de producción y consumo: vínculo de autor y público, de autor y empresario de producción, de los autores específicos con los maestros de la música formal, etcétera [...] En cada época histórica la materialidad del público cambia, y por lo mismo, el carácter del bien producido y denominado tango (sic.). Por ello es que la ciudad del tango es la ciudad en que han existido los públicos del tango. $Y$ éstos son conglomerados sociales definidos por la totalidad concreta llamada sociedad histórica argentina». ${ }^{76}$

Habla también Matamoro —al igual que lo hará Varela- de las relaciones de poder tan importantes en todos los momentos sociales y de cómo todas las clases sociales no oligárquicas serían relegadas a las orillas en el momento de la constitución de Buenos Aires como capital legal de la Confederación. Esto sucede en 1880, año alrededor del cual se sitúa el nacimiento del tango. La ciudad del tango nos ofrece, por tanto, una visión global de la sociedad en la que emerge el tango y entendiendo ese contexto y a sus protagonistas podremos entender un poco mejor por qué afirmamos que la masculinidad y lo viril fue algo con un gran peso específico en la formación de la coreografía tanguera.

En cuanto a los tipos masculinos que analizamos en nuestro trabajo, los encontramos definidos de la siguiente manera en el libro de Blas 21.

76 Blas Matamoro, La ciudad del tango (Buenos Aires: Editorial Galerna, 1969), 20- 
Matamoro: nos habla del compadre o malevo, del canfinflero o cafisho y del gil o compadrito. En el epígrafe dedicado a la descripción de los roles masculinos de la época compararemos nuestra clasificación con la que acabamos de exponer justificando y explicando los motivos por los cuales escogemos otra distinta.

Con la exposición de estos precedentes académicos queda establecido el marco teórico y más académico que servirá de punto de partida para el desarrollo de nuestro trabajo en lo que a estudios sobre tango se refiere. Ahora es el momento de comentar en qué estado se encuentra actualmente la investigación del tango refiriéndonos a esas fuentes inéditas de las que hablábamos al introducir este capítulo.

La polémica entre quienes defienden el origen prostibulario del tango y sus detractores está tan viva como la existente entre francesistas y uruguayistas al hablar del lugar de nacimiento de Carlos Gardel. Las conclusiones de estas investigaciones aún están por escribirse y damos por hecho que no es una polémica ni mucho menos cerrada y que surgirán nuevos trabajos al respecto y, por qué no, nuevas y desconocidas documentaciones. Uno de los responsables de los últimos estudios sobre el tema es Marcelo Castelo, quien junto a un equipo de investigadores y desde diversos puntos de vista intenta desmentir lo que para él son falacias y mentiras alrededor de la historia del tango. Nos ha parecido no sólo apropiado sino también fundamental incluir sus aportaciones en este trabajo puesto que no podíamos dejar de lado una información muy relevante y actual que tiene que ver con nuestro objeto de estudio.

Marcelo Castelo es uno de los fundadores del Instituto Argentino del tango y creador de la revista Argentango en el año 2005. Aficionado a la historia lleva quince años investigando el tango porque, según nos cuenta, todo lo que le habían contado sobre el tango «no le cerraba» ${ }^{77}$. Además, lleva toda su vida organizando milongas y durante años regentó varias academias

77 Marcelo Castelo, entrevista por Laura Alonso, Alevare, Radiousal, podcast, 9 de febrero de 2021, acceso el 11 de febrero de 2021, https://radio.usal.es/wpcontent/uploads/2015/02/Alevare-09-02-2021.mp3. 
de tango. A pesar de nos ser historiador, por su experiencia y por sus investigaciones nos interesa especialmente lo que nos cuenta sobre la danza, aunque nos gustaría también resumir ahora lo que opina sobre cómo ha sido contada la historia de este género. El objetivo de su investigación es ir encontrando piezas que puedan construir un puzle histórico que tenga sentido y para ello cita casi siempre documentación encontrada por él mismo.

Castelo da por zanjadas las cuestiones relacionadas con el tango prostibulario y la influencia negra en la formación del tango, premisas que desmiente tajantemente. También afirma que en la historia del tango se ha cometido un error de enfoque al considerar sólo el tango en el Río de la Plata sin relacionarlo con lo que sucedía en Europa. Rechaza también el relato acerca de cómo en los años previos a la Primera Guerra Mundial el tango llega a París y tiene lugar el famoso adecentamiento de esta danza. Se basa en imágenes de la época y en representaciones pictóricas de pintores como Monet. Todo lo relacionado con la danza que nos aporta este investigador lo expondremos pormenorizadamente en el tercer capítulo de este trabajo cuando nos ocupemos de describir los diferentes estilos de tango ${ }^{78}$.

En cuanto a los registros de los primeros tangos recordamos que Lamas y Binda proponen un documento de 1888 como el más antiguo en el que existe una referencia al tango. Marcelo Castelo nos habla ahora de artículos periodísticos de 1854 que demuestran que la primera danza enlazada, en dos por cuatro y conocida como tango fue inventada en Francia en 1854. Afirma que, en uno de estos artículos, concretamente de una revista musical, se asegura que esa danza, que llama le tango estaba ya generalizada en las clases populares y que dos años después había llegado a los Estados Unidos. En cuanto al tango en Buenos Aires, los documentos que nos presenta Castelo nos llevan al año 1856 como primera vez que se escribe sobre ese género en territorio porteño.

En definitiva, las investigaciones de Marcelo Castelo siguen el camino abierto por Hugo Lamas y Enrique Binda a finales de los noventa y se

\footnotetext{
${ }^{78}$ Véase apartado 3.3.2, «La masculinidad en los diferentes estilos de tango».
} 
materializará en dos proyectos. Uno junto al bailarín y escritor Pedro Ochoa sobre el cine y el tango entre 1910 y 1914 y un segundo trabajo que versará sobre la enseñanza del tango a comienzos del siglo XX. Este último en colaboración con Rocío Rubio, profesora de tango de Zaragoza afincada en Buenos Aires desde hace muchos años. Además de los que acabamos de nombrar hay una lista más larga de investigadores que actualmente se proponen trabajar en equipo para intentar resolver lo que consideran incongruencias a la hora de hablar de la historia del tango. Son, entre otros, Guillermo Elías, Tito Rivadeneira, Gustavo Lopez Caballín, Roberto Finelli, Gustavo Segú, Martina Iñíguez, Pablo Taboada, Pedro Ochoa y Gustavo Benzecry Saba.

Cuando las conclusiones de las investigaciones en curso sean publicadas tendremos la oportunidad de consultarlos y contrastar los datos con los que ya ofrecieron otros autores previamente. Hasta ese momento lo único que hemos pretendido es dejar constancia de sus aportaciones para así completar el estado de la investigación sobre el tango.

\subsubsection{Una perspectiva coreográfica.}

Decíamos al final del capítulo anterior que nuestro camino comienza una vez que hemos entendido cómo ha sido relatada la historia del tango desde principios del siglo XIX hasta la actualidad.

Nuestro objetivo es demostrar que la masculinidad ha sido un rasgo fundamental en el aspecto sensible de la danza tango, especialmente desde que su historia comenzó a narrarse. Las cualidades que fueron consideradas como propias de los hombres establecen un camino que parte desde los primeros tiempos en los que el tango era una danza popular hasta el siglo XXI, en el que el tango es, además, un espectáculo y un reclamo turístico.

Si hablamos de los tipos sociales masculinos nos interesa especialmente el tipo de hombre que vivió los arrabales rioplatenses, creemos que ahí está el germen estético del tango. Por ello nuestra investigación toma como punto de partida el trabajo coreográfico de uno de los más importantes artistas argentinos en lo que a música folclórica se refiere; un bailarín que, a pesar de 
especializarse en el folclore, se preocuparía también por la danza tango y por conocer sus orígenes.

Como punto de partida y eje de este trabajo presentamos, pues, la propuesta de El Chúcaro, quien fuera también director del Ballet Folclórico Nacional. A través de una trabajada coreografía nos presenta dos de las más relevantes figuras sociales de la historia del Río de la Plata: el gaucho y el compadrito. En su trabajo encontramos al gaucho convirtiéndose en compadrito y el nacimiento del tango como un hecho imbricado en esta evolución. Valiéndonos de su grabación en la televisión argentina del año 1991 analizaremos pormenorizadamente el espectáculo e intentaremos mostrar cómo, según el coreógrafo, los cambios sociales tan importantes sucedidos en esa zona en el siglo XIX condicionaron la historia de este género.

Las tesis que defendemos en este trabajo son dos: por un lado, el poder que lo masculino -refiriéndonos a la masculinidad tal y como se entendía en los primeros años del tango- tuvo en la configuración de la coreografía que observamos aún en la actualidad y, por otro, el canal a través del que esta masculinidad habría llegado hasta nuestros días: el relato clásico de los orígenes del tango. Todo esto está presente en la coreografía de El Chúcaro, por lo que esta creación vertebrará nuestra investigación y nos iremos refiriendo a ella en cada capítulo de nuestro trabajo.

Segundo Santiago Ayala fue, quizás, el bailarín folclórico más importante en la historia argentina. Observando a unos bailarines interpretando un malambo se enamoró de esa música y, en general, de toda la música tradicional que poco a poco fue descubriendo en su tierra, Argentina. Fue un creador incansable y también un estudioso. Intentaba transmitir la importancia de la conservación del folclore, y partiendo de un respeto absoluto a esta parte de su cultura, intentaba también actualizarlo y llegar a otros lugares, artísticamente hablando. Triunfó en otros países de Latinoamérica y también en Europa.

Era un hombre de gran carisma, lo que se apreciaba ya en su aspecto físico, e irradiaba una gran personalidad. Una de las cualidades que se destacaba en él a menudo era la virilidad, tan importante en un hombre nacido 
en la segunda década del s. XX. La revista Folclore en 1962 describía a El Chúcaro de la siguiente manera:

«...-alto, huesudo, de rostro moreno y grandes ojos rasgados, de cabellos lacios y oscuros, de una fuerza expresiva en la faz, que no excluye cierta ensoñativa ternura viril-...». ${ }^{79}$

Nació en Córdoba en 1918. Para entender el modo de pensar y de afrontar la vida de un hombre como Santiago Ayala es imprescindible conocer sus orígenes y la importancia que para él tenía su contacto con el lugar donde se crió. En una entrevista para la misma publicación le describe así su casa a León Benarós:

«Nuestra casa era una casa prestada, un rancho con galería, sostenida por columnas de algarrobo. El techo, de paja y terrón. Dos habitaciones, un horno donde se hacía pan, tortas, empanadas. Una quinta grande, deshabitada, en la que yo aprendí a sembrar maíz y a arar, y en la que cosechábamos melones y sandías». ${ }^{80}$

La música estuvo siempre presente en su hogar puesto que su padre cantaba y tocaba la guitarra y su madre el piano. Asimismo, toda su vida estuvo en contacto de una u otra manera con la vida del campo. De nuevo en la revista Folklore explica cómo la danza era algo inherente a los que allí vivían:

«El hombre de campo nuestro, el legítimo hijo de la tierra, baila instintivamente, pero no sabe que sabe bailar... En él es algo natural. Lo mueve un ritmo, una necesidad de la sangre... ${ }^{81}$

Su primer contacto con el malambo —al menos conscientemente, puesto que él algo ya sabía- fue en la década de $1930^{82}$, cuando vio a un

79 León Benarós, «La vida de "El Chúcaro" contada por él mismo. En diálogos con León Benarós», Folclore, 9 (1962): 6, acceso el 16 de abril de 2021, https://ahira.com.ar/ejemplares/folklore-no-9/

${ }^{80}$ Ibidem.

${ }^{81}$ León Benarós, «Un auténtico creador: "El Chúcaro"», Folclore, 34 (1962), acceso el 16 de abril de 2021, https://ahira.com.ar/ejemplares/folklore-no-34/.

${ }^{82}$ En dos de los artículos consultados en la revista Folklore el Chúcaro da dos fechas diferentes para esta anécdota: 1932 ó 33 y 1937. 
grupo de zapateadores santiagueños bailar encabezados por Luis Colasán. Por aquel entonces Santiago Ayala tenía 19 años y trabajaba como caricaturista para ganarse unos pesos. Días después de ver a estos gauchos del interior bailando fue a pedirle a Colasán que le diera clases. Dos o tres años más tarde empezaba a bailar en un teatro de Córdoba el gato y el malambo con su compañera Irma Rolán. En ese teatro, Gran Guignol, los vio bailar el gaucho Villalba y se los llevó de gira. Fue en esa gira donde le apodaron, sin permiso, El Chúcaro.

Con la misma compañera trabajó unos meses en el teatro Casino de Rosario, donde tuvo que quedarse a vivir por un tiempo. Después de esto, ya terminada la década del 30, Santiago Ayala llega a Buenos Aires. Allí empieza a trabajar fundamentalmente en confiterías $^{83}$ donde, además de bailar malambos, continúa su labor de caricaturista. Poco después en el teatro Maipo participa en dos espectáculos donde interpretaba danzas paraguayas. Después llegaría La Querencia en la avenida de Mayo y el Tabaris donde según él mismo cuenta se inicia realmente su carrera artística:

«...lo demás, fue cosa de cómicos de la legua. Piazza -a quien debo esa oportunidad - , vive actualmente dedicado a fabricar matracas para carnaval. Fue empresario, representante, productor. Ahora le va muy bien. Está un poco retirado de todo aquello. Yo — como otros artistas - le digo agradecimiento. Del TA-BA-RIS (sic), el mismo Piazza, me llevó al teatro Opera». ${ }^{84}$

A El Chúcaro le gustaba «bailar opinando» ${ }^{85} \mathrm{y}$ por eso en su trabajo no se limitaba a reproducir o imitar coreografías. Realizó una gran labor pedagógica, utilizando el folklore como nexo de unión con la tierra. Desde los años 50 y hasta su muerte en 1994 la bailarina Norma Viola le acompañó incondicionalmente; primero como una componente más de la compañía y más tarde también en la labor creativa. Desde 1990 dirigieron juntos el Ballet Folclórico Nacional dependiente del Ministerio de Cultura de la República

\footnotetext{
${ }^{83}$ Las confiterías eran lugares de encuentro donde además de charlar o juntarse para tomar algo, también se baila.

${ }^{84}$ León Benarós, «La vida de El Chúcaro contada por él mismo», Folclore, 9 (1962): 9, acceso el 16 de abril de 2021, https://ahira.com.ar/ejemplares/folklore-no-9/.

85 Ibidem, 11.
} 
Argentina cuyo objetivo queda claro en la descripción que de esta institución podemos leer en la web oficial:

«Ofrece funciones cuyo repertorio está integrado por cuadros coreográficos basados en mitos, costumbres, historias, leyendas y paisajes que reflejan en sus creaciones la expresión de las culturas regionales y tradicionales argentinası. ${ }^{86}$

Un trabajador incansable y absolutamente entregado a la labor pedagógica de hacer conocer el folclore argentino y en general su música por todo el mundo, no podía dejar de lado el tango. Su hija Gabriela Ayala afirmó en una entrevista emitida por la emisora de radio de la Universidad de Salamanca $^{87}$ que no era milonguero ni frecuentaba esos ambientes, pero conocía la danza. Era un hombre estudioso, un gran lector y estaba especialmente interesado en la historia y la cultura de su país. Cuando preparaba una danza llevaba a sus bailarines a conocer el lugar de donde provenía y las personas que allí vivían. Observaban sus movimientos, sus ritmos, cómo caminaban y, en general, su modo de vida. Se empapaban de sus costumbres para entender bien sus danzas. Conseguían una imbricación absoluta entre la vida cotidiana y sus representaciones estéticas.

Omar Ocampo, integrante de la compañía de El Chúcaro y uno de sus más reconocidos pupilos, creó con él la coreografía que hemos tomado como punto de partida en nuestro trabajo. En la única biografía escrita sobre Santiago Ayala, Ocampo habla de él a través de un poema:

«Transformándose en burdeles, hasta el tango se animó, y al duelo de compadritos en un abrazo paró». ${ }^{88}$

\footnotetext{
${ }^{86}$ «Ministerio de Cultura de la República Argentina», acceso el 26 de febrero de 2021, https://www.argentina.gob.ar/cultura/elencos/bfn.

87 Gaby Ayala, entrevista por Laura Alonso, Alevare, Radiousal, 23 de febrero de 2021, acceso el 27 de febrero de 2021, http://radio.usal.es/programa/alevare/.

88 Juan Cruz Guillén, Santiago Ayala "El Chúcaro" y Norma Viola. Antes y después, $2^{\mathrm{a}}$ ed. (Buenos Aires: Balletin Dance Ediciones, 2015), 41.
} 
Los documentos fundamentales que nos aportan información sobre El Chúcaro son los artículos ya mencionados de la revista Folclore y el libro que escribió Juan Cruz Guillén "Fierro", hombre polifacético quien, entre otras muchas labores, ejerció como bailarín bajo la dirección de El Chúcaro y Norma Viola en el Ballet folclórico nacional argentino. En su libro nos ofrece su visión junto a la de muchos otros de la trayectoria del maestro. Fotografías, poemas, opiniones de quienes lo conocieron y sobre todo su visión de la vida del gran bailarín. Suna Rocha afirma, por ejemplo, que «A través de la danza, creó una identidad nacional» ${ }^{89}$. Hace referencia también a otros cuadros coreográficos de base histórica o literaria. Tales serían, por ejemplo, el dedicado a la polémica dicotomía entre civilización y barbarie y el que pone en escena El hombre de la esquina rosada de Borges y Piazzolla.

Queda por tanto demostrada la importancia de la figura de Santiago Ayala no sólo en el folclore argentino sino también en su historia y su cultura. La polémica de si el tango es o no música folclórica existe y, aunque no es nuestro objetivo ocuparnos de esta cuestión ahora mismo, sí podemos afirmar que tanto el tango como el folclore representan -o algunos así lo han entendido- el carácter rioplatense, su idiosincrasia y quizás por eso El Chúcaro se interesó por él. Su propuesta acerca de cómo y cuándo apareció el tango nos permite comenzar nuestro recorrido por la estética del tango desde la segunda mitad del siglo XIX. A continuación, veremos qué nos quiso transmitir este importante bailarín en su propuesta dedicada a los orígenes del tango.

En este capítulo analizaremos la coreografía que El Chúcaro tituló Del gaucho al compadrito basándonos en dos grabaciones que hemos encontrado de este espectáculo. Una retransmite el Festival de Cosquín de 1991 y otro la visita de Santiago Ayala y Norma Viola a Misiones en el año 1993. En ambos casos el vídeo comienza con una presentación por parte del coreógrafo explicando y contextualizando lo que el público va a ver.

89 Ibidem, 51. 
Cronológicamente es imposible que Ayala conociera el nuevo relato, menos amigo de la mitología, de los orígenes del tango, puesto que el libro de Hugo Lamas y Enrique Binda se publicó por primera vez en 1998 y él falleció en 1994. Por ello no es de extrañar que comience describiendo las dos danzas protagonistas de la coreografía -malambo y tango- y al hablar del tango habla de una danza prohibida y rechazada por prostibularia. Sería la parte fundamental de lo que en este trabajo hemos llamado el relato clásico. También es posible que el coreógrafo oyera hablar de la polémica sobre si el tango había nacido o no en los prostíbulos, porque sabemos que Hugo Lamas y Enrique Binda, por ejemplo, llevaban muchos años trabajando en lo que después plasmarían en su libro. Si realmente fue así y Santiago Ayala conoció la polémica, después de ver su coreografía y lo que nos transmite en ella, su posición queda clara: el tango nació en los burdeles.

Lo primero que podemos apreciar en el documento de 1991 que vamos a analizar y que adjuntamos en Anexos, es el letrero DIRECTO COSQUIN que nos sitúa ya en un lugar emblemático para el folclore argentino. En esa ciudad situada al oeste de la provincia de Córdoba tiene lugar todos los años el Festival Nacional de Folklore de Cosquín, el más importante dedicado a la música folclórica argentina y cuyo origen se remonta a finales de los años 50 del s. XX. Pues bien, es en ese contexto en el que El Chúcaro nos presenta un espectáculo sobre tango, género que aparentemente y para muchos expertos nada tiene que ver con el folclore. Queda clara, de nuevo, su posición al respecto.

Santiago Ayala presenta el espectáculo aludiendo al gaucho como personaje de la literatura. Suponemos que no se refiere a su carácter legendario, sino a su frecuente aparición en los géneros literarios. Nos lo presenta como un gaucho del Sur vestido a la manera de 1880 y bailando el malambo. El gaucho del sur vestía botas de potro con los dedos fuera, al contrario que el del norte que vestía botas con tacos. Vemos además en este bailarín las pilchas que entre 1871 y 1920 solía vestir este tipo de hombre: 
«las botas de potro, el chiripá, el facón y el sombrero gacho, con pañuelo atado, debajo». ${ }^{90}$

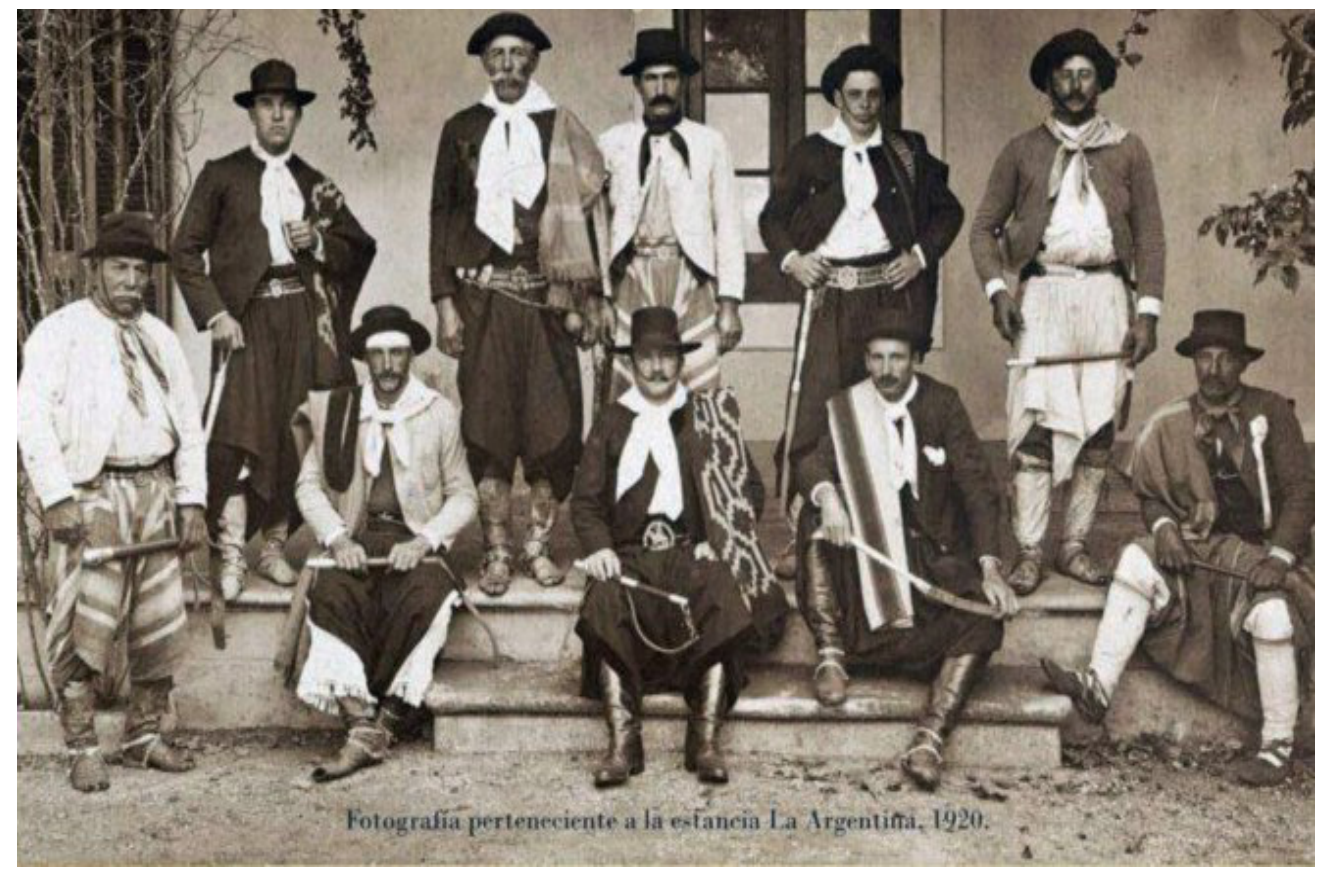

Figura 1. Fotografía conservada en el Museo Histórico del Tuyú, Madariaga, tomada en 1920 en la estancia La Argentina.

El malambo es una danza individual que bailaban los gauchos en la zona pampeana del sur y que les servía para exhibir sus habilidades centradas, fundamentalmente, en los pies. Los zapateos son diferentes según sean del norte o del sur. Claramente en esta coreografía está representado el gaucho pampeano. Prueba de ello es el comienzo rítmico y el cepillado delicado que observamos al comienzo del cuadro.

Pues bien, ese gaucho llegaría a la Plaza de las Carretas — sigue relatando El Chúcaro—, más tarde bautizada como Plaza Constitución, donde tenían lugar intercambios comerciales alrededor del mercado. Allí comenzaría la transformación social del gaucho que dará lugar al compadrito. Es el momento en el que el gaucho pierde definitivamente su libertad al entrar en la

${ }^{90}$ Fernando Assunçao, Pilchas Criollas (Buenos Aires: Emecé, 1991), 253. 
ciudad, se queda en las orillas de la urbe y allí su vida, sus costumbres y su modo de vestir cambia para siempre.

Comienza el espectáculo con el bailarín Roberto Herrera entrando vestido al modo del gaucho bailando un malambo. Se para la música y sigue el Maestro relatando cómo llegaban a la Plaza de las Carretas y, además de realizar intercambios comerciales acudían también a un lupanar en Suypacha y Piamonte en busca de mujeres. Para entrar en ese tipo de lugares debió cambiar sus ropas, así que vemos cómo al mismo tiempo que retoma la danza empieza a cambiar las prendas gauchas por un traje de civil para que le dejen entrar. Un cambio brusco en la música nos anuncia que algo importante se muestra en el escenario. Durante unos segundos la danza cesa para que el bailarín nos muestre el cuchillo, herramienta fundamental a la que nunca renuncia. Vemos cómo le dedica unos movimientos a modo de ritual de pelea antes de dejarlo junto a las prendas que abandona. Vuelve el ritmo y el gaucho sigue quitándose ropas y poniéndose el traje "ciudadano": pantalón oscuro, camisa blanca con rayas, botines en blanco y negro y chaqueta abrochada. Se anuda un pañuelo al cuello al tiempo que recupera el facón, que esconde en la parte trasera del pantalón. El Chúcaro anuncia que ha nacido el compadrito. Efectivamente, vemos la figura mítica del protagonista de los arrabales rioplatenses y debemos detenernos en un elemento importante: el cuchillo. Se podría considerar este como nexo de unión entre los dos tipos masculinos, un eslabón que los une socialmente y que representa la valentía, el coraje, en definitiva, eso a lo que un hombre de finales del XIX no debía renunciar. Era una señal de virilidad y hombría. No podemos saber si exactamente los hechos sucedieron como nos lo quieren mostrar en este cuadro que, al mismo tiempo, supone una síntesis de hechos más complejos, evidentemente. Lo que sí podemos concluir claramente al analizarlo es que el hombre dejó el campo y llegó a la ciudad a la que tuvo que amoldarse, cambiar ciertas costumbres, ropas, compañías, pero la valentía que mostró como hombre solitario del campo la conservará —o, al menos, lo intentará- en los arrabales porteños. El Chúcaro nos dice que el compadrito heredó su gran habilidad con el cuchillo del gaucho surero y que, además, llevar un revólver en esos ambientes se consideraba un acto cobarde. El facón será siempre un 
símbolo del gaucho y también del compadrito $y$ todos esos diferentes arquetipos masculinos que conocerán el final del s. XIX.

A continuación, nos presenta la compañía de Ayala otro cuadro en el que el compadrito se va a bailar tango al lupanar. Comienza a sonar el ritmo básico de la habanera que es uno de los antecedentes, junto a la milonga, del tango. Se pasea entre las mujeres con ese andar chulesco que predomina en su caricatura y bailan todos. Hay más hombres vestidos como él que juegan y beben. Cada uno toma una pareja y la señal para cambiar de música es un gesto cargado de simbolismo: una palmada en el trasero de una de las mujeres. Empieza entonces a sonar una milonga que bailan todos. En un momento el tempo vuelve a bajar, el ritmo de habanera lenta les permite exagerar el contacto de los cuerpos y poner fin al cuadro.

En un segundo cuadro registrado en el vídeo que presentamos adjunto en Anexos bajo el título Orígenes del tango $2^{a}$ parte ${ }^{91}$, tres de los visitantes del lupanar juegan a las cartas mientras otros hombres y mujeres observan. Los que juegan van marcando un ritmo con los pies hasta que se produce un conflicto y comienza la danza lenta que dará lugar a una pelea a cuchillo entre dos de los jugadores, uno de ellos es nuestro protagonista. Este consigue arrinconar al rival con el facón, pero decide no rematar la faena, perdonarle y devolverle el arma. En realidad, no le hace falta, ya ha quedado clara su superioridad en la pelea así que no hay por qué derramar sangre. Su honor está más que a salvo. El gaucho tenía un código moral sencillo, pero estricto. Defendía con valentía su honor, pero no era amigo de hacer sangre si no era estrictamente necesario. Esto lo encontramos también en los orilleros, pero, como veremos, no todos darán muestra de una moral tan férrea. El cambio del campo a la ciudad supuso también de alguna manera un proceso de desmoralización que está representado simbólicamente en esta mitología de compadritos y malevos, lo que quizás ayuda a entender mejor lo que supuso esa gran transformación y urbanización apresurada del terreno. Cuando presentemos el análisis de los diferentes tipos masculinos veremos cómo la gran diferencia entre uno y otro tiene que ver, fundamentalmente, con su

\footnotetext{
${ }^{91}$ Véase DVD adjunto.
} 
código moral. Van heredando los rasgos de unos a otros pero en los últimos esas cualidades llegan a ser, meramente, apariencia.

Pues bien, después de esta pelea aparece otro de los personajes que supuestamente $-\mathrm{y}$ siempre según el relato clásico de los hechos- era frecuente en estos ambientes: la policía. En este cuadro presentan a un agente de la autoridad que se deja embaucar fácilmente por las mujeres del lupanar y por el alcohol que le hacen beber. Todos los asistentes, con el policía y una de las mujeres como pareja central, bailan una divertida milonga. Para que quede claro quién manda, la coreografía termina con la pareja del agente cogiéndole a él en brazos y no al revés, como seguramente sería más lógico. Este final en tono humorístico cierra el documento en el que hemos visto reflejada no sólo la transformación del gaucho en compadrito sino también el ambiente donde los primeros narradores situaron el tango de finales del siglo XIX.

En el documento audiovisual que muestra el espectáculo en Misiones El Chúcaro se extiende más en sus explicaciones iniciales y cuando comienza el cuadro y el gaucho se cambia de ropa, la única diferencia que observamos con respecto al de Cosquín es que añade un elemento, las boleadoras. Una vez que el compadrito está completamente constituido aparece un grupo de mujeres cada una con una banqueta y unos hombres con una mesa. Está conformado ya el ambiente del lupanar. Escuchamos la habanera y el vídeo se corta. Entendemos que lo siguiente sería el cuadro descrito en el documento de Cosquín pero no hemos encontrado el documento que lo recoge.

De la coreografía creada por El Chúcaro nos interesan varios aspectos. El primero es la línea tan delgada que separa la música folclórica y el tango, sin que sea nuestro cometido entrar en la polémica de si este forma parte o no del folclore. Además, entendiendo que el bailarín del que hablamos era un gran conocedor de la sociedad, la cultura y la música de su país nos interesa mucho su visión respecto al tango. Ya hemos dicho que su teoría encaja en el relato clásico bien porque apoya su enfoque o bien porque las nuevas teorías salieron a la luz años después de su muerte. Pero nosotros queremos dar un paso más y extraer de su propuesta nuevas conclusiones. Por ejemplo, 
el hecho de que, sea o no cierta y real la evolución del gaucho al compadrito que expone, lo que sí encontramos es una continuidad masculina entre finales del XIX y la actualidad. En el cuadro Del Gaucho al compadrito que acabamos de analizar se ve reflejada una primera etapa: la urbanización de Buenos Aires y el cambio radical que algunos hombres del campo asumieron para adaptarse a un nuevo ecosistema, la ciudad. En los diferentes ámbitos estéticos que analizaremos en este trabajo veremos cómo el gaucho y el compadrito comparten, además del cuchillo, un código moral semejante en el que destacan por encima de otros aspectos la lealtad y el coraje. En la literatura de la época, en las letras de tango y en el lenguaje del momento se refleja perfectamente ese código ético en el que la hombría y la virilidad se convierten en una constante en las relaciones sociales que el tango recogerá de alguna manera en su coreografía.

Desde que empezó a narrarse en los años 30 el tango se entendió como un hecho social marginal propio de los prostíbulos y esto interesó mucho al mundo entero. Para nosotros esta narración tiene, en lo que a la puesta en escena se refiere, un centro clave: sus movimientos y sus pretensiones de ser considerado un determinado tipo de hombre. Pues bien, ha quedado expuesta la propuesta de El Chúcaro y con ella el punto de partida de nuestro trabajo. El siguiente paso en nuestra investigación ha sido buscar en la literatura, el lunfardo, las letras de tango y hasta en el cine, muestras de cómo este relato caló profundamente en el imaginario popular e intelectual y contribuyó a configurar una apariencia muy particular en este género. Por otro lado, veremos cómo todos los elementos que intervinieron en la configuración de este relato se basa en un hecho: la necesidad del hombre de presentarse como tal y así preservar su identidad.

\subsection{Masculinidad}

Hemos querido establecer en estos párrafos que preceden los tres puntos de vista desde los que, a lo largo de más de un siglo, ha sido narrada la historia del tango, además de presentar el estado de las investigaciones actuales. Nos toca ahora detenernos brevemente en aclarar desde cuándo y de qué manera se han llevado a cabo estudios sobre el otro concepto 
fundamental en nuestra tesis: la masculinidad. Asimismo, nos situaremos en el estado actual de las investigaciones que relacionan ambos conceptos: tango y masculinidad.

Hernando Muñoz Sánchez, en su Tesis Doctoral presentada en el año $2014^{92}$, analiza la masculinidad centrando su estudio en la vida de hombres colombianos. Nos interesa especialmente su exposición acerca de cómo, cuándo y por qué surgen los primeros estudios sobre masculinidad. Nos vamos a basar principalmente en la información que nos aporta este trabajo para resumir lo que nos parece más relevante.

Para empezar, es importante constatar que los estudios de masculinidad responden a la necesidad de entender el papel del hombre en el mundo occidental una vez que el feminismo ha impulsado los trabajos sobre género. Así, el auge del feminismo sería la primera razón que Muñoz Sánchez atribuye al hecho de que proliferen los estudios sobre este tema. La segunda razón tiene que ver con lo que llama crisis de la masculinidad:

«Las percepciones iniciales de este tipo de crisis indicaban una incidencia negativa en los índices de desarrollo económico de naciones occidentales, en las metas de productividad industrial y empresarial, así como en los perfiles de morbi-mortalidad, especialmente de los varones. Por ejemplo, se analizaba la forma como ciertas situaciones críticas en el orden personal y familiar de los varones que se sentían en "crisis" derivaban en reducciones sensibles en la esfera de la producción y en los indicadores de su propia salud mental y calidad de vida». ${ }^{93}$

La tercera razón que justifica la aparición de los estudios sobre los hombres y las masculinidades deriva de la necesidad de entender el funcionamiento de la sociedad y las relaciones de quienes la componen.

Fundamentalmente los estudios sobre masculinidad adquirieron importancia a partir de los años 80 , aunque ya había sido tema de estudios

92 Hernando Muñoz Sánchez, «Hacerse hombres: la construcción de masculinidades desde las subjetividades: un análisis a través de relatos de vida de hombres colombianos» (tesis doctoral, Universidad Complutense de Madrid, 2015).

${ }^{93}$ Ibidem, 38. 
en décadas anteriores desde tres perspectivas diferentes: un punto de vista clínico — con Freud como protagonista en los primeros años del s. XX一, otro basado en la psicología social — principalmente en países anglosajones y surgen en los años 30- y finalmente teniendo en cuenta todo aquello aportado por la antropología, la historia y la sociología en la segunda mitad del pasado siglo.

Nos interesa especialmente el concepto de masculinidad desde un punto de vista histórico ya que gracias a los estudios en esta disciplina se pudo llegar a la conclusión de que este concepto es una creación del mundo moderno y, por tanto, un producto cultural. Esta masculinidad moderna está relacionada directamente, según Hernando Muñoz, con el desarrollo del sistema capitalista y «la competencia entre varones» ${ }^{94}$ y también «la formación del modelo de familia como sustento de los Estado-Nación republicano que pone a los hombres en el lugar de ciudadanos proveedores y heterosexuales» ${ }^{95}$.

Los estudios de las últimas décadas nos plantean varias definiciones para explicar qué significa ser hombre y, teniendo en cuenta lo que nos interesa mostrar en nuestro trabajo, nos quedamos con la que propone Michael Kimmel a finales de los 90:

«La virilidad no es estática ni atemporal, es histórica; no es la manifestación de una esencia interior, es construida socialmente; no sube a la conciencia desde nuestros componentes biológicos; es creada en la cultura. La virilidad significa cosas diferentes en diferentes épocas para diferentes personas ${ }^{96}$.

También nos interesa el planteamiento de David Gilmore quien, en la misma década que Kimmel, afirma que:

\footnotetext{
94 Ibidem, 42.
}

95 Ibidem, 43.

96 Michael Kimmel, «Homofobia, temor, vergüenza y silencio en la identidad masculina», en Teresa Valdés y José Olavarría (eds.). Masculinidad/es. Poder y crisis. Ediciones de las Mujeres, 24 (Chile: Isis Internacional-Flacso Chile), 49, citado en María José Jociles Rubio, «El estudio sobre las masculinidades. Panorámica general», Gazeta de Antropología 2001, 17, artículo 27. 
«La masculinidad es la forma aprobada de ser varón en una sociedad determinada, aclarando que ese ideal de masculinidad no es psicogenético o mítico sino que se constituye como un ideal impuesto culturalmente, al cual los hombres deben adecuarse concuerden o no psicológicamente con el mismo». ${ }^{97}$

No puede ser casual que la época en la que comienzan a generalizarse los estudios sobre lo masculino coincida con el renacimiento del tango. Como ya sabemos, después de la gran época dorada del tango el género decayó hasta convertirse en una música de minorías invadidas por la nostalgia. Durante los años sesenta y setenta el éxito del rock relegó muchos géneros musicales a un segundo plano. Una década más tarde el tango resurge, esta vez, como danza. El baile es la representación visual del género porteño y por tanto deja al descubierto sus rasgos más evidentes. Entre estas características que se empiezan a mostrar están el modo como se relacionan el hombre y la mujer en su desarrollo. En lo que respecta a una música popular, el público aprecia algunas de sus estructuras y otras no. Por ejemplo, no es fácil que una mayoría reconozca la construcción armónica, melódica o rítmica, pero sí está al alcance de cualquiera la relación que se establece entre quienes la bailan. De la importancia de estudiar el tango desde la perspectiva de la masculinidad nos hablan Maristany y Peralta en su recopilación de ensayos publicados bajo el título de Cuerpos Minados en 2017:

«Aludir al tango para introducir esta recopilación de artículos sobre masculinidades en Argentina responde no solo a que ese fenómeno cultural exhibe un modelo paradigmático de binarismo de género, en el que se puede aprender a ser "varón", sino que ese mundo de "guapos" y "compadritos" se instaló, a pesar de su arraigo exclusivamente rioplatense, como rasgo identitario de la nacionalidad argentina en su conjunto». ${ }^{98}$

\footnotetext{
${ }^{97}$ Hernando Muñoz Sánchez, «Hacerse hombres: la construcción de masculinidades desde las subjetividades: un análisis a través de relatos de vida de hombres colombianos» (tesis doctoral, Universidad Complutense de Madrid, 2015), 55.

98 José Javier Maristany y Jose Luis Peralta, «Masculinidades: modelos para desarmar», Cuerpos minados (La Plata: EDULP, 2017).
} 
Por ello nuestra opinión es que en un ambiente en el que empieza a plantearse la masculinidad como una construcción cultural, los estudiosos no podían pasar de largo ante una danza con roles de género tan marcados.

Veremos al analizar los diferentes estilos de tango que hay errores al considerar que estos roles ya suponían férreos límites en los orígenes del tango, puesto que hemos encontrado documentación que nos lleva a una danza popular bailada en ambientes familiares y de ocio indistintamente entre dos hombres, dos mujeres, o por parejas mixtas. Esto nos lleva de nuevo a la construcción social de la masculinidad y a la importancia de contextualizar los hechos al intentar hacer historia.

Es algo muy evidente que los estudios de género se centraron fundamentalmente en uno de ellos, el femenino, y por eso también, dentro de los estudios de género, los que se ocuparon de la masculinidad son más escasos. Así lo afirmaba en 2010 Todd Reeser:

«[P]uesto que la masculinidad no ha sido objeto de estudio en tanto género, su invisibilidad puede ser estudiada como uno de sus elementos constitutivos. [...] los intentos por mantener la masculinidad en silencio - sin marca, sin género- es uno de sus caracteres recurrentes que puede y debe ser estudiado». ${ }^{99}$

En este sentido podemos establecer como pionero el trabajo de Carolina Rocha titulado Modern Argentine Masculinities de 2013 en el que aborda el estudio de las masculinidades desde diversas perspectivas como la literatura, la música o el cine.

En cuanto a los estudios sobre tango y masculinidad podemos afirmar que son escasos los trabajos serios al respecto $y$, mucho más los que ofrecen un enfoque original. En todo caso, tratan la relación entre tango y género, como es el caso del interesante libro de Magali Saikin Tango y género.

${ }^{99}$ Todd Reeser. Masculinities in Theory. An Introduction (Chichester: Wiley-Blackwell, 2010), 9 citado en José Javier Maristany y Jose Luis Peralta, «Masculinidades: modelos para desarmar», Cuerpos minados (La Plata: EDULP, 2017), 10. 
Identidades y roles sexuales en el Tango Argentino. Ya en los primeros párrafos de este texto nos encontramos la afirmación que sigue:

«El discurso tanguero, en lo que respecta a las relaciones de género, es un discurso codificado, reducible a términos paradigmáticos que explican al tango en su esencia: la relación 'hombre - mujer'. En ningún otro sitio es el hombre más varonil (macho) y la mujer más femenina (hembra). En ninguna otra danza el erotismo está tan presente y el abrazo es tan pasional: el Tango Argentino ofrece el sitio 'oficial' por excelencia a la heterosexualidad». ${ }^{100}$

Saikin analiza el papel del hombre en el tango en relación con la mujer, la define como una relación de poder y a partir de ahí entra en diversas cuestiones como el machismo, el travestismo o la homosexualidad. No es nuestro caso. Nosotros nos centramos en la figura del hombre como protagonista de una historia o leyenda creada y situada en los arrabales del Río de la Plata. En cómo se consiguió que la imagen de los hombres de finales del s. XIX y principios del s. XX determinara la coreografía del tango, o parte de ella. Por lo tanto, no nos centramos en la relación entre hombre y mujer sino en la figura del hombre, sus gestos, su carácter, su ropa y su representación. Sin embargo, y aunque no estemos de acuerdo con todas las afirmaciones de la autora, nos parecen interesantes muchas de sus aportaciones que pasamos a presentar. Su punto de partida es claro, como hemos podido leer en la cita anterior: el reconocimiento del tango como la danza en la que el hombre es más varonil y la mujer más femenina.

Su objetivo es «estudiar las relaciones de género que se esconden y determinan al tango desde sus orígenes ${ }^{101}{ }^{10}$. Partiendo de estas premisas y a través del empleo de palabras como 'virilocentrismo', 'machismo', 'virilizar' Saikin afirma que el gran creador del tango danza es el hombre y que la mujer es un elemento reemplazable. Propone, por tanto, el machismo como base fundamental de este género.

100 Magali Saikin, Tango y género. Identidades y roles sexuales en el Tango Argentino (Stuttgart: Editorial Abrazos books, 2004), 7.

101 Ibidem, 8. 
También trata el tema de la homosexualidad en el tango y, de hecho, dedica un subcapítulo a las que denomina como Paradigmas masculinos genéricamente ambiguos ${ }^{102}$. En esta parte de su estudio la autora describe figuras tan relevantes en el tango como Eduardo Arolas, Agustín Magaldi o Carlos Gardel. Los describe como hombres delicados preocupados por su aspecto físico y que a menudo eran fotografiados junto a amigos varones. En el caso de Magaldi destaca también como prueba de su supuesta ambigüedad el hecho de cantar tangos de mujeres. De los tres autores que Saikin menciona nosotros nos ocupamos en nuestro trabajo solo de la figura de Carlos Gardel por considerarlo un icono universal del tango, alguien que puede establecerse como referencia tanguera en cualquier parte del mundo.

En definitiva, Magali Saikin nos aporta una visión de género y nos aporta mucha información, sobre todo, relacionada con la recepción del tango, algo que nos interesa sobremanera. El estudio de género no solo consigue su objetivo de proclamar el carácter machista de esta música rioplatense, sino que añade más elementos que ayudan a configurar su aspecto sensible, su imagen pública. Retomando nuestra pregunta de qué piensa una persona en cualquier parte del mundo cuando oye hablar de tango, podemos afirmar que todo lo que se ha contado sobre él aporta gran cantidad de ingredientes a esa imagen mental.

Encontramos también los trabajos de Marta Savigliano a los que nos referiremos en el próximo capítulo, pero de nuevo observamos un enfoque diferente, el de género, además de otras perspectivas como la clase o la raza. Savigliano ha trabajado intensamente aspectos relacionados con bienes culturales e ideología sobre todo en relación al sistema capitalista y la globalización, y también es co-responsable, por ejemplo, del libreto de una ópera-tango titulada Angora Matta. Nos interesan especialmente dos trabajos, el libro Tango and the political economy of Passion ${ }^{103} \mathrm{y}$ el artículo «Malevos llorones y percantas retobadas: el tango como espectáculo de razas, clases e

\footnotetext{
102 Ibidem, 136.

${ }^{103}$ Marta Savigliano, Tango and the political economy of passion (Boulder, Colorado: Westview press, 1995).
} 
imperialismo» ${ }^{104}$. El objetivo de esta antropóloga es superar lo que para ella supuso una simplificación de la visión del tango como conflicto de género con la intención de dejar de lado o directamente ocultar problemas sociales más profundos asociados a este género. Siguiendo a las teorías descritas por Hernando en su tesis doctoral, Marta Savigliano destaca el carácter histórico del machismo y reconoce en él una dimensión macropolítica ${ }^{105}$. Encontramos aquí, de nuevo, un estudio de gran amplitud teórica pero que trata el tema del tango desde una perspectiva de género. Sin duda, sus estudios son imprescindibles para quienes estamos interesados en el papel social y político del tango a nivel mundial, pero en este trabajo nos centramos en El Río de la Plata y en quienes hicieron posible desde diferentes perspectivas la configuración de su imagen.

También encontramos interesantes trabajos contemporáneos a los de Savigliano y Saikin como el libro del antropólogo y profesor especialista en deportes Eduardo Archetti titulado Masculinidades. Fútbol, polo y tango en la Argentina y su artículo «Masculinidades múltiples. El mundo del tango y del fútbol en la Argentina». De nuevo en estos trabajos se recoge la descripción de los roles masculinos y femeninos del tango y, en este caso, se presentas paralelamente a otro fenómeno social imprescindible en Argentina, el fútbol.

Quizá el trabajo al que más nos acercamos es el de Javier Gasparri titulado "Che varón. Masculinidades en las letras de tango»" ${ }^{106}$. Además de centrarse en la poética del tango nos propone una serie de ideas que secundamos y que tienen que ver con la relación entre el gaucho y el compadrito y sobre todo con el ideal de masculinidad. Sin embargo, este

${ }^{104}$ Marta Savigliano, «Malevos llorones y percantas retobadas: el tango como espectáculo de razas, clases e imperialismo», Relaciones de la Sociedad Argentina de Antropología, 19 (1994).

105 Marta Savigliano, Tango and the political economy of passion (Boulder, Colorado: Westview press, 1995), 46.

106 Javier Gasparri, «Che Varón. Masculinidades en las letras de tango», Caracol, 2 (2011), acceso el 23 de abril de 2021, https://www.revistas.usp.br/caracol/article/view/57660/60715. 
trabajo sigue sin recoger las investigaciones más actuales y no se centra en la imagen del tango, siendo este nuestro principal objetivo.

Como es ya más que evidente, en el estudio de la masculinidad como tal no existe el volumen teórico que invade el mundo del tango. En nuestra opinión esto se debe a tres razones fundamentales: la primera sería que el primer documento que intenta relatar los orígenes y el desarrollo del tango data de $1913^{107} \mathrm{y}$, por tanto, podemos decir que esta disciplina cuenta ya con más de cien años de documentación. La segunda razón tiene que ver con nuestros intereses, puesto que lo que para nosotros es relevante no tiene que ver solo con la masculinidad, eso sería solamente un punto de partida. Nuestra intención en estos párrafos era mostrar los estudios que relacionaban tango y masculinidad y estos son verdaderamente escasos en relación, por ejemplo, a los estudios sobre la mujer en el tango. Por último, las crónicas sobre la masculinidad aún siguen un mismo camino, que es dejar constancia de las desigualdades históricas entre hombres y mujeres en diversos aspectos de la historia de la humanidad. Nada que ver con la polémica entre las cuatro corrientes teóricas que hemos establecido en este trabajo para entender el estudio del tango hasta hoy. Podríamos decir que todos los trabajos sobre lo masculino existentes hasta el momento se complementan para formar un todo y las diferentes perspectivas al afrontar la historia del tango parecen, en muchos momentos, ser incompatibles.

A partir de este momento comienza la exposición de lo que nuestro trabajo pretende aportar al estudio académico del tango. Tanto las perspectivas desde las que el tango ha sido estudiado como el modo en que ha sido tratado el tema de la masculinidad, serán una continua referencia para nosotros, puesto que estas cuatro maneras de enfocar la historia del tango han determinado rotundamente la apariencia de este género musical.

107 Nos referimos a la reseña publicada en el diario Crítica y escrita por El viejo tanguero a la que hemos aludido ya en la narración del relato clásico. 


\section{LA MASCULINIDAD EN EL TANGO RIOPLATENSE.}

Marta Savigliano en su artículo «Malevos llorones y percantas retobadas: el tango como espectáculo de razas, clases e imperialismo» describe claramente el proceso que sufre el hombre en su camino de transformación del siglo XIX y cómo va aprendiendo a mostrar el mayor coraje posible haciendo gala de una virilidad incuestionable. Estos hombres son algunos de los protagonistas de los primeros abrazos del tango y los más importantes desde el punto de vista de lo que hemos llamado el relato clásico:

«La urbanización y la industrialización habían dejado atrás a sus mujeres; y estos proyectos "civilizatorios" eran instigados por otros hombres. Urbanización e industrialización tenían el rostro de esos hombres ricos que miraban, lascivamente, a sus mujeres pobres. Estos hombres poderosos pagaban por abrazar a las mujeres pobres, ya que no podían tocar a las mujeres de su propia estirpe sin comprometerse.

Es difícil decir si a los guapos, realmente, les importaba la suerte de sus mujeres; aprendieron a mostrarse duros, a despreciar la vida y a mirar a las mujeres con desdén. Tal vez aprendieron a despreciar la vida peleándose a muerte por mujeres con el objeto de seguir probándose hombres, a pesar de su clase social. La identidad del macho tanguero nace de esta contradicción. Las identidades de estas mujeres, que no llevan más nombre que el de su color y etnicidad (María la Vasca, la rubia Mireya, la Moreira, etc.), nacieron de esta competencia entre hombres. Los machos de diverso color y clase social que jalaban a las mujeres desde múltiples direcciones dieron forma a las identidades sin nombre de estas mujeres». ${ }^{108}$

Estos machos de los que nos habla Savigliano son los protagonistas de nuestro trabajo, pero no sólo ellos, sino también la leyenda que se generó a partir de sus vidas y, fundamentalmente, lo que la sociedad recogió de sus historias a través de elementos como el lenguaje, el cine, la literatura y la danza. El análisis de estos ámbitos nos ha permitido dibujar un cauce por el

108 Marta Savigliano, «Malevos, llorones y percantas retobadas: el tango como espectáculo de razas, clases e imperialismo», en Relaciones de la Sociedad Argentina de Antropología, 19 (1994), 79-104. 
que este fomento de la masculinidad ha transitado condicionando de un modo determinante la imagen pública del tango rioplatense.

Además, esta autora nos propone la idea de que la economía política internacional intentó establecer los paradigmas de hombría para el primer mundo y virilidad —relacionada más con el término 'macho'- para el tercer mundo. En nuestra lectura de las fuentes tanto literarias como académicas no hemos encontrado una clara diferenciación en ese sentido. Tanto el término hombría como virilidad están presentes en todos los textos que hemos consultado. Si bien podemos observar una tendencia a emplear los términos como la investigadora nos lo propone no creemos que se deba ser tan tajante al afirmar tal aseveración. En todo caso, es una aportación realmente interesante ya que propondría una diferenciación semántica en lo que se entiende por masculinidad en unos países y en otros. A pesar de ello, no es nuestro cometido en este trabajo ya que nosotros nos centramos en lo que se entendió por masculino en el Río de la Plata cuando el tango se originó y en determinadas etapas posteriores.

Blas Matamoro, a quien ya hemos presentado en el Estado de la Cuestión, nos describe así la sociedad de los primeros años del s. XX:

«La desmilitarización posterior al término de las guerras civiles y la guerra del Paraguay y la brusca invasión inmigratoria, en gran parte retenida por el puerto, crearon una población masculina estable cuya concurrencia a los lugares de prostitución aseguraba una extensa clientela». ${ }^{109}$

Es algo lógico pensar que la población fuera eminentemente masculina y que esto determinó todo el engranaje social del territorio. Incluso si la diferencia entre la cantidad de hombres y mujeres no hubiera sido muy significativa, es fácil imaginar un paisaje más masculino que femenino en las calles de unas ciudades en desarrollo. Pero ¿a qué nos referimos con masculinidad? ¿Cuáles eran los rasgos que debía observarse en un hombre para calificarlo de varonil? ¿Qué significa que un hombre hace alarde de su hombría? Debemos tener claro lo que significan para nosotros cada uno de

\footnotetext{
${ }^{109}$ Blas Matamoro, La ciudad del tango (Buenos Aires: Editorial Galerna, 1969), 36.
} 
estos términos y ello nos ayudará a entender mejor qué es lo que vemos en el tango que nos hace aseverar que en él la masculinidad ha sido un ingrediente fundamental a la hora de configurarse como danza y de darse a conocer en el mundo entero.

En la Introducción ya hicimos referencia al Diccionario de la Real Academia Española que empleaba los términos 'entereza' y 'valor' al hablar de hombría y de lo masculino. $Y$ exactamente estas cualidades eran las que los protagonistas del tango $-\mathrm{y}$, en general, la mayor parte de los hombres hasta hace bien poco- querían demostrar. Era y, en cierta medida sigue siendo, un modo de reafirmarse en su identidad. Un ser humano se considera masculino por una determinada configuración de su cuerpo pero, además, durante siglos el hombre tuvo que ser modelo de valentía, coraje, iniciativa, frialdad. Así, nos encontramos en muchas manifestaciones cotidianas expresiones como hacerse un hombre, llevar los pantalones, los hombres se visten por los pies, Ilorar como una mujer o, en un estilo más tanguero, un hombre macho no debe Ilorar. El cumplir con todas estas atribuciones dio lugar a una actitud en la mayoría de ellos que se vio también reflejada en un modo de caminar, de mirar y, en definitiva, de relacionarse con el mundo. No sólo en contraste con el género femenino, ante el cual debía mostrarse erguido física y psicológicamente, sino ante la sociedad en general. Un hombre debía comportarse como un hombre si no quería verse juzgado severamente.

En cuanto a todos los términos relacionados con esta masculinidad no vemos grandes diferencias semánticas entre ellas. Si afirmamos, por ejemplo, que en prácticamente todos los relatos de Eduardo Mallea el escritor argentino emplea el término viril, no se podría asegurar que, si hubiera empleado otro vocablo como, por ejemplo, varonil, el significado o su intención habrían variado. De hecho, en el Diccionario de la Real Academia Española las definiciones de estas dos voces son exactamente las mismas. Hombría, viril o varonil son términos que se refieren a todos aquellos rasgos que hacían que un hombre fuera considerado realmente un hombre y tienen que ver con el valor, la entereza, la frialdad y la contención sentimental. Habitualmente estos rasgos se agudizan cuando el varón entra en conflicto con otro hombre o en 
su relación con las mujeres. En un texto publicado en la revista Martín Fierro en el año 1926 se describe de un modo muy interesante cómo el tango tuvo un origen orillero haciendo referencia al compadrito y su «hombría de escaparate ${ }^{110}$. Veremos a continuación cómo este personaje, efectivamente y según hemos podido comprobar en las fuentes comentadas, era descrito como alguien que presumía de su apariencia y sus maneras en la vida social, pero que distaba mucho de la estricta moralidad de sus predecesores como el guapo o el gaucho.

En el otro lado tenemos el imaginario femenino, fundamental también en el tango. Nos encontramos con las milonguitas, las chinas, las madres, las costureritas que dieron un mal paso ${ }^{111}$, la mujer que traiciona y la que abandona. Todas ellas símbolos de la opresión de género ejercida sobre la mujer durante años y que merecerían también ser objeto de un amplio estudio.

Hemos dicho ya que no ha sido nuestra intención estudiar el comportamiento del género masculino con respecto al femenino, ni de juzgar el sometimiento de la mujer dentro de una sociedad patriarcal. Todo esto está también en el tango, obviamente, pero lo que a nosotros nos interesa ahora es mostrar cómo esas actitudes masculinas ejercieron una enorme influencia en la historia del tango por dos motivos: el primero es que determinó la coreografía del tango y el segundo es que generó una leyenda alrededor del género que consiguió que llegara a todos los continentes, sin excepción. No queremos que nuestro estudio sea considerado, por tanto, un trabajo de género. Estudiamos, en definitiva, lo masculino en relación con el tango y, especialmente, su danza, así como la imagen visual con la que sigue recorriendo el mundo. Los ambientes de los que hablaremos son los que Pablo Ben Ilamó en 2007 «espacios de sociabilidad masculina»:

110 Sergio Piñero, «Salvemos el tango», Martín Fierro, 19 (1925): 128.

${ }^{111}$ La historia que cuenta el poeta Evaristo Carriego en los once poemas editados bajo el título La costurerita que dio aquel mal paso se convirtió en un símbolo y un lugar común en las letras de tango. Con esta expresión se alude al caso de mujeres que, seducidas por un hombre y con ciertas ansias de salir de su rutinaria vida, se alejan de su casa para vivir una aventura que, casi en todas las ocasiones, termina en fracaso. 
«urban lowest deals with one aspect of that topic-plebeian masculinity a and demonstrates how demography, the job market, and fam shaped the emergence of spaces of male sociability. It was that cultural negotiations of masculinity took place through involving the male sexual capacity to subjugate ${\text { others }{ }^{112}}^{112}$

En este capítulo entramos de lleno en la vida de estos hombres dedicando un primer punto a describir todos los prototipos de los que nos hablan tanto la historia como la leyenda. A continuación, veremos cómo el lenguaje de la calle, la literatura, las letras de tango y especialmente la danza recogen el legado de esta parte de la sociedad y consiguen crear entes artísticos que serán universalmente reconocidos y admirados. Además, analizamos la trayectoria y el tratamiento público de dos de las más importantes figuras masculinas de este género musical: Carlos Gardel y Julio Sosa. Hemos decidido acercarnos a estos dos iconos del tango por considerarlos también parte del cauce sobre el que la masculinidad se fue abriendo camino y fue definiendo movimientos, gestos y actitudes que durante mucho tiempo se han considerado inherentes a esta música urbana.

Partiendo pues de la propuesta de El Chúcaro y con el objetivo de demostrar que la masculinidad ha vehiculado la estética tanguera y que es esa cualidad de masculino es el nexo de unión entre el gaucho y el compadrito, presentamos a continuación las evidencias que lo demuestran.

3.1. Roles de género masculino en el Río de la Plata (1880-1916).

En la exposición y descripción de los arquetipos masculinos que protagonizarán el devenir del tango hemos querido establecer unos límites cronológicos que son el año 1880 como fecha aproximada en el que emerge el tango en el Río de la Plata y 1916, momento en el que comienza la etapa conocida como tango canción. Hemos considerado importante hacer esta acotación para dejar bien claro que la leyenda del compadrito y de los demás

112 Pablo Ben, «Plebeian Masculinity and Sexual Comedy in Buenos Aires, 18801930», Journal of the History of Sexuality, Vol. 16, 3 (2007): 436. 
prototipos masculinos estaba ya asimilada en el género cuando llega el gran éxito del tango como altavoz de nostalgias a través de sus textos. Es, por tanto, la primera época en la que nos detenemos y, por lo tanto, la que supone el punto de partida de nuestras tesis.

El Chúcaro, en su propuesta de cómo surge el tango, pone al compadrito en el centro y nos presenta al gaucho como antecedente inmediato. Del gaucho al compadrito y del malambo al tango. Entendiendo esta representación no como una narración histórica sino como una síntesis de lo que sí pudo suceder nos quedamos con el concepto que subyace: el cambio de la vida rural a ambos lados del Río de la Plata al Estado moderno, del campo a la ciudad, o a sus orillas. Ese es el momento de gestación del tango o al menos lo más lejano de él que conocemos y, aunque nadie pueda afirmar cómo surge exactamente, sí podemos definir los actores sociales del momento para intentar saber cómo se fue creando un conjunto de rasgos y actitudes que perdura todavía hoy en algunos tipos de tango y en la carta de presentación del género.

Blas Matamoro, al clasificar los grupos sociales, propone tres: el compadre o malevo, el canfinflero o cafisho y el gil o compadrito. Nosotros, además de añadir como precedente al gaucho, proponemos una clasificación más concreta y añadimos un enfoque que propone una línea de continuidad entre cada uno de estos arquetipos y el siguiente.

Hemos hablado ya de que el proceso de urbanización de un territorio supone también un camino de desmoralización o al menos de cambio de referentes éticos y morales. Creemos, además, que en el territorio rioplatense estos cambios están perfectamente representados en los prototipos masculinos desde el gaucho hasta el compadrito, pasando por otros como el compadre. Es más, estos personajes de historia y leyenda se convierten en referentes morales para la sociedad y estéticos para la danza. Pero existe una gran diferencia entre lo estricto del código moral del gaucho y el malevo, por referirnos a los dos tipos más lejanos entre sí. Se produce una degeneración en el sentido de que se le va otorgando mayor laxitud a las normas morales, hasta que prácticamente solo sirven para sustentar una determinada apariencia. 
Antes de comenzar este análisis debemos aclarar que los términos muchas veces se confunden los unos con los otros. Esto quiere decir que en algunas fuentes nos encontramos con que distintos tipos masculinos parecen el mismo. Nuestra confianza en el lenguaje y en su capacidad para dar voz a cada tipo de sociedad nos lleva a la idea de que si existen palabras diferentes han existido, en algún momento, referentes reales distintos. Aunque el paso del tiempo los haya diluido y posteriormente se empleen diferentes palabras para un mismo tipo de hombre, por alguna razón que no podemos alcanzar existió una realidad para cada palabra.

Nosotros estudiamos en este trabajo un momento de transición en el territorio rioplatense y tenemos claro que no es una casualidad que estos prototipos masculinos que tanto se parecen entre sí hayan surgido en un momento de cambio de la vida rural al estado moderno, del campo a la ciudad, de una época artesanal a la industrial. En todo caso, lo que nos interesa es sintetizar los rasgos comunes a todos estos hombres y demostrar que, fuera cual fuera la evolución sociológica, lo que está claro es que el estereotipo de hombre del XIX debía ser un hombre valiente y que esta era la principal característica para que un ser humano mereciera llamarse hombre.

Analizamos, pues, a continuación, todas estas figuras masculinas de las que hablamos. Lo que sigue es nuestra propuesta de interpretación de lo que representó cada uno de estos subgéneros masculinos en los arrabales del Río de la Plata basándonos en los textos que nos hablan de ellos y en las imágenes tanto reales como imaginarias que hemos podido consultar.

\subsubsection{Un precedente: el gaucho.}

Decía El Chúcaro que «el hornero es como el gaucho, anda siempre cerca del hombre, pero nunca se deja agarrar». ${ }^{113}$ Él era un gran conocedor del campo y entendía bien cómo vivían sus protagonistas. En estas pocas palabras ya nos deja claro que lo que definía al gaucho era su vida en libertad y, por supuesto, su modo de vida configuró su carismática personalidad. Antes

${ }^{113}$ León Benarós, «La vida de El Chúcaro contada por él mismo», Folclore n 9 (1962): 9, acceso el 20 de febrero de 2021, https://ahira.com.ar/ejemplares/folklore-no-9/. 
de comenzar nuestra descripción del personaje y de analizar cómo fue visto por la intelectualidad argentina en diferentes momentos debemos aclarar algunos aspectos.

El gaucho fue recuperado como representante de la identidad nacional en un momento intelectual crucial en Argentina. Frente al positivismo de la Generación del 80 que había puesto todos sus esfuerzos en crear un estado moderno a base - fundamentalmente- de atraer extranjeros del mundo que ellos consideraban civilizado, surge en la primera década del siglo XX una generación de intelectuales que busca algo más profundo que no tenía que ver solo con cuestiones de economía. Querían conseguir la identidad nacional que quizá nunca habían tenido antes del brote inmigratorio porque no estaban constituidos como pueblo — la vida en la Pampa y las Provincias era dispersa y más individualista - y más tarde porque la gente que poblaba Buenos Aires era principalmente extranjera.

Así, empezaron a crear símbolos como el gaucho, que tantas veces había sido repudiado por su supuesta barbarie. Ahora lo veían como el máximo representante del sentir nacional, de lo que nunca habría que haberse perdido y alrededor de su figura se creó una mitología y unas leyendas que superaron con creces la realidad. Pero, ¿cómo surge y cómo vivió el gaucho?

Walt Whitman nos dice en su poema Salut au monde!:

«I see the Brazilian vaquero,

I see the Bolivian ascending mount Sorata,

I see the Wacho crossing the plains, I see the incomparable rider

of horses with his lasso on his arm,

I see over the pampas the pursuit of wild cattle for their hides. " ${ }^{114}$

Según nos cuenta Borges el gaucho tiene más relación con el género tango de la que parece. Para él, como para nosotros y para El Chúcaro, el

114 Walt Whitman, «Salut au monde!», The Walt Whitman archive, acceso el 10 de febrero de 2020, https://whitmanarchive.org/published/LG/1881/poems/85. 
gaucho y el compadrito están íntimamente relacionados. Sobre la alusión al gaucho de Whitman, para el escritor bonaerense, está íntimamente ligada con el tango:

«Esta mención del gaucho no es casual, ya que el gaucho viene a ser uno de los personajes del tango, aunque posiblemente no conoció nunca su música y no bailó ese baile». ${ }^{115}$

En las Cuatro conferencias de Jorge Luis Borges sobre el tango encontramos unas reflexiones acerca de por qué el gaucho está emparentado con el tango; esto es, a través del compadrito. Los dos trabajaban con animales, por ejemplo. El compadre - habla Borges de compadrito como uno de los tipos de compadre- no se veía como compadre sino como criollo y el prototipo de criollo era el gaucho. Por ello cree que, aun sin pretenderlo ni quererlo, el gaucho influyó en el tango por su estrecha relación con el compadrito.

Quizá esta visión del gaucho forma también parte de esa mitología que se creó alrededor de toda la historia del tango y en general de la vida rioplatense, pero es interesante para este trabajo por lo que ya ha sido expuesto: el relato que ha perdurado es el mitológico, y continuará siéndolo hasta que el nuevo y más historicista adquiera el peso necesario para sobreponerse a más de cien años de historia. Además, El Chúcaro, nuestro referente, nos lo presenta como tal.

Asimismo, según nos cuenta Gabriela Silvestri en La Nueva Historia Argentina $^{116}$ el gaucho se va a imponer como constitutivo de la identidad nacional, al igual que posteriormente sucederá con el tango. Será el gaucho y no el indio por poseer aquel mayor grado de fuerza y definición que este. Vemos aquí clara la relación entre el folclore y el género urbano. A pesar de establecerse entre ellos una clara diferenciación y hasta cierta rivalidad, ambos se convirtieron en símbolos de lo criollo, de lo nacional y, en definitiva,

21.

115 Jorge Luis Borges, El tango. Cuatro conferencias. (Barcelona: Ed. Lumen, 2016),

${ }^{116}$ Gabriela Silvestre, «El imaginario paisajístico en el litoral y el sur argentinos». La Nueva Historia Argentina, tomo 4 (Buenos Aires: Editorial Sudamericana, 1998), 224. 
de lo propio de ese territorio. Dos caminos que se unen para cumplir una importante función: configurar el carisma de una sociedad que creía haber perdido sus referentes por mirar demasiado al otro lado del Océano Atlántico.

A pesar de esta aseveración que muestra al gaucho y la pampa como símbolos nacionales, hay que tener muy en cuenta que cuando existía el gaucho tal como lo describimos en este estudio aún no era un símbolo, y mucho menos nacional. La sociedad rioplatense pensaba únicamente en el progreso, y cuando el proceso industrializador estaba ya completamente asumido en una sociedad multicolor, el argentino y el uruguayo comenzaron a establecer símbolos nacionales. Recordemos que esta época romántica asiste a la creación de los nacionalismos a nivel mundial y en Argentina se consagrará durante los años del Centenario.

Es conocida la mitología creada por Borges acerca de lo que llamó secta del cuchillo y del coraje, donde describe los tipos masculinos que tratamos de analizar en este estudio. Esa leyenda borgiana nos habla de hombres de honor a quienes no les importa matarse en una pelea, pero siempre cumpliendo las normas, y sin levantar la voz. Mitología o no, es el reflejo de una sociedad que vivió las últimas décadas del siglo XIX y principios del siglo $X X$, que estaba protagonizada siempre por hombres y cuyas vidas conforman el contexto en el que se ha de gestar el tango. El gaucho podría considerarse único precedente de todas estas figuras, así que veamos cómo se desarrolló históricamente.

En tiempos de la colonia, gran cantidad de señores de la corte española viajaron a las Indias animados por las riquezas que de allí llegaban al monarca Felipe II. Fundaron allí grandes ranchos donde convivían con los indios y donde las indias eran «mujeres comunes de todos» ${ }^{117}$. Fruto de estas relaciones nacerían hijos con sangre española y aborigen que darían lugar más adelante a una nueva raza denominada "gaucho". «Criollo y gaucho, pues, no son la misma cosa; en el primero no hay sangre india...». ${ }^{118}$

\footnotetext{
117 Emilio P. Corbiere, El gaucho: desde su origen hasta nuestros días, $2^{\mathrm{a}}$ ed. (Sevilla: Renacimiento, 1998), 21.

118 Ibidem, 31.
} 
El territorio que habita el gaucho ocupa las provincias de Buenos Aires, Santa Fe, Entre Ríos y parte de Corrientes. Al principio eran considerados holgazanes e incluso malhechores y a finales del siglo XVIII la denominación gaucho se refería a pobladores con escasos recursos económicos que trabajan con animales vacunos para obtener sus cueros. Desde sus primeros tiempos se le reconoce como un nómada que emplea una guitarra para, de vez en cuando, entonar cantos propios y ajenos.

Durante el siglo XVIII fue también protagonista de contrabandos fronterizos entre territorio portugués y español cuyo principal fin era el mercado del cuero. Era una época de preocupación para el gobierno español en el Río de la Plata, entre otros problemas, por la competencia portuguesa a través del contrabando. En este contexto se fragua a finales del siglo una figura fundamental para la cultura rioplatense que se llamó gauderio — del latín gaudere, gozar- o gaucho. Este fenómeno social renuncia a encajar socialmente en la colonia a cambio de su libertad.

«Es el agente del comercio de cueros: matarife de vacas y arriero de yeguadas y vacunos, arrimado a veces a alguna estancia, pero reacio a la voluntad de amos y capataces». ${ }^{119}$

El caballo llegó con los españoles y enseguida el gaucho se mostró como un hábil jinete. Los gauchos tenían un modo de vivir muy particular, por ello se convirtieron en un grupo social perfectamente diferenciado. Eran nómadas, ni siquiera el hecho de tener una familia les hacía permanecer más del tiempo necesario en un mismo lugar. Vivían en absoluta libertad y la apreciaban por encima de todo. Se dedicaban sobre todo a la doma de caballos. Uno de los rasgos que puede ayudarnos a comprender por qué el cambio de vida que se produjo en el siglo XIX en el Río de la Plata afectó tanto al gaucho es su escaso interés por el dinero y lo material. Sólo necesitaba su caballo y poco más. El estado moderno se basa en principios capitalistas donde la propiedad privada pasa a ser protagonista. Los bienes materiales

119 Jorge Emilio Gallardo, El nacimiento del gaucho (Buenos Aires: Idea viva, 2000), 
superan a la necesidad de organizarse como sociedad, se limita el territorio, los precios de la carne suben, se limita la caza al empezar a tratar químicamente el cuero. Todo esto supone una degeneración en la vida del gaucho.

Nos interesa también el análisis del gaucho como hombre por considerarse el protagonista de una época en la que la población y la sociedad era mayoritariamente masculina. Como dice Fernando O. Assunçao, «no sólo en número, sino en carácter». ${ }^{120}$ Se daba esta circunstancia especialmente en la campaña, donde el hombre se ocupaba del cuidado del ganado y transitaba solo, sin familia ni ley.

Hablando de las ropas empleadas por los gauchos y su afán por lo colorido y lo llamativo nos dice Assunçao:

«... un afán por lo espectacular o llamativo, en lo que a los hombres y su vestuario se refiere, muy propio de quien es el arquetipo cultural de una organización super-patriarcal, del tipo clan varonil, donde el hombre es el eje y el brazo, en una palabra, lo es todo y donde la mujer, ocupa un lugar menos que secundario, lo más del tiempo el de un catalizador dinámico, un excitante apenas». $^{121}$

El protagonista de la novela de Ricardo Güiraldes Don Segundo Sombra dice acerca de su recién logrado trabajo en una finca: «Había empezado mi trabajo y con él un gran orgullo: orgullo de dar cumplimiento al más macho de los oficios». ${ }^{122}$ El gaucho debe comportarse como hombre, según la consideración que del género había en la época. Esto significaba básicamente demostrar coraje y valentía, pero nunca debilidad. De hecho, el mismo personaje de la novela de Güiraldes reconoce en una escena de especial dureza que «si fuera una mujer lloraría desconsoladamente». ${ }^{123}$

Podría parecer contradictorio si tuviéramos en cuenta la escasa expresión sentimental que definió al hombre durante mucho tiempo, pero es

\footnotetext{
${ }^{120}$ Fernando O. Assunçao, Pilchas criollas (Buenos Aires: Editorial Emecé, 1991), 20.

121 Ibidem.

122 Ricardo Güiraldes. Don Segundo Sombra (Madrid: Ediciones Cátedra, 1998), 118.

123 Ibidem, 141.
} 
importante saber que el gaucho conocía la música, la guitarra, los estilos de la época. Como ya he apuntado en párrafos anteriores el gaucho integraba la música en su día a día mediante coplas conocidas o cantos improvisados. Se dice que era su manera de expresarse ya que se caracterizaba por ser parco en palabras. Sería interesante preguntarse también si este interés por la música o este canal empleado para la expresión de la vida cotidiana y de sus cuitas constituyen también una muestra de su exacerbada masculinidad. Creemos que sí, puesto que como podemos ver, por ejemplo, en los primeros minutos de la película que comentaremos más adelante, Santos Vega, la guitarra acompañaba una especie de lucha dialéctica entre dos payadores y siempre uno de los dos resultaba vencedor. Al igual que sucederá en la ciudad con el compadrito y sus dotes como bailarín, la capacidad del gaucho para ganar en la payada es otra excusa para que un hombre se sienta orgulloso de sí mismo. El gaucho, además, es protagonista de hazañas exclusivamente masculinas como la guerra. Fue muy útil al gobierno en las luchas contra los indios, también en la Guerra de Independencia contra España. A pesar de haber jugado este importante papel para su país, quedaría socialmente discriminado.

Sin embargo, de nuevo en este trabajo nos vemos enredados en la madeja de la mitología y la historia. No hubo un solo tipo de gaucho - lo que parece de sentido común - y las características de cada uno dependían del lugar y el tiempo que le tocaba vivir. Carlos Vega hablaba acerca de la imposibilidad de establecer un prototipo de gaucho, dependiendo su caracterización de la época y el lugar exactos en los que vivió. Continúa Vega describiendo la mujer que acompañaría ese hipotético gaucho y el hogar que compartirían, su rancho. Para este musicólogo argentino esta figura idealizada, este símbolo es completamente falso e incapaz de representar a los hombres y mujeres del campo. Sería simplemente una imagen sesgada de su modo de vida y de las circunstancias que lo rodearon. Según Vega, no se puede hablar de un único modelo de gaucho:

«La creación del modelo es un acto espontáneo de voluntad colectiva aceptado sin examen por las generaciones de tradicionalistas, y así se 
reproduce en el orden privado, la premeditada ejemplaridad de los próceres históricos que con carácter formativo difunde la docencia oficial». ${ }^{124}$

Otros autores han hablado de la imposibilidad de establecer un modelo único al hablar del gaucho. Esto es lo que escribe Matías Emiliano Casas en la revista Historia y Memoria a propósito de la conocida como Década Infame de Argentina, los años 30. Según este autor, durante estos años el imaginario gauchesco tuvo gran fuerza en gran cantidad de publicaciones:

«En ese contexto, la circulación del imaginario gauchesco como referencia a lo autóctono y lo "argentino" fue incrementando a lo largo del período. Sin embargo, la figura del gaucho lejos de alcanzar una caracterización única iba experimentando diversas atribuciones de sentido». ${ }^{125}$

Compartimos la visión de Vega y de Casas de no poder unificar los rasgos de tantos hombres por el hecho de dedicarse a la misma actividad o habitar el mismo territorio. Sin embargo, es indudable que el gaucho se convirtió en un símbolo de la vida fuera de la urbe y la característica de estos habitantes de la Pampa que nos interesa en este trabajo es básicamente una: su virilidad, entendida esta última según los criterios de mediados del siglo XIX. En esto sí podemos generalizar y es un rasgo que se aplica al gaucho como tipo social y, en general, al hombre de su época y de muchas más. Lo que lo diferencia del resto del género masculino del siglo XIX es su particular modo de vida al margen de la sociedad organizada como tal y de la influencia europea.

El gaucho fue un personaje que incomodaba a aquellos dirigentes que querían modernizar Argentina. Nos referimos — por citar un caso relevantea Domingo Faustino Sarmiento, presidente de la República entre 1868 y 1874.

124 Olga Fernández Latour de Botas, «Folclore y tradicionalismo durante la presidencia de Alvear. Tradiciones regionales y tradicionalismo nacional», Institución Ferlabó, 31 de marzo de 2010, acceso el 20 de junio de 2021, http://ferlabo.com.ar/folklore-ytradicionalismo-durante-la-presidencia-de-alvear-tradiciones-regionales-y-tradicionalismonacional.html

125 Matías Emiliano Casas, «Representaciones y publicaciones sobre el gaucho argentino en la década del treinta. Entre la identidad nacional, el campo literario y las estrategias comerciales», Historia y Memoria, 11 (Universidad Pedagógica y Tecnológica de Colombia, julio-diciembre, 2015): 151-176. 
Para el pensamiento liberal el indio y el gaucho eran símbolo y síntoma de atraso, violencia y pobreza, como podemos leer en la Nueva Historia Argentina ${ }^{126}$. Por otro lado, es interesante conocer la opinión de uno de los más influyentes intelectuales de los años 60 y 70 del siglo XIX en la política argentina: Vicente Fidel López. En un número del año 1871 de La revista del Río de la Plata podemos leer:

«Las ideas y la experiencia del Presidente sobre filosofía histórica son poco sólidas y demasiado superficiales para que les de ascenso. Donde don Faustino ve un caballo y la llanura de los campos, se refriega los ojos y ve con pavor la barbarie; donde ve un hombre a pie y una fábrica, ve la civilización y la organización social. Pero no es así. Lo más que podríamos concederle, es que hay bárbaros de a pie y bárbaros de a caballo. Porque esas grandes ciudades imperiales que él cree focos de civilización (porque son focos de industria) son también focos de una barbarie espantosa, de una barbarie mil veces más atroz y despiadada que la nuestra. Esa civilización de la industria acumula la miseria con la barbarie en el fondo de la sociedad, y cuando el cráter revienta, París, la ciudad del sibaritanismo industrial, el emporio de la cultura de los de a pie, se convierte en un desierto con más bárbaros y más forajidos que todos los que se abrigan en el desierto de nuestras campañas. Londres tiene bajo sus plantas el mismo fango, y un célebre Romancista de nuestros días, ha trascripto escenas históricas de matanzas, no muy lejanas, que no tienen ejemplo sino en los países de la barbarie industrial»." ${ }^{127}$

Este extracto de La Revista del Río de la Plata es una muestra no sólo de que el mundo caminaba y se obligaba a una modernización algo forzada pasando por encima de los intereses de la tierra, sino también de la importancia del gaucho - junto al indio- como representación de un modo de vida que ya nunca más recuperaría el Río de la Plata.

126 Alberto R. Lettieri, «De la "República de la Opinión” a la "República de las instituciones"» en La Nueva Historia Argentina. Tomo 4 (Buenos Aires: Editorial Sudamericana, 1998), 97-160.

127 Vicente Fidel López, «Fisonomía del mes», La Revista del Río de la Plata (1871): 159-200, acceso el 20 de enero de 2021, http://www.cervantesvirtual.com/nd/ark:/59851/bmc9c7p1. 
«El gaucho se divide en dos clases. El hombre ignorante, rústico, campesino, que no recibió los beneficios de la instrucción ni la cultura europea; enamorado de las selvas enmarañadas, los llanos desolados o las montañas silenciosas; (...) La otra clase es la del gaucho de salón, civilizado en su exterior y perfeccionado en sus cualidades nativas; hábil en intrigas y supercherías, polilla política y árbitro infalible para resolver los problemas de la patria, según sus peroratas y sus auto-elogios. Ambicioso de mando y engreído de títulos, pleiteísta y enredador...». ${ }^{128}$

En mi opinión, esta "polilla política" de la que nos habla Corbiere es uno de los tipos sociales de los que hablaremos más adelante: el guapo, el compadre o el compadrito. Es decir, otro tipo de persona diferente al gaucho del campo, que de algún modo se ha integrado ya en la ciudad y que ejerce labores de "defensa" política en apoyo a políticos locales.

El tipo social que deriva directamente del gaucho sería el guapo y, como veremos más adelante al hablar de él, uno de sus rasgos más característicos era la lealtad y el respeto que en todo momento mostraba hacia su jefe, hacia el caudillo al que servía y — ¿por qué no? — hacia sus rivales en la lucha cuerpo a cuerpo. Al analizar el modo de ser del gaucho nos damos cuenta de que tiene unos valores morales muy firmes y esto se irá perdiendo en las generaciones posteriores, pero en el guapo y su lealtad a los políticos que lo sostienen aún es claro.

En cuanto al fuerte carácter del gaucho debemos recordar que éste se fue desarrollando paralelamente en relación directa con el devenir histórico de su territorio. Este campero - y también las chinas, madre, hija o hermana de gaucho- entró a formar parte del ejército del Virreinato y la Colonia. Pero eso no le dio una mejor consideración social, seguía siendo un mero adorno en las aldeas de españoles donde era claramente repudiado. No fue hasta la Revolución de 1580 — primera muestra pública de las intenciones del pueblo criollo de arrebatar el poder a los españoles - cuando el gaucho dio muestras de un asentado carácter. Es la época en la que Juan de Garay fundó la ciudad

${ }^{128}$ Emilio P. Corbiere, El gaucho: desde su origen hasta nuestros días, $2^{\mathrm{a}}$ ed. (Sevilla: Renacimiento, 1998), 25-26. 
de Buenos Aires, con el nombre de Ciudad de la Trinidad, donde en 1536 Pedro de Mendoza había fundado un fuerte con el nombre de Real de Nuestra Señora Santa María del Buen Ayre.

Un testimonio acerca del gaucho dice lo siguiente en 1789:

«Su vida, siempre monótona, se reduce a salir al campo, siempre a caballo, y correr de rancho en rancho, sin cuidar jamás de su manutención propia, seguro de encontrarla en la primera parte donde se apee, pues cualquiera recibe hospitalidad franca». ${ }^{129}$

Durante la época conocida como la Autonomía de las Provincias (18201852) surgen estadistas como Moreno y Rivadavia, generales como Belgrano y los Balcarce, entre otros. Pues bien, de estos tipos sociales surgirán en generaciones posteriores hombres envalentonados y con ansias de mando. Gobernantes que repudiaban a colaboradores instruidos para poner en sus cargos a individuos maleables, más o menos analfabetos. El gaucho encontró un cómodo lugar en estas circunstancias y llegó a creerse un hombre superior y a pensar que esa labor era su destino. De nuevo encontramos a un hombre nacido natural y socialmente en el campo que tiene que buscarse un lugar en la ciudad cuando ésta está a punto de experimentar el cambio más rápido y significativo de su historia.

Lugares tan importantes como Córdoba, Santa Fe o Santiago del Estero fueron gobernadas por caudillos prácticamente analfabetos. Rosas ${ }^{130}$, por ejemplo, se identificó con el gaucho y lo utilizó para reprimir violentamente las acciones de sus adversarios. Corbiere nos explica cómo fue un caudillo salteño, Güemes, el que dio auténtica fama al gaucho:

«Aquellos hombres siguieron a su jefe por el afecto que les inspiraba, sin considerar su empresa militar de patriotismo libertario; no cedieron a la "leva" sino a la superhombría del caudillo que era ecuánime, noble y guapo, siendo

129 Sara Parkinson de Saz, «EL gaucho en la vida y literatura argentina», Don Segundo Sombra (Madrid: Ediciones Cátedra, 1998), 29. 1835 y 1852.

130 Juan Manuel de Rosas fue gobernador de Buenos Aires entre 1829 y 1832 y entre 
para sus soldados más padre que jefe, entre los cuales ocupaban lugar de mando oficiales argentinos y extranjeros» ${ }^{131}$.

Hablando de los gauchos que formaban parte de la caballería de Rosas, Corbiere nos explica también que los gauchos porteños obedecían las órdenes del caudillo con «unción religiosa» ${ }^{132}$. De nuevo vemos aquí la lealtad como valor fundamental en la moral gauchesca.

Conocemos rasgos del gaucho también por las observaciones que nos han transmitido extranjeros que conocieron aquel territorio durante el s. XIX. Por ejemplo, Charles Darwin hablaba de ellos como personas corteses, hospitalarias, modestas y audaces, aunque también decía que derramaban demasiada sangre en sus duelos. ${ }^{133}$

Corbiere habla también de este carácter afable del gaucho cuando afirma:

«La generosidad del gaucho, fue en su tiempo, la de todos los hombres buenos sin distinción de razas ni pueblos, herencia de los primitivos pobladores de la tierra que no sabían de ingratitudes, practicada hasta como simbolismo de un amor fraternal que va desapareciendo quebrado por la tiranía del dinero». ${ }^{134}$

Autores como Assunçao distinguen dos etapas en la gauchería ${ }^{135}$ : la primera correspondería a aquella en la que el gaucho es dueño de sí mismo, domina el territorio que habita subido a su caballo. Es el amo de la edad del cuero y no depende de nadie. En la segunda etapa ya estaría viviendo las consecuencias de la propiedad privada, el gaucho ya no es dueño de su propio destino. Sigue siendo un rudo y habilidoso jinete, pero ya no está «en

131 Emilio P. Corbiere, El gaucho: desde su origen hasta nuestros días. (Sevilla: Renacimiento, 1998), 140.

132 Ibidem, 142.

133 Sara Parkinson de Saz, «EL gaucho en la vida y literatura argentina» en Don Segundo Sombra. (Madrid: Ediciones Cátedra, 1998), 30.

134 Emilio P. Corbiere, El gaucho: desde su origen hasta nuestros días (Sevilla: Renacimiento, 1998), 185-186. 1984), 54

${ }^{135}$ Fernando Assunçao, El tango y sus circunstancias (Buenos Aires: Ed. El Ateneo, 
el ejercicio pleno del libre albedrío, para vaguear por campos "de nadie"». ${ }^{136}$ En esta época de guerras, en la que la sociedad lucha por conseguir un mundo de orden y de paz, el mundo libre del gaucho se desvanece, es una figura incompatible con una vida de orden, de defensa de lo común, del estado, en definitiva.

Así, el gaucho debía someterse, si quería continuar en el campo, al trabajo organizado, los terrenos privados y el hogar. Y si la opción era abandonar la relativa libertad que aún le podía brindar la vida en la campaña, se tendría que acercar a la ciudad. Algunos así lo hicieron, afincándose en las zonas suburbanas a medio camino entre el campo y la urbe - rurbanas las llama Assunçao- donde la industria había decidido instalar los primeros saladeros allá por los últimos años del s. XVIII. Los gauchos tenían el perfil que se necesitaba en ese momento en las zonas industrializadas, ya que eran hombres duros capaces de realizar tareas complicadas como matar, cuerear, descuartizar o rodear, especialmente en los momentos anteriores a la llegada de las máquinas.

El tipo de actividades que realizaban en las orillas de la ciudad recordaba en cierta manera a las multitudinarias vaquerías de la campaña, pero el lugar, la urbe, a pesar de tratarse de zonas que en definitiva eran más rurales que urbanas, supuso para el gaucho un cambio radical y una pérdida de libertad que probablemente nunca superó. En la segunda mitad del siglo $\mathrm{XIX}$, con la llegada del ferrocarril a la pampa, el telégrafo, los frigoríficos $\mathrm{y}$, en general, las máquinas agrícolas y ganaderas, el gaucho cambia radicalmente su modo de vivir. Se convierte en agricultor y ganadero.

Como anotamos en el título de este subcapítulo, este personaje que acabamos de describir constituye en sí mismo el precedente de todos estos tipos de hombre que vivirán la gran época del cambio en el Río de la Plata. La figura del gaucho no desaparece, pero da paso al guapo, al compadre, al compadrito y todos aquéllos que quisieron remedarlo. El Chúcaro nos habla solo del compadrito, pero como veremos más adelante en muchas ocasiones

136 Ibidem, 55. 
se emplean diferentes nombres para designar a una misma persona. Leemos referencias a compadres, guapos, malevos, compadritos y en general otros personajes entre los que nos cuesta encontrar diferencias.

En cuanto a la relación del gaucho con la música podemos hablar desde dos puntos de vista: el de la música popular y el de la música académica. El gaucho conocía la guitarra e improvisaba sus cantos, como ya hemos explicado. Esta figura del improvisador y guitarrista campero se conoce como payador. El hombre del campo se expresaba a través de estas improvisaciones. Era prácticamente analfabeto por lo que no se puede afirmar que tuviera una literatura escrita, pero integraba en su día a día cuentos, canciones e historias que contaba al mismo tiempo que transmitía sus valores morales. Estos cantos e historias constituían su folclore.

Si hablamos del gaucho en la música académica tenemos que hablar de Alberto Williams y su obra El Rancho abandonado. Existe cierta polémica a la hora de considerar esta composición para piano de 1890 como la que realmente inaugura —después de otros intentos anteriores- el nacionalismo argentino. Obras como la ópera Pampa de Berutti de 1897 o el poema sinfónico también titulado Pampa que Saturnino Berón compuso en 1887 están también entre las candidatas a representar la música nacionalista argentina. Independientemente de esta polémica lo que nos interesa es que esta música tomó elementos de la vida del gaucho para crear una música siguiendo el modelo europeo. Melanie Plesh en su artículo «El rancho abandonado. Algunas reflexiones en torno a los comienzos del nacionalismo musical en la Argentina», concluye que lo que se pretendió con la composición de estas obras fue dar dignidad a la música folclórica empleando elementos de la música académica europea:

«Llegamos así a descubrir lo que la definición no se atreve a decir, esto es, no basta combinar voluntariamente el material rural con el académico porque no cualquier material académico es apropiado para ello. Al folklore hay que "elevarlo", "darle dignidad artística", "depurarlo", "estilizarlo", etc., y para eso no sirven ni la guitarra ni los rudimentos de la armonía tonal. Hacen falta los instrumentos de larga tradición académica $y$, además, una elaboración armónica, contrapuntística, textural, etc., que eleve su nivel de complejidad, alejándolo de las simplezas rurales. 
Esta necesidad de un nacionalismo aséptico, sin "malos olores" ni desprolijidades de factura refleja una postura más propia de la generación del '80 que de la moderna musicología, y un eurocentrismo que sería saludable que hoy, en el marco de la conmemoración del $V$ Centenario, lográramos superar». ${ }^{137}$

Recordemos que estamos en la época en la que Europa era modelo de civilización en contraposición con la barbarie de la que hablaba Sarmiento. En este sentido el gaucho también es alzado como representante fundamental de la identidad argentina, aunque este reconocimiento llegue más tarde. El hecho de que en el ámbito de la música académica se compusieran obras englobadas dentro de lo que conocemos como nacionalismo musical argentino teniendo al gaucho como protagonista, es una muestra más del alzamiento de este hombre del campo como símbolo de la identidad nacional.

Por otro lado, aunque el gaucho no produjera literatura escrita, sí sucedió al revés. A partir del siglo XIX el gaucho será protagonista de infinidad de obras literarias entre las que destaca fundamentalmente Martín Fierro de José Hernández, pero también obras del uruguayo Bartolomé Hidalgo, Hilario Ascasubi o Estanislao del Campo. Muy relevante también fue la obra de Eduardo Gutiérrez Juan Moreira, aunque algunos -entre otros, Ricardo Güiraldes, autor de Don Segundo Sombra- consideraron una aberración suponer que Moreira era un prototipo de gaucho. Esta obra fue llevada al teatro, a donde llegó también la figura literaria del gaucho con gran fuerza. El uruguayo Florencio Sánchez fue otro de los dramaturgos que llevó este personaje a la representación escénica.

En cuanto a la relación directa del gaucho con el tango podemos afirmar que lo que los une de un modo más cercano es el hecho de haberse convertido ambos en símbolos nacionales:

«Despite a strong official campaign after 1880 to modernize Argentina by throwing the country's borders open to foreign influences and emulating

137 Melanie Plesch, «El rancho abandonado. Algunas reflexiones en torno a los comienzos del nacionalismo musical en la Argentina», La historia de la payada (1992), acceso el 20 de enero de 2021, http://anaforas.fic.edu.uy/jspui/handle/123456789/43632?mode=full. 
European high culture, by 1900 the gaucho and the tango had both begun to emerge -albeit at different rates— as alternative symbols of the nation». ${ }^{138}$

El cine también se hizo eco de la vida del gaucho y su representación es especialmente interesante en dos películas que procedemos a comentar: Nobleza gaucha y Santos Vega. De la primera existen dos versiones, una de 1915 y otra de 1937. La segunda fue estrenada en el año 1971.

La historia del cine en Argentina comienza, como en casi todos los países, con breves grabaciones de escenas cotidianas. La primera película considerada el primer largometraje argentino fue estrenada en 1914 bajo el título de Amalia y en 1933 se presenta Tango!, la primera película sonora de ese país. Nobleza gaucha —la primera versión - es el único film argentino que se conserva en $35 \mathrm{~mm}$ y quiere mostrar la nobleza del gaucho como principal rasgo moral del mítico hombre de campo. Las partes que no se conservan fueron sustituidas por breves textos extraídos del poema Martín Fierro de José Hernández. De hecho, el guión del largometraje se basa en este poema y otro titulado Santos Vega, del poeta Rafael Obligado. Aquí se ve perfectamente definida la primera figura que presenta El Chúcaro: el gaucho, su rutina del campo, sus momentos de ocio y, fundamentalmente, su carácter y su código moral.

Recordamos que han pasado solo cinco años desde la celebración del Centenario de la Revolución de mayo de 1810 que le dio la independencia a Argentina. Es el momento en el que se gestan todos aquellos elementos que quieren aportar una identidad al territorio y tiene lugar, especialmente, la elevación del gaucho como símbolo fundamental de lo criollo. El objetivo de Nobleza Gaucha en sus dos versiones es evidente: dejar claro que ese rasgo, la nobleza, es lo que mejor representa a estos hombres del campo.

Es innegable que la película dirigida por Sebastián M. Naón en 1937 tiene un argumento más trabajado, que los espacios, vestuarios y diálogos están mucho más definidos pero la clave de la historia es el final, cómo

${ }^{138}$ Brian Bockelman, «Between the Gaucho and tha Tango: Popular Songs and the Shifting Landscape of Modern Argentine Identity, 1895-1915», The American Historical Review, Vol. 116, 3 (2011): 578. 
resuelve el gaucho un conflicto con el patrón. En la primera película, una vez que se sabe ganador, no se aprovecha del contrincante, sino que le ayuda, aunque al final el desenlace para el estanciero es el peor. En la penúltima escena de la segunda versión, después de que el gaucho perdone al patrón y retomen su antigua relación de amistad, uno de los personajes principales le dice: «había olvidado tu nobleza gaucha» ${ }^{139}$.

Si ampliamos los rasgos del gaucho a la vida del campo en general, vemos en estas dos películas perfectamente expuesta la dicotomía campociudad. Al comienzo del largometraje más moderno el patrón, que viene de Buenos Aires, califica a los gauchos como vagos y al llegar a la estancia, no muestra escrúpulos al prescindir de trabajadores que llevan toda la vida allí trabajando, que incluso le cuidaron a él en su infancia, con tal de intentar mejorar la economía de la casa. En el juicio moral que al espectador se le puede plantear al terminar de ver la película, vemos más factible que se incline por defender la honrada y dura vida del campo frente al superficial y desmoralizado punto de vista urbano. Esta defensa a ultranza de lo antiguo frente a lo moderno, del campo frente a la gran Buenos Aires y el ensalzamiento de la figura del gaucho es fundamental en esta época donde se intentan recuperar valores con los que poder identificar al pueblo rioplatense.

Otra de las películas más representativas al respecto de la vida del gaucho en la llanura fue Santos Vega, dirigida por Carlos Boscosque. Al ver esta película se toma conciencia de lo lento que pasaba el tiempo en aquella época, nada que ver con la vida acelerada de la vida urbana. De nuevo, las orillas serían un paso intermedio. El rasgo del protagonista de la película que más se destaca es la valentía. Santos Vega regresa a su hogar sabiendo que las autoridades lo persiguen y él no presenta el menor ademán de esconderse. No tiene miedo, se muestra en público a menudo y acude a la pulpería donde, además, se une al baile. Más tarde, mostrará su coraje vengando el asesinato de su enamorada.

139 Sebastián M. Naón, Nobleza Gaucha (Productora Argentina de Films, 1937). 
Desde la aparición a finales del siglo XIX del cine, en Argentina se realizaron grabaciones relacionadas con hecho históricos como, por ejemplo, la Revolución de Mayo. Se representaron en pantalla los héroes y personajes más relevantes de la historia del territorio. Es a partir de Nobleza Gaucha que el hombre de la Pampa comienza a protagonizar largometrajes dando lugar a lo que se conoce como el cine gaucho, que se convirtió en un medio más para dar a conocer al mundo las virtudes de su héroe nacional más carismático.

A continuación, analizaremos las figuras del guapo, el compadre y el compadrito. Pero antes de hacerlo debemos reiterar que en algunas ocasiones se habla de ellos en los mismos términos. Es decir, con los mismos rasgos se define a las tres figuras. Sucede por ejemplo con el capítulo dedicado al compadrito en la obra de Ernesto Sábato, Tango, discusión y clave. En este texto se habla indistintamente de compadre y compadrito, por ejemplo. Lo que recogemos con gran interés de esas páginas son dos alusiones a la hombría como rasgo destacado del compadre o compadrito. Así, Sábato alude a una cita de Manuel Pinedo (seudónimo de Jorge Luis Borges):

«... Mientras haya un clavel en la oreja del cuarteador, mientras perdure un tango que sea feliz y pendenciero y límpido, mientras que desde la altura del pescante el carrero gobierne taciturno el lento río de los tres caballos, y mientras el coraje o la venganza prefieran al revólver tumultuoso el tácito puñal, estará el hombre...». ${ }^{140}$

Asimismo, nos remite a Fernando Guibert para mostrar el complejo de inferioridad que provocaba a veces en el compadrito una angustia que lo hacía volverse más altanero:

«El compadrito quería ser el hombre que no podía alcanzar porque sabía que no lo era, eso lo angustiaba y cuando más crecía su sombra entre otros, más ganas le entraban de ser aún más compadre. Así, desesperado, probándose a sí mismo, amontonaba hazañas tras hazañas, es que asistía al drama de su

${ }^{140}$ Ernesto Sábato, Tango, discusión y clave (Buenos Aires: Editorial Losada, 1963), 62. 
impotencia vital a pesar de la hombría impaciente y estudiada, asistía al drama de su inferioridad pese al inmoderado levantar de sus hombros y su mirar de costado, su frase o su silencio perdonando». ${ }^{141}$

A pesar de esa a veces casi imposible diferenciación entre los diferentes tipos masculinos, nosotros presentamos los rasgos que, para nosotros, según nuestra interpretación de las fuentes, definirían cada uno de ellos.

\subsubsection{El guapo.}

Entramos ahora en el análisis de los tipos masculinos que derivan de la figura del gaucho. Uno de los rasgos que los caracterizará a todos ellos será la evidente competitividad entre unos y otros en sus encuentros cotidianos. No hablamos de conflictos específicos, sino en una especie de enfrentamientos simbólicos con cierta carga de violencia y que tienen que ver con la jactancia de sus dones como varón:

«Instead, in the context of the popular classes at this time, adult male identity was shaped by the face-to-face competition for masculinity taking place in urban homosocial spaces of sociability. A significant proportion of the men spending the day in these spaces was young and single. Indeed, as Sandra Gayol's study demonstrates, the status of being a man involved competition based on physical or symbolic violence». ${ }^{142}$

Si consultamos el Diccionario de la Real Academia de la Lengua Española encontramos en la voz guapo ocho acepciones. Nos interesan especialmente las que nos lo describen como 'Animoso, bizarro y resuelto, que desprecia los peligros y los acomete', 'hombre pendenciero y perdonavidas' y 'en estilo picaresco, galán que festeja a una mujer'. ${ }^{143}$

Por otro lado, en los diccionarios de Lunfardo de José Gobello y Oscar Conde encontramos, respectivamente, las siguientes definiciones: 'Valiente;

141 Ibidem, 63.

142 Pablo Ben, «Plebeian Masculinity and Sexual Comedy in Buenos Aires, 18801930», Journal of the History of Sexuality, Vol. 16, 3 (2007): 444.

143 RAE, Diccionario de la lengua española, acceso el 20 de enero de 2021, https://dle.rae.es/guapo. 
valentón. Resistente para el trabajo'144 y 'hombre pendenciero y perdonavidas' ${ }^{\prime 145}$. Además, Conde unifica las definiciones de guapo y compadrito.

En nuestra tesis el guapo es el primero en recoger el testigo del gaucho, pero no necesariamente desde un punto de vista estrictamente cronológico, sino en lo que tiene que ver con su relevancia social. Los textos consultados nos hablan del guapo como un hombre respetable, leal. También valiente y corajudo, pero que emplea estas "armas" solo en caso de necesidad y en circunstancias plenamente justificadas. Sin embargo, enseguida se le confunde con el compadraje en general. Por ejemplo, en el poema de Evaristo Carriego que sigue:

«El barrio le admira. Cultor del coraje,

conquistó, a la larga,

renombre de osado,

se impuso en cien riñas entre el compadraje

y de las prisiones salió consagrado.

Conoce sus triunfos y ni aún le inquieta

la gloria de otros, de muchos temida,

pues todo el Palermo de acción le respeta

y acata su fama, jamás desmentida.

Le cruzan el rostro, de estigmas violentos, hondas cicatrices, y quizás le halaga

llevar imborrables adornos sangrientos:

caprichos de hembra que tuvo la daga.

La esquina o el patio, de alegres reuniones, le oye contar hechos, que nadie le niega:

¡Con una guitarra de altivas canciones

él es Juan Moreira, y él es Santos Vega!

Con ese sombrero que inclinó a los ojos,

¡Con una guitarra de altivas canciones

144 José Gobello, Diccionario Lunfardo (Buenos Aires: Ed. A. Peña Lillo, 1975), 102.

145 Oscar Conde, Diccionario etimológico del lunfardo, $3^{\mathrm{a}}$ ed. (Buenos Aires: Ed. Taurus, 2019), 177. 
cantando aventuras, de relatos rojos, parece un poeta que fuese bandido! Las mozas más lindas del baile orillero para él no se muestran esquivas y hurañas, tal vez orgullosas de ese compañero que tiene aureolas de amores y hazañas. Nada se le importa de la envidia ajena, ni que el rival pueda tenderle algún lazo: no es un enemigo que valga la pena pues ya una vez lo hizo caer de un hachazo. Gente de avería, que guardan crueles brutales recuerdos en los costurones que dejara el tajo, sumisos y fieles le siguen y adulan imberbes matones. Aunque le ocasiona muchos malos ratos, en las elecciones es un caudillejo que por el buen nombre de los candidatos en los peores trances expone el pellejo Pronto a la pelea pasión del cuchillo que ilustra las manos por él mutiladas, su pieza, amenaza de algún conventillo, es una academia de ágiles visteadas.

Porque en sus impulsos de alma pendenciera desprecia el peligro sereno y bizarro, ¡Para él la vida no vale siquiera/ a sola pitada de un triste cigarro! Y allá va pasando con aire altanero, luciendo las prendas de su gallardía, procaz e insolente como un mosquetero que tiene en su guardia la chusma bravía. ${ }^{146}$

De alguna manera el tipo humano que representa el gaucho muere y renace en las orillas. Aquí nacerá una serie de hombres en cuyas vidas estará presente el afán de libertad y el trabajo duro mezclados con el nuevo ambiente

146 Evaristo Carriego, «El guapo», El Guapo, acceso el 20 de enero de 2021, https://www.biblioteca.org.ar/libros/1176.pdf. 
de los límites de las ciudades. Los arrabales y las orillas tan nombradas en este trabajo son, simplemente, aquellas partes de la ciudad a las que aún no había llegado ni el ferrocarril ni la electricidad. El centro frente a la periferia. En estas zonas se desarrollará un grupo social en el que se mezclarán criollos e inmigrantes, se relacionarán en los trabajos y en los conventillos. El gaucho que dejó el campo también se acercó a estos lugares. Su mundo cambia radicalmente, pero él no, por lo que en su traslado necesitará encontrar nuevos medios de subsistencia. Ya encontró un lugar, las orillas de la ciudad, y ahora necesita una ocupación. Su valentía y su estricta moralidad lleva a algunos de ellos a ser guardaespaldas de los políticos. Establecen una relación con ellos de extremada lealtad y en cierto modo no dejan de ser -al menos no del todo- hombres libres. Sólo se unen a su jefe, sólo se deben a él, el resto no importa. En este ámbito el guapo, como será conocido este prototipo masculino, emplea sus armas más poderosas: el coraje y el cuchillo.

El guapo es la primera de estas figuras que nos encontramos a finales del siglo XIX en ese estado de incipiente modernidad. En el poema de Evaristo Carriego con el que comienza este capítulo se muestran ya perfectamente las características principales de este tipo de hombre: es valiente, respetado por todos, mujeriego y, en ocasiones, protector de políticos. Vemos en el texto también una referencia a la guitarra, que nos lleva a pensar en este instrumento musical como nexo de unión entre el gaucho y el guapo. Además del cuchillo, como nos propone El Chúcaro en su coreografía, el gaucho y el guapo comparten según la opinión de Carriego, su relación con la música. Encontramos también una descripción y representación clara del personaje en la película Un Guapo del 900, dirigida por Leopoldo Torre Nilsson en 1960 y la obra de teatro Juan Moreira, de Eduardo Gutiérrez cuya publicación original data de 1889. Como podemos ver en estos dos ejemplos, el guapo no se casa, usa cuchillo, viste de negro y normalmente tiene una muerte prematura.

Leemos en un interesante artículo que analiza la película de Torre Nilsson una descripción de este prototipo masculino:

«El tipo del guapo (con numerosos antecedentes en el escenario rioplatense desde Juan Moreira) tiene dos perfiles: uno histórico, como personaje 
plebeyo, antisocial e indeseable, de personalidad primitiva e instintiva, con rasgos de "compadrón", quien presta sus servicios a un caudillo político de turno y "le gana" las elecciones "a punta de cuchillo". Y el perfil mítico con dimensión heroica, tan frecuente en la literatura argentina de esta época (los guapos de Borges, por ejemplo, y otros), asentado en dos sistemas inalterables: "la ética del coraje", presente en la obra a través de actitudes y expresiones de los personajes, y "el código de honor", basado en la subordinación de la libertad individual a un valor considerado superior: la lealtad, que a su vez exige y genera lealtad del caudillo al que sirve". "La pieza presentará el conflicto de identidad de Ecuménico (explícito en las últimas escenas de la obra), que lo enfrentará con la búsqueda de su verdadero ser de guapo, apoyado en una nueva lealtad y un nuevo sistema de valores que privilegie la libertad a la obediencia servil, la verdad a la mentira, la fidelidad a sí mismo y la justicia a la sujeción a un código externo y arbitrario». ${ }^{147}$

Así, en esta película vemos cómo el personaje sufre una transformación en su concepción de la vida y la libertad, pero no peligra su antiguo código moral —la lealtad, el coraje - simplemente descubre además la libertad individual. Necesita expiar su culpa por haber cometido un asesinato aun sabiendo que el código moral del guapo y el haber sido cometido su crimen para defender la dignidad de su caudillo, lo eximiría de pagar por él.

En cuanto a la referencia a la novela de Eduardo Gutiérrez, Juan Moreira, un año más tarde nos cuenta Javier Gasparri:

«...en la novela de Eduardo Gutiérrez, y correlativamente en la figura que de Moreira allí se representa, puede leerse la aparición del guapo como transfiguración del gaucho: el "guapo Juan Blanco", más enjoyado, sobrecargado y glamoroso de lo que ya era Moreira (un gaucho sobresaliente), marca una suerte de travestismo gauchesco que en su

147 Laura Rosana Scarano, «Hacia una nueva ética del coraje: un guapo de 900 de Samuel Eichelbaum», Revista Letras, 37, Universidad Nacional de Mar del Plata (2010):187. 
exuberancia hiperbólica no puede sino llamar la atención cuando, paradójicamente, lo que quiere con ese travestismo es "ocultarse"». ${ }^{148}$

Compartimos con Gasparri la apreciación del guapo como imitador o heredero del gaucho, pero no tanto su origen literario. Sin embargo, nos interesa más su exposición del modo en el que se confunden unos tipos masculinos con otros y cómo resalta la importancia del ideal masculino que todos representan. Establece ya una escala masculina en la que todos los tipos serían imitadores del Guapo y la diferenciación entre uno u otros sería su grado de «fidelidad al original» ${ }^{149}$.

En opinión de Borges, «el guapo era simplemente un hombre que estaba listo a pelear, con uno o con muchos». ${ }^{150}$ Para él, el tipo que influye directamente en el tango no es exactamente el guapo, sino el que lo imita, el que vive de las mujeres y vive también peleas a cuchillo. Quizás esté hablando aquí del compadrito. En ese caso estaríamos de acuerdo con él. Al igual que Borges, pensamos que es el compadrito el que protagoniza los ambientes tangueros del arrabal de los años 80 del s. XIX según nos lo cuentan los narradores del relato clásico. El guapo sería su modelo o también podríamos decir que la figura del guapo va perdiendo fuerza si tenemos en cuenta ciertos rasgos -especialmente éticos o morales - y da lugar a los tipos masculinos que analizamos de aquí en adelante.

Se dice que Borges creó una mitología inventada que nada tenía que ver con la realidad, pero a nosotros nos parece que sintetizó —de un modo brillante- en la secta del cuchillo y del coraje los rasgos de una parte de la sociedad rioplatense: la masculina. En todo caso, de la aportación de este escritor hablaremos más detalladamente en capítulos posteriores.

\footnotetext{
148 Javier Gasparri, «Che varón. Masculinidades en las letras de tango», Caracol, 2 (2011): 177, acceso el 23 de abril de 2021, https://www.revistas.usp.br/caracol/article/view/57660/60715. 149 Ibidem, 179.

150 Jorge Luis Borges, El tango. Cuatro conferencias (Barcelona: Ed. Lumen, 2016), 57.
} 
Nos interesa sobremanera describir cómo iban vestidos estos hombres, puesto que la vestimenta es uno de los rasgos que han llegado hasta la actualidad y que aún podemos ver en espectáculos de tango.

Generalmente vestían pantalón abombillado con trencilla, un pañuelo apretado en la garganta y sombrero. Estas prendas serán empleadas también por compadres, compadritos, malevos y ha contribuido a crear una estética que, como tratamos de demostrar en este trabajo, perdura en la actualidad.

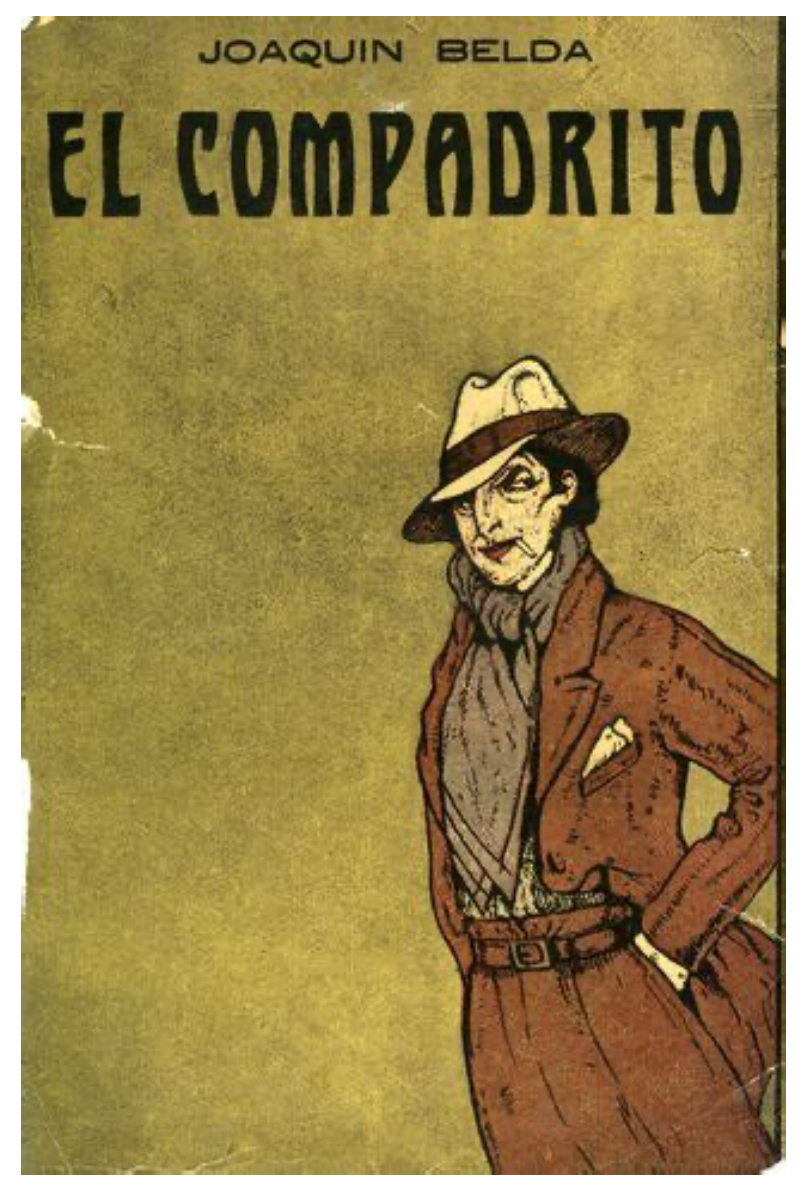

Figura 2. Portada del libro de Joaquín Belda, El compadrito.

No hemos encontrado diferencias en las ropas del guapo, del compadre o del resto de modelos masculinos a los que hacemos alusión. Al igual que lo que sucede con los rasgos que caracterizan su personalidad, en este sentido están unos muy cerca de otros. Parece que unos intentan imitar a los otros, pero la sociedad va cambiando. El esfuerzo físico que el gaucho necesitaba para llevar a cabo sus tareas en el campo nada tiene que ver con la vida de la ciudad, ni tampoco en la soledad del campo existían los peligros de las orillas donde los conflictos serían más habituales. También la inmigración 
podría haber jugado un papel importante en esta cuestión. La relación con gente diferente, la mezcla de lenguas y de costumbres hace que inevitablemente se diluyan las propias. En definitiva, cada uno de estos prototipos va heredando ciertas cualidades de los anteriores, pero también desechando otras muchas.

\subsubsection{El compadre.}

De nuevo recurrimos a un texto de Jorge Luis Borges para introducir nuestros párrafos dedicados a otro de estos prototipos masculinos, el compadre:

«Hombre de las orillas: perdurable.

Estaba en el principio y será el último

Estará donde un trágico boliche,

sin revocar, humilde y colorado,

ante el vértigo inmóvil de los huecos

aventura su caña y su baraja;

estará donde un hombre de voz áspera,

al compás de seis cuerdas trabajosas,

frangolle con desdén una milonga

más trivial y modesta que el silencio,

pero que hable de vida, tiempo y muerte;

estará donde el último retrato

de Irigoyen presida austeramente

el vano comité que clausuraron

con rigor las virtuosas dictaduras,

negando al pobre el ínfimo derecho

de vender la libreta del sufragio;

estará donde esté el despedazado

suburbio, los calientes reñideros

donde giran los crueles remolinos

de acero y aletazo, grito y sangre». ${ }^{151}$

151 Manuel Pinedo [seud], «El compadre», El compadrito. Selección de Jorge Luis Borges y Silvina Bullrich (Buenos Aires: Emecé editores, 2000), 41. 
En este poema Borges escrito en 1943 el escritor habla del compadre, y para ello emplea palabras y conceptos clave que nos llevan al tango, al puñal, a Nicanor Paredes, Amalio Reyes, al barrio, a la cárcel y, en definitiva, al hombre.

Según Martínez Estrada el compadre es un personaje que la Colonia llevó al Río de la Plata. Lo sitúa entre el guapo y el guarango, asimilando cualidades de estas dos figuras masculinas. Del guapo ya hemos hablado y el guarango es descrito en el Diccionario de la Real Academia Española como 'incivil'. En concreto Estrada nos dice:

«Por algunas notas confina con aquella zona del hombre bravo, íntegro, solitario; por otras, aparece como variedad del hombre sin carácter, facticio e incompleto que es el guarango». ${ }^{152}$

Todos los tipos masculinos que se describen en este trabajo tienen la característica común de ser considerados seres antisociales. A este respecto es interesante la reflexión de Martínez Estrada en la que habla del compadre como un ser en claro retraso con respecto a la marcha de la sociedad. Supondría esto una incapacidad para integrarse del todo y no una elección personal como parecía claro en el guapo. La violencia con que el compadraje afrontaba los conflictos podría ser entonces muestra de un resentimiento fruto de esta inferioridad.

Esto apoyaría nuestra teoría de que las figuras masculinas entre el guapo y el malevo van descendiendo escalones morales y esto sería un símbolo de la desmoralización o relajación moral —entendiendo ésta como pérdida progresiva de peso de los valores morales de los que se parte- que supuso el pensamiento liberal en la sociedad no sólo argentina o uruguaya, sino universal.

Horacio Salas en su libro El tango incluye un Estudio preliminar donde Ernesto Sábato nos habla también del compadre:

152 Ezequiel Martínez Estrada, Radiografía de la Pampa (Madrid: Consejo Superior de Investigaciones Científicas, 1991), 121. 
«El compadre es el rey de este submundo. Mezcla de gaucho malo y de delincuente siciliano, viene a ser el arquetipo envidiable de la nueva sociedad: es rencoroso y corajudo, jactancioso y macho. La pupila es su pareja en este ballet malevo; juntos bailan una especie de pas-de-deux sobrador, provocativo y espectacular. Es el baile híbrido de gente híbrida: tiene algo de habanera traída por los marineros, restos de milonga y luego mucho de música italiana. Todo entreverado, como los músicos que lo inventan: criollos como Ponzio y gringos como Zambonini». ${ }^{153}$

Algunos como Fernando Assunçao ${ }^{154}$ consideran como un tipo socialmente definido únicamente al compadrito y esta denominación tendría sus raíces en el vocablo compadre empleado entre la gente corriente referido a cierta filiación de padrinazgo. Sin embargo, en este trabajo hablaremos del compadrito como una figura que deriva del compadre suavizando en cierta medida sus rasgos o siendo estos solo mera apariencia.

Se considera al compadre un ladero de personas de relevancia social o política cuyos descendientes —con mucha frecuencia- apadrinaban. También podríamos verlo como un guardaespaldas de poca monta. Seguiría los pasos del guapo, pero en él podemos observar una mayor laxitud moral. Se hacen favores, son valientes, pero su función en la sociedad no está ya tan determinada.

Miguel D. Etchebarne ${ }^{155}$ describe cómo el compadre no encuentra un contexto especial en el que mostrar su coraje y cómo esta fuerza se va acumulando y convirtiendo en enfermedad. Cambiará la valentía necesaria en ciertas ocasiones por la provocación. Deriva también de este hecho la tristeza común en estos hombres y que, en su opinión, encontró su expresión en el género tango. Concretamente dice:

«El compadre siguió, como su antecesor el gaucho, rindiendo culto al coraje. Pero la existencia cotidiana no le permitía, como había ocurrido con aquel, poner a prueba su potencia en el combate con el semejante o con la

${ }^{153}$ Horacio Salas, El tango (Buenos Aires: Ed. Planeta, 1995),15. Ateneo), 59.

154 Fernando O. Assunçao, El tango y sus circunstancias (Buenos Aires: Ed. El 155 Ibidem, 60. 
naturaleza. Se iba, así, almacenando en el compadre una fuerza que, acumulada, se transformó en enfermedad. Para curarse con el desahogo de la hombrada nació la provocación. Pero esto no conformó nunca la naturaleza nacida para mejor fin. De ahí su tristeza oscura e indescifrable, mezcla de arrepentimiento personal y de resentimiento social que halló su expresión en el tango». 156

Si tenemos en cuenta lo que nos dicen Etchebarne o Estrada y lo que hemos dicho del Guapo en páginas anteriores podemos extraer dos conclusiones: la primera es que en esta cita se habla del compadre en los mismos términos que antes se hablaba del guapo y, por lo tanto, tendríamos aquí un ejemplo más de la confusa aplicación de estos términos. En segundo lugar, Etchebarne define al compadre simplemente haciendo alusión a su coraje y, en general, a su hombría. No nos cuenta nada acerca de su trabajo u otros aspectos relacionados con su modo de vivir. Lo mismo sucede con los textos de Borges o Estrada.

Además, a diferencia de la cantidad de veces que los textos populares ${ }^{157}$ consultados hablan de guapos y compadritos, el compadre tiene un menor protagonismo. Sí encontramos en muchos textos palabras derivadas de compadre como compadrear o el empleo de ese vocablo como adjetivo. No sucederá así con la palabra compadrito.

En el diccionario de Oscar Conde ${ }^{158}$, este experto en lunfardo nos define el compadre como "gaucho asentado en la ciudad o sus arrabales caracterizado por un modo particular de comportarse, hablar y vestir». Una segunda acepción es «hombre provocativo, fanfarrón e insolente». Además, lo relaciona con el vocablo español con el que se nombra el «padrino de bautizo de una criatura respecto del padre o la madre o la madrina de ésta». También lo identifica con el compadrito, aunque en la voz compadrito, como

156 Ernesto Sábato, Tango, discusión y clave (Buenos Aires: Editorial Losada, 1963), 57.

157 Nos referimos a publicaciones periódicas como Caras y Caretas o poemas y cuentos tradicionales. En los artículos académicos, a pesar de no llegar a tener el peso del compadrito, el compadre tiene una mayor presencia.

158 Oscar Conde, Diccionario etimológico del lunfardo, $3^{\mathrm{a} e d .}$ (Buenos Aires: Ed. Taurus, 2019), 112. 
veremos, aporta algún rasgo distinto. Esto apoya nuestra idea de que no siempre fueron la misma persona, aunque sus rasgos pronto se confundieron.

Como conclusión, se puede definir el compadre como un habitante del arrabal, que emplea las maneras de los guapos pero cuyas actividades no tendrían la relevancia - sobre todo política- de estos. Emplean la fuerza y muestran su coraje si las circunstancias lo obligan y dan muestras de una estricta moralidad que se manifiesta principalmente en la lealtad hacia su familia y amigos.

En cuanto a la vestimenta - teniendo en cuenta las imágenes consultadas en prensa de la época o las películas que se han encargado de describir este personaje- no encontramos, como ya hemos dicho, diferencia entre la que empleaban guapos, compadres y compadritos. De hecho, si por las imágenes fuera, probablemente no distinguiríamos un tipo de otro.

Si nos centramos en su relación con el tango, no podremos, una vez más, distinguirlo del guapo o del compadrito, de quien nos ocuparemos a continuación. El compadre es el menos nombrado en los textos que relacionan el tango y los suburbios y son pocas las referencias que hemos encontrado que los relaciona. Una es el comentario que ya hemos mencionado de Martínez Estrada, quien opina que el tango fue una vía de escape a través de la que este hombre acomplejado convirtió su frustración en hombría. Otra tiene que ver con la relación entre el inmigrante y sus hijos y el compadre. Según M. Cecilia Hwangpo, el compadre es el denominador común de tres elementos determinantes en la configuración de la Buenos Aires cosmopolita:

«Los inmigrantes, debido a su condición socioeconómica, no podían vivir en los barrios deseados y terminaban en los conventillos de los barrios pobres, en la orilla -el arrabal. En estos lugares que habitaban tanto los inmigrantes como sus hijos, y con el deseo de argentinizarse, observaban a los compadres que eran sus vecinos más visibles. Esta coexistencia diaria permitió que los 
inmigrantes y sus hijos imitaran al compadre, y en la mayoría de los casos, terminaban convirtiéndose ellos mismos en compadres». ${ }^{159}$

Hwangpo recoge el relato clásico de la historia del tango y centra su estudio en el sainete, forma teatral que reconoce como un medio de comunicación de la época y que, en su opinión, recoge este de manera hiperbólica este tipo masculino originario de las orillas y lo convierte en un personaje central del costumbrismo de la época. Establece, por tanto, un mismo origen para el compadre y el tango: los suburbios. Al mismo tiempo, describe como rasgos de este hombre orillero el empleo del lunfardo, el empleo de ropa llamativa y el interés por la bebida, el cante y el baile. Este estudio nos interesa, además, porque afirma, como nosotros, que el compadrito será un imitador del compadre y del guapo y estas son las principales características que remedará de sus antecesores:

«Es emulador del donjuanismo, presuntuoso, bailador y hablador; y tiene aficiones de 'señorito' por su inclinación por el tango». ${ }^{160}$

Este análisis del compadre en el sainete emplea también el término "superhombría"161 al hablar de las cualidades por las que este hombre era reconocido popularmente. Simon Collier, además, presenta al compadre como heredero del gaucho y de nuevo destaca como uno de los rasgos heredados una ostentosa masculinidad. ${ }^{162}$

Nuestra visión recoge estas ideas y damos un paso más allá reconociendo ese concepto de masculinidad como base fundamental del símbolo que se gestó a través de la exageración de los rasgos de todos los prototipos masculinos que estamos describiendo y que se verá reflejado en el género tango.

159 M. Ceclilia Hwangpo, «El compadre: un tipo porteño liminal y espacial», Revista de Crítica literaria latinoamericana, Año XXXV, 70, Lima-Hanover (2009): 257.

160 Ibidem, 258.

161 Ibidem, 266.

162 Simón Collier, «The popular roots of the argentine tango», History Workshop, 34 (1992): 94-95. 


\subsubsection{El compadrito.}

Continuamos nuestro recorrido por los representantes masculinos del suburbio rioplatense en la segunda mitad del siglo XIX. El último escalón en el camino que estamos planteando desde la figura del guapo - $\mathrm{O}$, si tenemos en cuenta la figura que hemos establecido como precedente, desde el gaucho- sería el compadrito. Este sería el tipo masculino del que más se habla cuando se trata el tema de los orígenes del tango y de los arrabales. Parece que todos los rasgos de los que hemos hablado hasta ahora están personificados en el compadrito $\mathrm{y}$, definitivamente, es el término más empleado al hablar en la actualidad de los protagonistas del arrabal.

De nuevo recurrimos a la mayor autoridad en Lengua Castellana para buscar la definición oficial del término. Podemos encontrar en el Diccionario de la Real Academia tres acepciones de este personaje:

1. 'Perteneciente o relativo al compadrito, a sus costumbres, ropas, etc. Tiene un deje compadrito al hablar'.

2. 'Dicho de una cosa: Que tiene cierta vistosidad. Un sombrero compadrito. Una melena compadrita'.

3. 'Tipo popular, jactancioso, provocativo, pendenciero, afectado en sus maneras y en su vestir'.

Leyendo estas tres definiciones parece claro que el compadrito debió de haber sido un tipo en cierta medida exagerado en sus maneras, alguien que llamaba la atención tanto por su aspecto como por su modo de vivir.

José Gobello en su Diccionario Lunfardo y Oscar Conde en su Diccionario Etimológico de Lunfardo en alguna de sus acepciones no hacen distinción entre compadre y compadrito ${ }^{163}$. Sin embargo, ambos - Gobello en la voz compadre y Conde en ambas - nos aportan un detalle importante. Cuando hablaban del compadre en su primera acepción lo relacionaban con el gaucho, suponiendo una especie de evolución que partía de este. Pero al

\footnotetext{
163 José Gobello, Diccionario Lunfardo (Buenos Aires: Ed. A. Peña Lillo, 1975), 50.
} 
hablar del compadrito lo definen como un joven suburbano que imita las actitudes de los compadres. Esta definición nos muestra al compadrito como un tipo más moderno que el compadre, es ya un producto totalmente urbano. Este hecho nos lleva de nuevo a situar estos tipos sociales en una línea cronológica que pronto se irá difuminando hasta que apenas podamos distinguir unos de otros. De nuevo comprobamos que compadre y compadrito no fueron lo mismo. Dice Antonio Pau que:

«El compadrito tiene algo de señorito orgulloso y peleón. Lleva un cuchillo al cinto, como muestra de su fiereza, y a veces lo saca: ve ofensas en cualquier mirada y se venga haciendo brillar el filo a la luz de las tabernas». ${ }^{164}$

El compadrito hereda el carácter peleón y el cuchillo, pero no tanto los motivos por los que emplearlo. Es un personaje más que una persona, su personalidad se refleja en sus ropajes, en sus gestos, en los lugares que frecuenta y en un cierto resentimiento, no tanto en un marcado carisma ni una fuerte personalidad. En algunos lugares lo definen como hombre del bajo pueblo, vano, engreído y fachendoso. Individuo del suburbio porteño que imitó al compadre. Borges y Bullrich hablan de él como el plebeyo de las ciudades y del indefinido arrabal, como el gaucho lo fue de la llanura o de las cuchillas $^{165}$.

Fernando Guibert en su descripción del contexto vital del compadrito afirma que su vida revela un retraso con respecto al mundo que le toca ${ }^{166}$, y esto nos recuerda a lo que Martínez Estrada nos contaba acerca del compadre. Como vemos de nuevo, las figuras analizadas son descritas muchas veces con rasgos comunes hasta el punto de que muchas veces confundimos unas con otras. Quizá la realidad, como sucede a menudo, no es tan estricta en las diferenciaciones como lo que se escribe sobre ella. También sería lícito pensar que estas tres figuras - guapo, compadre y compadrito- fueron contemporáneas y que simplemente se diferenciaban en

\footnotetext{
${ }^{164}$ Antonio Pau, Música y poesía del tango (Madrid: Trotta, 2001), 9.

165 Jorge Luis Borges y Silvina Bullrich, El compadrito (Buenos Aires: Ed. Emecé,

${ }^{166}$ Fernando Guibert, El compadrito y su alma (Buenos Aires: Editorial Perrot, 1957).
} 2000), 11 
lo estricto de su moralidad y la profundidad de sus rasgos. Sin embargo y como ya hemos reiterado en varias ocasiones, nuestra opinión es que en algún momento sí tuvo que haber diferenciación entre unos y otros. Andrés M. Carretero nos describe así el compadrito:

«El compadrito es un personaje de la Capital Federal que reúne los defectos y virtudes del porteño nato: bravucón, suelto de boca, despectivo para todo aquello que no sea propio de su ciudad y su ambiente, socarrón, irónico y cachador para los que desconozcan las características de la ciudad y sus códigos de comportamiento» ${ }^{167}$.

Eduardo P. Archetti, por su parte, destaca el coraje y la fuerza entre sus rasgos más apreciados:

«Se trata de un elegante seductor, irresistible para las mujeres y admirado por su coraje, fuerza física y capacidad de embaucar cuando la ocasión lo requiere». ${ }^{168}$

Si tenemos en cuenta las opiniones de quienes hablaron de ellos, lo que nos cuentan las letras de tango y los textos literarios - de ambos hablaremos con detalle más adelante- podemos afirmar que las tres "armas" que le permiten al compadrito sobrevivir y mostrarse como el gran protagonista del arrabal son el cuchillo, su maestría en el baile y la mujer de la que de algún modo se cree dueño. Le complace mostrarse agresivo para, así, marcar su territorio que será también el territorio en el que bailará con esa mujer a la que, en algunos casos, explota actuando como un despreocupado proxeneta, ni siquiera como un hombre de negocios. Otras veces simplemente es descrito como un hombre de cierta apariencia y andares pero de escasa relevancia social. Es obvio pero necesario resaltar que esta última acepción del término compadrito no protagoniza tantos textos ni letras de tango, por lo que podemos afirmar que tampoco influyó demasiado en el relato de la historia

167 Andrés M. Carretero, El compadrito y el tango (Buenos Aires: Ediciones Continente, 2019), 12.

${ }^{168}$ Eduardo P. Archetti, «Masculinidades múltiples. El mundo del tango y del fútbol en la Argentina» en Daniel Balderston y Donna J. Guy (comps.), Sexo y sexualidades en América Latina, (Buenos Aires: Paidós,1998). 
de esta música urbana. Los cronistas prefirieron las aventuras del hombre jactancioso que explotaba a las mujeres y se exhibía con ellas —o gracias a ellas- a través de la danza, en concreto, del tango.

Si quisiéramos añadir otro personaje que podría parecerse al compadrito pero que supondría una degradación más en nuestro camino entre el gaucho y el arrabal sería el malevo. Dice Antonio Pau comparándolo con el compadrito: «El malevo es más salvaje. Su degradación es mayor». ${ }^{169}$

Esta degradación de la que venimos hablando tiene como causa principal el proceso de relajación moral que implicó el cambio de la vida rural a la urbana. La relativa libertad que ofreció la aparición de la ciudad en el mundo occidental, un lugar donde no todo el mundo se conoce, donde se respeta más el individualismo de sus habitantes, hizo que las normas arraigadas durante tanto tiempo en la vida rural se relajaran y dieran un respiro a la vida en común. Sucedió también por el ritmo acelerado al que se produce este cambio, pero también por la naturaleza de cada una de las rutinas que allí se daban. La vida del campo exige un trabajo esforzado para obtener una recompensa -el sustento, la protección, etc.- en el que se respetan las reglas por el bien común, muchas veces sacrificando el individual. Por otro lado, la vida en el campo es más tranquila y seguramente no tan conflictiva como la de la ciudad, especialmente en sus orillas y esta es otra razón por la que, ante las dificultades y los peligros, las normas morales pasan a ocupar un segundo plano. José Sebastián Tallón nos dice sobre los compadritos:

«...Imitaron la moda de los ricos y se trajearon y acicalaron con un narcisismo exagerado de mujer, evidentemente sospechoso; tomaron el tango y lo llevaron a los medios sexuales obscenos. El contoneo criollo del caminar, que tuvo su origen en los tacos altos, ellos lo hicieron medio tilingo, si no amariconado. $Y$ de la misma manera, a la coreografía del tango le dieron un estilo propio de exageraciones eróticas.... ${ }^{170}$

169 Antonio Pau, Música y poesía del tango (Madrid: Trotta, 2001),9.

170 Juan Sebastián Tallón, «El tango en sus etapas de música prohibida», citado en Tango, Discusión y clave (Buenos Aires: Editorial Losada, 1963), 34. 
Aportamos esta cita de Tallón por considerarla muestra clara de lo que supuso la influencia del relato creado alrededor del compadrito en la coreografía del tango, hasta el punto de ver reflejados en los pasos y gestos de esta danza los rasgos más característicos de estos personajes.

En cuanto a cómo iban vestidos los compadritos nos cuenta Borges en Cuatro conferencias:

"Recuerdo haberle preguntado a un señor cómo se vestían los compadritos en su tiempo. Y me dijo: "Bueno, se vestían como nos vestimos todos ahora", es decir, usaban saco y chambergo; no levita y sombrero de copa; desde luego, usaban pañuelo también. Pero, más o menos, todos ahora nos vestimos como los compadritos de antes". La diferencia -nos cuenta Borgeses que antes existía una clara diferencia entre un compadrito y un señor. Aunque ganara dinero seguiría siendo un "hombre de chambergo, de pañuelo, de saco ajustado, de pantalón campana o pantalón bombilla, de alpargatas, o de taco alto. Había una jerarquía entonces que se ha perdido ahora.» ${ }^{171}$

El hecho de que esa jerarquía de la que habla Borges desapareciera a favor de la vestimenta de los compadritos es otra muestra, en nuestra opinión, de la influencia estética y social de estas figuras en aquellos tiempos.

Otra descripción de la vestimenta del compadrito la encontramos en una cita de El Diario que Hugo Lamas y Enrique Binda incluyeron en su libro El tango en la sociedad porteña:

«...de pantalón corto, botín elástico perfectamente nuevo, camisa irreprochablemente planchada, sombrero chambergo de alas levantadas delante y detrás, melena larga, lustrosa, encaveitada; pañuelo de seda en el cuello de colores chillones, debajo del pañuelo una corbata de nudo elegantemente atada y saco corto». ${ }^{172}$

171 Jorge Luis Borges, El tango. Cuatro conferencias (Barcelona: Lumen, 2016), 2627.

172 Hugo Lamas y Enrique Binda, El tango en la sociedad porteña. 1880-1920 (Stuttgart: Editorial Abrazos, 2008), 57. 
Nos cuenta también Borges que según Ventura Lynch la milonga fue inventada por los compadritos para burlarse del candombe ${ }^{173}$. Este dato es importante en nuestra investigación, ya que la milonga, junto con el candombe y la habanera se presentan como los más importantes antecedentes del tango y si, como dice Lynch, la milonga es una creación del compadrito, aquí tenemos otra razón por la que este se convirtió en símbolo fundamental del origen del tango, y no sólo por su imagen que, como quedará claro al finalizar este trabajo, será recogida en una coreografía que se hará universal. Presentamos a continuación tres fragmentos musicales de candombe, habanera y milonga para dejar constancia del ritmo que caracteriza a cada uno de los tres estilos presentados como principales predecesores del tango rioplatense:

\section{CANDOMBE}

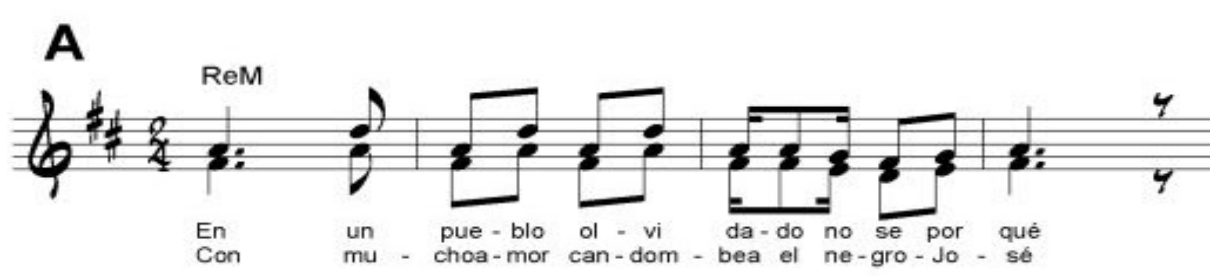

\section{HABANERA}

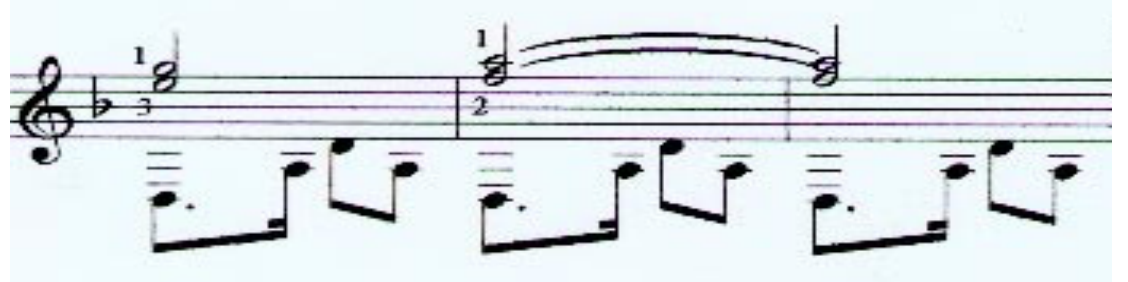

\section{MILONGA}

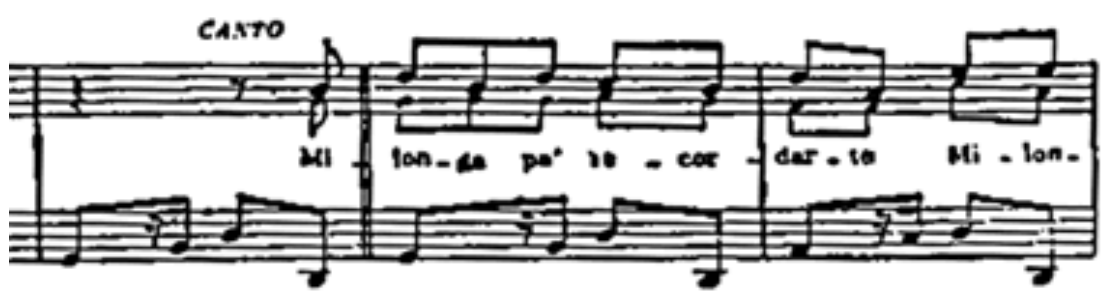

28.

173 Jorge Luis Borges, El tango. Cuatro conferencias (Barcelona: Lumen, 2016), 26- 
Esta tesis de Lynch fue presentada en su libro La Provincia de Buenos Aires hasta la definición de la Cuestión Capital de la República en el año 1883, la recogen los hermanos Bates en su Historia del tango y será secundada por León Benarós en la Historia del Tango que editará Corregidor en 1977. Como ya se ha explicado en el capítulo dedicado a definir el Estado de la cuestión esto formaría parte de ese relato clásico que se ha contado acerca de los orígenes del tango.

Como adelantábamos al hablar del compadre, el compadrito es el personaje al que más aluden los textos cuando hablan de los arrabales. También podemos concluir que es el de maneras más exageradas en el andar, en el vestir y en la relación con los demás. Esta podría ser la razón por la que finalmente la sociedad en general haya devenido en emplear el término 'compadrito' y no 'guapo' o 'compadre' cuando se refiere a estos tipos masculinos.

Hemos encontrado también alguna alusión al compadre moderno, al que nosotros identificamos con el compadrito. Por ejemplo, en enero de 1899, Fray Mocho lo describe así en el semanario Caras y Caretas:

«Es el compadre moderno, el tipo callejero de Buenos Aires, demasiado pobre para paquete y demasiado paquete para pobre, pero preñado de petulancias y de audacias». ${ }^{174}$

Nos cuenta el periodista que las sirvientas del barrio están cansadas de sus empalagosas palabras y que ya ni se inmutan ante su aspecto de falso triunfador. Describe su traje negro, su sombrero perfectamente colocado y su característico modo de caminar. Según Fray Mocho, seudónimo del escritor y periodista argentino José S. Álvarez Escalada, a este personaje no le gusta ni la milonga ni la guitarra, como su antecesor. Damos por hecho que este antecesor es el compadre, a secas.

Estos tres modelos que acabamos de definir representan el esqueleto de la evolución arquetípica masculina de finales del siglo XIX y que

\footnotetext{
${ }^{174}$ Fray Mocho, «El tenorio de ojito», Caras y Caretas, 17 (1899).
} 
protagonizaron también los primeros años del pasado siglo. Se los relaciona fundamentalmente con los arrabales de la ciudad y, sobre todo en el caso del compadrito, con el tango. Ese símbolo en el que se convirtió este tipo masculino reúne los ingredientes descritos en el texto de 1913 titulado Crepúsculo en el arrabal:

«Los domingos enmudecen los golpes de los mazos y de las herramientas, los talleres y las fábricas se cierran; entonces hay un relámpago de alegría, pero una alegría torpe y agria. El acordeón lanza sus voces gangosas y apesadumbradas, la guitarra rasguea melancólicamente. Y los tangos, las jotas, las napolitanas, quiebran el aire crepuscular con su júbilo desgarrado y valentón. Y tal vez se oyen las blasfemias del beodo, o se ve brillar la lámina siniestra del cuchillo pendenciero». ${ }^{175}$

En síntesis y como propone El Chúcaro, el gaucho -parte del gauchaje, por lo menos - tuvo que entrar en las orillas de la ciudad para ganarse la vida y hacerse un hueco en el mundo urbano. A partir de ahí surgen el guapo, el compadre, el compadrito y otros personajes que fueron heredando ciertas cualidades y perdiendo otras por el camino. Del gaucho conocemos cómo era su vida, su trabajo, sus relaciones sociales. Del guapo nos hablan como ladero de los políticos, del compadre sabemos que lo definía una relación familiar y del compadrito solo nos describen sus maneras. De todos conocemos el uso del cuchillo y cierto código moral, cada vez más laxo pero que está reflejado en esa manera de relacionarse socialmente. Esto último es lo que vemos en ciertas coreografías de tango, especialmente como veremos más adelante, en la que hizo al género, universal.

Además de estos tres tipos deberíamos hablar de algunos otros prototipos de la época como fueron el niño bien el taura o el cafishio y, finalmente, el guarango. Para ello recurriremos en un capítulo posterior al vocabulario lunfardo en donde encontramos gran cantidad de referencias a los hombres de la época.

175 Juan Sintierra, «Crepúsculo en el arrabal», Caras y Caretas, 762 (1913). 
En síntesis, el compadre o el compadrito eran el gaucho sin caballo y aquellos gauchos pacíficos con su guitarra, fueron los primeros periodistas como gustaba decir a Don Atahualpa Yupanqui, dado que sus payadas o cánticos reflejaban la queja o sus alegrías en la incipiente ciudad.

Ahora que ya hemos descrito los principales roles masculinos veamos cómo sus vidas, sus intereses y su apariencia fueron recogidos en textos literarios, en el vocabulario lunfardo y en letras de tango. Todos estos personajes fueron agregados al lenguaje culto y en el popular hasta por muchos motivos, pero una de las razones con más peso fue su íntima relación con el tango o, más bien, la manera en que quienes contaron la historia de este género quisieron relacionarlos.

\subsection{La masculinidad en el lenguaje.}

En todo lo escrito hasta ahora en este trabajo están ya planteadas las ideas que ahora nos proponemos concretar. Queda claro que nuestra principal tesis es que los personajes masculinos protagonistas de la leyenda del arrabal son los precedentes estéticos de los protagonistas del tango actual. Nos disponemos a mostrar cómo el lenguaje en sus diferentes manifestaciones es fiel reflejo de ello. Hablaremos de palabras y expresiones habituales en las manifestaciones populares y cultas de diferentes épocas que tuvieron lugar en el Río de la Plata. Se trata de saber de qué manera el lenguaje recogió en sus diferentes acepciones la masculinidad que tanto caracterizó la danza del tango desde sus primeros años hasta la actualidad, y cuyo origen situamos en la primera época de este género con sus protagonistas masculinos como eje central. También tendremos en cuenta el lenguaje posterior para así ratificar nuestra tesis de que esos exacerbados rasgos masculinos fueron lo que las distintas épocas de este género fueron heredando unas de otras hasta llegar a nuestros días.

Se trata de saber si esa masculinidad que hemos descrito, de la que hacían gala especialmente los hombres del momento en que nació el tango en sus maneras y en su relación con los demás y que creemos que se manifiesta en ciertos estilos de tango actuales se ve reflejado en el lenguaje. 
Nos fijamos no solo en las palabras que se empleaban en la vida cotidiana sino también en los textos más trabajados de los literatos y en las que escogía quien debía ponerle letra a un tango o hacerlo nacer de la nada. En cuanto al habla popular queremos reducir el campo al lenguaje del Río de la Plata y por eso, además de las letras de tango y las obras literarias, para analizar el léxico común empleado por el pueblo nos vamos a centrar en aquel que únicamente se emplea en esa zona: el lunfardo. Veamos, por tanto, cómo se manifiesta la masculinidad en los diferentes ámbitos del lenguaje.

En el artículo de la revista Folclore al que ya hemos hecho referencia en páginas anteriores El Chúcaro describe su relación con un compañero del colegio con el que a menudo se peleaba. Después de contar cómo el resentimiento que sentían el uno por el otro duró todo el período escolar el bailarín concluye: «quizá queríamos, mutuamente, medirnos el tamaño de la guapeza». ${ }^{176}$ Esta escena que nos describe el bailarín representa la infancia de muchos hombres, no solo los que vivieron su infancia en los años veinte. Ha sido durante lustros muy habitual que los niños varones compitieran con sus iguales por saber quién era el más fuerte, el más valiente, en definitiva, el más hombre. Casi siempre estas actitudes eran auspiciadas por sus progenitores que a su vez habían vivido lo mismo cuando eran niños. La masculinidad ha sido algo aprendido y muchas veces forzado cuando el infante está llegando a la adolescencia y posteriormente a la edad adulta. En la cita de El Chúcaro vemos, además, cómo en el Río de la Plata esas actitudes ser relacionaban con la figura del guapo. En realidad, después de analizar las figuras masculinas, la guapeza de la que nos habla Ayala es una idea que debemos relacionar no solo con el guapo, sino con cualquiera de los tipos masculinos e, incluso, con cualquier hombre que intente demostrar sus cualidades como tal.

Encontramos también vocablos relacionados con la masculinidad en la manera como algunas personas que lo conocieron describían al bailarín. Como ejemplo podemos leer lo que Suna Rocha escribe al referirse a El

176 León Benarós, «La vida de El Chúcaro contada por él mismo. En diálogos con León Benarós», Folclore, 90 (1962):7. 
Chúcaro y su compañera Norma Viola en el único libro escrito sobre su vida y que recoge textos de sus allegados. Concretamente nos dice: «están en la abrupta virilidad de un malambo» ${ }^{177}$.

Recordemos que en un artículo de Folclore citado anteriormente y que plasma un diálogo con León Benarós, se describe a Santiago Ayala destacando «cierta ensoñativa ternura viril». ${ }^{178}$

Está en el lenguaje de El Chúcaro, en cómo lo describen sus compañeros y los investigadores. Quizá lo que este bailarín veía como rasgo común entre el gaucho y el compadrito no era otra cosa que esa virilidad, la hombría, la masculinidad. Esos rasgos que, de alguna manera, heredaría el tango. Este es uno de los motivos por los que fue tan importante para nosotros el hallazgo de la coreografía Del gaucho al compadrito. No solo nos ofrecía un apoyo teórico, sino que también nos aportó la idea de que lo que realmente se fue manteniendo en épocas diferentes del tango fue lo masculino, independientemente de que la música hubiera sufrido cambios drásticos o los escenarios e incluso sus intenciones fueran totalmente diferentes. El Chúcaro nos aportó el ingrediente que comparte cada etapa de la historia del tango con la anterior y con la que le sigue. Nos permitió establecer el hilo que mantiene unidas las diferencias musicales, rítmicas y conceptuales dentro de un mismo género musical: el tango.

Guapeza, virilidad, viril, términos que encontramos al hablar de El Chúcaro, pero también en las novelas de Eduardo Mallea, en los textos de Borges, en las letras de multitud de tangos y las encontramos también en el léxico lunfardo. En este capítulo demostraremos que ese vocabulario estaba presente en el día a día del Río de la Plata y que así lo recogen los diccionarios, los textos literarios y las letras de tango. Lo heredarán, más tarde, su coreografía y su imagen.

177 Juan Cruz Guillén, Santiago Ayala "El Chúcaro" y Norma Viola. Antes y después. Los irrepetibles (Buenos Aires: Balletin Dance Ediciones, 2015), 51.

${ }^{178}$ Véase nota al pie 79 de este trabajo. 


\subsubsection{Fuentes literarias.}

Sin mentir podría asegurarse que no hay escritor argentino desinteresado del tango o del mundo que lo vio nacer, desde Fray Mocho a Leopoldo Lugones.

Tulio Carella.

Es evidente que un tema tan carismático como el tango no podía haber pasado desapercibido para los literatos argentinos y uruguayos. De hecho, muchos de los protagonistas del tango lo fueron también de la literatura de su época, como es el caso de Carlos Muñoz o Ricardo Güiraldes. Y al contrario, algunos grandes literatos aportaron su granito de arena al repertorio tanguero; en este caso hablamos, por ejemplo, de Evaristo Carriego —considerado por algunos el creador de muchos de los lugares comunes del tango, como los que aquí tratamos-, Jorge Luis Borges o Julio Cortázar.

Lo que nos interesa en este capítulo no es solo presentar las aportaciones de los intelectuales que se interesaron por el tango, sino ver en qué medida y de qué manera la masculinidad estaba presente en sus textos. Veremos cómo palabras como varonil, viril, hombría y otras semejantes ayudan a definir situaciones, pensamientos o personalidades que van configurando el mundo literario de la época. Su punto de vista también es relevante por ese lado mítico de la historia del tango que nos parece tan importante en este trabajo puesto que los poetas $-\mathrm{y}$, en general, los escritores de cualquier género- observan la realidad y escriben sobre ella. No hacen trabajos académicos o de rigor histórico acerca de lo que ven, aunque también se informan y se documentan. Observan, piensan, sienten y escriben. En este trabajo destacamos la capacidad del relato mítico acerca de los primeros años del tango de haber forjado los rasgos más atrayentes de una danza que se universalizó y que actualmente está presente en todo el mundo. A esta universalización contribuyó, en gran medida, lo que lectores de todas latitudes leyeron en las obras de los grandes literatos.

Como ya hemos anotado, el punto hacia el que caminamos en nuestra investigación es la primera parte de La Historia del tango —así es titulada en el audiovisual analizado_ presentada en forma de coreografía por el bailarín 
El Chúcaro y el Ballet Folclórico Nacional. Los protagonistas serán el gaucho y el compadrito y, según nosotros lo entendemos, la masculinidad de la que hacían gala. Al igual que buscamos en la historiografía cómo había sido tratado el estudio del tango, tomamos la propuesta de El Chúcaro como punto en el que queremos que confluyan todos los espacios teóricos que hemos investigado. Analizamos todos los aspectos que creemos imprescindibles para apoyar la teoría de El Chúcaro, o por lo menos, alguna de las ideas que expone. Es el turno ahora de la literatura.

El Chúcaro se centra en el compadrito como eje principal y de él también se habla en la literatura. De él y de la virilidad o la masculinidad de la época. En ocasiones de manera indirecta, pero está absolutamente presente. No sólo presentamos referencias concretas a estos personajes aparentemente protagonistas de los arrabales, sino que nos fijamos en el lenguaje, en concreto, en el vocabulario que emplean estos escritores. Veamos pues qué nos pueden aportar los intelectuales - no solo los que se interesaron por el tango- en lo que tiene que ver con la masculinidad como eslabón que une el gaucho y el compadrito, el tango de los comienzos -0 parte de él- y el actual.

Es obligado comenzar por un autor que, a pesar de haber vivido apenas treinta años, se debe considerar relevante a la hora de hablar del relato del tango como música arrabalera. Se trata de Evaristo Carriego y veremos cómo fue el primero en realizar un retrato del ambiente en el que para nosotros se gesta esa masculinidad que veremos reflejada en la coreografía. Ese contexto del que parte El Chúcaro y que, como veremos también en el capítulo dedicado a las letras, está presente en muchos de los textos tangueros.

Evaristo Carriego fue conocido como el "poeta del suburbio" y estuvo directamente relacionado con los tipos masculinos que darían lugar a la mitología porteña y que según esta protagonizarían los primeros tangos o milongas. Él encontró las posibilidades líricas y literarias de las orillas de Buenos Aires y dedicó su breve vida a escribir poemas y relatos cortos acerca de este mundo. Sus textos fueron habituales de revistas de la época como Caras y Caretas, La Protesta o Papel y tinta. Su primer libro de poesía, de estética modernista, fue publicado en 1908 — sólo cuatro años antes de su 
prematura muerte- y se tituló Misas Herejes. Un año antes habían sido publicados cuatro de sus poemas en la revista satírica Caras y Caretas: «La enferma», «La guitarra», «En otoño» y «El alma del suburbio» ${ }^{179}$. Póstumamente se publicó el libro que contiene este último poema y que también se tituló El alma del suburbio, en el que se aprecia un cambio de estilo y donde se refleja toda esa realidad de los arrabales bonaerenses. Es importante recalcar que el poema que da nombre al libro ya había sido publicado, por lo que no se puede hablar de una evolución posterior hacia temas criollos. Carriego vivió entre 1883 y 1912 así que pudo describir desde los primeros años del siglo $X X$ un mundo que vivió en primera persona y que estaba presente también en su etapa de poesía más modernista. Sin embargo, su representación del arrabal fue posiblemente el comienzo de una literatura que buscaba una identidad nacional en unos perfiles humanos que vivieron un momento de cambio social y económico protagonizado por millones de inmigrantes europeos. Para muchos fue también la fuente fundamental de donde beberían los primeros letristas de tango, especialmente en lo que se refiere a los personajes de la noche.

Carriego vivió en uno de los barrios más antiguos de Buenos Aires, Palermo, donde también vivía Jorge Luis Borges, aunque éste siempre reconoció que no había vivido la vida del barrio, sino que había pasado su infancia en el jardín de su casa bajo la extremada protección de su madre, Leonor Acevedo de Borges. Pero sí conoció el arrabal y a sus protagonistas por -entre otros- Evaristo Carriego. Borges nos habló de lo comprometido que estaba Carriego con su barrio:

«Carriego creía tener una obligación con su barrio pobre: obligación que el estilo bellaco de la fecha traducía en rencor, pero que él sentiría como una fuerza. Ser pobre implica una más inmediata posesión de la realidad, un atropellar el primer gusto áspero de las cosas: conocimiento que parece faltar a los ricos, como si todo les llegara filtrado. Tan adeudado se creyó Evaristo Carriego a su ambiente, que en dos distintas ocasiones de su obra se disculpa

179 Estos poemas aparecen publicados respectivamente en los números 432, 444, 449 y 473 de la revista Caras y Caretas del año 1907. 
de escribirle versos a una mujer, como si la consideración del pobrerío amargo de la vecindad fuera el único empleo lícito de su destino». ${ }^{180}$

En su poema El alma del suburbio está presente ya el día a día de los arrabales y encontramos, como algo cotidiano, el tango bailado entre dos "orilleros":

«En la calle, la buena gente derrocha

sus guarangos decires más lisonjeros,

porque al compás de un tango, que es "La Morocha"

lucen ágiles cortes dos orilleros» ${ }^{181}$.

Junto al tango están en este poema el gringo, el boletín de última hora, el conventillo, el pregonero, los marchantes, el heraldo, las comadres del barrio, los hombres, la cantina llena de parroquianos, los juegos de cartas, el homicida, la tísica, el payador, la mujer del obrero borracho arreglando su ropa, el barrio dormido, las calles desiertas, los vigilantes, perros, gatas, en definitiva, el alma del suburbio.

Carriego nos regala en este poema una fotografía del mundo de las orillas. Nos presenta a todos los personajes: el gringo, el obrero, las comadres... y el tango. Además de una serie de fotografías de las primeras épocas, la leyenda del tango bailado entre hombres se apoya en la séptima estrofa de este poema.

En su poema El Guapo, como hemos visto en el epígrafe dedicado a los tipos masculinos, describe este perfil de hombre del suburbio a la manera en la que lo hará Borges más adelante: como un hombre de coraje, conquistador y cercano a los políticos. Lo compara con gauchos ilustres como Juan Moreira o Santos Vega por su afición a contar sus historias —payadasacompañado de una guitarra.

\footnotetext{
180 Jorge Luis Borges, Evaristo Carriego (Madrid: Alianza Editorial, 2008), 35.

181 Evaristo Carriego, «El alma del suburbio», Caras y Caretas, 473.
} 
El mundo descrito por Evaristo Carriego es el escenario en el que se origina el tango y donde se desarrolla en sus primeros años. Y lo que es más importante, donde sus protagonistas hacen gala de su virilidad y su hombría como carta de presentación. Este podría haber sido el comienzo del relato mitológico del tango, apoyado con fuerza posteriormente por Borges. Carriego pone en el camino un escenario y unos personajes, él muere, pero la función sigue. ¿Realidad? ¿Leyenda? Hemos repetido hasta la saciedad en este trabajo que no es nuestro cometido responder a estas preguntas. Lo que nos proponemos es demostrar que esta "función" aún no ha terminado, que los personajes se han ido renovando, pero se ha conservado una imagen casi permanente, al menos, en gran parte de los protagonistas.

En este recorrido por el tango y la virilidad en la literatura rioplatense debemos hablar también de un gran conocido de Evaristo Carriego: Marcelo del Mazo. Fue, según cuenta Borges, ${ }^{182}$ el amigo más real de Evaristo Carriego. Fue un escritor olvidado, aunque también Borges nos habla de que alguno de sus textos — publicados en 1910 bajo el título Los Vencidos-fue muy famoso. En ese mismo libro encontramos al final el texto titulado "Los bailarines de tango" y dedicado a Federico Mertens, quien junto a Rafael José de Rosa y Antonio Scatasso había compuesto un tango basado en el famoso tema iniciado por Carriego sobre "la costurerita que dio el mal paso".

En este poema del Mazo describe el tango que se baila en los arrabales. Presenta detalladamente los movimientos de los bailarines - un compadre y su compañera- como dos serpientes enredadas que terminan besándose. Habla de su música como la última moda en los arrabales. EI empleo de palabras como 'desvergüenza' o 'impudor' nos transmite la idea de esta danza como algo indecoroso.

«Cuando el ritmo de aquel tango

les marcó un compás de espera, como sierpes animadas

182 Jorge Luis Borges, Evaristo Carriego (Buenos Aires: Alianza Editorial: 2008), 38. 
por un vaho de pasión,

se anudaron y eran gajo

de una extraña enredadera

florecida entre la lluvia

de los bichos del salón.

¡Ahura, m'hija! —aulló el compadre-,

y la fosca compañera

ofreció la desvergüenza

de su cálido impudor

azotando con su carne

como lenguas de una hoguera

las vibrátiles entrañas

de aquel chusma del amor.

Persistieron en un giro,

desbarraron los violines

y la flauta dijo notas

que jamás nadie escuchó,

pero iban blandamente,

a compás los bailarines

y despacio; sin saberlo,

la pareja se besó.

La pareja iba en un ritmo

de pasión y de bravura.

En la almohada del cabello

apoyados los frontales.

Tres manos sobre los hombros

y una garra en la cintura,

era la última moda

del tango en los arrabales». ${ }^{183}$

Carriego y del Mazo son por tanto los primeros autores en presentar el tango en el suburbio.

${ }^{183}$ Marcelo del Mazo, Los vencidos (La Editorial argentina, Buenos Aires, 1910), 139. 
Todo este legado lo recoge Borges y a partir de él el escritor da forma a un exhaustivo análisis no solo de la sociedad argentina sino también de su familia y de su propia personalidad. Este análisis, en lo que respecta a nuestros intereses, se muestra perfectamente resumido en las siguientes palabras: «Y mientras el coraje o la venganza prefieran al revólver tumultuoso el tácito puñal, estará el hombre». ${ }^{184}$

Más que el tango nostálgico que tanto enamoró al mundo entero, a Borges le gustaban las antiguas milongas y los tangos primitivos, anteriores a la aparición y el éxito del tango canción. Identificaba las primeras milongas divertidas con los duelos orilleros, con el cuchillo y con la valentía de los hombres que habían realizado la campaña argentina, los gauchos.

«El tango crea un turbio

pasado irreal que de algún modo es cierto,

el recuerdo imposible de haber muerto

peleando, en una esquina del suburbio». ${ }^{185}$

En Borges el Memorioso ${ }^{186}$ afirma que ha escrito milongas, pero que no podría escribir tangos. Cree que la milonga es lo que la gente sentía y para él el camino de la milonga al tango refleja una gran decadencia.

Fue, lo vamos a comprobar en el desarrollo de este capítulo, el escritor que más líneas le dedicó al tango. En 1965 publica Para las seis cuerdas, un libro en el que recopila once milongas escritas por él mismo cuyos protagonistas serán los guapos, los malevos, el cuchillo, y todas aquellas anécdotas que no pudo vivir por encontrarse encerrado en su jardín del barrio Palermo, esas que más adelante le contarían protagonistas del ambiente como Nicolás Paredes, figura central de una de sus milongas. En ese mismo año Astor Piazzolla pone música a esas milongas y serán interpretadas en

${ }_{184}$ Manuel Pinedo [seud], «El compadre», El compadrito. Selección de Jorge Luis Borges y Silvina Bullrich (Buenos Aires: Emecé editores, 2000), 41.

185 Jorge Luis Borges, «El tango», El otro, el mismo. Obras completas I (Barcelona: RBA Coleccionables, Instituto Cervantes, 2005), 888.

186 Jorge Luis Borges, Borges el memorioso. Conversaciones de Jorge Luis Borges con Antonio Carrizo (México: Fondo de cultura económica, 1986), 27-28. 
una primera edición por Edmundo Rivero. Este último en su libro de memorias afirma:

«Misteriosamente, sus letras me suenan tan auténticas como las de Contursi, aunque use muy distintas palabras. Es seguro de que Borges "ha visto" más cosas que muchos otros letristas salidores y nocheros, tal vez porque supo escuchar o porque sabía cuáles eran las preguntas, cosa que suelen olvidar los que siempre buscan respuestas». ${ }^{187}$

El disco se llamará El tango e incluirá parte de las milongas de Borges. Se agregaron a la lista otros tres: «El Tango», "Oda íntima a Buenos Aires» y «Alguien le dice al tango», este último incluido en la primera edición de Para las seis cuerdas, pero excluido en la segunda. Cerrará el disco la suite que Piazzolla compuso a partir del relato borgiano El hombre de la esquina rosada.

La relación entre Borges y Piazzola no fue un camino de rosas. E primero, además de no ser un entendido en música ni un gran melómano, volvía siempre a los orígenes del tango y buscaba aquellas primeras aventuras de cuchilleros, toda aquella épica que se perdió durante su infancia y que sólo conocía "de oídas". Historias que se narraban con el simple acompañamiento de una guitarra y que encajaban más en la visión de Carriego que en la del bandoneonista y compositor. Por otro lado, Astor Piazzola representa la renovación del tango, lo que se conoció como Tango nuevo o Vanguardia.

En los textos de las milongas Borges pretende presentar un momento concreto en la vida de Buenos Aires y los personajes y circunstancias que lo protagonizaron; por ello, hay ciertas palabras y temas que van a ser recurrentes.

Lo primero que nos queda claro al leer y/o escuchar las milongas de Borges es el lugar y el tiempo al que nos quiere llevar: Buenos Aires a finales del s. XIX. Es más, en dos de sus textos, «Milonga a Don Nicanor Paredes» y «Milonga de Albornoz», hace una referencia explícita a este tiempo: "el

187 Edmundo Rivero, Una luz de almacén (El lunfardo y yo) (Buenos Aires: Emecé editores, 1982), 107. 
ochocientos noventa". En cuanto a los espacios, no hay más que repasar la cantidad de topónimos que emplea para referirse a lugares — barrios, zonasconcretos de la ciudad de Buenos Aires.

El ambiente que Borges pretende reflejar es el de los compadritos, los guapos a quienes considera los "valientes" que lucharon cuchillo en mano y para quienes el código de honor era la base de su existencia. Por ello, dedica varias de las milongas a personajes reales que pudo conocer directa o indirectamente y que protagonizaban lo que él mismo llamó "secta del cuchillo y del coraje" y que es objeto de nuestro análisis en este trabajo puesto que constituye un código de honor solo válido para hombres. Estos personajes son los hermanos Iberra, Jacinto Chiclana, Nicolás Paredes, Alejo Albornoz, Manuel Flores y Servando Cardoso, protagonistas de seis de las once milongas que componen este libro.

Otra de las milongas, «¿Dónde se habrán ido?», refleja la nostalgia de Borges por aquellos tiempos dirigiéndose directamente a los "valientes":

\footnotetext{
«¿Dónde está la valerosa

chusma que pisó esta tierra, la que doblar no pudieron perra vida y muerte perra, los que en el duro arrabal vivieron como en la guerra, los Muraña por el Norte y por el Sur los Iberra?». ${ }^{188}$
}

Esta valentía que para el escritor define a estos hombres será el motor de esa secta de la que nos hablaba. Borges admiró todas aquellas historias que conoció por vecinos como Evaristo Carriego u otros como Nicolás Paredes. Estos sí fueron protagonistas de las anécdotas arrabaleras que él no pudo vivir en primera persona. Quizá le gustaría haber sido como aquellos

188 Jorge Luis Borges, «¿Dónde habrán ido?», Para las seis cuerdas. Obras Completas I (Barcelona: RBA Coleccionables, Instituto Cervantes, 2005), 957. 
antepasados que habían luchado en las guerras argentinas y no sentirse un hombre cobarde, como en numerosas ocasiones ha manifestado.

El poema «¿Dónde se habrán ido?» está dedicado a los valientes y en él Borges se pregunta dónde estarán, a dónde habrán ido y él mismo se responde: en la memoria...:

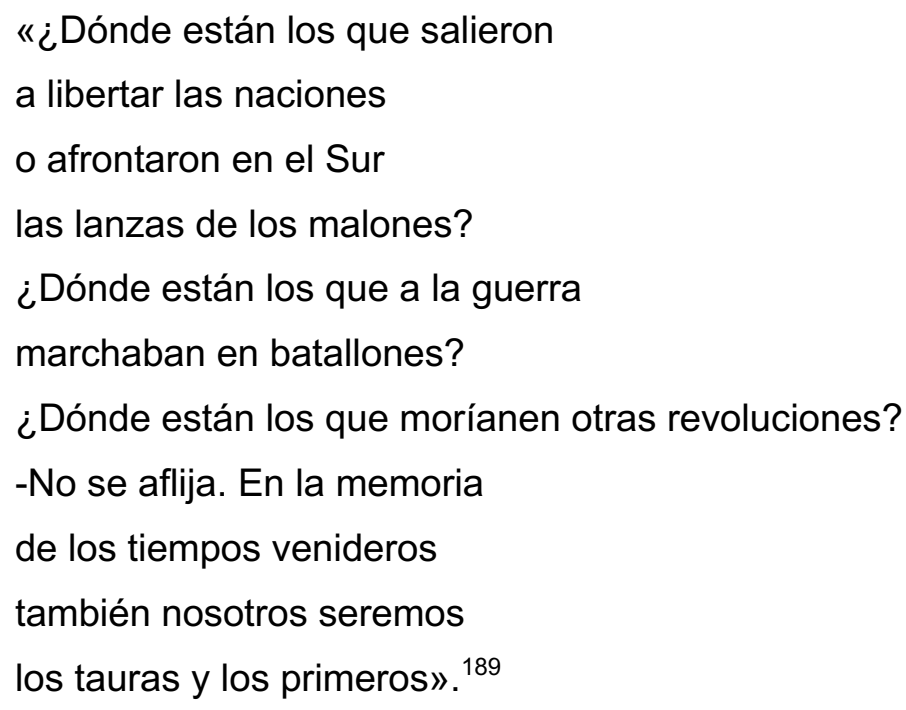

El poema «El títere» está dedicado a un compadrito y en él Borges nos describe perfectamente su carácter y su vestimenta. No nos hacen falta más de cuatro versos:
«Atildado en el vestir,
medio mandón en el trato;
negro el chambergo y la ropa,
negro el charol del zapato». ${ }^{190}$

Por último, uno de los poemas más representativos de esa nostalgia de Borges por las valientes hazañas épicas que no pudo vivir durante su infancia

189 Jorge Luis Borges, Para las seis cuerdas. Obras Completas I (Barcelona: RBA Coleccionables, Instituto Cervantes, 2005), 957.

190 Ibidem, 964. 
y juventud es «Un cuchillo en el norte». Se podría decir que el cuchillo es una de las metonimias borgianas más recurrentes y con ella nos habla del coraje, la valentía y la virilidad. Señalamos ya este elemento como nexo de unión entre el gaucho y los tipos masculinos urbanos al describir la coreografía de Santiago Ayala y es para nosotros un símbolo claro de masculinidad. El cuchillo, puñal o facón es un instrumento de defensa, pero también es utilizado para dar muestras de autoridad.

En el Prólogo de Para las seis cuerdas, acerca del acompañamiento musical que él imagina para sus poemas nos dice Borges:

«En el modesto caso de mis milongas, el lector debe suplir la música ausente por la imagen de un hombre que canturrea, en el umbral de su zaguán o en un almacén, acompañándose con la guitarra. La mano se demora en las cuerdas y las palabras cuentan menos que los acordes». ${ }^{191}$

Como vemos, Borges pensaba en algo sencillo, un canturreo y un escaso acompañamiento de guitarra. La guitarra, ya lo hemos dicho anteriormente es, junto al cuchillo, un elemento que el hombre urbano del XIX de alguna manera hereda del gaucho.

Quizá de todos los temas que musicó Piazzolla el que más pueda responder a las expectativas de Borges —estas serían representar a los protagonistas del arrabal-sea el primero, «Jacinto Chiclana», por lo sencillo de su melodía y de su acompañamiento.

El poema titulado «El tango» fue publicado en 1958 en una revista y luego recogido en el libro El otro, el mismo (1964). En él encontramos alusiones a los Iberra, al Ñato, personajes que veíamos como protagonistas de las milongas de Para las seis cuerdas. Este texto contiene toda la temática que desarrollará años después en este libro: la secta del cuchillo y el coraje, la nostalgia de valientes, el puñal y, lo que es más importante, lo contextualiza alrededor del tango. En la primera parte del texto se preguntará dónde estarán esos personajes de hazañas tan valerosas, y a partir de la décima estrofa se responde él mismo y dice que perdurarán en la música, en concreto, en el

191 Ibidem. 
tango. Por ello, éste es un texto fundamental a la hora de analizar el pensamiento de Borges en lo que a música y tango se refiere. Para Borges la valentía es un elemento inherente al tango, aunque él lo propone de una manera inversa a la nuestra. Él ve el tango como un género que conserva la valentía perdida por los hombres y nosotros vemos esa valentía como uno de los elementos que han conseguido preservar el tango.

En «Alguien le dice al tango» encontramos un texto en octosílabos compuesto por populares cuartetas. Estas letras están dedicadas al tango y, al igual que sucedía en el tema anterior, Borges proclama el tango como guardián de las historias orilleras; volvemos a leer términos como cuchillo, valiente, recuerdo y olvido.

«Oda íntima a Buenos Aires», en opinión de Astor Piazzolla,

«es quizá la más audaz de todos los temas cantados. A pesar de esto, la línea melódica es simple pues comienza en forma cromática ascendente y termina en forma cromática descendente». ${ }^{192}$

El texto escrito por Borges está dedicado a la creación de la ciudad de Buenos Aires y a quienes la construyeron, como deja claro el empleo de la anáfora "la hicieron" seguida de diferentes y variados motivos y maneras en las que fue fundada.

La suite "El hombre de la esquina rosada" fue compuesta en marzo de 1960 en Nueva York y posteriormente se incluyó en el disco El tango. Según cuenta Piazzolla, fue una idea de la coreógrafa Ana Itelman, quien adaptó frases del cuento originario de Borges a la partitura que Piazzolla había compuesto para recitante, canto y doce instrumentos. El relato «El hombre de la esquina rosada» ${ }^{193}$ fue publicado por primera vez con el nombre de «Leyenda policial» en la revista Martín Fierro del 26 de febrero de 1927. Una segunda versión integró el volumen de El idioma de los argentinos en 1928 con el nombre de «Hombres pelearon» y una tercera se publicó como

192 Ibidem.

193 Jorge Luis Borges, «El hombre de la esquina rosada», Historia Universal de la Infamia. Obras Completas I (Barcelona: RBA Coleccionables, Instituto Cervantes, 2005), 331. 
Hombres de las orillas en el diario Crítica del 16 de septiembre de 1933. La versión final con su nombre definitivo integró el volumen Historia universal de la infamia, que se publicó en 1935.

Este cuento nos acerca una historia contada por un narrador a un supuesto auditor, Borges. Rosendo Juárez es un cuchillero que una noche, en un lugar en el barrio de Santa Rita, cerca del arroyo Maldonado, es retado por Francisco Real, el Corralero. Juárez se niega a pelear, por lo que la prostituta que lo acompaña, la Lujanera, avergonzada por la cobardía de su hombre, lo deja para irse con Real. Poco después la prostituta entra cargando con el cadáver del compadrito, anunciando que desconoce quién lo ha matado pero que no era Rosendo Juárez. Finalmente, el narrador de la historia nos sugiere su propia culpabilidad. El vocabulario empleado es muy popular y en ocasiones tosco y rústico, al puro estilo orillero.

El origen del tango es, en nuestra opinión, el aspecto más interesante del que nos habla Borges. Entiende el tango como representación de la historia de una parte de Buenos Aires: el arrabal, los malos, los guapos, la muerte, el cuchillo y el coraje. Es especialmente esclarecedor en este sentido el capítulo «Historia del tango», incluido en su libro Evaristo Carriego ${ }^{194}$ escrito en 1930 pero revisado para su publicación en los años 70. Una de las afirmaciones que podría servirnos de punto de partida para entender lo que el escritor nos quiere decir es la siguiente:

«Tal vez la misión del tango sea ésa: dar a los argentinos la certidumbre de haber sido valientes, de haber cumplido ya con las exigencias del valor y el honor». ${ }^{195}$

Para él, el tango es porteño; y más concretamente, tiene su origen en los lupanares. Justifica esta afirmación dando la siguiente argumentación:

«El instrumental primitivo de las orquestas —piano, flauta, violín, después bandoneón-confirma, por el costo, ese testimonio; es una prueba de que el 2008)

194 Jorge Luis Borges, Evaristo Carriego (Madrid: Biblioteca Borges. Alianza Editorial, 195 Ibidem, 137. 
tango no surgió en las orillas, que se bastaron siempre, nadie lo ignora, con las seis cuerdas de guitarra. Otras confirmaciones no faltan: la lascivia de las figuras, la connotación evidente de ciertos títulos (“El choclo", "El fierrazo"), la circunstancia que de chico pude observar en Palermo y años después en la Chacarita y en Boedo, de que en las esquinas lo bailaran parejas de hombres, porque las mujeres del pueblo no querían participar en un baile de perdularias.» ${ }^{196}$.

Ya en el año 1927 Borges escribe en un artículo de la revista Martín Fierro un texto titulado "Ascendencias del tango» ${ }^{197}$ en el que resume la historia del tango como él la entiende: el origen porteño, la influencia del compadrito, y todas las demás ideas que estamos desarrollando en este capítulo.

En su libro El idioma de los argentinos -libro escrito unos años antes de Evaristo Carriego- Borges pone en cuestión la idea de Vicente Rossi de que el tango procede de la milonga montevideana y de la habanera. Ya nos referimos en el Estado de la Cuestión a las opiniones de los investigadores al respecto. La opinión de Borges en relación al lugar en el que se origina el tango es clara: «El tango es porteño. El pueblo porteño se reconoce en él, plenamente, no así el montevideano, siempre nostalgioso de gauchos». ${ }^{198}$

Como bien apunta Horacio Salas en su Biografía ${ }^{199}$, para Borges el tango no forma parte de la historia, sino de la leyenda de la ciudad de Buenos Aires. Sin embargo, lo que él denomina "secta del cuchillo y del coraje" no es sólo una recopilación de leyendas, sino que es fruto de un tiempo y de un lugar; existieron de verdad, aunque Borges no pudiera vivirlas y ello le permitiera idealizarlas hasta el límite de crear, a través de estas historias, su propia leyenda personal. Lo que no se puede afirmar, y de ello también hablamos al tratar lo nuevos paradigmas que rigen la investigación de este género, es que el tango se bailara únicamente en los lupanares o que hubiera

196 Ibidem, 132.

197 Jorge Luis Borges, «Ascendencias del tango», Martín Fierro, 37 (1927): 296.

198 Jorge Luis Borges. El idioma de los argentinos (Madrid: Biblioteca Borges. Alianza Editorial, 2008), 101.

199 Horacio Salas. Borges. Una biografía (Buenos Aires: Editorial Planeta, Biografías del Sur), 266. 
sido prohibido por las autoridades. Sin embargo, la relevancia de todo este trabajo de Borges que acabamos de presentar reside en la intención del escritor de retratar el carácter argentino, y no tanto de representar la realidad tal y como sucedió.

Uno de los pilares de la vida y la obra de Jorge Luis Borges es el recuerdo y la nostalgia del pasado, de lo vivido por sus ancestros en un momento histórico muy diferente al que él mismo vivió. En nuestra opinión, es esta nostalgia, junto con el hecho de haber vivido de alguna manera de espaldas a lo que sucedía en las orillas, lo que da lugar a esta visión que Borges nos plantea acerca del tango, su origen y su naturaleza.

En cuanto al carácter del tango originario, Borges defiende que era alegre y valiente, criollo, valeroso y compadre; esta definición se opondría completamente a la famosa frase de Enrique Santos Discépolo "el tango es un pensamiento triste que se baila". A este respecto Borges nos dice:

«Lo de triste es lo que me parece más raro. Cuando yo digo que el tango es alegre y que suele ser valeroso y compadre (El apache argentino, por ejemplo), lo cual no se aviene con la tristeza, con esto no quiero decir que los compadres no sentirían tristeza: quiero decir que se hubieran avergonzado de confesarlo; quiero decir que ningún compadre se hubiera quejado de que una mujer no lo quiere, por ejemplo, porque eso hubiera pasado por una mariconería» ${ }^{200}$.

Todo este pensamiento de Borges acerca del tango en sus primeros años nos lleva de nuevo a lo que hemos denominado "relato clásico": el prostíbulo, los compadritos y la masculinidad. En los textos de Borges - no sólo en los que tratan el tema del tango- están presentes como protagonistas los tipos masculinos que se analizan en nuestro trabajo porque, como nosotros, también él los considera creadores del género, al menos desde el punto de vista de su imagen y teniendo en cuenta que a menudo este género se creó partiendo de una o varias leyendas populares. No hablamos de si un

${ }^{200}$ Fernando Sorrentino, Siete conversaciones con Jorge Luis Borges (Buenos Aires: Editorial el Ateneo, 1999), 207. 
compadrito fue el primer hombre que bailó un tango, ni si lo hizo en un prostíbulo. Pero el carácter, el caminar y la actitud de este tipo de hombres tuvo tal relevancia social que aún lo vemos reflejado en algunos bailarines. Lo que exponemos en este trabajo es que el compadrito - como personaje que engloba los rasgos de quienes le precedieron- es un modelo para bailarines aún en la actualidad destacando como su principal rasgo la masculinización de sus gestos, su caminar y su posición corporal. Si bien, matizaremos más adelante en qué ámbitos estos rasgos se presentan de modo más evidente.

De todos los autores consultados Carriego, del Mazo y Borges parecen presentarse como los más interesados en situar el tango en los suburbios y en destacar el compadrito como su protagonista.

Hablemos ahora de dos autores que, además de hablar de tango, integran en su particular representación de la sociedad anterior al establecimiento del estado moderno, la figura del gaucho. Recordemos que es el punto de partida de El Chúcaro y que nosotros lo vemos como la figura en la que por primera vez se reúnen todos los rasgos y muestras de hombría que se exigirán en el hombre moderno posteriormente. Estos autores son Ricardo Güiraldes y Fernán Silva Valdés. El primero, además, fue considerado un gran bailarín. Comencemos hablando de él y de su obra.

La relación de este importante escritor argentino con el tango es especialmente interesante por el hecho de que, como ya hemos apuntado, lo vivió en primera persona: aprendió a bailarlo en conventillos y burdeles del barrio de La Boca y se lo llevó con sus amigos y con él a París. Pero Ricardo Güiraldes también se interesó por el folclore, tocaba la guitarra y escribió una de las novelas — junto con Martín Fierro- más aclamadas de la literatura argentina entendida como símbolo de la identidad nacional dentro de esa corriente nacionalista heredera de la celebración del Centenario. Cuando el argentino recupera el gaucho, la pampa y los payadores y se propone alzarlos como símbolo del país, Güiraldes viaja a París. Allí baila el tango y lo presenta ante la atenta aristocracia como un símbolo más de su país. Según Victoria Ocampo él fue — junto a amigos como Vicente Madero- el que llevó el tango a París y uno de los principales responsables de que saliera del Río de la 
Plata y conquistara el resto del mundo. Allí escribió su poema «Tango», recogido en su libro El cencerro de cristal201.

«Tango severo y triste.

Tango de amenaza.

Tango, en que cada nota cae pesada y como a despecho, bajo la mano más bien destinada]

para abrazar un cabo de cuchillo.

Tango trágico, cuya melodía juega con un tema de pelea.

Ritmo lento, armonía complicada de contratiempos hostiles.

Baile que pone vértigos de exaltación viril en los ánimos que enturbia la bebida Creador de siluetas, que se deslizan mudas, bajo la acción hipnótica de un ensueño sangriento.]

Chambergos torcidos sobre muecas guasas.

Amor absorbente de tirano, celoso de su voluntad dominadora.

Hembras entregadas, en sumisiones de bestia obediente.

Risa complicada de estupro.

Aliento de prostíbulo. Ambiente que hiede a china guaranga y a macho en sudor de lucha.]

Presentimiento de un repentino estallar de gritos y amenazas, que concluirán por sordo

quejido, en un chorrear de sangre humeante, como última protesta de ira inútil. Mancha roja, que se coagula en negro.

Tango fatal, soberbio y bruto.

Notas arrastradas, perezosamente, en un teclado gangoso.

Tango severo y triste.

Tango de amenaza.

Baile de amor y muerte».

Este poema refleja todos los estereotipos del tango de los primeros años: el prostíbulo, la pelea, el cuchillo, amor y muerte, hembra entregada y -lo que nos interesa más ahora- la virilidad. Muestra el tango como un ritual con alto grado de animalidad, más como un duelo de machos dominando sus hembras que como una danza que, según el nuevo relato, se bailaba también

201 Ricardo Güiraldes, El cencerro de cristal, acceso el 25 de enero de 2021, http://www.cervantesvirtual.com/obra-visor/el-cencerro-de-cristal--0/html/ff2a4102-82b111df-acc7-002185ce6064_3.html 
en ambientes aristocráticos. Ricardo Güiraldes era lo que se conocía como un niño bien, con estudios - aunque no terminados - y con una posición familiar que le permitió viajar a París y a otros lugares en los que se relacionaría con intelectuales y artistas. Pero lo que escribió allí en 1911 quizá hablaba del tango tal y como lo entendieron cuando llegó a Europa, lo que era antes de salir de Buenos Aires. Quizá lo que triunfó en París fue efectivamente lo exótico de un baile irrepetible o la imagen que las élites quisieron llevar allí, pero eso ya desborda de nuestro ámbito de estudio. Lo que sí es cierto es que Ricardo Güiraldes nunca abandonó el tango y quizá el cambio que sufre el tango en Europa le hizo añorar la Argentina decimonónica y por eso regresó de París por razones que quedan muy claras en una carta que escribió a un amigo:

«Mirá, che, ha sido en París donde comprendí una noche que me vi solito mi alma, que uno debe ser un árbol de la tierra en que nació: espinillo arisco o tala pobre. Acababa de dar una vuelta completa al mundo y esa noche de nieve me corrió por lo despiadada, y lo que era más que la escarcha nuestra, porque era nieve extranjera. Me sentí huérfano, guacho y ajeno a mi voz, a mi sobre y a mi raza. Lié mis petates y ¡hasta la vuelta! Le dije, che. Cuando bajé del barco, tomé un pingo y me entré, como cuando era cachorro, hasta el corazón de la pampa». ${ }^{202}$

Volvió a sus orígenes y a los orígenes del Río de la Plata. Vivió en La Porteña, hacienda familiar donde pasó parte de su vida. Se centró en el campo, en la vida gaucha de la Pampa y en 1926 publica definitivamente Don Segundo Sombra. Los primeros capítulos de esta novela los escribió en otro viaje a Europa que realizó una vez finalizada la Gran Guerra. Pretende en este texto recuperar los valores morales de la vida del campo encarnados en la figura del gaucho que, como defendemos en este trabajo y de acuerdo con la propuesta de El Chúcaro, representa el punto de partida del linaje masculino

\footnotetext{
202 Juan Manuel Peña, «Ricardo Güiraldes, el gaucho que bailó el tango», La Nación (2009), acceso el 25 de enero de 2021, https://www.lanacion.com.ar/economia/campo/ricardo-guiraldes-el-gaucho-que-bailo-tangonid1119447/.
} 
que será protagonista y creador —estéticamente hablando- del tango en los últimos años del siglo XIX.

A su muerte, que tendrá lugar sólo un año más tarde, Borges escribió:

«Nadie podrá olvidar su cortesía;

era la no buscada, la primera

forma de su bondad, la verdadera

cifra de un alma clara como el día

No he de olvidar tampoco la bizarra

serenidad, el fino rostro fuerte,

las luces de la gloria y de la muerte,

la mano interrogando la guitarra.

Como en el puro sueño de un espejo (tú eres la realidad, yo su reflejo)

te veo conversando con nosotros

en Quintana. Ahí estás, mágico y muerto

Tuyo, Ricardo, ahora es el abierto

campo de ayer, el alba de los potros.» ${ }^{203}$

Ulyses Petit de Murat le escribe un tango titulado «Bailate un tango Ricardo» al que pone música Juan D’Arienzo:

«Le saco orilla a mi vida para arrimarla a tu muerte.

Total la vida es la suerte que se da por el retardo

medio haragán de la muerte y yo estoy ya que me ardo

por gritarte fuerte, fuerte ¡bailate un tango, Ricardo!

(Ricardo Güiraldes baila y el ángel del recuerdo lo acompaña/se manda una medialuna y un intenso puente macho rubricando Buenos Aires de arrabal con Pampa y Tango).

¡Bailate un tango, Ricardo! Míralo a quien te lo grita

pues no es ninguna pavada, ese muchacho es el bardo

el de La Crencha Engrasada. De la Púa ahora te invita;

¡bailate un tango, Ricardo!

203 Jorge Luis Borges, «Ricardo Güiraldes», El elogio de la sombra en Obras Completas I (Barcelona: RBA Coleccionables, Instituto Cervantes, 2005), 988. 
(Ricardo Güiraldes baila saliéndose de la vida...

al bailar lleva dormida como antaño a las mujeres

a la muerte que murmura perdida en el entresueño,

bailate un tango, Ricardo)»204

Encontramos también en este poema de Petit de Murat una de esas referencias a la masculinidad que casi se nos hace ya imprescindible en los textos de la época y en parte del tango: "un intenso puente macho". Suele escribirse que el tango se defiende como "macho" en los años 60 del siglo XX, pero a estas alturas tenemos ya claro que, desde mucho antes, la historia del tango que fue empleado para permitir a los hombres de la época dar cuenta de su hombría, había comenzado a narrarse.

En cuanto a Güiraldes, quizás su mayor homenaje a ese ideal de masculinidad será su novela Don Segundo Sombra, donde encontramos un verdadero tratado de cómo defenderse en la vida del campo, pero también de cómo hacerse hombre. Todo ello encarnado en la figura del gaucho. Algunas de estas referencias son: "Ya has corrido mundo y te has hecho hombre, mejor que hombre, gaucho», 205 "El hombre que se mama ha de ser güen(sic) hombre». ${ }^{206}$ En muchas páginas nos encontramos con nuestro habitual vocabulario masculino: compadreo, compadradas: fanfarronadas.

También se jacta el protagonista de haber cumplido con las pruebas de su patrón y dice:

"iQué voluntad de dominio no tendrá el hombre para que, por un rato de gozarla, emplee largas horas de perseverante empuje!». ${ }^{207}$

El tipo de pruebas a las que somete Don Segundo Sombra al protagonista para que aprenda a vivir y a trabajar en el campo son interpretadas como alcanzar la hombría. Es posible que el gaucho sea la

204 Ulyses Petit de Murat, «Bailate un tango, Ricardo», Todo tango. Letras, acceso el 20 de enero de 2020, https://www.todotango.com/musica/tema/2157/Bailate-un-tangoRicardo/

205 Ricardo Güiraldes, Don Segundo Sombra (Madrid: Editorial Cátedra, 1998), 224.

206 Ibidem, 245.

207 Ibidem, 275. 
representación más completa de la masculinidad. En él convergen todos los rasgos que se le aplican a un hombre digno de serlo: valentía, fuerza, tesón y voluntad de dominio. Veremos más adelante que el escritor Leopoldo Lugones hablaba en los mismos términos.

Otro rasgo presente en la novela y que define a un hombre como valiente es la capacidad de "compadrear". Veamos un ejemplo donde dos personajes se enzarzan en un duelo a cuchillo. Las espuelas, el poncho y el facón protagonizan la escena pero lo que de verdad destaca es el descaro y la despreocupación por el peligro:

«El forastero se acercó y, confiado, como quien juega con un chico, tiró a su contrario una cachetada con los flecos del poncho. Antenor hizo un imperceptible movimiento y el poncho pasó sin tocarlo. El quite fue de una precisión admirable, ni un dedo más ni un dedo menos de lo necesario. Creo que todos debimos pensar a un tiempo; ipobre paisano viejo, su compadrada le iba a salir amarga!». ${ }^{208}$

Al terminar la pelea uno de los personajes hace la siguiente reflexión:

«Nos mata el orgullo, amigo. Cuando un hombre nos insulta, lo mejor que podríamos hacer es llamarnos Juan. Pero tenemos nuestro orgullo, que nos hace querer hablar mah'alto(sic), y una palabra trai(sic) otra y al fin no queda más que el cuchillo». ${ }^{209}$

Don Segundo Sombra es la historia de un aprendizaje, de un camino que recorre un niño para convertirse en gaucho, pero también para ser hombre. O, mejor dicho, paso previo a ser gaucho era hacerse un hombre. Por eso creemos que en esa figura tan mítica pero tan real encontramos el ser masculino perfecto, el que reúne todas las cualidades de las que hemos ido hablando y que está directamente relacionado con la ley del fuerte:

«Por su bien, el resero tiene la vida demasiado cerca para poder perderse en cavilaciones de índole acobardadora. La necesidad de luchar continuamente, no le da tiempo para atardarse en derrotas; o sigue, o afloja del todo, cuando

\footnotetext{
208 Ibidem, 280.

209 Ibidem, 282.
} 
ya ni un poco de poder le queda para encarar la vida. Dejarse ablandar por una pasajera amargura, lo expone a tomar el gran trago de todo cimarrón que se acoquina: la muerte. Una medida grande de fe le es necesaria, en cada momento, y tiene que sacarla de adentro, cueste lo que cueste, porque la pampa es un callejón sin salida para el flojo. Ley del fuerte es quedarse con la suya o irse definitivamente». ${ }^{210}$

La correcta moralidad es un rasgo también imprescindible en el hombre y esto está presente en Don Segundo Sombra:

«El gaucho dentro de sus medios limitados, es un tipo de hombre completo. Tiene sus principios morales y esto lo prueba diciendo como elogio entre elogios; 'es un gaucho de ley'». ${ }^{211}$

Estos valores morales los conservará el guapo, así como también el compadre y en cierto modo el compadrito, según nosotros entendemos que fueron evolucionando estos tipos o modelos masculinos. Al hablar de ellos en los preliminares de este capítulo hemos visto cómo los principios morales supondrán un camino de degradación cuyo punto de partida sería, efectivamente, el gaucho.

Además de Güiraldes, también el poeta y dramaturgo uruguayo Fernán Silva Valdés se interesó por la figura del gaucho y, de hecho, se le reconoce como representante de la corriente literaria denominada nativismo, que pretendía una vuelta a las referencias nacionales como el gaucho y el campo. Silva Valdés fue, además, compositor de tangos.

En un ejemplar de la revista Cartel de febrero de 1930 encontramos publicado el siguiente poema de su autoría. Su título es «Croquis para un tango»:

«En la cancha del baile

se varea el viento de los bandoneones:

viento música.

que peina las cabezas de los bailarines.

210 Ibidem, 285.

211 Véase la nota al pie 4 en Ricardo Güiraldes, Don Segundo Sombra (Madrid: Editorial Cátedra, 1998), 297. 
Se abrochan las parejas.

Cada pareja es una cosa aislada,

ente de dos piezas con un alma/sola;

un ente de dos piezas machimbradas,

abrigadas, mutuamente

para que no les pase el frío de la luz.

Las virutas de la música

se desenrollan en el aire de la sala

como los lazos ganchos

y también como éstos se ciñen a los cuerpos.

De la derecha a la izquierda,

hacia adelante y lentos van los bailarines,

rayando "medias lunas", "pasetes" y "corridas"

y los ritmos compadres del tango milongón

corporizados en las piernas son música en acción.

De pronto se aploman

en una actitud de echar raíces

el hombre y la mujer;

y parecen un árbol,

un árbol de dos troncos que se han juntado en uno:

los brazos son las ramas;

Los trapos coloreados de la bella son las flores

rocío de brillantes mencionan intemperies;

y para que sea más árbol este tango:

un sonoro taconeo

le hunde sus raíces malevas en la alfombra».

En El agua del tiempo encontramos un poema titulado «El Puñal» en el que el autor relaciona esta arma con el gaucho, la guitarra, el poncho y el mate. Recordamos que en el cuadro coreográfico de Santiago Ayala el facón es un elemento importante puesto que es lo único que el compadrito conserva de su antecesor, el gaucho. Nosotros vemos en este elemento una enorme cantidad de significado. El puñal es valor, es coraje, es libertad, es comida, es honra y es, fundamentalmente, gaucho. En la ciudad este elemento sigue su camino junto al guapo, al compadrito y al hombre en general, pero, al igual que decíamos al hablar de que cada vez son menos las normas morales que 
rigen la vida de los hombres, el puñal también va perdiendo sentido, hasta que, con la modernidad, desaparece.

En el mismo libro encontramos el poema «El tango»:

«Tango milongón,

corazón del arrabal;

Eres como una viruta musical,

Como una viruta de bandoneón.

Como una queja que se estira

produciendo escozor y placer;

eres una música que se respira,

que tiene forma de curva y que huele a mujer.

Música primitiva pero civilizada;

que calienta la sangre y emborracha a las gentes;

una música rara

que se acompaña con el cuerpo,

y con los labios, y con los dientes,

como si mascara.

Pegajosa como la miel, y que fatiga sin fatigar;

resbala por los nervios como por un riel,

y se baila con los cinco sentidos

Puestos en el bailar.

Tango:

por entre la cadencia de tu música queda

yo palpo la dureza viva del arrabal,

como por entre una de seda

la hoja de un puñal.

Tango milongón,

tango compadrón,

que a pesar de bailarse con todas las ganas

se baila como sin ganas,

como en carriles de lentitud;

eres un estado del alma de la multitud». ${ }^{212}$

${ }^{212}$ Fernán Silva Valdés, Agua del tiempo (Buenos Aires: Editorial Claridad, 1925), $27-$ 28. 
¿A qué multitud se refiere? A quienes lo escuchan, a quienes lo bailan, a la sociedad rioplatense. Si tenemos en cuenta la preocupación por lo autóctono de este dramaturgo, fácilmente podemos concluir que el tango, al menos para él, lo es.

Escribió también algunos tangos: "Adiós Argentina», "Agua florida», "Canción del árbol del olvido», "Clavel del aire», «Dicen en todo el pago», «En blanco y negro», «Margarita punzó», «Quejas», «Yo me llamo Juan te quiero». En el primero nos habla de un gaucho varón y altanero. En Quejas se muestra como un hombre abandonado y en su tango "Yo me llamo Juan te quiero» encontramos, de nuevo, el varón, la china, el puñal y el facón.

Hasta ahora hemos hablado de intelectuales y literatos que de alguna manera nos hablaron del tango, de su ambiente, pero también del gaucho y el campo. A continuación, nos ocuparemos de un escritor que introduce un concepto que ninguno de los anteriores había contemplado, por muchos motivos. Se trata de Ernesto Sábato y el hibridaje. Cuando Sábato hablaba del tango no lo hacía, como Borges, refiriéndose a la milonga, sino al producto del arrabal porteño. Destacaba lo nostálgico y melancólico de este género relacionándolo con la tristeza de los inmigrantes - mayoritariamente masculinos- o el rencor de los nativos. Veamos detenidamente su discurso.

En 1963 escribe Tango. Discusión y clave ${ }^{213}$, donde habla del género y nos presenta su visión acerca, principalmente, de su carácter derivado del momento político y social en el que surge. Además, nos presenta una recopilación de opiniones sobre el tango realizada bajo su supervisión por Tabaré Di Paula y Noemí Lagos. Como veremos más adelante este trabajo aparece incluido en el libro El tango, de Horacio Salas.

Sobre el origen del tango Sábato nos cuenta que es un baile híbrido creado por gente híbrida. Cree que es una mezcla de habanera, milonga y en un alto porcentaje de música italiana. Lo ve en sus inicios como representación del país incipiente que era Argentina que se caracterizaba por «el desajuste, la nostalgia, la tristeza, la frustración, la dramaticidad, el

${ }^{213}$ Ernesto Sábato, Tango. Discusión y clave (Buenos aires: Editorial Losada, 1963). 
descontento, el rencor y la problematicidad». ${ }^{214}$ En la siguiente cita lo explica más detalladamente:

«Pocos países en el mundo debe de haber en que el sentimiento de nostalgia sea tan reiterado: en los primeros españoles, porque añoraban su patria, lejana; luego en los indios, porque añoraban su libertad perdida y su propio sentido de la existencia; más tarde en los gauchos desplazados por la civilización gringa, exilados en su propia tierra, melancólicamente rememorando la edad de oro de su salvaje independencia; en los viejos patriarcas criollos, porque sentían que aquel hermoso tiempo de la generosidad y de la cortesía se convertía en el materialismo y mezquino territorio del arribismo y de la mentira. $Y$ a esa base híbrida de sucesos y sensaciones se suma un último hecho significativo: "los inmigrantes, porque extrañaban su viejo terruño europeo, sus costumbres milenarias, sus navidades de nieve junto al fuego, las viejas leyendas de sus lares». ${ }^{215}$

Entre las múltiples citas recogidas para la segunda parte de Tango. Discusión y clave, destacan algunas que nos hablan del origen del tango. Por ejemplo, nos remite a la cita de Tallón que dice «... el tango bailado en nuestros días por las familias, no es un hijo del traficante ni del prostíbulo, sino del pueblo proletario...» ${ }^{216}$. Recordemos que Tallón alababa la masculinidad del tango de los comienzos en contraposición con el giro "amariconado" que había adquirido con personajes como el compadrito ${ }^{217}$.

Además de este ensayo Sábato entró de lleno en el género tango con la composición de «Alejandra», tango al que Aníbal Troilo pondrá música y que se basa en uno de los personajes de Sobre héroes y tumbas, novela de 1961. Esta composición será en 1966 la aportación de Ernesto Sábato al gran proyecto discográfico de Ben Molar 14 con el tango, donde un grupo de intelectuales de la época aportaban sus tangos con el objetivo de ayudar al género rioplatense que durante esos años estaba en decadencia.

\footnotetext{
214 Ibidem, 19.

${ }^{215}$ Ernesto Sábato, «La tristeza de los argentinos», Gaceta Literaria 12, Año II (1958).

${ }^{216}$ Ernesto Sábato, Tango, discusión y clave (Buenos Aires: Editorial Losada, 1963),

${ }^{217}$ Véase nota al pie 170 de este trabajo.
} 33. 
Unos años antes, en 1963, Piazzolla publica su LP Tango contemporáneo en el que incluye una pista titulada «Introducción a Héroes y tumbas», basada en la obra de Sábato.

Es quizás en su última aportación al tango donde Sábato refleja lo que significa para él, lo que representa. Se trata del tango «Al Buenos Aires que se fue», incluido en otro proyecto de Ben Molar del año 1975 para el disco Los 14 con Julio de Caro. En este texto el autor se lamenta de la pérdida del alma del suburbio, ese lugar legendario que sin embargo existió.

Lo que realmente nos interesa es lo que nos cuenta Sábato en el capítulo titulado «Bandoneón» en Tango. Discusión y Clave. Afirma tajantemente en el tercer párrafo que el compadre es «el rey de este submundo» ${ }^{218}$. De nuevo, como lo hicieron Borges, Carriego y del Mazo, Ernesto Sábato sitúa en el centro al compadrito, del que dice que es rencoroso y corajudo, jactancioso y macho ${ }^{219}$.

Decíamos que este autor nos aportaba un concepto nuevo que denomina hibridaje 220 , puesto que en los anteriores apenas encontrábamos alusiones al proceso inmigratorio y más bien miraban hacia atrás, hacia el pasado del gauchaje como representación de lo nacional. Pues bien, parece que este camino también nos conduce al protagonista macho, como decíamos aludiendo a las propias palabras de Sábato líneas arriba.

En este capítulo de análisis de las fuentes literarias nos queda sólo hablar de dos de los escritores más críticos con el tango, especialmente el primero de ellos. Hablamos de Leopoldo Lugones y Carlos Ibarguren.

Leopoldo Lugones fue uno de los poetas más importantes de la literatura argentina, siendo enmarcada su obra dentro del movimiento modernista. Pero Lugones fue también una figura relevante por cuestiones políticas, que condicionarían toda su vida. Desde un primigenio socialismo la

18.

${ }^{218}$ Ernesto Sábato, Tango, discusión y clave (Buenos Aires: Editorial Losada, 1963),

219 Ibidem.

220 Hibridaje es el término que Ernesto Sábato emplea al tratar el tema de la inmigración en el Río de la Plata y que se correspondería semánticamente con hibridación, término recogido en el Diccionario de la Real Academia de la Lengua Española. 
ideología del escritor va tornándose cada vez más conservadora hasta convertirse en colaborador activo del golpe de estado militar del general José Félix Uriburu el 6 de septiembre de 1930. En cuanto a la música de su país defiende con fervor el folclore criollo frente al tango, género al que califica como "reptil de lupanar":

«Pero, sea lo que fuere, si por la música puede apreciarse el espíritu de un pueblo; si ella es, como creo, la revelación más genuina de su carácter, el gaucho queda ahí manifiesto. El brío elegante de esas composiciones, su gracia ligera, su delicadeza sentimental, definen lo que hoy existe de música criolla, anticipando lo que existirá mañana. En aquella estructura, de suyo alada, está el secreto de su destino superior, no en las contorsiones del tango, ese reptil de lupanar, tan injustamente llamado argentino en los momentos de su boga desvergonzada. El predominio potente del ritmo en nuestras danzas, es, lo repito, una condición viril que lleva consigo la aptitud vital del engendro. La desunión corporal de la pareja, resulta posible y gallarda gracias al ritmo que así gobierno(sic) la pantomima, en vez de ser su rufián, como sucede con la "música" del tango, destinada solamente a acompasar el meneo provocativo, las reticencias equívocas del abrazo cuya estrechez exige la danza, así definida bajo su verdadero carácter». ${ }^{221}$

Más allá de lo que Lugones opinara sobre el tango como género musical nos interesa esa defensa a ultranza del gaucho y, sobre todo, de su condición viril. En este caso esa virilidad se vería representada en el ritmo de las danzas criollas, que permitirían un baile de pareja alejada, diferente al abrazo del tango. Traemos aquí de nuevo la concepción de danzas como el Malambo del que nos habla el Chúcaro como herramientas para competir en resistencia con otros hombres. Recordamos también que el alarde y la jactancia son muestras claras de masculinidad.

Para Lugones, el gaucho representa lo nacional y de hecho lo presenta como responsable de toda la historia argentina:

221 Leopoldo Lugones, El Payador. Hijo de la Pampa (Buenos Aires: Otero \& Co Impresores, 1916), 117. 
«Entonces hallamos que todo cuanto es origen propiamente nacional, viene de él. La guerra de la independencia que nos emancipó; la guerra civil que nos constituyó: la guerra con los indios que suprimió la barbarie en la totalidad del territorio; la fuente de nuestra literatura; las prendas y defectos fundamentales de nuestro carácter; las instituciones más peculiares, como el caudillaje, fundamento de la federación, y la estancia que ha civilizado el desierto: en todo esto destácase como tipo». ${ }^{222}$

Al comienzo de este análisis literario decíamos que eran pocos los escritores rioplatenses que no se habían interesado por el tango. De igual manera podemos decir que es muy habitual también encontrarnos en sus textos alusiones al gaucho, mucho más que a los tipos como el compadrito, que son posteriores. Lugones lo pone en el centro de la historia argentina como responsable directo y en cierta manera lamenta su desaparición. Nos interesa el empleo de palabras referentes a su masculinidad cuando lo describe. En el siguiente texto el escritor describe la desaparición voluntaria y varonil del gaucho y concluye con un metafórico epitafio en el que lo define, simplemente, como "hombre":

«Herido al alma, ahogó varonilmente su gemido en canciones. Dijérase que lo hemos visto desaparecer tras los collados familiares, al tranco de su caballo, despacito, porque no vayan a creer que es de miedo, con la última tarde que iba pardeando como el ala de la torcaz, bajo el chambergo lóbrego y el poncho pendiente de los hombros en decaídos pliegues de bandera a media asta. $Y$ sobre su sepultura que es todo el suelo argentino donde se combatió por la patria, la civilización, la libertad, podemos comentar su destino, a manera de epitafio, con su propio elogio homérico a la memoria de los bravos: "Ha muerto bien. Era un hombre». ${ }^{223}$

En este trabajo defendemos que la hombría y la virilidad eran cualidades que destacaban en el gaucho y que luego pasarían al compadrito. Que además sería algo que los hombres del tango adoptaron como seña de identidad y que, como muestra El Chúcaro en la coreografía que hemos

\footnotetext{
222 Ibidem, 71.

223 Ibidem, 73.
} 
presentado y que guía nuestro estudio, sirve como eslabón para unir esas dos músicas a veces incomparables: la música folclórica y el tango.

Su estricta educación católica y su aversión por lo italiano parece ser que fueron los motivos que llevaron a Lugones a rechazar el tango. Sin embargo, parece que, en la última etapa feliz de su vida junto a su enamorada Emilia, sí bailó alguno. Esta anécdota recuerda a una semejante que contaban de Borges quien, al parecer, a pesar de denostar públicamente a Gardel como cantor de tangos por considerarlo muy llorón, también se emocionó escuchándolo en casa junto a su hermana.

Volviendo a Lugones, Rodolfo J. Rossi nos explica en la revista Tango Reporter su aversión al tango:

«Dominado por un sentimiento claramente persecutorio es que en el año 1923 pronuncia en el Teatro Coliseo su famosa conferencia sobre "La doble amenaza". Esta era, para Lugones, la izquierda y el liberalismo. Estas dos fuerzas iban a echar a perder a la Argentina si en ésta no asumía el poder un líder fuerte, carismático, ungido por el óleo sagrado de Samuel. El quiebre definitivo se produce en 1929, y es cuando para Lugones, un hijo de Belcebú llamado Enrique Santos Discépolo, da a conocer el tango Cambalache. Analizada su letra, Lugones concluye que los italianos y el tango trabajaban de manera objetiva para el triunfo mundial del marxismo. Define la música ciudadana como "ese reptil de lupanar, tan injustamente llamado argentino en los momentos de su boga desvergonzada", y anuncia "ha llegado la hora de la espada"». ${ }^{224}$

Lugones fue, además, junto a autores como Ricardo Rojas o Manuel Gálvez un defensor a ultranza de la necesidad de una nueva educación que contribuyera a fomentar la argentinidad, estableciendo como figura central el gaucho. Lugones pensaba que el gaucho había sido la primera manifestación realmente argentina, diferente de los españoles y los indígenas. Por ello elevó el Martín Fierro de José Hernández como representación de la identidad

${ }^{224}$ Rodolfo J. Rossi, «Leopoldo Lugones: Vida y muerte de un enemigo del Tango» (2007), acceso el 25 de enero de 2021, http://tangoreporter.blogspot.com/2007/03/leopoldolugones-vida-y-muerte-de-un.html. 
nacional. En su libro El Payador analiza este texto y además hace un pormenorizado análisis de la figura del gaucho, su música y su poesía.

Es paradójico que, por una parte, algunos erijan el tango como uno de los símbolos más representativos de la identidad nacional y por otra, Lugones y su círculo denuesten este género precisamente porque lo ven "antinacional”. Sorprende además que en algunos círculos el tango y el folclore parezcan mundos tan alejados. Estos intelectuales que tanto criticaron a la generación del 80 buscaban más en las raíces y despreciaron el tango como símbolo nacional principalmente porque había surgido fruto de la mezcla de los argentinos con la inmigración europea. Nada más y nada menos que el hibridaje del que habló después Sábato. Pero también había bajo estos planteamientos cuestiones de tipo moral:

«Fue compartido el diagnóstico de los tres autores respecto al estado de crisis moral en que se encontraba el país y el reconocimiento de un presente decadente respecto a un pasado virtuoso. Según sus escritos, la Generación del '80 había corrompido las virtudes cívicas promoviendo el interés material por sobre los valores espirituales. Fueron sobre todo los inmigrantes quienes trajeron el germen materialista puesto que su principal interés radicaba en la conquista del éxito que excluía la idea misma de cualquier sacrificio por objetivos supraindividuales». ${ }^{225}$

También establecían una clara dicotomía interior-puerto:

«En consecuencia, para Gálvez tanto como para Lugones y Rojas, la cursilería porteña y su pedante materialismo se presentaban como una amenaza frente al interior del país, ya que su "idiosincrasia canallesca" tendía a expandirse por todo el territorio nacional causando mayor desnacionalización. Buenos Aires y Rosario aparecían así como ciudades tentaculares cuyo aire envenenado de gran ciudad-puerto se dilataba por todo el país generando en los pueblos vírgenes de invasores foráneos una metamorfosis de lo criollo-espiritual a lo cosmopolita-materialista» ${ }^{226}$.

225 Ibidem.
226 Ibidem. 
Y esto dicen sobre la música y, en concreto, el tango:

«Casi con la misma animadversión y equivalente tirria Gálvez profesa: "El litoral ha olvidado su música. Los inmigrantes, desalojando a los gauchos, han concluido con las canciones y los bailes criollos (...) En cambio tenemos ahora el tango, producto del cosmopolitismo, música hibrida y funesta. Yo no conozco nada tan repugnante como el tango argentino. Su baile es grotesco (...) y significa el más alto exponente de guaranguería nacional (...) en todas partes uno oye como castigo esa música fea y antiartística, lamentable síntoma de nuestra desnacionalización. $\rangle^{227}$

En contraste con estas expresiones destacan la importancia de mantener incólumes aquellas tonadas representativas del espíritu del pueblo. En este sentido, Lugones incluye en El Payador partituras de música tradicional argentina, como son algunas chacareras y otras canciones como «La media caña», «El Escondido», «El Gato» y «El caramba». Del mismo modo, Gálvez hace referencia a yaravíes, ruanitos y chacareras, "Ilenas de espíritu de la raza". Por lo tanto, las canciones y bailes son una revelación del alma nacional que debe preservarse y transmitirse, como veremos más adelante, por medio de la educación.

Describiendo la poesía argentina, Lugones dice: «El espíritu de nuestra poesía es como el de la música correspondiente: melancólico y viril a la vez». ${ }^{228}$ También en El Payador Lugones nos habla de la gallardía y el brío del hombre en las danzas, así como de la delicadeza que definiría el papel de la mujer ${ }^{229}$. Hablando en concreto de las zambas define su ritmo como viril ${ }^{230}$ y describiendo una chacarera destaca su armonía "ciertamente viril", distinguiendo entre los acordes propiamente dichos que serían más "masculinos" y los arpegiados que tendrían un carácter más "femenino". 231.

\footnotetext{
${ }^{227}$ Ibidem. Las palabras en cursiva corresponden a las que aparecen en negrita en el documento original.

${ }^{228}$ Leopoldo Lugones, El Payador. Hijo de la Pampa (Buenos Aires: Otero \& Co Impresores, 1916), 107

${ }^{229}$ Ibidem, 110.

$230 \mathrm{lbidem}$.

231 Ibidem, 114.
} 
Lugones no nos habla de los hombres protagonistas del tango, pero sitúa su origen en el lupanar. Además, las citas relativas a las opiniones de Manuel Gálvez y Ricardo Rojas establecen un camino o más bien una ruptura en el camino musical entre lo criollo y el tango. Afirman que los inmigrantes desalojaron al gaucho. Efectivamente, la vida del gaucho como había transcurrido hasta entonces cesa o cambia en el momento en el que se produce el proceso inmigratorio que está inmerso en el cambio al Estado Moderno. Pero, como deducimos de lo que El Chúcaro nos transmite en su cuadro, la virilidad del gaucho y su condición de hombre permanecerá en los protagonistas del tango, imbricados ya en la nueva vida del Río de la Plata.

Además, ha quedado claro que la virilidad, la hombría y en general la masculinidad eran cualidades aplicadas no solo a los hombres sino también a la música y los elementos que la componen. Así, se definen como masculinos aquellos aspectos que dan fuerza y determinación a una obra musical. Esto está presente en la teoría musical, por ejemplo, cuando se definen los finales de las obras musicales. De esta manera, si la pieza termina en el tiempo fuerte del compás se dice que el final es masculino y sería femenino si acabara en un tiempo débil. Los rasgos que definen estos elementos musicales son los mismos que el compadrito y sus semejantes heredarán del gaucho.

El último autor del que hablaremos en este capítulo y que, al igual que Lugones, fue muy crítico con el tango es Carlos Ibarguren.

Este escritor, político e historiador argentino fue una de las personalidades de su época más comprometidas con la historia, las raíces y la cultura argentina. Por ello, su defensa de lo folclórico en contraste con el tango es evidente en textos como el que sigue y que es un extracto de su libro De nuestra tierra, de 1917.

«Sin embargo, un producto ilegítimo que no tiene la fragancia silvestre ni la gracia natural de la tierra, sino el corte sensual del suburbio, ha corrido por todo el mundo deleitando a la clientela abigarrada de los hoteles europeos y de los cafés cantantes de las grandes capitales: el tango, que no es propiamente argentino; es un producto híbrido o mestizo, nacido en los arrabales y consistente en una mezcla de habanera tropical y de milonga falsificada. ¡Cuán distinto al crudo balanceo del tango es el noble y distinguido 
de la 'cueca', que se desenvuelve con una mímica tan aristocrática como la de una pavana o la de un minuet!» ${ }^{232}$

Encontramos aquí de nuevo la hibridación como germen del tango, siempre en el "sensual" suburbio, el arrabal. Al igual que Lugones, Ibarguren lo compara con la música folclórica y se ven claras las connotaciones morales tan dispares aplicadas a ambos estilos musicales. Creemos que esto tiene que ver con lo que decíamos al describir las danzas que existían en el momento en el que se gestó el tango: en las danzas folclóricas predomina la coreografía en grupo y, si es en pareja, los bailarines no se acercan mucho ni interactúan con la intensidad que exige el tango.

En definitiva y para ir cerrando este capítulo recordamos cómo lo empezamos y destacamos que la literatura y sus representantes pensaron, escribieron y hablaron del tango en muchos momentos diferentes y desde perspectivas diversas. Algunos lo criticaron, otros lo ensalzaron como elemento nacional y muchos formaron parte de su ambiente. A casi nadie pasó inadvertido. Pero este trabajo maneja dos conceptos básicos: el tango y la masculinidad. Es importante, por tanto, que destaquemos que también en los textos y autores analizados encontramos continuas referencias a la virilidad y a todas las cualidades que se relacionan con ella: la fuerza, la hombría, la determinación. Vemos que está presente desde nuestra referencia literaria más lejana en el tiempo, Facundo, de Domingo Faustino Sarmiento. También en las novelas del importante escritor argentino Eduardo Mallea encontramos la palabra 'viril' con mucha frecuencia. Podemos atrevernos a afirmar que en todos sus relatos aparece, por lo menos, una vez. Pongamos como ejemplo las siguientes citas de algunas de sus obras:

«Un viril acento en los hombros». ${ }^{233}$

${ }^{232}$ Carlos Ibarguren, De nuestra tierra (Buenos Aires: Sociedad Cooperativa Editorial Limitada, 1917), 17.

${ }^{233}$ Eduardo Mallea, La ciudad junto al río inmóvil, $5^{\mathrm{a}}$ ed. (Buenos Aires: Editorial Sudamericana, 1975), 13. 
«Sí, también a Solves parecía interesarle verdaderamente, virilmente, esa preocupación del individuo por trascendente». ${ }^{234}$

«Sus ojos llamaban la atención de las mujeres porque eran virilmente bellos». ${ }^{235}$

Podríamos llenar páginas enteras de referencias a los textos de Mallea en los que emplea esta palabra. Sería un trabajo interesante analizar qué quiere decir en cada una de sus alusiones a la virilidad, a qué se refiere, pero lo que a nosotros nos interesa es el poder de ese vocabulario de permanecer en el habla común. De alguna u otra manera la masculinidad está presente en las escenas que relata el escritor y del mismo modo permanece en los gestos de los bailarines, ya sea en su interpretación de un tango así como en carteles o fotografías que anuncien algún espectáculo relacionado con esta música.

A continuación, presentamos un mapa conceptual que nos sirve para resumir gráficamente la conexión entre lo que escribieron y opinaron los escritores de los que acabamos de hablar y la masculinidad que configura la imagen del tango rioplatense. Así, Evaristo Carriego, Marcelo del Mazo y Jorge Luis Borges habrían conectado el compadrito con el suburbio destacando sus dotes masculinas. Ricardo Güiraldes y Fernán Silva Valdés nos hablan de lo masculino a través de la figura del gaucho y Ernesto Sábato lo hace centrando su relato en la figura del inmigrante. Finalmente, hemos visto en Lugones, Rojas, Gálvez e Ibarguren un enfrentamiento entre tango y folclore en el que el elemento masculino y el alarde de virilidad juegan un papel determinante.

234 Ibidem, 58.

235 Ibidem, 202. 


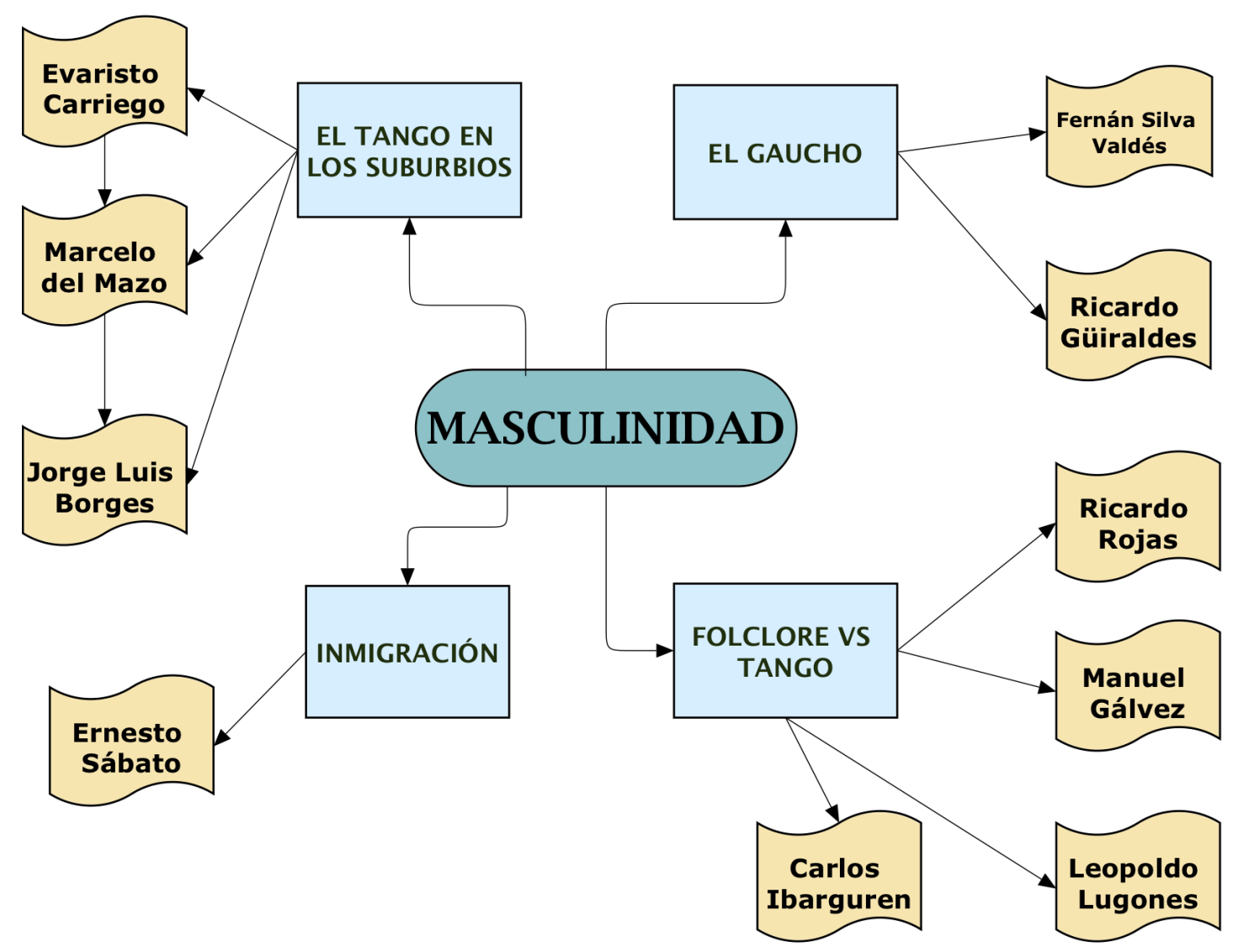

Figura 3. Mapa conceptual del reflejo de la masculinidad en la literatura argentina.

Además, y ya para finalizar, presentamos una tabla en la que situamos cronológicamente los textos literarios a los que nos hemos referido y las referencias más significativas de la historiografía del tango. Nuestra intención con esta tabla es presentar la simultaneidad de los discursos tanto académicos como literarios dando lugar así a una visión global del corpus de textos que han contribuido a configurar la imagen hipermasculinizada del tango. 


\begin{tabular}{|c|c|}
\hline FUENTES LITERARIAS & FUENTES HISTORIOGRÁFICAS \\
\hline $\begin{array}{l}1845 \text { Facundo, D. F. Sarmiento. } \\
1872 \text { Martín Fierro, José Hernández. } \\
1908 \text { Misas Herejes, E. Carriego. } \\
1910 \text { Los Venados, Marcelo del Mazo. } \\
1916 \text { El Payador, Leopoldo Lugones. } \\
1917 \text { De nuestra tierra, C. Ibarguren. } \\
1925 \text { El agua del tiempo, M. Del Mazo. } \\
1926 \text { D. S. Sombra, F. Güiraldes. } \\
1930 \text { Evaristo Carriego, J.L. Borges. }\end{array}$ & $\begin{array}{l}\text { 1903: «Tango criollo» en Caras y } \\
\text { Caretas. } \\
\text { 1913: El viejo tanguero. }\end{array}$ \\
\hline $\begin{array}{l}1936 \text { La ciudad junto al río inmóvil, E. } \\
\text { Mallea } \\
1953 \text { Tango. Discusión y clave. E.Sábato. }\end{array}$ & 1936 Historia del tango, H. Y L. Bates. \\
\hline 1959 La razón humana. E. Mallea. & $\begin{array}{l}1969 \text { La ciudad del tango, Blas } \\
\text { Matamoro. }\end{array}$ \\
\hline & $\begin{array}{l}1998 \text { El tango en la sociedad porteña, } \\
\text { Hugo Lamas y Enrique Binda. }\end{array}$ \\
\hline
\end{tabular}

Esta tabla nos sirve para entender de un modo rápido y visual, que cuando se escribe la que se considera primera historia del tango, ya pertenecían al imaginario popular los personajes y las anécdotas de las obras literarias que hemos analizado. Esas en las que se ensalzaba o se denostaba el tango y, lo que es más importante, en las que se hablaba del hombre y de la masculinidad tanto al referirse al gaucho como al compadrito del arrabal. Podemos deducir, por tanto, que la literatura fue una influencia importante para quienes empezaron a analizar los personajes y los ambientes del tango 
para así poder escribir y contar su historia, para la configuración de los imaginarios del tango y, en general, para la recepción del tango tanto dentro como fuera de Argentina.

\subsubsection{La masculinidad en las letras del tango rioplatense.}

Las letras de tango, principalmente en los comienzos del tango canción, se encuentran integradas en corrientes literarias diversas como son la estética modernista, las vanguardias y la poesía social. Conviven con el refinamiento lingüístico, la lucha por la libertad del verso y la representación de los conflictos sociales e identitarios. En este contexto nacen unos textos que, a pesar de los diversos temas que abordan, nos hablan, fundamentalmente, de uno solo. Podemos afirmar como premisa general para introducir esta parte de nuestro análisis que el tango habla, fundamentalmente, de sí mismo y, especialmente, en el pasado.

La lectura de las letras nos ha aportado una visión del género que tiene que ver con los intereses de sus protagonistas tanto internos como externos. Es decir, nos da información sobre el ambiente que describen y también sobre sus creadores, especialmente los letristas que, al fin y al cabo, forman parte de los protagonistas del género en la vida real. Por ello, será parte fundamental para nosotros el estudio de los intereses y la trayectoria de algunos de sus autores. También analizaremos la relación de estos tangos con algunos de sus intérpretes más importantes, como Carlos Gardel, Rosita Quiroga o Julio Sosa.

La fuente principal a partir de la que hemos trabajado para desarrollar esta parte de nuestra investigación es el amplio registro de letras de tango de la web Todo Tango, fundada por Ricardo García Blaya, estudioso del tango, y dedicada a la difusión de este género. En ella podemos encontrar trabajos de los más prestigiosos investigadores del tango y esta es una de las razones por las que la consideramos una fuente fiable que debíamos tener en cuenta. Además, miembros de la Academia Nacional del Tango de la República Argentina como el profesor Rubén Berenblum la avalan como un punto de documentación fiable y apto como fuente para trabajos de investigación. Buscábamos un registro de tangos en el que se hubiera seguido un criterio 
cronológico, pues entendíamos que eso facilitaría el trabajo de entender qué se quiso comunicar en cada momento. No encontramos ninguno tan completo como el de esta página. Sin embargo, después de leer las más de nueve mil letras de tango organizadas alfabéticamente, adquirimos una visión tan global y enriquecedora de lo que significa este género que nos dimos cuenta de que no era para nosotros necesaria la lectura de los tangos organizados por épocas. Además, nuestro trabajo ha requerido el análisis de aspectos relacionados con el tango en varias épocas diferentes. Podemos afirmar, por tanto, que este sitio web ha sido extremadamente beneficioso y lo tendremos siempre como referencia en futuros trabajos de investigación. Asimismo, han sido consultadas otras antologías que, si bien no son tan extensas, sí nos ofrecen análisis y comentarios que nos ayudan a entender los intereses generales de los letristas, o al menos cómo se ha afrontado, hasta ahora, su estudio. Es el caso de El día que me quieras. Antología de tangos de la editorial Lumen o el libro El tango en sus letras de Óscar del Priore.

Además de las antologías nombradas, también en otras que están editadas - tanto en papel como en formato digital- aparecen algunos rasgos comunes. Generalmente son listados en los que los tangos han sido seleccionados empleando un criterio que tiene que ver con su recepción. Es decir, son tangos que fueron escuchados y generalmente conocidos e integrados en el imaginario popular. En algunas de estas antologías, como sucede en la de Óscar del Priore, los autores nos presentan además un capítulo en el que analizan las temáticas más recurrentes, siendo estas, principalmente: el amor, el barrio y la nostalgia. Sin embargo, en este estudio afrontamos el análisis de las letras de tango desde otro punto de vista. Lo que nosotros buscábamos en el intenso trabajo de leer miles y miles de textos de canciones era responder a las siguientes preguntas: ¿en qué piensa y qué pretende un letrista cuando afronta la escritura de un tango? Y, por otro lado, ¿qué lenguaje selecciona para ello? Por eso no desechamos de nuestro análisis los tangos que no fueron muy conocidos, pues gran parte de lo que nos interesa tiene que ver con lo que el mundo cree $-\mathrm{y}$ creyó en algún momento- que es/fue el tango y qué pretendía contar. De hecho, muchos de los tangos de nuestra selección no aparecen en esas antologías. 
Nuestro trabajo analiza el impacto de la masculinidad en una creación estética que es la danza tango y cómo una visión de la historia de este género algo caricaturesca consiguió que se bailara en todo el mundo de un modo muy particular. Por ello, creemos imprescindible explicar cómo los personajes protagonistas de esta historia —compadritos, compadres, y en general los hombres que hacían gala de su hombría- configuraron el elemento principal en el que muchos de los poetas y letristas pensaron al afrontar la composición de un tango. Al mismo tiempo, el vocabulario perteneciente al campo semántico de la masculinidad es transversal en una cantidad de letras cuya temática no se centra específicamente en los hombres. Buscábamos referencias a los diferentes vocablos que existen relacionados con el varón y, por otro lado, a los personajes protagonistas de este mundo tan masculino. Pero estas referencias no sólo están en los tangos que hablan del submundo arrabalero, sino que, en muchos casos, llega a formar parte del lenguaje común empleado para hablar de casi cualquier tema.

Por tanto, es nuestra misión en esta parte del trabajo dedicada al análisis de las letras de tango establecer otro camino - que no excluye los anteriores - por el que la masculinidad, como principal carta de presentación del tango, haya podido llegar a nuestros días y configurar imagen común y universal en la danza y en general, en el contexto tanguero. Los otros caminos ya planteados serían los diferentes estilos de tango, la evolución en la danza plasmada en coreografía por Santiago Ayala el Chúcaro, los textos literarios y el modo en que ha sido contada la historia de este género rioplatense y de algunos de sus protagonistas como Carlos Gardel o Julio Sosa.

En cuanto al estudio de la masculinidad en las letras de tango encontramos algunos artículos interesantes, pero en general estos textos se basan solo en tangos muy conocidos por la población no experta y el enfoque casi siempre tiene que ver con el análisis de los personajes que describen. Presentamos como ejemplo de lo que pretenden estos estudios un extracto de uno de estos artículos:

«Es decir, antes que una constatación meramente verista de "los hechos", me interesa indagar en las letras como unos artefactos culturales por los cuales 
circulan ficciones de género que plantean mundos $y$, correlativamente, producen imaginarios». ${ }^{236}$

Además, esos trabajos no incorporan las nuevas investigaciones y no relacionan los textos tangueros con otros aspectos sensibles del género como son la danza o sus figuras más representativas.

Nosotros analizamos el elemento más inmediato y al mismo tiempo la materia prima que en el caso de las letras de tango es el vocabulario, al igual que lo son los gestos o la actitud en la danza. Para nosotros lo importante era conocer el tipo de palabras que habían escogido los autores de esas letras y relacionarlas con los intereses de sus autores puesto que, como veremos, son palabras que se popularizaron y que contribuyeron a la creación del mito masculino del tango. Veamos a continuación las conclusiones que pudimos extraer después de trabajar en nuestra ardua tarea de lectura.

Como ya se ha indicado, en la web Todo Tango están registradas nueve mil seiscientas cuarenta ${ }^{237}$ letras de tango. La lectura de todos estos textos sumerge a quien las lee en un mundo muy concreto y muy pequeño en el espacio y en el tiempo. Aunque existan tangos escritos en el siglo XXI o en lugares del mundo alejados del Río de la Plata, aunque los tangos nos hablen también de fútbol, de flores o de filosofía, siempre tendremos la sensación de encontrarnos en el arrabal rioplatense a finales del siglo XIX o comienzos del $X X$. Y esto sucede porque las referencias lingüísticas son muy concretas. No se trata de cantidad, sino de calidad y relevancia. El campo semántico del arrabal y del submundo urbano tiene tanta fuerza y es tan específico de este género que se constituye como protagonista, aunque haya muchos más personajes y muchas más historias que no sucedan en este ambiente. Dentro de este vocabulario arrabalero creemos que adquirieron especial fuerza las alusiones al hombre como ser fuerte, jactancioso, valiente y poco amigo de

\footnotetext{
236 Javier Gasparri, «Che Varón. Masculinidades en las letras de tango», Caracol, 2 (2011), acceso el 23 de abril de 2021, https://www.revistas.usp.br/caracol/article/view/57660/60715.

${ }^{237}$ Nuestro trabajo de lectura de estas letras finalizó el día 17 de octubre de 2020, por lo tanto, se deben tener en cuenta los textos registrados en la página web citada antes de esa fecha.
} 
mostrar sus sentimientos. Características que definían, sobre todo, como ya hemos visto, al compadrito y el resto de prototipos masculinos.

Hay muchos géneros como el bolero o la ranchera y hasta el rock que hablan de temas comunes en el tango como el amor, el abandono, la nostalgia, pero solo el tango nos sitúa en los márgenes de una ciudad en construcción como Buenos Aires. El protagonista de esta urbe es el hombre -entendido como ser masculino- por las razones que hemos explicado ya en capítulos anteriores y al producirse esa caricaturización de los personajes de la que hablamos al principio de este capítulo, se genera un submundo de malevos, milonguitas y puñales que consiguen convertirse - con la ayuda inestimable de los textos literarios- en protagonistas de la historia. De nuevo aclaramos - no nos cansaremos de hacerlo- que no es relevante en nuestro trabajo conocer los hechos históricos sino más bien necesitamos analizar esta parte mitológica y caricaturesca que, desde nuestro punto de vista, actuó como motor estético responsable del triunfo internacional del tango.

La letrística tanguera solo adquirió real importancia a partir de la década del 20, principalmente con el éxito de Carlos Gardel. Los tangos anteriores o bien tenían letra que no conocemos o aún no habían adquirido la forma que caracterizaría al exitoso tango-canción.

En el Apéndice A presentamos un listado formado por más de cuatrocientas letras en las que hemos encontrado referencias concretas a la masculinidad en el tango. Hemos seleccionado solo las que describen específicamente al hombre como ser jactancioso, mujeriego y valiente porque ese es el modo en el que se le representa a partir de un determinado momento en la sociedad y eso es lo que - en nuestra opinión — se recoge en la imagen de la danza tango. Pero, como se ha dicho ya, el vocabulario referente a la masculinidad está presente en muchos más tangos que tratan temáticas muy diversas. Si hubiéramos recogido toda referencia al hombre sin más la selección sería mucho más amplia. Por ello, otra de las conclusiones a las que llegamos después de la lectura de estos textos es que el mundo del tango es, fundamentalmente, masculino. Pero el hombre aparece representado en roles 
muy concretos. En su libro La ciudad del tango ${ }^{238}$, Blas Matamoro propone una serie de ejes a la hora de hablar de las letras de tango. Al tratar el eje referente a la familia apunta una idea que nos interesa mucho: en el tango no existe una figura paterna concreta, no hay referente masculino en la familia de esos protagonistas de los que nos habla este género. Parece que el tango se eleva como una subjetividad que sustituye al referente familiar o bien, una figura que restaría protagonismo a la figura central en la que se convirtió el compadrito. Según lo que nos cuenta Matamoro, de nuevo vemos la figura masculina como eje de toda temática tanguera. El hombre es el hijo, el bastardo, el abandonado, el que llora y enaltece la figura materna, el que reina en el arrabal. En definitiva, es la figura central del mundo letrístico, un submundo masculino adornado con figuras de milonguitas, costureritas y madrecitas buenas, entre otras.

Otro dato importante es que estos tangos seleccionados fueron compuestos en su mayoría en ese período de gran éxito del que hablábamos en el párrafo anterior, los años veinte y treinta. Recordemos que forman parte de la conocida como Edad de Oro del tango que incluye también los años cuarenta. En esta época dorada, y a través de la masculinidad exhibida en sus letras, se le da un nuevo impulso a la estética del tango. El "macho" representado en la literatura adquiere características, expresiones y un habla que se verán representadas hasta la saciedad en carteles, fotografías, películas y, lo que nos interesa más, en un modo de bailar y en todas las representaciones visuales que rodean a esa danza, aún en nuestros días. Veamos de una manera algo más pormenorizada qué encontramos en esos versos.

Cuando hablamos de referencias al tipo de hombre valiente y gallardo protagonista del arrabal nos referimos a versos como:

«iPero estando en la milonga/no se arruga el que es varón!...

... Los vivillos te persiguen y te rinden por cansancio,

las pebetas te provocan $\mathrm{y} \ldots$ jtenés que disparar!»». ${ }^{239}$

\footnotetext{
${ }^{238}$ Blas Matamoro, La ciudad del tango (Buenos Aires: Editorial Galerna, 1982), 117.

239 Jesús Fernández Blanco y Víctor Lomuto, «Actualidad porteña», Todo tango, Letras, acceso el 14 de junio de 2021,
} 
En muchos textos como este se presenta al hombre como una persona que no llora, no se rinde, que en todo momento se debe mantener firme. Hombres que luchan contra sus debilidades y las de otros hombres en los que se ven reflejados:

«Bajó el bacán la cabeza y él, tan rana y tan compadre, besándole los cabellos \|loró como una mujer». ${ }^{240}$

La parte masculina de la sociedad necesita reafirmarse como ser fuerte y muchas veces establece como antecedente la figura del gaucho del que heredará, además, un férreo código ético:

«Pa' condenarme mi amigo, primero me ha de escuchar,

y si después de escucharme, usted no encuentra razón,

puede con toda confianza condenar a este varón,

iqué naide ha visto achicarme y mucho menos temblar!

Y si me ha visto en el pago por los boliches chupar,

no es por el gusto 'e mamarme, ni sentirme perdido.

¡Es que una pena profunda me tiene tan abatido

que busco olvido en la caña, pa' no tener que llorar!».241

Al llevar a cabo la selección de los tangos nos dimos cuenta de que destacaban algunos autores si considerábamos la cantidad de letras que habían escrito en las que abundaba la temática y el vocabulario que nos interesa. Por encima del resto destacan dos: Celedonio Flores y Enrique Cadícamo, de cada uno de los cuales seleccionamos veintiséis tangos. Les seguirían Manuel Romero con quince, Ángel Villoldo con trece y Enrique Dizeo con once. Es, por tanto, misión indispensable saber quiénes fueron y cómo

https://www.todotango.com/musica/tema/6786/Actualidad-portena/. En citas posteriores y para no caer en reiteraciones incómodas para el lector, siempre que citemos letras de tango o poemas lunfardos registrados en la web Todo tango nos referiremos a ella como cfr. TTL.

${ }^{240}$ Celedonio Flores y José María Aguilar, «Lloró como una mujer», cfr. TTL, acceso el 14 de junio de 2021, https://www.todotango.com/musica/tema/193/Lloro-como-una-mujer/.

${ }^{241}$ José Sassone y Anselmo Aieta, «Gaucho», 1926, cfr. TTL, acceso el 14 de junio de 2021, https://www.todotango.com/musica/tema/1998/Gaucho/. 
vivieron estos cinco autores. Lo que sabemos ya es que, salvo Villoldo, los demás pertenecen a esa generación de letristas cuyos tangos triunfaron en las décadas del veinte y del treinta. Recordemos brevemente la trayectoria de todos ellos y cuáles fueron sus intereses.

Celedonio Flores fue un poeta y letrista argentino apodado El Negro Cele que vivió entre 1896 y 1947. Se crió en una casa del barrio de Villa Crespo -arrabales de la ciudad-, lugar en el que convivían criollos e inmigrantes. Se habla de él como poeta culto y popular y sobre todo destacó por su gran capacidad de reflejar la realidad que vivió de primera mano. Según él mismo contaba:

«Busco un pedazo de vida, la vivo intensamente en mi interior, la tomo en serio y despacito, y con cuidado, y voy haciendo el verso. Como he vivido un poco, como he dado muchas vueltas, como conozco el ambiente canalla, tengo la pretensión de vivir mil personajes. No soy de los que creen que el tango cómico sea la expresión de lo que siente el pueblo; sabemos todos que el tango es triste, como toda la música de nuestra tierra». ${ }^{242}$

En sus tangos empleaba un lenguaje propio del arrabal que le vio crecer en el que abundaba el léxico lunfardo y por ese motivo se dice que fue censurado por las autoridades de la dictadura instaurada en 1943. Su principal influencia -como la del resto de letristas de esas épocas- fue Pascual Contursi y escogió, como centro temático para sus textos, el arrabal y los personajes populares que lo protagonizaron. Colaboró con Gardel desde los años 20, quien inmortalizó tangos de su autoría como el imprescindible Mano a mano. Al igual que su amigo Enrique Dizeo —del que también hablaremosfrecuentó las tertulias, pero también las milongas, las timbas y los hipódromos. Nos interesa mucho el modo en que se describe la manera de escribir de Flores:

${ }^{242}$ Celedonio Flores. Cancionero (Buenos Aires: Torres Agüero Editor, 1977), 121. 
«No pretendo equipararlos intelectualmente, Celedonio tuvo más vuelo lírico. Su tono fue más empinado, más viril, más dramático. Sus tangos horadaron el terreno de la poesía.» ${ }^{243}$

Nos dice Gaspar Astarita que su tono era más viril y esto nos interesa sobremanera. Viril es una palabra casi protagonista en los textos que analizamos. Hablamos tanto de los textos literarios como de los más populares, entre los que incluimos las letras de los tangos. Recordamos que Enrique Mallea, por ejemplo, la empleaba en sus relatos para describir realidades diversas y en el tango aparece también de manera recurrente. En la mayoría de los casos, como en el ejemplo propuesto, entendemos que viril se podría equiparar a intenso, decidido y por extensión, relevante.

En cuanto a Celedonio Flores, Enrique Dizeo lo describe así en un poema:

«Es el coplero del pueblo escondido en la barriada.

¡Cuántas endechas caneras dispersó su inspiración!

Zorzal que trina a la gurda, sin pulimento ni nada

lo que brinda tiernamente su sensible corazón.

El canyengue del terruño, lejano del populacho

en su jerga arrabalera no hay quien le gane a cantar.

Bate el justo "Mano a mano" que tiene coco el muchacho;

¡si es un bate, sensa grupos, se sabe bien apilar!

Expresivas sus milongas cuando habla de la percanta

que se juega los morlacos del otario a la marchanta como idem el gato maula con el mísero ratón.

Conoce la gente pobre, las casitas de dos piezas

donde hay cachos de dulzuras

y pedazos de tristezas.

Donde Evaristo Carriego volcó toda su emoción». ${ }^{244}$

243 Gaspar Astarita, «Dos amigos: Enrique Dizeo y Celedonio Flores» en Tango y Lunfardo, 89 (1993), acceso el 20 de febrero de 2021, https://www.todotango.com/historias/cronica/77/Dos-amigos:-Enrique-Dizeo-y-CeledonioFlores/.

244 Enrique Dizeo, «Trovero», en Pablo Taboada, «Poemas a poetas. Parte I. Celedonio y Dizeo. Recuerdos de Julián Centeya», Investigación Tango, acceso el 17 de febrero 
Lo que está claro es que Celedonio Flores, pudiendo por su formación haber empleado un lenguaje más erudito, optó por el habla y el ambiente popular:

«No tengo el berretín de ser un bardo

chamuyador letrao ni de spamento;

yo escribo humildemente lo que siento

y pa' escribir mejor, lo hago en lunfardo.

Yo no le canto al perfumado nardo

ni al constelao azul del firmamento.

Yo busco en el suburbio sentimiento.

¡Pa cantarle a una flor, le canto al cardo!

Y porque embroco la cuestión que emana

del suburbio tristón, de la bacana,

del tango candombero y cadencioso,

surge a torrentes mi mistonga musa.

¡Es que yo tengo un alma rantifusa

bajo esta pinta de bacán lustroso! ». ${ }^{245}$

Representó los lugares y los personajes con los que creció y ayudó a configurar ese escenario tan mitificado de los arrabales de la ciudad. De nuevo encontramos al hombre como protagonista y los rasgos que hemos descrito al hablar de los diferentes tipos masculinos están en las letras de Celedonio Flores. Así describe el poeta la "estirpe porteña":

«Ya se acabó el taitaje que en mi barrio se imponía, porque era audaz y guapo, corajudo y peleador.

Que demostró su templaje donde caía

http://www.investigaciontango.com/inicio/index.php?option=com_content\&view=article\&id=1 25:celedonio-dizeo-y-centeya\&catid=43:poetas $\&$ Itemid $=63$

${ }^{245}$ Celedonio Flores, Cuando pasa el organito (Buenos Aires: Ed. Freeland, 1965), 25. 
y en cualquier talla que había/entró a tallar y copó.

$Y$ que en un entrevero,

se jugó entero,

por el cariño sincero

de la pebeta que amó». ${ }^{246}$

Encontramos en esta referencia otro lugar común del tango: el pasado. Es habitual que en las letras de tango se hable del arrabal como de un ambiente que pertenece al pasado. Se habla de él como de algo perdido, es un espacio y un tiempo que se echa de menos en el tango. Esto, indudablemente, ha contribuido a su mitificación. El tango habla de la leyenda pasada de los arrabales porteños, echa de menos la valentía de aquellos hombres, de sus entreveros, de sus milongas, nostalgia que también veíamos en Borges, por ejemplo. Esta idea encaja perfectamente con lo que podemos leer en La ciudad del tango de Blas Matamoro acerca de cómo el tango se establece como algo pasado, algo de lo que se habla, sobre lo que se escribe. El tango se convierte, definitivamente, en una estética:

«El tango es asumido como pasado en tanto forma, o sea repensado por el nuevo instrumento del conocer, y es proyectado hacia el futuro de su pervivencia como obra de arte específica. Asume así el carácter de una obra histórica, salvada para la memoria objetiva universal en la forma de la partitura.»1 ${ }^{247}$

Los años dorados de Flores fueron la segunda mitad de los veinte y los treinta y parece hablarnos continuamente de las orillas de la ciudad a finales del siglo XIX. En una de las milongas a las que puso letra se lamenta de que este estilo de música no tuviera nombre de varón y, de hecho, habla de ella en género masculino:

"Yo no sé de dónde vengo, ni sé para dónde voy.

${ }^{246}$ Celedonio Flores y Rosita Quiroga, «De estirpe porteña», cfr. TTL, acceso el 17 de junio de 2021, https://www.todotango.com/musica/tema/4154/De-estirpe-portena/.

${ }^{247}$ Blas Matamoro, La ciudad del tango (Buenos Aires: Editorial Galerna, 1982), 96. 
Sólo sé que soy porteño

y estoy bien adonde estoy.

Soy varón de rompe y raja,

pero qué le voy a hacer,

si por culpa del destino

tengo nombre de mujer.

Insulto que se hace gresca

en trastienda de almacén.

Penumbra de hace veinte años,

de farol a kerosén.

Me hicieron para cantarme

o pa' bailarme, según,

si no para tararearme:

¡Caran can cán!

¡Caran can fún!

¡Caran can cán!

¡Caran can fún!» ${ }^{248}$

Con los ejemplos expuestos queda claro que Celedonio Flores representó en sus textos ese ambiente arrabalero con el compadrito y otros tipos masculinos como protagonistas. La exaltación de lo masculino queda perfectamente explícita en sus tangos.

Aunque ya hemos aclarado que el éxito de los tangos que hemos seleccionado no es un criterio fundamental para nosotros a la hora de analizarlos, siempre es interesante tener en cuenta su recepción. La relevancia de sus letras tiene que ver, en parte, con su relación con Carlos Gardel quien, como ya hemos dicho, grabó algunos de sus temas: «Pan», «Viejo Smoking», «Canchero», «Por seguidora y por fiel» o «Lloró como una mujer». Gardel protagonizó la Edad de Oro del tango con letras, en los primeros años, de Pascual Contursi y posteriormente con las de jóvenes poetas como el Negro Cele. También Rosita Quiroga grabó muchos de sus tangos, como El as de los ases, y fue esta cantante, letrista y compositora,

${ }^{248}$ Celedonio Flores, Roberto Zerrillo y Fernando Martín, «Caran ca fún», cfr. TTL, acceso el 17 de junio de 2021, https://www.todotango.com/musica/tema/4162/Caran-ca-fun/. 
junto al sello Víctor, quien inauguró la era de las grabaciones eléctricas. Es indudable, por tanto, su relevancia en la época. En realidad, casi todos los tangos que hemos seleccionado de Celedonio Flores tuvieron cierto éxito.

Enrique Cadícamo, de quien también hemos seleccionado más de veinte letras, tiene una trayectoria tanto vital como profesional mucho más larga que la de Celedonio y algo posterior. El primer tango de Cadícamo es de 1925 - Pompas de jabón, con música de Roberto Goyeneche- y en esa época Flores ya vivía momentos de éxito. De hecho, Cadícamo hablaba de él como un referente imprescindible para letristas posteriores:

«Enrique Cadícamo, que consideraba a Flores "un poeta nunca igualado en su género", solía recordar que, cuando escuchó por primera vez el disco grabado por Gardel, los versos de "Margot" le parecieron "más que un poema lunfardo, una escuela, un modelo, una fuente donde tendrían que ir, forzosamente, a abrevar los autores de letras de tango en el futuro". 249

Sus tangos fueron grabados por los más importantes cantantes empezando por Gardel y pasando por Rosita Quiroga, Agustín Magaldi, Charlo o Libertad Lamarque. Fue uno de los autores más prolíficos del tango con unas mil trecientas canciones publicadas y en sus letras cupieron muchas temáticas. Además, vivió muchos años y viajó mucho, así que sería extraño pensar que no reflejara en sus letras diferentes espacios, tiempos y ambientes. Para él el tango era música sencilla, popular y esto se manifestaba —según comentó en alguna ocasión- en el hecho de que es música que se silba. Decía que se podría hablar del éxito de una canción popular si el pueblo la silbaba.

En la veintena de tangos que hemos seleccionado, Cadícamo nos transporta, de nuevo, al pasado. Son tangos escritos en la ya aludida Edad de Oro del tango - años veinte, treinta y cuarenta - y a través de ellos nos habla del tango de principios del siglo $\mathrm{XX}$, de los compadritos, las milongas, los

249 Juan Carlos Jara, Celedonio Flores. Por qué canto así (Buenos Aires: Ministerio de cultura argentina, 2015), 42. 
lugares y todo ello con gran nostalgia. En dos de los tangos tenemos una referencia concreta al año 1911:

«Ah, bailongo de ese entonces compadrón... bravucón... de 1911» ${ }^{250}$ y «milonga de aquel entonces que trae un pasado envuelto... de aquel 911 ya no te queda ni un vuelto...» ${ }^{251}$

Encontramos en estas letras de nuevo las alusiones a los guapos y compadritos, supuestos protagonistas del tango orillero. Ese hombre que es o debe ser como El Guapo de la Guardia Vieja:

«Fue testigo el barrio de audaces hazañas

que le consagraron Rey del compadraje

y las mozas lindas de garabitaje

bordaron su fama de guapo cantor...

$Y$ en serias payadas su filosa faca

al rival ladino basureó con arte

y fue su cuchillo glorioso estandarte

teñido en cien riñas de rojo color.

Guapo de la guardia vieja,

el de lengue y "aspamentos"

que por el mil novecientos

fuiste rey del arrabal...

Tus posturas conquistaron

a las paicas de rodete

$\mathrm{y}$ al andar tus firuletes

inventaron el gotán.

El guapo fue un resto de matrero

y paria que vivió su instinto rojo y primitivo,

prepotente, noble, valiente y altivo

con algo de bardo y de payador...

$Y$ fue por las calles del viejo suburbio

que pasó vencido con un gesto fiero

${ }^{250}$ Enrique Cadícamo y Gabriel Clausi, «Bailongo», cfr. TTL, acceso el 17 de junio de 2021, https://www.todotango.com/musica/tema/4483/Bailongo/.

${ }^{251}$ Enrique Cadícamo y Antonio Polito, «En lo de Laura», cfr. TTL, acceso el 17 de junio de 2021, https://www.todotango.com/musica/tema/511/En-lo-de-Laura/. 
el último taura que en los entreveros

se sintió bandido, gaucho y peleador...». ${ }^{252}$

En este tango encontramos los rasgos del estereotipo masculino de los arrabales del Río de la Plata y está presente en todos los textos de Cadícamo que presentamos en nuestra selección.

Otro de los letristas que hemos seleccionado por haber escrito una interesante cantidad de tangos en los que está presente la masculinidad es Manuel Romero. Este autor que vivió entre 1891 y 1954 era considerado un prototipo de porteño. Escribió ciento cincuenta letras, Gardel grabó diecinueve de ellas y tuvo mucho éxito en el cine con películas como, por ejemplo, Luces de Buenos Aires, dirigida por Adelqui Millar en 1931.

De nuevo nos encontramos con que los tangos seleccionados fueron compuestos en los años veinte y treinta. Podemos afirmar ya, pues, que existe un corpus interesante de textos escritos en la época dorada del tango en los que se hace apología y se exhiben de manera sistemática los rasgos varoniles de sus protagonistas.

Como primer ejemplo de la nostalgia del autor por los tiempos en los que un hombre era un hombre - por decirlo al modo del paradigma que estamos definiendo- traemos a colación el tango Carnaval de Antaño:

«Pucha qué lindos los carnavales de aquellos tiempos de hacha y tiza en el Pilar.

¿Dónde se encuentran ya?

¿Qué fue del tiempo aquel?

Cuando me acuerdo/se me eriza hasta la piel.

Hoy los pitucos, en los balcones, se degeneran con batallas de papel.

En aquel tiempo, che,

252 Enrique Cadícamo y Ricardo Cerebello, "Guapo de la guardia vieja», cfr. TTL, acceso el 17 de junio de 2021, https://www.todotango.com/musica/tema/1130/Guapo-de-laguardia-vieja/. 
un hombre de verdad/fajaba a un tipo o se iba al tacho su cartel.

¿Te acordás del carnaval de 1912,

que tallaba en el Pigall/

a patota de los Posse?

¿Te acordás de aquel festín

en aquel peringundín,

allá por Rodríguez Peña,

que acabó con botiquín?

¿Y la biaba que cobró

aquel pobre cocoliche

que tocaba el acordeón

en la puerta de un boliche?

¡Qué lindo tiempo aquel!

¡Qué lindo carnaval!

Las cosas terminaban en la puerta 'el hospital.

¡Pucha qué lindos los carnavales

de aquellos tiempos que no pueden ya volver!

Mujeres de cartel,

guapeza sin igual

y en medio 'el baile el relumbrón de algún puñal.

Hoy los muchachos, con serpentinas,

en los balcones se entretienen en jugar.

En aquel tiempo, che,

un taita de blasón

largaba tiros pa' farrear desde un balcón.

Pucha qué lindos los carnavales

de aquellos tiempos del bufoso y del facón.» ${ }^{253}$

Además de la nostalgia por tiempos anteriores, Romero nos habla en estos tangos de amor, especialmente son quejas que aluden a algún desengaño o abandono. Es recurrente en estos lamentos el empleo de frases como «un hombre macho no debe llorar», «eran otros hombres más hombres los nuestros» o «para eso hay que ser hombre decidido y haber nacido taura

253 Manuel Romero y Sebastián Piana, «Carnaval de antaño», cfr. TTL, acceso el 17 de junio de 2021, https://www.todotango.com/musica/tema/886/Carnaval-de-antano/. 
de acción, como los de antes, que en la partida, por una paica se jugaban la vida». Estos fragmentos los hemos extraído de los tangos «Tomo y Obligo», «Tiempos Viejos» y «Malevaje de antaño», respectivamente. En definitiva, esa visión de la masculinidad entendida como una necesidad de mantenerse al margen de los sentimientos y un ansia de mantenerse siempre firme, valiente y dispuesto en los enfrentamientos. Muchos de estos tangos fueron grabados por grandes intérpretes, entre ellos Carlos Gardel. Además, Romero estrenaba sus tangos en sus obras de teatro y en el cine. Es el caso, por ejemplo, de «Tomo y obligo».

Enrique Dizeo es otro de los autores en algunas de cuyas letras hemos encontrado alusiones a la masculinidad o a la virilidad y, como casi siempre, en el contexto del arrabal de comienzos del siglo XX. Vivió entre 1893 y 1980 por lo que tuvo, al igual que Cadícamo, una dilatada trayectoria. Fue un bohemio aficionado al turf que intentó, como veíamos también en los casos anteriores, representar la ciudad, la calle y el barrio. Gardel grabó alguno de sus tangos. En su canción más famosa, «Andate con la otra», ya encontramos la expresión «te hice un hombre de verdad» y en sus tangos «Bicho raro», «Cancha», «Con qué ventaja», «Echaste buena», «El encopado», «Garufa en Villa Lugano» y «Andate con la otra» nos presenta a ese varón que no puede faltar en un lugar de reunión donde siempre se necesite alguien que, en caso de necesidad, saque un facón:

«Nunca falta un buen varón que ronque y que pegue fuerte, que se manque alguna muerte, merengue que hay que evitar. Ya que vamo' a milonguear, que nos ayude la suerte». 254

${ }^{254}$ Enrique Dizeo y José Canet, «Garufa en Villa Lugano», cfr. TTL, acceso el 17 de junio de 2021, https://www.todotango.com/musica/tema/4117/Garufa-en-Villa-Lugano/. 
Ángel Villoldo es considerado por muchos el padre del tango y se preocupó siempre de reflejar en sus textos el habla popular de la gente más sencilla. Nació décadas antes que los autores de los que ya hemos hablado y murió cuando estos aún no habían conseguido el éxito con sus canciones. Parecería que se escapa de ese conjunto de textos de los que estamos hablando y que podemos situar en la Edad de Oro del género y así es. La relevancia de estas letras es precisamente esa, son las más antiguas y pertenecen a un compositor de referencia en la composición de tangos.

En páginas anteriores hablábamos de la influencia que Pascual Contursi supuso para los letristas del conocido como tango canción por ser su principal referente. Contursi abrió el camino de ese tango de temática humana, de desengaños, de amores, de nostalgias. Se separaba así del tango primitivo algo más picaresco. Este tango de los comienzos estaba representado principalmente por las letras de Villoldo y en su repertorio encontramos también los más antiguos textos - de los que hemos tomado como referencia en nuestra fuente- que describen al hombre de la milonga arrabalera. Estos son: «Calandria», «El criollo más criollo», «El más pesao», «El terrible» y «El torito». Veamos un ejemplo de cómo Villoldo nos habla ya antes de la década del 20 del hombre de principios de siglo:

«Aquí tienen el criollo más criollo,

el que hasta aura ha encontrado rival

el chinito más pierna y compadre

que ha pisado por la capital.

Si hay un turro que sepa hamacarse

que se venga lo voy a esperar

para hacer unas cuantas quebradas

de este lindo tanguito al compás.

Así podremos ver cuál es más taura,

a la voz de aura,

para bailar.

Moviendo nuestros cuerpos cual resortes,

dos o tres cortes

vamos a dar. 


\footnotetext{
¿Dónde están esos turros gritones

que de taitas a veces las dan

y que quieren llevarse la palma,

porque dicen que saben bailar?

No dirán de que es pura parada

y sin plata la vengo a copar;

pa' ganarme tendrán que hamacarse,

y de arriba no la han de llevar.

$Y$ vean, pues, señores, que no miento,

y que no es cuento/lo que formé.

Pa' cortes y quebradas no hay ninguno

por más toruno

que me la dé. ${ }^{255}$
}

De algunos no hemos encontrado fecha de composición, pero Villoldo, como ya hemos dicho, muere en 1919 y para entonces aún no había triunfado realmente el tango canción. Sirva como referencia cronológica el hecho de que en 1917 el dúo Gardel-Razzano graba su tango "Cantar eterno». Gardel todavía no era el cantante de referencia como principal representante del tango canción. No había comenzado aún la Edad de Oro del tango.

Para terminar esta parte de nuestro trabajo dedicada a las letras de tango $\mathrm{y}$ antes de proponer unas breves conclusiones finales vamos a presentar ejemplos de tangos compuestos por letristas de importancia en los que, de nuevo, lo masculino, lo viril y la hombría son los protagonistas.

Comenzamos con Homero Manzi y su tango Eufemio Pizarro de 1947:

«Morocho como el barro era Pizarro,

señor del arrabal;

entraba en los disturbios del suburbio

con frío de puñal.

Su brazo era ligero al entrevero

255 Ángel Villoldo, «El criollo más criollo», cfr. TTL, acceso el 17 de junio de 2021, https://www.todotango.com/musica/tema/3544/El-criollo-mas-criollo/. 
y oscura era su voz.

Derecho como amigo o enemigo

no supo de traición.

Cargado de romances y de lances

la gente lo admiró.

Quedó pintado su nombre varón

con luz de luna y farol,

y palpitando en mañanas lejanas

su corazón.

Decir Eufemio Pizarro

es dibujar, sin querer,

con el tizón de un cigarro

la extraña gloria con barro y ayer

de aquel señor de almacén.

Con un vaivén de carro iba Pizarro,

perfil de corralón,

cruzando con su paso los ocasos

del barrio pobretón.

La muerte entró derecho por su pecho,

buscando el corazón.

Pensó que era más fuerte que la muerte

y entonces se perdió.

Con sombra que se entona en la bordona

lo nombra mi canción». ${ }^{256}$

El prototipo de hombre valiente y viril es reclamado por una mujer en el tango Maula, de Víctor Soliño, compuesto en 1927:

«No pises el cotorro

que no te puedo ver.

No ves que hasta vergüenza

me da ser tu mujer.

Yo quiero, pa' que sepas

256 Homero Manzi y Cátulo Castillo, «Eufemio Pizarro», 1947, cfr. TTL, acceso el 17 de junio de 2021, https://www.todotango.com/musica/tema/229/Eufemio-Pizarro/. 
tener siempre a mi lado

a un hombre bien templado,

no a un maula como vos.

A un hombre que se juegue,

si llega la ocasión,

la vida en una carta,

sin sentir emoción.

A un hombre que sea hombre

y sepa responder

y no llore cobarde,

igual que una mujer.» ${ }^{257}$

También lo viril es protagonista de alguno de los tangos del colaborador de Piazzolla y director durante muchos años de la Academia Nacional del Tango, Horacio Ferrer:

«Su voz, un gusto de magnolia macho, los muslos duros de saber volver. [...]

Su boca encinta de un misterio bravo, diez hembras hondas te empujó a crecer, porque en tu pelo y tu silencio largos, veinte varones él sabía ser. ${ }^{258}$

Otro letrista considerado entre los más grandes del tango fue Homero Expósito, autor junto a su hermano Virgilio de tangos tan importantes como «Naranjo en Flor», por nombrar solo uno. Pues bien, también Expósito quiso describir al compadrito milonguero en alguno de sus textos:

«Sabrán que soy el Entrerriano, que soy milonguero y provinciano,

${ }^{257}$ Víctor Soliño y Adolfo Mondino, «Maula» 1927, cfr. TTL, acceso el 17 de junio de 2021, https://www.todotango.com/musica/tema/2246/Maula/.

${ }^{258}$ Horacio Ferrer y Astor Piazzolla, «Balada para él», cfr. TTL, acceso el 17 de junio de 2021, https://www.todotango.com/musica/tema/2318/Balada-para-el/. 
que soy también/un poquito compadrito

y aguanto el tren/de los guapos con tajitos.

$Y$ en el vaivén

de algún tango de fandango,

como el querer

voy metiéndome hasta el mango,

que pa'l baile y pa'l amor

sabrán que soy

siempre el mejor. ${ }^{259}$

Enrique Santos Discépolo fue conocido como «el filósofo del tango». Cuando empezó a presentar sus composiciones en los años veinte, el público aclamaba los tangos de Celedonio Flores o Manuel Romero, por nombrar dos de los letristas de los que hemos hablado en este epígrafe. Actualmente sus temas son algunos de los más escuchados del género y, posiblemente, de los que hemos recogido en nuestra selección el más representativo —en lo que al impacto de la masculinidad se refiere_ es «Malevaje», de 1929:

«Decí, por Dios, ¿qué me has dao,

que estoy tan cambiao,

no sé más quien soy?

El malevaje extrañao,

me mira sin comprender...

Me ve perdiendo el cartel

de guapo que ayer

brillaba en la acción...

¿No ves que estoy embretao,

vencido y maniao

en tu corazón?

Te vi pasar tangueando altanera

con un compás tan hondo y sensual

que no fue más que verte y perder

259 Hormero Expósito y Rosendo Mendizábal, «El entrerriano», cfr. TTL, acceso el 17 de junio de 2021, https://www.todotango.com/musica/tema/2372/El-entrerriano- [Exposito]/. 


\author{
la fe, el coraje, \\ el ansia 'e guapear. \\ No me has dejao ni el pucho en la oreja \\ de aquel pasao malevo y feroz... \\ ¡Ya no me falta pa' completar \\ más que ir a misa e hincarme a rezar! \\ Ayer, de miedo a matar, \\ en vez de pelear \\ me puse a correr... \\ Me vi a la sombra o finao; \\ pensé en no verte y temblé... \\ ¡Si yo, —que nunca aflojé- \\ de noche angustiao \\ me encierro a yorar [sic.] !... \\ Decí, por Dios, ¿qué me has dao, \\ que estoy tan cambiao, \\ no sé más quien soy?» ${ }^{260}$
}

Hasta aquí, el análisis de la masculinidad en las letras de tango. Esta parte de nuestro trabajo nos ha permitido concluir, fundamentalmente, dos ideas: los principales letristas del género emplearon en sus composiciones el alarde masculino como centro de sus historias, pero también en pasajes casuales. Además, los tangos que presentan al hombre con los rasgos que más adelante se exagerarán y se plasmarán en diversos ámbitos del género rioplatense como la danza pertenecen en su mayoría a la época dorada del tango. También hemos podido ratificar que el tango es fundamentalmente masculino y que es un recuerdo del pasado.

Cuando en los años veinte empieza a popularizarse una manera de contar historias a través de esta música, el tango se convierte en una música carismática con unos códigos muy concretos. Empieza a hablar de sí mismo y de su ambiente. El hombre protagonista de este mundo - mundo que, recordamos, ya no existe- tiene unas características muy concretas y se

260 Enrique Santos Discépolo y Juan de Dios Filiberto, «Malevaje», cfr. TTL, acceso el 17 de junio de 2021, https://www.todotango.com/musica/tema/41/Malevaje/. 
presenta como un ser valiente, frecuentemente mujeriego, jactancioso y amigo del enfrentamiento y del facón. Para representar estos ambientes, los letristas necesitaron un vocabulario y unas expresiones concretas. Así, encontramos en repetidas ocasiones términos como los siguientes: malevo, compadre, macho, viril, llorar como una mujer, jugarse la vida, entrevero, aflojar, madrecita y muchos más.

De las nueve mil cuatrocientas sesenta letras que hemos leído, casi quinientas han sido seleccionadas por nosotros por contar entre sus versos con estas expresiones y por presentar al hombre como lo que acabamos de describir. Sin embargo, eso no significa que en las canciones no seleccionadas no aparezca ese lenguaje. Lo que hemos pretendido ha sido escoger las más evidentes muestras de la apología de una masculinidad que en un momento dado sería representada también a través de la danza.

Es importante recordar que al hablar de la composición de letras de tango estamos poniendo el foco en la fase previa a la composición y al comenzar a hablar de esto nos preguntábamos ¿en qué piensa un poeta a la hora de afrontar la escritura de un tango? ¿qué vocabulario selecciona? Esto ha sido fundamental para nosotros a la hora de buscar respuestas en los textos tangueros y, pese a que también nos ha parecido necesario hacer cierta alusión a ello, no le damos excesiva importancia a que los tangos fueran más o menos conocidos en la época.

Si bien, lo que sí es verdaderamente relevante es que estas letras vieran la luz en la época de mayor auge del género y no sólo porque pudieran tener mayor repercusión sino porque la consecuencia directa de este hecho fue que a través de sus textos, al igual que sucedió en el ámbito literario, el propio tango contribuyó a alimentar su leyenda de género protagonizado por figuras hipermasculinizadas. Cuando analicemos los distintos estilos de tango veremos cómo la exagerada masculinidad en los gestos de los bailarines se aprecia fundamentalmente en los estilos diferentes al de los comienzos o al canyengue, que sería el que se considera popularmente como el primitivo, hecho que desmentiremos en su debido momento. La razón es que cuando se bailaba el tango en romerías y fiestas familiares era simplemente un baile popular y aún no se hablaba de él ni se habían creado excéntricas historias 
con él como protagonista. Simplemente, se bailaba. Recordemos que la primera obra considerada como un intento de plantear una historia del tango es de 1936, en plena Edad de Oro: la ya mencionada Historia del Tango de Luis y Héctor Bates.

\subsubsection{El tango y la masculinidad en el vocabulario lunfardo.}

En el estudio de cualquier tema relacionado con el lunfardo es obligada la consulta de los trabajos de dos de los más importantes expertos en el tema. En primer lugar, José Gobello, periodista argentino y fundador de la Academia Nacional del Lunfardo y cuya primera obra dedicada al lunfardo, Lunfardía, data de 1953. Fue durante mucho tiempo el único referente en el estudio de este habla popular. Otro de los expertos cuyo trabajo, actualmente, es imprescindible, es Oscar Conde, autor de Lunfardo y Diccionario Etimológico del lunfardo, entre otros.

Al abordar la lectura de estos textos cronológicamente nos topamos con las primeras páginas de Lunfardía de Gobello donde podemos leer:

«Los amigos del tango se regodean todavía con las viejas letras guarangas, nacidas cuando el jopo era patente de hombría y el taquito militar redoblaba, viril, en la noche porteña». ${ }^{261}$

Cuando Gobello dice esto el tango se está secando, está ya en decadencia y, al igual que sucedía en las letras, habla de un tiempo pasado incluyendo en una sola frase las palabras hombría y viril.

Líneas después lo pone de actualidad —teniendo en cuenta que está escrito en los años cincuenta- asegurando que «canta todavía la ciudad por las esquinas, en las noches ya sin compadres ni cuchillos» ${ }^{262}$.

Para Gobello «lunfardo es todo término, cualquiera fuere su origen, que el hablante de Buenos Aires utilice en oposición a los que le propone la lengua maternal» ${ }^{263}$. De nuevo el pasado, el tango, el compadre, el cuchillo, términos

\footnotetext{
261 José Gobello, Lunfardía (Buenos Aires: Argos, 1953), 1.

262 Ibidem.

263 José Gobello e Irene Amuchástegui, Vocabulario ideológico del Lunfardo (Buenos Aires: Editorial Corregidor, 1998), 9.
} 
que hemos repetido en este trabajo hasta la saciedad y que, como ya queda para nosotros demostrado, retratan la influencia de la masculinidad en el relato de los primeros años del tango.

Pues bien, Gobello sitúa de esa manera el lunfardo y a continuación aclara que este lenguaje no surgió — como se decía popularmente- en las cárceles. Si bien fue empleado y desarrollado por lunfardos ${ }^{264}$ el vocabulario se creó fruto de la confluencia de tantas lenguas como trajo consigo el intenso proceso inmigratorio. En el prólogo del libro de Gobello Aproximación al Iunfardo Julián Cáceres Freire afirma que el lunfardo fue empleado por el compadrito - al que atribuye cierto grado de gauchismo y ruralismo-, que este, a su vez, fue uno de los personajes que dio color y acción al tango y que las letras de este género actuaron como un importantísimo agente difusor del lunfardo ${ }^{265}$.

A su vez, Oscar Conde —adhiriéndose a la opinión de su predecesortambién sitúa el origen del lunfardo en el compadrito, aunque atribuye su difusión a «autores de folletines, los costumbristas, los periodistas, los letristas de tango, los autores de sainetes y los poetas lunfardescos» ${ }^{266}$. Vemos en estas referencias una clara relación entre compadrito, tango y lunfardo. Esta es una de las razones por las que, al hablar de masculinidad en el tango, no podíamos olvidarnos de reservarle un espacio en nuestras páginas al lenguaje porteño.

Magali Saikin ofrece un punto de vista diferente relacionándolo con la homosexualidad. Según nos cuenta esta investigafora, al igual que siempre se afirmó popularmente que el lunfardo era un lenguaje empleado por los delincuentes para hablar entre ellos y no ser entendidos por las fuerzas de seguridad, ella lo pone en boca de los homosexuales ${ }^{267}$. Nos relata cómo, al perder vigencia la teoría que relacionaba lunfardo con delincuencia, cobra

${ }^{264}$ El vocablo lunfardos significa 'delincuentes'.

265 José Gobello, Aproximación al lunfardo (Buenos Aires: Ediciones de la Universidad católica argentina, 1996), 15.

266 Oscar Conde, Lunfardo. Un estudio sobre el habla popular de los argentinos. (Buenos Aires: Taurus, 2011), 373.

${ }^{267}$ Magali Saikin, Tango y género. Identidades y roles sexuales en el Tango Argentino (Stuttgart, Editorial Abrazos, 2004). 
más fuerza aquella que intenta explicar cómo los homosexuales se relacionaban entre sí por medio de esta habla. En concreto, empleaban el vesre, sistema de inversión de las sílabas en una palabra que aún actualmente podemos observar en vocablos comunes en el habla rioplatense como jermu o gotan.

Es especialmente interesante el libro escrito mano a mano entre José Gobello e Irene Amuchástegui, titulado Vocabulario Ideológico del Lunfardo. En este trabajo los autores agrupan los términos lunfardos teniendo en cuenta categorías ideológicas. Es decir, según su significado y el contexto en el que se emplean pertenecen a uno y otro grupo de palabras. Este texto ha sido muy esclarecedor para nosotros porque aporta un contexto al vocabulario que presenta. Así vemos, por ejemplo, que los referentes ideológicos alrededor de los que se agrupan más cantidad de palabras son, por este orden, las categorías robo — con 279 voces-, sexo —con 171- y tipos —con 112-. Es decir, estas son las categorías semánticas para las que se inventaron mayor número de palabras. Robo, sexo y tipos son términos relacionados casi exclusivamente con el hombre, por ello no es de extrañar que, de todas las palabras enumeradas, por ejemplo, en la categoría tipos, solo cuatro se refieren a mujeres.

Además, nos encontramos también en este libro un grupo de palabras cuya categoría, es decir, el concepto que comparten es jactancia. Al abrigo de esta idea Gobello y Amuchástegui reúnen sesenta y ocho palabras que tienen que ver con el hecho de que una persona alardee de sus cualidades — sean reales o no- y presuma de sí misma. De estos vocablos quince son verbos y el resto sustantivos masculinos. Es inevitable relacionar todas estas palabras con la figura del compadrito y debemos también recordar cómo, en las letras de tango analizadas, la figura masculina habitualmente se presentaba como un ser vanidoso y presumido. De hecho, en este listado de palabras relacionadas con jactarse y presumir encontramos la familia léxica de compadrito: compadrada, compadraje, compadre, compadrear, compadrito y compadrón. También acciones que aparecen en este libro como 'darse dique', 'darse corte' o 'cacarear' reflejan la personalidad de un hombre que necesitaba demostrar su hombría y hacer apología de su masculinidad. Al 
menos, eso vemos en el relato de la historia del tango, en la coreografía de El Chúcaro, en muchos textos literarios, en las letras de tango y lo veremos en las figuras de Carlos Gardel y Julio Sosa, o en lo que nos contaron sobre ellos.

A continuación, vamos a analizar algunos de los poemas lunfardos en los que encontramos este alarde de masculinidad. Veamos por quiénes y cuándo fueron escritos, qué querían transmitir y qué vocabulario emplearon los poetas para ello.

En «A la edad de los varones» Otilia da Veiga, actual directora de la Academia Nacional del Lunfardo, nos describe las diferentes etapas en la vida de un hombre. Según escribe da Veiga, los cambios que se producen en la vida de un hombre están definidos por sus intenciones y habilidades en la conquista de una mujer. Comienza a los quince siendo solo una promesa, entre los veinte y los treinta disfruta de su plenitud y a partir de ahí comienza la decadencia hasta que cualquier 'relojeo' es una conquista ${ }^{268}$.

Las figuras masculinas como el guapo, al igual que en el tango, también son protagonistas de algunos de los poemas lunfardos. Carlos de la Púa describe así el ambiente malevo de compadritos y entreveros:

«Mi macho es ése, que ves, ipinta brava!

de andar candombe y de mirar tristón.

Su pañuelo oriyero lo deschava

y lo vende su funyi compadrón.

Milonguero, haragán y prepotente,

mancusa al verres y pasa a lo bacán.

Las horas las divide entre el far-niente, la timba, la gayola y el gotán.

Ortivan los otarios de yuguillo

que me insulta, me casca y cafichea.

¡Mejor! De ellos me tira su bolsiyo, y de mi macho, todo lo que sea.

268 Otilia da Veiga, «A la edad de los varones», cfr. TTL, acceso el 17 de junio de 2021, https://www.todotango.com/musica/tema/2990/A-la-edad-de-los-varones/. 


\author{
Remanyado canchero en la avería, \\ su vida de malevo es un prontuario. \\ Él me enseñó las dulces pijerías \\ para engrupir debute a los otarios. \\ El precio de mi cuerpo en los amores \\ le da chele en su vicio, el escolazo, \\ y aplaca como nada los furores \\ que me anuncia casi siempre el cachetazo. \\ ¡Ese es mi hombre! Canallesco, inmundo, \\ es mi vida, mi morfi, mi pasión. \\ No lo cambio por todo lo del mundo... \\ Sus biabas me las pide el corazón». ${ }^{269}$
}

Al hablar de las letras de tango, vimos cómo Celedonio Flores había intentado reflejar en sus textos la vida del barrio que lo vio crecer, Villa Crespo. Allí sitúa el poeta el ambiente que nosotros definimos como eminentemente masculino. Pues bien, también parece ser este su objetivo en los poemas lunfardos. Una muestra clara de ello es el poema que lleva el nombre de su barrio. Lo reproducimos entero porque representa claramente lo que Flores quería expresar no solo en este poema sino en otros como «Azucena», «Bulín», «Chorro u Oro viejo»:

«Barrio piringundín, barrio malevo

donde aprendí a mancar la vida maula

en mis días papusos de purrete

compadrito y piernún, callao y taura.

Barrio de contras bravas, tus hazañas

que rubricaron fieras puñaladas

deberían saberlas los mocosos...

En la escuela tendrían que enseñarlas...

Mirador de Seghezo, arquitectura

estilo medieval..., medio-romántica:

${ }^{269}$ Carlos de la Púa, «La canción de la mugre», cfr. TTL, acceso el 17 de junio de 2021, https://www.todotango.com/musica/tema/1267/La-cancion-de-la-mugre/. 
parecía decir con voz de macho:

el que no es malandrín, de aquí no pasa.

La quinta de la Lunga, los perales, tentación de pandillas malandrasas, entrevero de piernas y de alambres cuando el tano tiraba la mancada. La academia San Jorge, la academia... donde cobraban cinco la bailada; "Si me habré compadriao mis chirolitas despatarrando cortes y quebradas".

El Mocho, el Cachafaz, Pata de Alambre,

David, La Portuguesa y el Lagaña; los hermanos Balijas y Fresedo (El pibe Paternal, de larga fama). Allí manqué debute las miserias de los fiocas varaos a pan y agua, y el amor que se acaba en el ayuno del que quiere vivir de salto y carta. El café Venturita y los Istueta, los matinés y los bailes de Peracca. El café La Morocha y el barbijo de Arolas, compadreándole en la cara.

Arroyo Maldonado, barbijo taura que en las aguas del Plata desangraba, cara al sol, como un hombre sin renuncios del que acecha en la sombra y no da cara. Arroyo Maldonado, cuneta rea, agua-fuerte brutal de mi barriada, hablar de Villa Crespo y no nombrarte es tirar las palabras a una zanja...

Es decir que a este barrio milonguero como a vos lo ha tapado la ignorancia... Yo florezco en jardines con mis versos, vos ahora no sos más que una cloaca...». ${ }^{270}$

${ }^{270}$ Celedonio Flores «Villa Crespo», Cancionero (Buenos Aires: Torre Agüero, 1977), 108. 
De nuevo el barrio, la delincuencia y la milonga con el hombre, 'la voz de macho', como protagonista.

Hemos encontrado veinticuatro poemas ${ }^{271}$ en los que, nuevamente, el protagonista hace alarde de hombría, o donde el poeta destaca las cualidades masculinas de los guapos y los compadritos. Además de los poemas de Celedonio Flores nos encontramos también, por ejemplo, con los de Dante A. Linyera. Se podría decir que Flores, Linyera y de la Púa fueron tres de los más importantes poetas en esta habla popular. Pues bien, al igual que El Negro Cele hacía con Villa Crespo, Linyera nos presenta el Barrio Piñeiro donde su canto «supo ser macho como un puñal» ${ }^{272}$. Como tantas veces leímos en las letras de tango vemos en este poema el barrio por cuyas aceras «lucen los machos como banderas su lengue en flor» ${ }^{273}$.

En los poemas de estos tres importantes poetas, así como de otros como Gagliardi, Yacaré, Garibaldi o Julián Centeya hallamos innumerables referencias al protagonista del relato tanguero que tanto ayudó al tango -en nuestra opinión- a llegar a todos los rincones del mundo. De nuevo nos encontramos con que la actividad de estos poetas tuvo lugar durante la Edad de Oro del tango. Cada vez estamos más cerca de poder afirmar que el relato acerca del tango originario que tiene al compadrito como protagonista se creó en esta época tan importante para el género.

En cuanto al empleo del lunfardo en las letras de tango comenzaremos recordando lo que nos dice el experto Oscar Conde:

«Más de la mitad de las letras escritas en las décadas de 1920 y 1930 contienen al menos tres o cuatro lunfardismos y en muchísimos casos alrededor de diez». ${ }^{274}$

271 Véase el listado de poemas lunfardos en el Apéndice A..

272 Dante A. Linyera, "Barrio Piñeiro», cfr. TTL, acceso el 17 de junio de 2021, https://www.todotango.com/musica/tema/1362/Barrio-Pineiro/.

273 Ibidem.

274 Oscar Conde, Lunfardo. Un estudio sobre el habla popular de los argentinos, (Buenos Aires: Taurus, 2011), 382. 
A continuación, nos presenta como ejemplo de tango lunfardo por excelencia «El ciruja» —un tango de 1926-, de Francisco Marino y Ernesto de la Cruz. La historia de esta canción se desarrolla en el arrabal y el protagonista es un hombre llamado ciruja por su habilidad con el cuchillo. Vemos en esta letra la eterna escena de dos hombres peleándose por el amor de una mujer y donde el conflicto les da pie a intentar demostrar su coraje:

«Frente a frente, dando muestras de coraje, los dos guapos se trenzaron en el bajo, y el ciruja, que era listo para el tajo, al cafiolo le cobró caro su amor. Hoy, ya libre'e la gayola y sin la mina, campaneando un cacho'e sol en la vedera, piensa un rato en el amor de su quemera y solloza en su dolor». ${ }^{275}$

En cuanto a nuestra selección de letras de tango podemos afirmar que la mayoría contiene algún término lunfardo en sus estrofas. La mayor parte de estos términos tienen que ver con dos de las categorías ideológicas que ya hemos nombrado: jactancia y tipos.

El empleo de estos términos ayuda a encuadrar las historias que narran los tangos en un tiempo y en un espacio concretos: el arrabal rioplatense en los primeros años del siglo XX. Las letras se alejan del lenguaje modernista e, incluso, del lenguaje castellano común. El empleo de un vocabulario tan concreto le dio al tango un carácter muy particular y logró que para siempre se le relacionara con los barrios orilleros de Buenos Aires o Montevideo. Definitivamente, el lunfardo aportó su granito de arena en la labor fundamental de ponerle cara y cuerpo al tango, la cara y el cuerpo del compadrito arrabalero.

${ }^{275}$ Ernesto de la Cruz y Alfredo Marino, «El ciruja», 1926, cfr. TTL, acceso el 17 de junio de 2021, https://www.todotango.com/musica/tema/601/El-ciruja/. 
Como conclusión de este capítulo dedicado a la presencia de la masculinidad en el lenguaje podemos decir que este elemento fue determinante en la consagración de un mito alrededor del tango y en el encumbramiento del compadrito como elemento central. Al plantear el recorrido historiográfico vimos cómo el primer documento que nos habla de cómo era este género rioplatense data de 1903, es un artículo de la revista Caras y Caretas y en él nos hablaban de esta música orillera y de compadritos como un fenómeno agonizante. Por tanto, no tenemos registros de cómo era el género en la segunda mitad del XIX, aunque sí sabemos que existía y que era conocido popularmente. Años más tarde comienza el recorrido literario de las figuras masculinas con Evaristo Carriego y su descripción de los arrabales que verá continuación en numerosos textos literarios posteriores. Además, hemos visto que el vocabulario lunfardo es rico en términos relacionados con los tipos que hemos descrito y, como colofón, que durante la época de mayor auge de esta música compositores relevantes emplearon todo este vocabulario en las letras que compusieron. Se encumbran figuras como el compadrito y se crea un contexto muy concreto: el suburbio. Todo este ambiente se convierte en símbolo nacional, con rasgos que le permiten tener una identidad dentro de la gran "torre de Babel" que supuso el proceso inmigratorio. Esta Edad de Oro dura hasta los años 50, donde el tango debe dejar paso a géneros globalizados como el jazz, el rock y más adelante el pop. Cuando en los años 80 los bailarines consiguen resucitar la danza del tango lo hacen incluyendo esa estética arrabalera de los años 20 y 30 . Esa manera de afrontar la danza del tango triunfa en todo el mundo y a partir de ese momento Buenos Aires es sinónimo de arrabal, compadrito, entrevero y facón.

\subsection{La masculinidad en la coreografía del tango.}

Después de analizar las letras de tango, el lunfardo, la literatura y los diferentes relatos de la historia del tango llega el momento de ver cómo ese alarde de masculinidad que encontramos en todos estos ámbitos se ve reflejado -0 no- en los diferentes estilos que actualmente se pueden distinguir en el tango danza. Para ello analizaremos, en primer lugar, el ambiente de baile que se vivía a finales del siglo XIX y principios del XX, 
cuáles eran las danzas que se bailaban en el momento histórico en el que se comienza a hablar del tango, aunque ya llevara años de existencia. Creemos imprescindible para entender su evolución saber qué novedades aportó este género a la historia de la danza. Nos interesa sobremanera dejar claro por qué el tango se distinguió de todas las danzas anteriores, incluso de aquellas que algunos estudiosos señalan como sus precedentes. Sería este el caso de la habanera, la milonga o el candombe. Hablaremos de si la aparición del tango supuso una revolución desde el punto de vista coreográfico, sobre todo, por uno de sus más importantes pilares: el abrazo. Este tema también es foco de polémica entre autores de los que ya hemos hablado: si el tango es la primera danza abrazada, si el abrazo del tango es diferente a los enlaces de otras danzas, todas estas cuestiones difíciles de resolver mientras no se presenten pruebas irrefutables como afirman tener investigadores como Marcelo Castelo, por ejemplo, al que aludiremos en más de una ocasión.

Nosotros hemos recurrido a una fuente para nosotros fiable en muchos aspectos y por varias razones. Se trata de la revista ilustrada Caras y caretas, un semanario que nació en Montevideo pero que pocos años después de su fundación se trasladó a Buenos Aires y allí estuvo en vigor entre 1898 y 1939. Su edición completa se puede consultar en la Hemeroteca Digital de la Biblioteca Nacional de España ${ }^{276}$. Nos propusimos encontrar imágenes y referencias al modo como se bailaba el tango en los primeros años y por ello revisamos ochocientos cincuenta números publicados entre 1898 y 1915. Nuestros objetivos eran dos. Por un lado, intentar averiguar en qué medida la danza en general estaba presente en una publicación de gran relevancia en su época y qué papel se le daba al tango en concreto. Por otro lado, y teniendo en cuenta que estábamos ante una revista que daba mucha importancia a las imágenes, observamos la gran cantidad de fotografías, caricaturas, anuncios publicitarios y otras ilustraciones que podían aclararnos cómo se bailaba el tango en cada momento.

Las razones por las que nos parece fiable este medio de comunicación son fundamentalmente dos: fue el semanario más importante de su época y

${ }^{276}$ Véase nota 29 de este trabajo. 
supuso un fiel reflejo de los grandes acontecimientos sociales del momento, al menos de una parte de la sociedad.

Una vez aclarado lo concerniente al género rioplatense en cuanto al modo de interpretarse en épocas pasadas, analizaremos los diferentes estilos de tango que existen actualmente y veremos en cuáles de ellos podemos apreciar esa exacerbada masculinidad de la que hemos hablado desde el comienzo de este trabajo.

3.3.1. Las danzas que ya existían a finales del siglo XIX y principios del siglo $X X$.

Como ya hemos repetido en varias ocasiones, el tango surge en la segunda mitad del siglo XIX. Años más tarde, según cuentan las crónicas, se presenta como algo absolutamente original, muy distinto a todo lo que ya existía. Es evidente que una danza no nace de la nada y que muchos elementos que apreciamos en el tango tienen que ver con las danzas ya conocidas, pero este género adquirió una personalidad propia que, en nuestra opinión, facilitó que se convirtiera en protagonista de una gran leyenda durante décadas.

Antes de abordar los cinco estilos de tango, nos parece interesante hacer referencia a las danzas que existían cuando el tango apareció en el Río de la Plata. Dado que la fecha exacta es desconocida hablaremos de la segunda mitad del siglo XIX y buscaremos cómo se bailaba entonces para destacar lo original del género y para analizar en la medida de lo posible la figura del hombre en ellas. El Chúcaro parte del malambo en su propuesta, pero existían muchas más danzas en boga: el candombe, el carnavalito, el chamamé, el cielito, el ecuador, el escondido, el gato, el loncomeo, el pericón, el remedio, el triunfo, la arunguita, la calandria, la cueca, la huella, la mediacaña, la patria, la zamba, la chacarera o el cuando. Todas ellas de coreografía en grupo o pareja suelta. Algunas de estas danzas servían como cortejo, aunque la mayoría eran danzas de celebración colectiva, por eso el contacto entre los bailarines no era esencial.

Somos conscientes de que las danzas folclóricas no tienen que ver en principio con el tango y su coreografía, pero las traemos aquí porque nos 
interesa establecer la conexión que planteábamos al principio de nuestro trabajo entre el gaucho y el compadraje. Lo masculino o la hombría - tal y como se entendía entonces- exhibida en algunas de esas danzas pudieron determinar la imagen de esa sociedad orillera surgida $-\mathrm{y}$ en gran medida mitificada- como fruto de la inmigración y la urbanización de Buenos Aires y Montevideo.

Por otro lado, además de las danzas propias del folclore, asistimos en esa época al auge de las danzas importadas de Europa como el vals, la polca y la mazurca, de las que también hablaremos.

Francisco Canaro en sus memorias nos habla del vals "La loca de amor» como un tema muy en boga y habla también de su primer repertorio con un violín hecho con una caja de aceite:

«Tras largas horas diarias de estudio y ensayo, aprendí varias piezas, haciéndome un repertorio de tangos, valses, polcas, mazurcas, skatings y lanceros. En esos tiempos se bailaba mucho los lanceros, especie de cuadrilla con varias parejas que forman figuras cambiando de lugar». ${ }^{277}$

Vemos, por tanto, que existían danzas populares y danzas palaciegas. Sobre el intercambio de danzas entre los diferentes estratos sociales nos dice Carlos Vega:

«Por regla general, las danzas aborígenes y las danzas africanas puras no ascendieron a los estrados palaciegos; las danzas europeas de palacio, en cambio, descendieron a todos los grupos sociales medios y aun a los propicios centros indios y negros». ${ }^{278}$

Carlos Vega alude en su libro Las danzas populares argentinas a la clasificación aportada por Curt Sachs en 1933. Una de las ideas de Sachs que nos transmite Vega nos interesa mucho porque se trata de la clasificación en dos grupos que denomina "convulsión-abstracción-introversión" y "conciencia-

${ }^{277}$ Francisco Canaro, Mis bodas de oro con el tango. 1906-1956 (Buenos Aires: CESA Talleres gráficos S.R.L), 40.

${ }^{278}$ Carlos Vega, Las danzas populares argentinas (Buenos Aires: Instituto Nacional de Musicología Carlos Vega, 1986), 28. 
mímica-extraversión". La primera describiría las danzas de un matriarcado y la segunda las de un patriarcado. ${ }^{279} \mathrm{En}$ las palabras con las que se describen aquí las danzas patriarcales reconocemos los rasgos que se le aplicaban a los hombres de los que tanto hemos hablado: control —más bien contenciónde sentimientos, conciencia, importancia de los gestos y, en general, de su imagen -mímica- y tendencia al exhibicionismo, en este caso, a través del baile —extraversión-. Acerca de este último concepto nos dice Magali Saikin:

«El hombre tiene una función extrovertida, su estética es demostrativa: "aquí está la elegancia", necesita un público observador a quien él muestra con agrado su acicalado cuerpo y sus virtudes de bailarín (porte, pinta, silueta, clase). En otras palabras, el objetivo del hombre al bailar es enteramente narcisista. Este mostrarse es de primordial importancia. La jactancia masculina se traduce en la conducción y dominación de la hembra "con voluntad omnímoda, sin galantería, como instrumento dócil de su potestad y de su fantasía, para descollar y 'florearse' él». ${ }^{280}$

Vemos aquí relacionados varios aspectos de los que ya hemos hablado pero que conviene poner en relación. La jactancia, de la que hablamos al tratar el lunfardo por ser categoría de vocablos relacionados con el hombre, la emplea Saikin para hablar de cómo el bailarín — para nosotros, especialmente, el compadrito- emplea a la mujer en el tango para adornar su baile elegante y, así, exhibirse él ante el público. El alarde de masculinidad es, repetimos, ineludible.

Continuando con el análisis de las danzas vemos que en la clasificación de Sachs se recogen un total de sesenta y tres que se desarrollan en pareja, de las que solamente tres son bailadas por parejas abrazadas: el tango, la milonga y los modernos 281 .

El tango nace como danza y como tal ofrece una novedad importante en sí misma: el estrecho contacto que supone su abrazo. Existían danzas

\footnotetext{
279 Ibidem, 38.

${ }^{280}$ Magali Saikin. Tango y género. Identidades y roles sexuales en el Tango Argentino (Stuttgart: Editorial Abrazos, 2004), 28.

281 Ibidem, 43.
} 
como el vals, que se bailaban en pareja, pero no existía el concepto de abrazo, que condiciona toda la coreografía puesto que establece el eje de la pareja y le da un carácter social absolutamente novedoso.

En este subcapítulo nos interesa analizar tres elementos: el malambo y todas aquellas danzas individuales o colectivas relacionadas con el gaucho, las danzas de pareja — sobre todo observar cómo se comportaba la pareja y cuál era su carácter para compararlo con el tango-y el papel del hombre en estas. Para realizar este análisis haremos referencia a los trabajos de Sachs y Vega, nos remitiremos a las teorías de los investigadores que nos preceden $y$, además, aportaremos nuestras propias conclusiones extraídas de la revisión del semanal bonaerense Caras y Caretas. Hemos creído fundamental realizar una búsqueda de imágenes que reflejen cómo bailaba la población tanto en romerías populares como en grandes salones. Como ya hemos dicho, este exhaustivo recorrido nos ha ayudado a entender un poco más cómo se bailaba y, lo que para nosotros es más importante, cómo se hablaba de él en un medio de comunicación.

Sobre el malambo dice Carlos Vega:

«Danza varonil y recia, el Malambo fué (sic) en la campaña argentina prueba de vigor y destreza durante todo el siglo pasado. Celebrado en fiestas, fogones y pulperías, animó las horas de esparcimiento o de descanso con el gustoso "trabajo" de su difícil realización, y dio provisional prestigio a los más hábiles y esforzados.» ${ }^{282}$

De nuevo vemos relacionada la virilidad con la fuerza y la habilidad y, lo que es más importante, la danza como medio de exhibición de destrezas masculinas. De hecho, nos dice Carlos Vega que el malambo que predominó en Argentina era una especie de competición entre dos hombres a través del zapateo que tiene como punto de partida el deseo de compararse con los demás. Esto nos recuerda a la anécdota ya comentada que contaba el Chúcaro en la que un compañero del colegio y él se medían la guapeza ${ }^{283}$.

282 Ibidem, 51.

${ }^{283}$ León Benarós, «La vida del Chúcaro contada por él mismo. En diálogos con León Benarós», Folclore, 89 (1965): 7. 
Esta actitud la vemos claramente representada en el compadrito cuando, según cuenta principalmente el relato clásico, emplea el tango de los comienzos para exhibir sus capacidades, sus conquistas y, cómo no, su masculinidad. Además, parece que existió en el siglo XIX un malambo que añadía un elemento que también veíamos en los prototipos masculinos de ese siglo: el cuchillo. Ya hemos apuntado con anterioridad que el facón es un símbolo de hombría y un elemento heredado del hombre del campo. He aquí otro elemento que formaría parte de la continuidad que El Chúcaro intenta demostrar entre el gaucho y el compadrito. Recordemos que en su cuadro coreográfico el facón es un símbolo, es lo único que el gaucho conserva al cambiarse la ropa y convertirse en compadrito.

Existía también una variante -más minoritaria- de pareja suelta de hombre y mujer. No nos detenemos en ella por no haber gozado de gran relevancia en su momento.

En una entrevista publicada por el Ministerio de Cultura a Silvia Zerbini, uno de los referentes de danza folclórica en Argentina y quien fue, también, directora del Ballet Folclórico Nacional, habla del malambo como «una danza viril por excelencia». ${ }^{284}$

En la descripción que del malambo hace Carlos Vega encontramos otro elemento en común entre el gaucho y el compadrito. Más que un elemento se trata de un rasgo de carácter. Dice Vega:

«Es danza ruda pero sobria. De ningún modo pueden aceptarse, sin alterar su estilo, los saltos violentos, las contorsiones desgobernadas y los movimientos acrobáticos. La mesura es característica tradicional en la Argentina». ${ }^{285}$

En estas tres líneas se ve resumido el carácter del gaucho, templado pero firme, sin grandes aspavientos, pero con la energía y la fuerza suficiente

284 «¿Cuáles son las danzas típicas de la Argentina?», Ministerio de Cultura Argentina, acceso el 17 de febrero de 2021, https://www.cultura.gob.ar/que-conocemosacerca-de-nuestras-danzas-8433/.

${ }^{285}$ Carlos Vega, Las danzas populares argentinas, (Buenos Aires: Instituto Nacional de Musicología Carlos Vega, 1986), 76. 
para reaccionar ante los imprevistos. Esta mesura de la que nos habla la heredarán -según nosotros consideramos la continuidad social entre el gaucho y el compadrito- el guapo en primer lugar —así lo vemos reflejado, por ejemplo, en la película Un guapo del 900 de la que ya hemos hablado$y$, posteriormente, irá mermando en los demás prototipos masculinos, desde el compadre hasta el malevo pasando por nuestro protagonista, el compadrito. En este, al contrario que en los anteriores, la jactancia y la exageración serán seña de identidad.

El carnavalito también es una danza muy antigua que se da sobre todo en la zona de Jujuy y Salta. En esta danza hombres y mujeres se encuentran, se separan, pero no representa el encuentro de una pareja, sino una danza de celebración colectiva.

El cielito, el pericón y la media caña son danzas clasificadas como "de pareja suelta interdependiente" por Carlos Vega, lo que significa que hombre y mujer bailan principalmente sueltos, pero en ocasiones se encuentran para realizar movimientos en coordinación con otras parejas: líneas, rondas, etc.

Existen otras danzas también de pareja suelta pero independiente. En estas coreografías las parejas, cuando se encuentran, bailan sin coordinarse con las otras parejas. Son el cuando, la sajuriana, la condición y el montonero o federal. Todas estas danzas nobles son semejantes al minué o a la gavota con aires más ceremoniosos. Al hablar del montonero Vega llama la atención sobre la relación entre las coreografías y los acontecimientos políticos y sociales del lugar donde surge una danza. En el caso del federal nos cuenta que, entre otras cosas, la coreografía de esta danza está relacionada con las hazañas militares de los gauchos:

«Allá por el año 1818 empieza a llamar la atención de los militares una original táctica concebida en las llanuras de acuerdo con las aptitudes de los gauchos, con las características del territorio, con la extensión del escenario y con el género y cantidad de los recursos disponibles. Era su fundamento, en cuanto exigía a los combatientes esfuerzos y valor ilimitados, la subordinación fanática del hombre a su caudillo. Estas tropas campesinas se llamaron al 
principio "federales" o "anarquistas", y poco después recibieron el nombre de "montonera" —como es sabido—». ${ }^{286}$

Ese sería el supuesto origen de una danza que llegaría a formar parte de comedias y obras de teatro ya en los años treinta del siglo XIX.

Además de estas danzas se popularizó el vals, que en esta zona rioplatense se llamará vals criollo. Se puede ver en esta famosísima danza un paso adelante en el encuentro de la pareja. Las danzas folclóricas eran mayoritariamente colectivas y las que requerían emparejamiento no permitían que las parejas perdieran el contacto y la coordinación con el gran grupo. En el vals un hombre y una mujer se encuentran y bailan juntos, pero no se abrazan. El abrazo llegará con el tango, este es el principal aporte que lo hace absolutamente original. El profesor Gustavo Varela habla en su Tesis Doctoral de que una de las razones por las que el abrazo surge en este momento y no en otro tiene que ver con el hecho de que en esta época empieza a hablarse de sexualidad. Independientemente de que el tango surgiera o no en los prostíbulos, lo que sí es cierto es que la actividad prostibularia estaba en auge a comienzos del siglo XX y, como nos dice Varela, en Buenos Aires se crearon durante esos años gran cantidad de casas de citas y otros lugares semejantes:

«Hay más industrias, más obras públicas, el mercado está en continua expansión; pero a la vez hay marginación, pobreza, enfermedad, delincuencia. $Y$ prostitución: las calles de Buenos Aires se inundan de yirantas, proxenetas, cafishos, prostitutas e invertidos y una verdadera industria del sexo se instala en casas de tolerancia, casas de citas, caféconcert, bares, habitaciones, "lugares de diversión o de la buena vida"». ${ }^{287}$

También se ha hablado de que el abrazo fue una herramienta que el hombre empleó para dirigir la danza y que le ayudó a hacer alarde de su pinta y sus condiciones de varón. De hecho, el abrazo es el principal elemento que

${ }^{286}$ Carlos Vega, Las danzas populares argentinas (Buenos Aires: Instituto nacional de Musicología Carlos Vega, 1986), 375.

${ }^{287}$ Gustavo Varela, «Regularidades y rupturas: un análisis genealógico de la historia del tango argentino (1880-1968)» (tesis doctoral, Universidad de Buenos Aires, 2014), 62. 
define qué bailarín toma el rol del hombre y cuál el de la mujer. La mano derecha en la cintura de la pareja nos informa de que ese será el bailarín que dirige. Actualmente existen parejas de dos hombres o dos mujeres que bailan tango, pero en las épocas a las que nos referimos en este estudio de esa función se encargaba, siempre, el hombre. La novedad de los últimos años es el hecho de que la pareja no tenga que estar formada, obligatoriamente, por un hombre y una mujer. Pues bien, cuando el tango surgió, la gran novedad pudo haber sido que la pareja hombre-mujer que interpretaba la danza debían estar, simplemente, abrazados.

El abrazo, desde la perspectiva que se mire, es una muestra de afecto y requiere de un acercamiento de la pareja. Esto, indiscutiblemente, tiene que estar relacionado con un deseo social de que los hombres y las mujeres se acerquen 0 , al menos, con una concesión tácita para que así sea. La danza abrazada es representativa, en nuestra opinión, de esa subjetividad que se estaba fraguando en la sociedad acerca de la sexualidad, de lo que nos habla Varela. De nuevo aludimos a su acertado enfoque que junto al de Matamoro nos permite relacionar las distintas etapas del género tango con los cambios políticos y sociales del mundo que lo vio nacer. Es imprescindible entender los comportamientos sociales para poder comprender los cambios que se producen en manifestaciones populares como lo es una danza.

Hasta aquí lo que extraemos de los estudios de Vega y Sachs, así como del enfoque de Gustavo Varela y Blas Matamoro. Veamos ahora qué nos cuentan las imágenes de Caras y Caretas sobre lo que ocurrió con respecto al tango y otras danzas desde 1898 y, por referencias en algunos artículos, también de años anteriores. Recordamos que hemos revisado todos los números editados de este semanario entre los años 1898 y 1915.

Caras y Caretas era un medio de comunicación de carácter satírico en el que se plasmaba la realidad política y social tanto de Argentina como de países extranjeros. Hemos leído noticias de los conflictos bélicos más relevantes de cada época en cualquier parte del mundo, de catástrofes naturales, sucesos, actualidad política y, sobre todo, de la actualidad porteña y de las provincias de Buenos Aires. Dentro de la crónica social argentina tienen gran relevancia las celebraciones principalmente en grandes salones 
en los que, frecuentemente, se bailaba. El primer número en el que aparece un artículo sobre la danza data de 1898 y habla de la importancia de los bailes de beneficencia y de lo fundamental que es bailar no para disfrute de los bailarines, sino para ayudar a los pobres:

«No ha de moverse las piernas, ni juntarse los cuerpos, ni poner mano de varón en cintura de inocente niña descotada, ni profanar púdicos descubiertos contornos con ojos de sátiro, ni proferir palabras atrevidas en oídos castos, sino en, con, por, si, sobre los pobres y con intención de practicar la caridad, antes triste, silenciosa, lagrimosa y doliente, y hoy alegre, resplandeciente, musical y bailable.» ${ }^{288}$

Parece que el vals era una danza considerada apropiada para salvaguardar el recato de varones y damas solidarios. Este artículo inaugura una gran serie de referencias a danzas palaciegas procedentes de Europa. Entre mazurcas, minués, polcas, polonesas, tarantelas, y otras danzas de corte destaca en los primeros años del siglo XX uno por encima de todos: el boston. En 1901 se habla de este como el baile moderno ${ }^{289}$ se afirma que su influencia acoge el resto de danzas:

«Todos los demás han desaparecido o se han refundido en él; ahora se «bostonea» la polka, la mazurka, y hasta la cuadrilla. $Y$ ya no se trata del vals de otras épocas, tieso, rápido, sacudido, de tiempos bien marcados y pasos netos: el que bailaba así se sofocaba pronto y apenas podía conversar; ahora se conversa al son de una música suave que no obliga a brincar ni a agitarse.» ${ }^{290}$

Parece que esta danza simplemente aporta otra manera de bailar el vals. En 1902 podemos leer en una página dedicada a cómo colocar las manos en el boston cuál es el rol que deben seguir hombre y mujer en esta danza:

\footnotetext{
288 «Bailemos un poco», Caras y Caretas, 8 (1898):13.

290 «El Boston», Caras y Caretas, 155 (1901): 62.
} 
«La señora ó(sic) señorita debe ser como un juguete perfumado en los brazos del caballero: él solo es el dueño y dirige los movimientos: ella no es más que la sierva dócil y linda». ${ }^{291}$

El carácter protector y paternalista del hombre determina, como vemos, la manera de afrontar esta danza. Se determina la posición de las manos, pero es incoherente pensar que la actitud general del bailarín no mostrara también una exagerada masculinidad. De la relevancia de esta danza en los primeros años del siglo XX da fe la alusión en un número de 1906 titulado Lo que se bailará el próximo invierno ${ }^{292}$ a la polémica entre dos escuelas, una antigua y otra moderna. La primera sería partidaria del vals y los que se adhirieran a la segunda defenderían el boston como danza que debería estar en boga en posteriores temporadas. Sin embargo, no volvemos a leer ninguna alusión a este baile desde un número de 1904 en el que nombra el Boston-ball, una mezcla entre juego y baile que está de moda en ese momento en París, por lo que podemos deducir que el vals, del que sí tenemos noticia en números posteriores, fue el gran triunfador de aquellas temporadas.

Otras dos danzas se nombran entre 1901 y 1902 como novedosas en Buenos Aires: la serpentina y el skating. La primera era, según leemos en la publicación, la danza preferida en Alemania por esos años y de la segunda no se dan detalles de su ejecución o su procedencia, aunque lo podemos relacionar con el éxito posterior del patinaje como actividad artística.

Además de los bailes en grandes salones encontramos en Caras y Caretas referencias a las fiestas o romerías - se nombran de una manera o de otra, aunque predomina el término romerías- españolas. En estos eventos destacan las danzas típicas de diversas regiones del país como la muiñeira o la jota aragonesa. Recordemos que al hablar en el Estado de la Cuestión sobre el origen del tango vimos cómo uno de los primeros lugares en los que supuestamente se bailaba eran estas romerías. De allí habrían pasado al conventillo, según el relato clásico de lo sucedido. También había

\footnotetext{
291 «La posición de las manos en el baile», Caras y Caretas, 188 (1902): 55.

292 «Lo que se bailará el próximo invierno», Caras y Caretas, 379 (1906): 74.
} 
bailes tradicionales de otros países como Alemania, Francia, Irlanda o Suiza, aunque su proyección en este semanario es menor.

Por último, debemos hacer alusión a los bailes tradicionales argentinos, que también ocupan un lugar en el noticiario al que nos estamos refiriendo, aunque de menor relevancia que los bailes de salón. Nos referimos al pericón, el gato, la vidalita y otros aires que se nombran a partir de 1904 y que están más relacionados con el campo que con la vida urbana. Encontramos un párrafo muy esclarecedor al respecto en un relato que describe una escena campestre - ficticia, suponemos-en octubre de 1905:

«Todos nuestros bailes parecen describir pasiones y calladas escenas. El gato persigue a la perdiz temblorosa, la chacarera se alegra al hallar a su amado en las montañas, el Pericón es la historia de un triunfo de amor en la vida serena de los llanos y de los montes». ${ }^{293}$

Debemos hacer referencia aquí a lo que Carlos Vega nos decía sobre el hecho de que las danzas palaciegas también habían sido asimiladas por el pueblo llano, ya que en este relato al que nos hemos referido también se incluye el vals como música que suena y se baila en el encuentro en el campo.

Entre 1898 y 1912 no encontramos más que esta imagen campestre y las referencias a las danzas folclóricas son escasas, solo algunas partituras de gatos, un cielito y un tema criollo. Las alusiones a la música y a la vida del campo se ven materializadas en poemas alusivos a la guitarra o a la vida en la pampa y poco más. En estas pocas ocasiones se habla de los gauchos y los payadores reproduciendo alguna escena gráficamente. Deducimos de esta escasez de información sobre la vida en el campo que la intención de este medio de comunicación era dar cuenta de la vida en la ciudad y fundamentalmente del centro, ya que también son minoría los artículos que hablan de las orillas de la ciudad.

${ }^{293}$ «El pericón», Caras y Caretas, 366 (1905): 73. 


\subsubsection{La masculinidad en los diferentes estilos de tango.}

Antes de abordar el tema —crucial en nuestro estudio- de los estilos de tango conviene que revisemos el concepto de estilo. Debemos aclarar que de lo que hablamos es de la repetición de ciertos patrones a la hora de afrontar la puesta en escena de un tango. Desde los comienzos de la historia del tango existieron diferentes maneras de bailarlo. En un tiempo se diferenciaban por barrios o por provincias, por lo que no podemos afirmar que los cinco estilos de tango de los que hablaremos representan las únicas cinco maneras de bailar el tango rioplatense.

Uno de los musicólogos que más han reflexionado sobre la noción de estilo musical fue Leonard $\mathrm{B}$. Meyer y recogemos una de esas reflexiones que nos parece que se acerca mucho a lo que nosotros entendemos por estilo cuando hablamos del género tango:

«(...) estilo es una réplica de patrones, ya sea en la conducta humana o en los artefactos producidos por la conducta humana, que resulta de una serie de elecciones tomadas dentro de un conjunto de restricciones». ${ }^{294}$

Generalmente los diferentes estilos de tango están ligados a los rasgos de la música que quieren representar, pero nosotros quisiéramos aportar un elemento más: la intención. ¿Qué quiere mostrar una pareja de bailarines al escoger tal o cual gesto? No hablamos de los pasos, si son más o menos acrobáticos, si hay más o menos balanceos, boleos u ochos adelante o atrás. Ponemos nuestro foco en la mirada, la postura y los gestos de los bailarines, especialmente en la parte masculina de la pareja.

Nuestro trabajo sostiene y defiende que la coreografía del tango que se baila actualmente se fue creando influida en gran medida por los personajes masculinos de la época que lo vio nacer y por la historia que se construyó con ellos como protagonistas. En páginas anteriores de este trabajo veíamos cómo José Sebastián Tallón nos hablaba del modo de caminar de los

${ }^{294}$ Citado en Favio Shifres, Alegandro Pereira Ghiena, Romina Herrera y Mariana Bordoni, «Estilo de ejecución musical y de danza en el tango: atributos, competencia y experiencia dinámica», Cuadernos de Música, Artes Visuales y Artes escénicas, vol. 7, n² (2012):86, acceso el 23 de abril de 2021, http://cuadernosmusicayartes.javeriana.edu.co. 
compadritos, su gesto amariconado y esos modos que le dieron al tango un estilo propio de exageraciones eróticas. Nosotros, como a estas alturas es ya sabido, creemos que el modo exageradamente viril —o la intención de serloque observamos en las imágenes, reales o no, de muchos hombres del siglo XIX y de principios del siglo $X X$ especialmente en ambientes públicos, se ve reflejado en la danza tango. Pero también es cierto, como veremos a continuación, que no es así en todos los estilos de este género. Además, afirmamos, y esta es la idea fundamental que defendemos en nuestro trabajo, que la manera en la que se habló de estos personajes fue determinante a la hora de conformar la actitud de los bailarines de tango, especialmente del hombre.

Por esa razón es imprescindible incluir en este trabajo el análisis de todos ellos. La exhibición de lo masculino no es la misma en unos que en otros. Tampoco podemos incluir a todos los estilos en ese camino de mitificación que comenzó antes de que tuviéramos noticias de él y llegó a la actualidad. Esto quiere decir que no todos los estilos de tango fueron incluidos en esa historia altamente mitificada que se construyó y con la que se consiguió que el género se hiciera universal. Básicamente esta leyenda se fraguó con uno de estos estilos como eje: el tango de salón. Veremos cómo se crea un estilo académico que representa una versión más aséptica del género, nada que ver con el tango canyengue que algunos sitúan en los primeros años y que se popularizó en los 80 y poco con el tango milonguero. Por último, es importante saber por qué sucede, qué se pretendía con ello y cómo es recibido por las diferentes generaciones de bailarines. ¿Hubo algún ingrediente más que ayudó a la creación de este estilo? Lo veremos más adelante.

Antes de continuar con el análisis de los estilos presentamos un mapa conceptual con los rasgos básicos de cada estilo para dejar claras las diferencias básicas entre uno y otro. De esta manera será más fácil, según nuestro criterio, afrontar la descripción pormenorizada de cada uno de ellos así como las relaciones que se establecen entre unos y otros. 


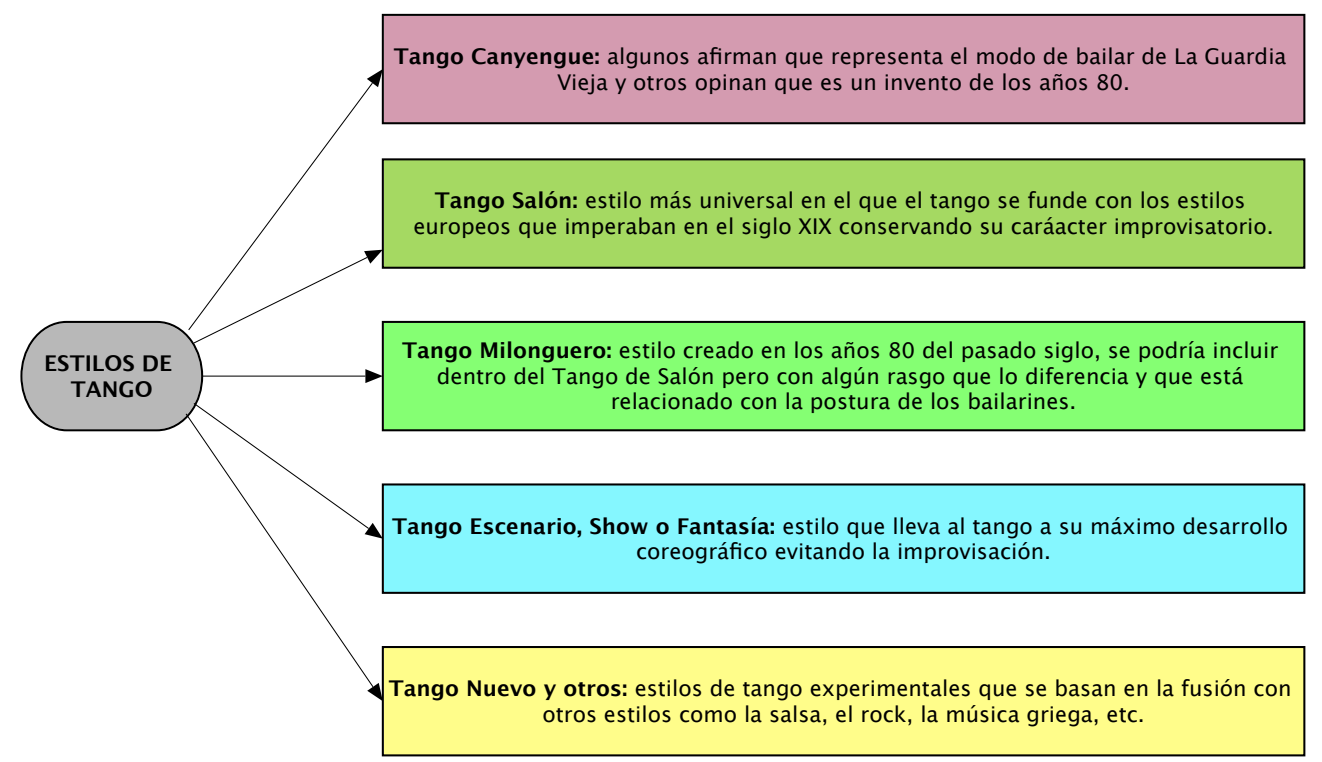

Figura 4. Esquema de los cinco estilos más reconocidos de tango.

Es posible que en lugar de hablar de estilos de tango en cuanto a coreografía se refiere deberíamos hablar de diferencias en la música del tango. Las diferencias rítmicas y melódicas entre los distintos estilos musicales condicionan los pasos, el abrazo, la caminada y el resto de elementos que definen la coreografía tanguera. Esto sucede, al menos, en cuatro de los estilos que vamos a analizar. Pero antes de hablar de las danzas detengámonos un momento para aclarar cuáles eran y cuándo se establecieron las diferentes maneras de interpretar instrumentalmente el tango.

En 1910 nacen las agrupaciones de tango más estables que se conocen con el nombre de orquestas típicas y cuya evolución es determinante para la evolución de la danza. En los comienzos estaban constituidas por bandoneón, flauta, violín y guitarra y una década más tarde se convierten en sextetos incluyendo bandoneón, piano, violín y contrabajo. Estos sextetos crecerán y pronto llegarán a alcanzar los diez integrantes. Poco a poco se van agregando cantores, aunque estos no adquirirán verdadera importancia hasta los años treinta del pasado siglo. $Y$ es este momento, al igual que nos sucedía al hablar de las letras, el que nos interesa. En esta época, conocida como La década infame por diferentes sucesos que tuvieron que ver con fraudes 
políticos o con dramas sociales como el gran número de suicidios, se establecen cuatro estilos de tango en lo que a las orquestas se refiere. Recordamos que entramos en la Edad de Oro del tango. Estos cuatro estilos serían el tradicionalista, el decareano, otro más estilizado y el de renovación que representará la vanguardia. Estas diferentes maneras de interpretar la música rioplatense van a determinar los diversos modos de afrontar su representación en la pista.

Salvo el tango de salón del que se hablaba ya en la segunda década del siglo $X X$, no tenemos noticias de que existieran tradicionalmente otros estilos de danza en el tango. Por lo tanto, debemos basarnos en la información audiovisual que nos muestra cómo se baila actualmente, y para ello hemos optado por describir los patrones que se repiten en los vídeos de bailarines representativos de cada uno de los estilos de los que hablamos. El análisis de estas fuentes primarias, junto con los testimonios de profesores e investigadores, nos ayudará a diferenciar todo lo relacionado con cada uno de los estilos y a entender en qué momento fueron surgiendo. Además, presentaremos las conclusiones que extraemos de observar las ilustraciones de la revista Caras y Caretas para intentar dilucidar si lo que nos cuentan estos profesores en relación con alguno de estos estilos puede tener sentido.

En general, lo que comúnmente se conoce del desarrollo del tango en cuanto a danza es que es interpretado por un hombre y una mujer y que estos adquieren roles diferentes: el del hombre que es el que lleva y el de la mujer que es la que debe dejarse llevar. Para nosotros, además, durante mucho tiempo y en etapas no siempre continuas en su historia, el tango sirvió como medio de exhibición al hombre de sus cualidades, tanto como bailarín como en su calidad de hombre. Por eso, estamos de acuerdo con Magali Saikin cuando nos hablaba, según mostrábamos en páginas anteriores, de la función de extroversión que ejerce el hombre en la pista de baile. ${ }^{295}$

Actualmente, como muestra de la evolución que ha sufrido el tango fruto de las influencias de la ideología feminista y la tendencia a un carácter

295 Véase nota al pie 232 de este trabajo. 
más igualitario de la sociedad, estos roles son definidos como leader y follower, para evitar los términos rol masculino y rol femenino. De esta manera se establece que no necesariamente el que lleva debe de ser el hombre y viceversa. También en este sentido fue pionero el Tango queer, que nació para contravenir las normas de género por las que se regían todas las milongas hasta el 2000, año en que se celebró el primer festival internacional de esta modalidad de tango en Hamburgo, Alemania. ${ }^{296}$ No incluimos este tipo de tango en nuestro análisis de los diferentes estilos porque consideramos que lo que los define no es una manera distinta de bailar, sino un modo diferente de afrontar la danza tango como hecho social. Su importancia radica en subvertir las estrictas normas por las que el hombre dirige y la mujer sigue sus pasos. La mujer no tiene por qué esperar a que un hombre la saque a bailar, los hombres no siempre llevan y, sobre todo, las parejas no tienen que estar formadas, exclusivamente, por un hombre y una mujer. A pesar de haber supuesto una interesantísima revolución y un cambio radical en la manera de afrontar el tango socialmente, la danza sigue siendo la misma, en nuestra opinión la puesta en escena es exactamente igual ya sea interpretada por dos hombres, dos mujeres o una pareja mixta.

Hablaremos pues a continuación de los cinco estilos de tango en los que las diferencias tienen que ver con la postura corporal, el vestuario empleado y, sobre todo, la presencia de lo masculino que se aprecia en cada performance.

\subsubsection{Tango canyengue.}

El tango canyengue es protagonista de una de las múltiples polémicas alrededor de este género musical, algunas de las cuales ya han sido comentadas. Dicen muchos de quienes lo practican, como la profesora y bailarina Laura Collavini en una entrevista a la emisora de radio de la

296 El término queer significa en inglés 'raro' o 'extraño' y aplicado al tango define un nuevo modo de entender el género rioplatense que surge en los años noventa del pasado siglo. En el tango queer se diluyen los roles de género y los bailarines escogen si serán leaders o followers dentro de parejas compuestas por hombre-mujer, hombre-hombre o mujer-mujer. 
Universidad de Salamanca ${ }^{297}$ que fue el tango de la Guardia Vieja, el que se bailó entre 1880 y la década del 20. Es decir, que es el tango primigenio y pertenece por tanto a la época en la que se gestó el tango. Debía ser esta primera etapa, en nuestra opinión, la época en la que el género gozara de mayor naturalidad. Aún no tenían que explicar qué era el tango, sólo disfrutar de él. El bailarín más importante de aquella época del que nos habla Francisco Canaro en sus memorias y que podemos ver en la primera película sonora argentina, Tango, fue El Cachafaz.

Una de las grandes controversias que a veces nos encontramos al investigar el tango tiene que ver precisamente con la época del canyengue y, por eso, nos parece relevante traerla a estos párrafos. Se trata del tango bailado entre hombres. Veamos lo que nos han contado sobre el tema y lo que afirmamos nosotros después de realizada nuestra investigación.

Durante mucho tiempo - y todavía actualmente- muchos defienden que en sus orígenes el tango era bailado únicamente por hombres. Esta aseveración se basa en algunos documentos gráficos y textuales que aluden a ese hecho. Estos son, por ejemplo, las imágenes que aparecen en los artículos de Caras y Caretas que ya hemos mencionado en las que podemos ver grupos de hombres emparejados en posición de baile. Además, el poeta Evaristo Carriego, del que ya hemos hablado en el capítulo dedicado a la literatura, nos dice en su poema El alma del suburbio que «al compás de un tango, que es /La Morocha,/lucen ágiles cortes dos orilleros». 298 Otro poema nos describe un tango entre hombres:

\author{
«A bailar el contrapunto \\ se trenzaron allí al rato \\ El Tuerto y Pancracio el ñato, \\ así, que cambió el asunto. \\ Todos los dejamos solos, \\ ¡caramba!que se lucieron a allí, che 'Pardo', estuvieron
}

\footnotetext{
${ }^{297}$ Laura Collavini, entrevista por Laura Alonso, Alevare, Radiousal, podcast, 27 de febrero de 2021, acceso, http://radio.usal.es/programa/alevare/.

${ }^{298}$ Evaristo Carriego, «El alma del suburbio», Caras y Caretas, 473 (1907): 49.
} 
cuerpiando como chingolos.» ${ }^{299}$

En un tango de Ángel Villoldo, el más importante compositor de los inicios, podemos leer:

«Aquí tienen el criollo más criollo,

el que hasta aura ha encontrado rival

el chinito más pierna y compadre

que ha pisado por la capital.

Si hay un turro que sepa hamacarse

que se venga lo voy a esperar

para hacer una cuantas quebradas

de este lindo tanguito al compás.

Así podremos ver cuál es más taura,

a la voz de aura,

para bailar.» ${ }^{300}$

En este tango de la Guardia Vieja podemos ver, no solo la proposición de un hombre a otro para bailar, sino el empleo del baile para demostrar cuál es más valiente y jactarse de sus cualidades. Volvemos a ver una relación con el malambo, que también era empleado para medirse en cuanto a bravura. Así nos lo presenta Magali Saikin, pero en realidad, si leemos la letra completa, nada nos asegura que la propuesta es para bailar como pareja y no para medirse en la pista cada uno bailando con una mujer. De nuevo vemos que pueden existir dudas en muchos aspectos alrededor de este género, pero lo más evidente es que los hombres empleaban el tango para lucirse $\mathrm{y}$, de paso, demostrar quién era más hombre.

También Blas Matamoro en La ciudad del tango alude a este hecho remitiéndonos a un artículo de la revista Caras y Caretas de febrero de 1903 al que nosotros hemos accedido, en el que aparece un bailarín fotografiado

${ }^{299}$ Florencio Iriarte, «Batifondo a la villa de Roi», La historia del tango (Buenos Aires: Ediciones Corregidor, 1976), 45.

300 Ángel Villoldo, «El criollo más criollo», Magali Saikin, Tango y Género. Identidades y roles sexuales en el tango argentino (Stuttgart: Abrazos, 2004), 94. 
bailando con hombres realizando pasos de tango. ${ }^{301}$ En definitiva, es innegable el hecho en sí, lo que no está tan claro —y ese es el foco principal de la polémica- es la razón por la que esos hombres no bailaban con mujeres. Se suele argumentar que bailaban entre ellos para practicar los pasos y más tarde lucirse ante alguna mujer en una milonga. También aluden los investigadores al hecho de que la sociedad en aquel momento era eminentemente masculina así que no era tan fácil, en cualquier momento, poder conseguir que una mujer se acercara a bailar. Otra razón que se arguye es la consideración del tango como música prohibida por el hecho de que el hombre y la mujer debían acercarse mucho en su abrazo para interpretarlo y por esa razón no muchas mujeres accedían a bailar con hombres. E componente homosexual lo descartamos por no haber documentos que lo sustenten, por lo que tampoco ha dado lugar a una teoría sólida.

Nosotros hemos llegado a la conclusión de que el motivo por el que algunos hombres bailaban entre ellos es más simple y tiene que ver con que no había ningún problema en hacerlo y en situaciones en las que no había mujeres cerca recurrían a otros compañeros o amigos para practicar o simplemente divertirse. Pero hay más, hemos encontrado una imagen que demuestra que no sólo se bailaba entre hombres, sino también entre mujeres. Esta imagen es de 1900 y nos muestra unas cuantas parejas bailando en la romería de San Isidro de ese año. Vemos varias parejas, dos de ellas formadas solo por mujeres. También sabemos, por la documentación que presenta Marcelo Castelo en una conferencia emitida en streaming el 19 de diciembre de $2020^{302}$ que existieron parejas de bailarinas profesionales que gozaron de una importante relevancia tanto en Argentina como en el extranjero. Concretamente nos habla de María Cores y Olympia D'Avigny, primera pareja de bailarinas profesionales que recorren el mundo bailando el tango argentino. Estamos hablando del año 1906 y debemos aclarar que según los documentos presentados en esa conferencia podemos afirmar que

301 Blas Matamoro, La ciudad del tango. Tango histórico y sociedad (Buenos Aires: Editorial Galerna, 1969), 74.

302 Marcelo Castelo y Guillermo Elías, Las mujeres en el tango a comienzos del siglo $X X$, https://www.youtube.com/watch?v=pvVRvE-CJQ0, acceso el 20 de junio de 2021. 
ya en los primeros años del siglo XX el tango estaba generalizado en Europa y en Estados Unidos desmintiendo, por tanto, la teoría de que los niños bien llevaron el tango a París y allí, gracias a un proceso conocido como adecentamiento, se popularizó definitivamente para ser exportado a todo el mundo.

Volviendo al controvertido tango entre hombres nos gustaría hacer referencia ahora a las imágenes recogidas en Caras y Caretas en las que encontramos parejas de hombres bailando. Corresponden a números de 1903, 1906, 1907 y $1912^{303}$ y solo en las imágenes de 1903 — de la que ya hablaba Matamoro- y en la de 1912 nos concretan que lo que bailan es tango. En las demás no lo dicen, pero a simple vista podríamos afirmar que lo es. Todas estas imágenes pertenecen a la conocida como Guardia Vieja por lo tanto, si lo que nos cuentan es cierto, estos hombres estarían bailando tango al estilo canyengue. De esto hablaremos un poco más adelante porque estos registros nos aportan datos más importantes sobre otros aspectos de la historia del tango. En cuanto al hecho de que sean parejas estrictamente masculinas creemos que, sabiendo que existían por esa misma época y épocas anteriores parejas también de mujeres, lo más lógico es afirmar que es un hecho aislado y coyuntural determinado por circunstancias como cuántas mujeres o cuántos hombres había presentes en esos momentos dispuestos a bailar. Nos adherimos pues a la teoría de que el tango no se bailaba estrictamente entre hombres en sus orígenes. Si bien, nos queda claro que el hecho de que de forma natural fuese practicado por parejas de hombres o de mujeres, nos hace pensar en que la fórmula de pareja hombre-mujer no tenía aún las connotaciones de sexo y género que observamos en años posteriores. Por lo tanto, en esta primera época, y a pesar de lo que nos contaron más tarde, el tango se bailaba con naturalidad y tenía una finalidad exclusivamente lúdica. Más tarde entraría en escena la exacerbación de esa masculinidad que cambiaría para siempre la imagen del género.

${ }^{303}$ Las fechas de publicación de estos números son respectivamente: 7 de febrero de 1903, 15 de setiembre de 1906, 13 de abril de 1907 y 20 de enero de 1912. 
Entrando de lleno en lo que actualmente se conoce como tango canyengue afirmamos, en primer lugar, que presenta unos rasgos completamente diferentes al tango salón, en especial en lo que tiene que ver con la relación entre los dos bailarines. El abrazo es diferente, el eje se sitúa en otra zona del cuerpo y los pasos trazan un camino distinto. Veámoslo parte por parte. En el abrazo, los bailarines no se enfrentan, sino que el ombligo de la mujer coincide con la cadera derecha del hombre. En definitiva, el abrazo se cierra en el abdomen. Queda así establecida la principal diferencia con respecto al resto de los estilos que nos permite reconocer visualmente el tango canyengue.

Los rasgos musicales de este estilo son también fácilmente reconocibles. Todos ellos los encontramos en la música de estilo tradicionalista de, entre otros, Francisco Canaro, por establecer un referente conocido por todos. Se podría decir que él es el más claro representante musicalmente hablando de este estilo: frases melódicas cortas, ritmo muy marcado y carácter festivo. La caminada adquiere en este tango un peso considerable, es decir, los pies intentan meterse en el piso ${ }^{304}$.

En los anexos audiovisuales presentamos unos ejemplos de tango canyengue donde los bailarines Laura Collavini y Gustavo Negrotto nos interpretan el más puro estilo canyengue. ${ }^{305}$ En estos vídeos comprobamos que efectivamente este estilo tiene el carácter festivo que se le atribuye a los primeros tangos, cuando aún ni la melancolía ni la nostalgia habían llegado para quedarse. Cuando vemos una pareja bailando este tipo de tango no observamos más que un baile popular donde dos personas se divierten rememorando, los que supuestamente fueron los eventos sociales de finales del s. XIX y principios del XX.

¿Por qué en este estilo supuestamente decimonónico aún no observamos la exacerbada masculinidad que invadirá el tango salón y, sobre todo, el tango show? ¿Por qué los roles femenino y masculino no parecen tan

\footnotetext{
${ }^{304}$ La expresión meterse en el piso al hablar de danza quiere decir dar pasos firmes como si se fuera a atravesar el suelo.

${ }^{305}$ Ver DVD adjunto.
} 
estrictamente diferenciados en este como en otros estilos? En esta primera época, y a pesar de lo que nos contaron más tarde, el tango se bailaba con naturalidad y tenía una finalidad exclusivamente lúdica. Esto encaja perfectamente con lo que Jorge Luis Borges contaba del tango divertido de los primeros años. Más tarde entraría en escena la exacerbación de esa masculinidad que cambiaría para siempre la imagen del género. Para demostrar estas afirmaciones es necesario que aportemos los datos con los que contamos y que nos permiten saber si lo que nos cuentan sobre este estilo de tango realmente es cierto.

En primer lugar, diremos que la única referencia escrita que conocemos sobre este estilo es la que encontramos en las memorias de Francisco Canaro, escritas en 1956, cuando habla de su época en el Cabaret Montmartre, aproximadamente, en 1917:

«Además de Fresedo, que tocaba el bandoneón, formaban parte de mi orquesta José Martínez al piano, un español cuyo nombre no recuerdo que actuaba de segundo violín, y el contrabajo a cargo de Leopoldo Thompson, creador en mi orquesta del compás llamado "Canyengue", que ahora lo hacen casi todos los contrabajistas de orquestas Típicas, y que consiste en golpear con el arco y la mano izquierda sobre las cuerdas del instrumento en combinación con el piano y los bandoneones a tiempo y contratiempo, lo que da al tango un ritmo de proporción simétrica y de cadencia bien acompasada que le infunden alegría y movimiento a nuestra popular danza». ${ }^{306}$

No está documentada otra referencia al estilo canyengue hasta el momento. Esta novedad rítmica de la que nos habla Canaro afectaría a la danza del tango en años posteriores a 1916, según lo que nos cuenta en su libro. En aquel año el tango tenía ya varias décadas de historia así que ese modo de bailar no podría haber sido el característico de los primeros años.

José Gobello y Oscar Conde, en sus respectivos diccionarios de lunfardo definen el término canyengue, entre otras acepciones, como

${ }^{306}$ Francisco Canaro, Mis bodas de oro con el tango. Mis memorias (1906-1956), (Buenos Aires: CESA Talleres Gráficos S.R.L, 1957). 
«arrabalero, de baja condición social» ${ }^{307}$ y Gobello, además, añade «Actitud, postura del cuerpo afectada como la habitual de los compadritos», pero de la época en la que supuestamente definía un estilo de tango, no hemos encontrado nada.

Lo que sí tenemos son fotografías e ilustraciones del tango de aquella época recabadas de entre los números publicados de Caras y Caretas entre 1898 y 1915 . De algunas ya hemos hablado en capítulos anteriores y al hablar de la polémica acerca del tango entre hombres, pero hay más. Veamos lo que podemos deducir de su análisis. Las primeras imágenes en las que reconocemos lo que parece un tango datan de 1899 y 1902, pero en el texto que acompaña a las ilustraciones no hablan de tango, sino de habanera.

El primer artículo que habla del tango criollo en este semanario data de 1903 y lo más relevante que leemos en él, dejando de lado el hecho ya comentado de las imágenes de parejas exclusivamente masculinas, es que nos habla ya del tango como un género en agonía. Afirma que lo que en ese momento se baila nada tiene que ver con el verdadero tango de los compadres de antaño:

«No son estas figuras aquellas pintorescas del clásico salón del baile-pago, donde reinaban soberanos el corte y la quebrada y la gentil comadrita de puñal en la liga, que lo mismo se apuntaba en una gresca que en un lance de amor o en una intriga». ${ }^{308}$

Según este artículo, el tango de compadritos del que tanto se ha hablado no estaba ya vigente en el siglo XX. Sería simplemente un baile que aún recordaban y bailaban una minoría de aficionados, pero del que no tenemos constancia gráfica ni textual.

Hablan a continuación del cake-walk, que definen como el tango en inglés practicado en los Estados Unidos y desde donde habría llegado y triunfado en la capital francesa. De este baile tenemos noticia también tres

${ }^{307}$ Oscar Conde, Diccionario etimológico del lunfardo, $3^{\mathrm{a}}$ ed. (Buenos Aires: Editorial Taurus, 2019),87 y José Gobello, Diccionario lunfardo (Buenos Aires: Peña Lillo Editor, 1978), 44.

${ }^{308}$ Sargento Pita [seud.], «El tango criollo», Caras y Caretas, 227 (1903):43. 
meses después en el mismo semanario en la crónica de un baile de un batallón de infantería en Uruguay pero no volvemos a leer nada que lo relacione con nuestra música. A partir de 1910 se empieza a hablar del éxito del tango en París, aunque no se vuelve a mencionar el paso previo por Estados Unidos. Además, ya hemos desmentido gracias a las aportaciones del investigador Marcelo Castelo que el tango ya estaba en París mucho antes de esa fecha. Solo nos queda suponer que la fama del ambiente parisino entre las clases acomodadas durante los años previos a la Primera Guerra Mundial fomentó la divulgación de ese relato. Está claro que para los que hacen y supuestamente para los que leen Caras y Caretas, por muchos otros aspectos que nada tienen que ver con el tango, París es la referencia.

Todas las imágenes que encontramos en este recorrido desde 1898 hasta años antes de la Gran Guerra nos muestran un tango que nada tiene que ver visualmente con el que bailan Laura Collavini y Gustavo Negrotto, pareja de referencia actualmente en Buenos Aires en lo que se refiere al canyengue. No se respetan los patrones relacionados con el abrazo y la caminada. De hecho, encontramos diferentes posiciones que nos hacen pensar en cierta libertad de movimientos y no en un rígido modelo de estilos. Por tanto, no se puede afirmar que en la Guardia Vieja se bailaba el tango que ahora llamamos canyengue, quizá se bailaba un tango diferente al posterior, pero nada tan diferenciado como lo es actualmente ese estilo. Lo que sí tenemos claro y lo reiteramos ahora es que la gran diferencia entre este estilo y los demás es que el rol masculino en el canyengue no está tan masculinizado, valga la redundancia, como en aquellos. Asimismo, aunque este no sea el estilo de los comienzos, si nos lo han presentado preferentemente como tal y si alguien quiere reproducir una danza divertida y popular debe dejar de lado esa imagen hipermasculinizada del rol del hombre. Los compadritos y su gesto chulesco aún no se han convertido —o aún no los han convertido- en protagonistas de la historia del tango porque la mitificación no se ha consagrado todavía. Aún no hay historias del tango, no ha pasado el tiempo suficiente como para que se quiera hablar de cómo surgió o de qué contextos protagonizaba. Será más tarde, en los años 30 cuando se intenten recuperar tradiciones y símbolos que configuren una identidad 
nacional y con ello se irá configurando una nueva estética a la que recurrirán los bailarines cuando en los años ochenta el tango, de nuevo como danza, resurja de sus cenizas después de más de tres décadas de vivir en un casi absoluto olvido.

Y para concluir nuestras líneas dedicadas al estilo canyengue no debemos dejar de intentar responder a la siguiente cuestión. Si este estilo no fue el característico de la Guardia Vieja, ¿cuándo se creó y con qué finalidad? Para responder a esta pregunta recurrimos de nuevo a las fuentes aún inéditas que nos aporta la investigación del profesor y experto en tango Marcelo Castelo. En la entrevista ${ }^{309}$ emitida en Radiouniversidad de Salamanca a este investigador, nos habla de una conversación con Mirta Sol, componente junto a su marido Luis Grondona del dúo Los reyes del canyengue. Durante muchos años fueron la referencia en este estilo y su trayectoria se desarrolló por todo el mundo. Pues bien, en esa conversación, la bailarina les habla de cómo en los años 80 su pareja y ella inventan el estilo. Señala a El Cachafaz como referente pero los pasos característicos que observábamos en la interpretación de Laura Collavini y su compañero, según les cuenta, los fueron inventando poco a poco. De esa manera se fue creando ese estilo que posteriormente y, seguramente, por motivos comerciales se fue identificando como estilo primigenio del género. Recordemos que en los años ochenta se asiste al gran resurgimiento del tango y en un momento de tal ebullición es siempre necesaria una búsqueda de referentes. Fue un momento perfecto para que la nueva teoría calara entre los aficionados y es más que lógico que los profesores e intérpretes actuales, interesados simplemente en el baile, transmitan actualmente lo que se contó del estilo canyengue durante estas últimas décadas.

Como conclusión y ateniéndonos a lo que nos interesa en nuestro trabajo que es demostrar el poder de la masculinidad para determinar la coreografía del tango entre otros aspectos, debemos afirmar que en este estilo que acabamos de definir no está claro ese impacto. Como ya adelantamos, lo

${ }^{309}$ Marcelo Castelo, entrevista por Laura Alonso, Alevare, Radiousal, podcast, 9 de febrero de 2021, acceso el 20 de junio de 2021, http://radio.usal.es/programa/alevare/. 
que explica esto es que lo que pretende el canyengue es recrear y rememorar un baile popular y divertido en el que aún no se atribuían los rasgos que definían a la parte masculina de la pareja. La preocupación del hombre en este baile aún no es mostrar sus dotes de seducción y de poder, sino simplemente disfrutar.

\subsubsection{Tango milonguero y tango de salón:}

Analizamos de manera conjunta estos dos estilos porque nos parece que, en lo que respecta a nuestros intereses, no se diferencian demasiado. Son los estilos más bailados y más populares en las milongas de todo el mundo. Se trata de una danza más aséptica que el canyengue. Es más formal, más académica y, en nuestra opinión, menos visceral.

Con respecto a los elementos básicos que definen el tango, el abrazo y la caminada, diremos que son completamente diferentes con respecto al canyengue. En este estilo el abrazo estaba en el abdomen, en el tango de salón y el milonguero la pareja se abraza en el pecho. Y será aquí donde podamos observar la diferencia más evidente entre el tango de salón y el milonguero. Este último es una danza muy apilada, el abrazo se cierra favoreciendo la posición de " $v$ " invertida. Es evidente que este rasgo facilita a los bailarines unos movimientos más abiertos y más rápidos. Probablemente uno de los pasos más atractivos que permite este estilo sea el balanceo. Es fácil deducir que el apelativo milonguero venga del hecho de que se baila en la milonga. Esto quiere decir que se interpreta junto a un grupo de parejas que podría ser muy numeroso. Seguramente el hecho de bailar junto a mucha gente haya favorecido la ejecución de un abrazo más cerrado. Además, el baile social también obliga a la adquisición y asimilación de algunos códigos como el cabeceo o el modo de girar en la pista.

En cuanto a la postura del tango milonguero y su abrazo apilado, es decir, cerrado, nos gustaría comentar que, aunque es un estilo creado, según algunos investigadores como Marcelo Castelo, por la profesora de tango Susana Miller, nosotros hemos encontrado una ilustración en la revista Martín Fierro en la que podemos ver una pareja bailando tango en la posición anteriormente descrita como característica de este estilo. 


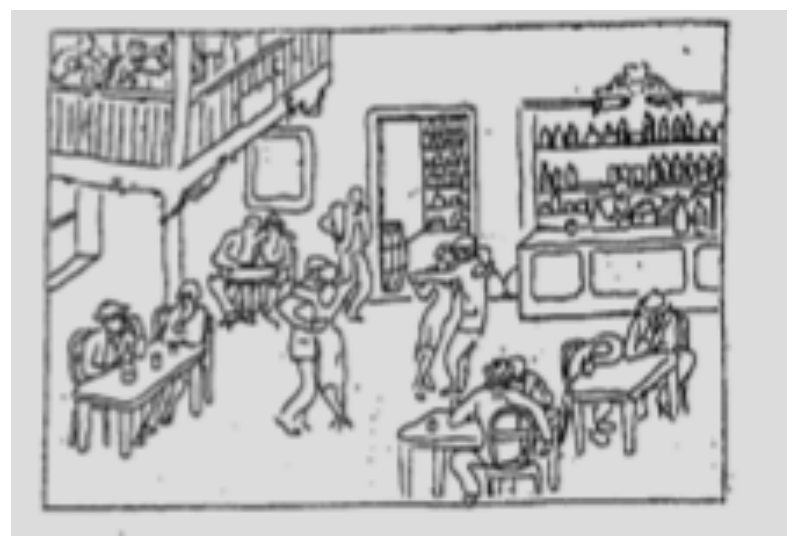

Figura 5. Imagen extraída de la revista Martín Fierro, n 20, página 144.

Como vemos en la pareja de bailarines de la derecha, estas posiciones que describimos en el estilo más popular en los años ochenta, ya existían en 1925.

En el tango de salón propiamente dicho los bailarines adoptan una posición paralela con un abrazo más abierto. Este estilo es el más académico, lo que significa que se establecieron unos pasos y unos giros más calculados y estudiados. Nos olvidamos ya de la naturalidad de las fiestas familiares o los encuentros sociales del canyengue o simplemente del tango más primigenio para dar paso a un espacio donde la gente va a bailar y debe seguir unos códigos muy concretos. Podríamos decir, para entender mejor la diferencia entre los dos contextos que en una reunión familiar el baile se añade a la conversación y el disfrute de los asistentes. En una milonga la mayor parte del tiempo se emplea para bailar y, de paso, entre tanda y tanda o en ratos en los que no se baila, se conversa con otros milongueros. En cuanto a los pasos y a las figuras concretas, vemos en los estilos de salón y milonguero una gran ligereza. Los pies se van arrastrando por el suelo y no parece que quieran atravesarlo, como sucedía en el tango canyengue.

En $1916^{310}$ se publica el más antiguo método de baile que conocemos para aprender el tango argentino de salón. Nicanor Lima, su autor, dice ya

${ }^{310}$ El investigador Marcelo Castelo manifiesta dudas acerca de la fecha de edición y de publicación de este manual, pero no hemos encontrado datos que refieran una alternativa. 
antes del prólogo del libro que al aprender a bailar este género también se facilita la práctica de otros como el vals, la polka, la mazurka o el schottisch. Esto nos da una pista ya de lo que vamos a encontrar en el manual: la práctica de una técnica que abarca muchos estilos bailados en la época y que, aunque expresada a través del tango, quiere definir un modo de bailar que ha estado muy condicionado por las danzas cortesanas de procedencia europea. Por ello deducimos que este tipo de tango tiene que ser muy diferente al de los comienzos, que imaginamos más natural, más cerca de lo que podría ser el canyengue. Pero sobre todo lo que diferencia este estilo de los otros es su intención y esto queda muy claro en el método de baile de Nicanor Lima.

El tango se fue modificando como sucede con todo baile en boga. Lima parece haber sido uno de aquellos que intentaron aportar al género la decencia suficiente como para poder diferenciarlo de lo que llamaron tango orillero o prostibulario. Ese del que hablaban en Caras y Caretas en el año 1903. De hecho, iban más allá, proponiendo este tango como el auténtico.

A pesar de tener claro que es imposible saber exactamente cómo se bailaron los primeros tangos, sí estamos seguros de que el tango de la primera década del siglo $X X$ recibió una gran influencia de los bailes de salón europeos a los que hemos hecho referencia al hablar de otras danzas de la época. Algunos como Nicanor Lima, así como el poeta que firma el prólogo del manual, Dermidio T. González, entendieron que el tango debía ser mutilado para poder ascender en la escala social y alejarse lo más posible del primer tango orillero:

«Claro está que el tango que baila el orillero o nuestro tipo compadre, merece nuestra más severa censura.

En este sentido, el autor de esta obra, con un noble espíritu patriótico quiere contribuir en la medida de sus fuerzas, a la difusión de su escuela de baile de tango, de acuerdo con las reglas más elementales impuestas por la gentileza, la corrección y la moralidad, a fin de que el popular baile Argentino pueda ser 
bailado sin temores, sin escrúpulos mal disimulados e injustos y con absoluta tranquilidad en cualquier salón.» ${ }^{311}$

Así, más que un método de baile, en las primeras páginas el libro parece un manual de cómo comportarse en sociedad y así, el tango que explica a continuación paso por paso se convierte en algo cerrado, libre de improvisación y absolutamente hermético. Nada que ver con una celebración popular divertida y espontánea. Recordemos que en 1916 hace ya unos años que el tango ha llegado a París, mientras el mundo occidental está inmerso en la Gran Guerra.

Este adecentamiento del que tanto se ha hablado en distintos libros y artículos de tango podría ser el origen del tango de salón. $Y$ de nuevo aquí tenemos que establecer la diferencia entre cómo se sucedieron los hechos y cómo fueron relatados. La teoría de que el tango triunfó en París en los años previos a la Primera Guerra Mundial llevado allí por los niños bien no se sostiene en opinión de expertos como la Dra. Marta Rosalía Norese o Marcelo Castelo, como ya comentamos anteriormente. Lo que sí es evidente es, en primer lugar, la influencia que la música y la danza europeas ejercieron sobre la sociedad rioplatense, véase la cantidad de danzas europeas que encontramos en las celebraciones de las que se habla en el semanario Caras y Caretas. En segundo lugar, que el tango salón existe y que tiene un carácter más académico que otros como, por ejemplo, el canyengue. Haya sido o no fruto de su paso por París, lo que a nosotros nos interesa es observar la la representación escénica de lo masculino en este estilo.

Como podemos ver en los vídeos anexos, el modo de bailar de un hombre nacido en los años veinte o treinta difiere bastante del modo que observamos en los bailarines más modernos. Y aquí, de nuevo, lo que vemos es una exageración cada vez mayor de los rasgos masculinos. Los hombres de cierta edad como vemos en los vídeos del Toto Faraldo y del maestro Jorge García bailan de un modo más espontáneo, natural y divertido. En los

311 Nicanor Lima, El tango argentino de salón: método de baile teórico y práctico. $1^{a}$ Parte, Edición de Autor (¿1916?). Encontramos la referencia a esta fecha de publicación en Carlos Vega, Estudios para los orígenes del tango argentino (Buenos Aires: Universidad Católica Argentina. Instituto de Investigación Musicológica Carlos Vega, 2016), 205. 
milongueros más jóvenes observamos una intención más impostada y exhibicionista. De hecho, vamos a ver estos rasgos mucho más claramente en el tango show. Esto nos lleva a pensar que fue con el renacimiento del tango que se establecieron los estilos de tango y no tiene tanto que ver la trayectoria anterior del género. Al igual que el canyengue quiere remedar los primeros años del tango, el tango de salón pretende dejar constancia del influjo europeo en el género rioplatense. La comparación entre bailarines de avanzada edad con los más jóvenes nos lleva de nuevo a pensar en que lo que va perdiendo la danza del tango a medida que pasan los años es, ante todo, espontaneidad.

El modo en el que se manifiesta la masculinidad en estos estilos tiene que ver con la función o rol del hombre. Observamos en los vídeos de Susana Miller, a quien como hemos dicho algunos atribuyen la creación de este género, que la parte masculina se basa casi exclusivamente en una caminada -también conocida como caminata - ligera que va marcando los pasos que debe o puede dar la mujer. Es esta quien da el toque de ornamentación al baile. Esto nos recuerda a lo que algunos medios y algunos escritores nos contaban de cómo el compadrito empleaba la milonga como lugar de exhibición. Él favorecía el lucimiento de su pareja y eso demostraba su habilidad en el baile y, por consiguiente, con las mujeres. Se refleja por tanto en este estilo la mitología que expusimos en los primeros capítulos y que fomentaron tanto intelectuales como literatos o periodistas.

En definitiva, el tango de salón y el milonguero - al igual que el nuevo y fantasía, como veremos a continuación - se diferencian en gran medida del canyengue. $Y$ a partir de este tango que se hará universal en su apogeo de los años ochenta, surgirán los dos estilos que vamos a comentar y que no son más que variantes de este, teniendo en cuenta que tienen distintos contextos, diferentes intenciones, diferente puesta en escena, pero exacta estructura.

Por último, y para dejar clara la diferencia esencial entre el tango de los comienzos y el que triunfa a partir de los años ochenta con un sistema más académico y menos espontáneo, hacemos referencia a una anécdota que Lidia Ferrari, psicóloga, bailarina y docente de tango, cuenta en su libro Tango. Arte y misterio de un baile en 2017. En el capítulo dedicado a analizar 
los estilos de tango nos presenta el caso de un alumno septuagenario que asistió a sus clases durante algún tiempo. Ferrari nos muestra la naturalidad con la que este hombre, Verdun, afrontaba la danza del tango. Había aprendido en reuniones familiares durante su juventud de una manera espontánea, e interpretaba el tango sin grandes adornos, solo sintiendo la música y moviéndose según lo que esta le iba transmitiendo. No conocía los pasos ni era capaz de analizar cada movimiento como lo hacen habitualmente quienes enseñan esta danza porque él la había aprendido casi de un modo inconsciente. Ni siquiera había vuelto a bailar desde hacía décadas, y eso no le impidió volver a disfrutar en seguida del tango. La autora se plantea tras explicar el caso de su experimentado alumno una serie de preguntas que nos sirven para concluir este apartado:

«¿Se podría pensar que el estilo Verdun es más auténtico que otros? Sería un disparate. ¿Se podría decir que la sencillez de Verdun es la del verdadero tango? Nada más lejano que eso. ¿Se trata de convertir a Verdun en modelo a imitar? No, porque es inimitable». ${ }^{312}$

Efectivamente nos parece un sinsentido intentar saber qué tango es más o menos auténtico o verdadero, por ser éstas categorías que no consideramos susceptibles de ser aplicadas a un género musical. Sin embargo, sí podemos afirmar que el tango que bailaba Verdun y que nosotros identificamos con el canyengue o al menos con la época que quiere evocar, gozaba de un rasgo que para bien o para mal se pierde cuando despunta el tango de salón: la naturalidad.

\subsubsection{Otros estilos populares. El Tango nuevo.}

El auge del tango en las últimas décadas del siglo $\mathrm{XX}$ dio lugar al establecimiento de los tres estilos de los que ya hemos hablado, que quedaron perfectamente asentados en el ambiente de la danza y que perviven aún en la actualidad. Además de estos y por la inercia de todas las artes de seguir evolucionando, surgieron además otros estilos menores como el Tango

312 Lidia Ferrari, Tango. Arte y misterio de un baile (Buenos Aires: Ediciones Corregidor, 2017), 59. 
nuevo. Empleamos el apelativo menores porque, como veremos al explicar los detalles que lo definen, no supusieron - 0 , al menos, por el momento- una verdadera evolución en la estructura coreográfica del género, sino simplemente se podrían considerar ampliaciones de distintos aspectos de la danza y en algunos casos meros experimentos de profesores o milongueros para crear algo nuevo. Además, estos estilos no dejaron la impronta de los anteriores y se reducen a meras aventuras efímeras.

Si habláramos del tango desde un punto de vista global deberíamos decir que el Tango Nuevo es esa rama del género que surge con los músicos vanguardistas de los años cuarenta y cincuenta, especialmente Astor Piazzolla. Debemos detenernos aquí para recordar lo que supuso la música de Piazzolla y por qué ejerció tanta influencia en el modo de bailar.

Este bandoneonista de formación clásica nacido en Mar del Plata en 1921 consiguió, a pesar de desatar una gran polémica, convertir el tango en algo que no había sido nunca desde su creación: música para ser escuchada. La danza como instrumento popular se deja a un lado y con un sonido absolutamente nuevo Astor Piazzolla consigue que el tango sea un género fundamentalmente instrumental. Tal fue el cambio que supuso este compositor, que algunos afirmaron que lo que él hacía no era tango. Fusionó el género tradicional con el jazz y la música académica, entre otros estilos. En esta renovación del tango fue fundamental la labor de sus maestros como Alberto Ginastera y Nadia Boulanger. Su tercer maestro, en sus propias palabras, fue Buenos Aires. Otro elemento determinante en este proceso transgresor fue la fundación en 1957 de su Octeto de Buenos Aires, integrado por músicos tan relevantes del tango como Atilio Stampone o Leopoldo Federico. Algunos afirman que en ningún otro momento la música de Piazzolla alcanzó tan alto grado de creatividad como en los años que estuvo en activo su octeto.

A este tango se le llamó Tango Nuevo y en un determinado momento los bailarines también quisieron integrarlo en sus coreografías. La música piazzolliana siempre fue complicada para una pareja acostumbrada al tango más sencillo, rítmico y popular. Pero eso no impidió que el concepto Tango 
Nuevo representara también un nuevo modo de bailar, que describimos a continuación.

En este contexto debemos aclarar que nos referimos aquí a este subgénero o estilo como una danza que emplea esta nueva música y en algunos casos mezcla el tango con otros ritmos como el swing o la salsa y que no depende sólo de ser acompañada de música de tango para ser bailada. El Tango Nuevo recoge los pasos y las bases del tango de siempre y lo hace evolucionar. En ocasiones lo imbrica en cualquier tipo de música. Así, podemos acudir a milongas donde los bailarines bailen tango con música rock, por ejemplo.

Es evidente que el Tango Nuevo en la danza, al igual que sucedió con el tango electrónico desde el punto de vista de la estética, supuso una apertura a nuevas posibilidades en un momento de cambio de referentes morales y de consumo. Este afán de renovación tiene lugar ya en el siglo XXI y pretende romper con el establishment tanguero. Dentro de este afán revolucionario surge también el Tango queer ya mencionado:

«En síntesis, las nuevas propuestas intentan crear espacios de apertura hacia la exploración: el tango queer focalizado en la dinámica comunicativa de la pareja de baile y el tango nuevo en los movimientos corporales. A su vez coinciden en que debe expresarse la individualidad de los cuerpos $y$, al eliminar la pretensión de homogeneidad de las acciones, se generan modificaciones en la pautación coreográfica; el tango nuevo porque busca la conexión corporal de cada individuo consigo mismo y el tango queer porque las combinaciones de la pareja se diversifican». ${ }^{313}$

Lo que nos interesa analizar en nuestro trabajo es la actitud de los bailarines y, dado que la documentación al respecto es escasa, hemos analizado los vídeos que presentamos, como decíamos en los estilos anteriores, en Anexos. Hemos seleccionado estos vídeos y no otros porque

313 María Mercedes Liska, «El tango como disciplinador de cuerpos ilegítimoslegitimados», Trans, 13 (2009), acceso el 12 de febrero de 2021, https://www.sibetrans.com/trans/articulo/53/el-tango-como-disciplinador-de-cuerposilegitimos-legitimados. 
en ellos vemos bailar e los máximos representantes del estilo, como hicimos con los anteriores.

Uno de los creadores del Tango nuevo es el bailarín y profesor Gustavo Naveira y será desarrollado también por otros como Chicho Frúmboli. Según observamos en los vídeos aportados, estos bailarines interpretan una mezcla de Tango de salón y Tango escenario. Tiene un carácter más relacionado con el espectáculo que con lo popular, pero la base es la misma que la del baile de salón. Es habitual que estos bailes estén apoyados en música de Piazzolla o de músicos posteriores que siguieron su legado.

El semblante serio y algo altivo, la espalda recta y el desarrollo estricto del rol masculino en el hombre nos muestran una actitud que muchos de los que hemos nombrado en nuestro estudio describirían como viril o varonil. Recordamos que no es nuestro objetivo hacer un trabajo de género, no juzgamos el por qué de esa actitud, sino que lo consideramos parte de la estética y, por lo tanto, de la puesta en escena. Son rasgos que se han conservado y fomentado en la danza del tango y nosotros intentamos despejar la incógnita del cómo, no del por qué.

En cuanto al tango queer ya hemos dejado claro que lo consideramos fuera de nuestro centro de interés puesto que la revolución que este tipo de tango supuso tiene que ver con razones de género y de intercambio de roles, pero no con el desarrollo sensible de la danza. Podríamos decir que dentro de este género nuevo que sería el queer son susceptibles de ser incluidos de nuevo todos los estilos de tango que estamos describiendo, aunque con un punto de partida muy distinto. Tiene que ver más con los códigos sociales, como nos deja claro Sofía Cecconi:

«Se trata de bailarlo y expresarlo sin atarse a las normas que rigen en las milongas "clásicas" "reglas defendidas por los sectores más tradicionalistas", referidas principalmente a la conformación de las parejas de baile y a los roles asignados a varones y mujeres en el curso de la danza. Así, quienes adscriben a esta propuesta sostienen que no hay razón para que el baile se desarrolle exclusivamente en el marco de una pareja "heterosexual" (varón/mujer); 
tampoco para que el varón sea per se quien ocupa el rol de "conductor" ni, a la inversa, para que la mujer sea ubicada en el rol de "conducida". .»"

Nos parece muy interesante recoger aquí la relación que Cecconi establece en su artículo entre el Tango queer y el polémico tango entre hombres de los comienzos. En concreto habla del pasado queer del tango y destaca la diversidad sexual de los primeros años del tango donde el ambiente era poco definido en lo que a identidades sexuales se refiere. Recoge así el relato mítico que afirma que el tango se bailaba únicamente entre hombres y reconoce en el género queer una vuelta a los orígenes:

«De algún modo, entonces, la propuesta del "tango queer" actual retoma o reedita la disidencia originaria del tango, aquella que tenía lugar en el prostíbulo, donde los cuerpos "abyectos" de prostitutas, malevos y maricas se cruzaban entre sí y con los cuerpos legítimos de "niños bien" que, por un rato, se desplazaban de esa posición para traspasar las fronteras de lo permitido». ${ }^{315}$

Nueve años más tarde recogen también esta idea José Javier Maristany y Jose Luis Peralta en el artículo que introduce su ensayo Cuerpos Minados:

«... no podemos olvidar los turbios orígenes homoeróticos de una danza bailada entre varones y, en la actualidad, los disidentes que vienen a imitar a aquellos pioneros, en las milongas queer de la ciudad de Buenos Aires». ${ }^{316}$

En todo caso y como ya afirmamos en el Estado de la Cuestión, estos trabajos tienen un objetivo muy diferente al nuestro, puesto que se centran en las relaciones de género y no en el punto de vista estético.

Volviendo a las versiones más innovadoras del tango agregamos el tango nuevo al grupo de estilos en los que la masculinidad se presenta como un elemento ineludible. Nos hallamos en el punto medio de un hipotético

314 Sofía Cecconi, «Tango Queer: territorio y performance de una apropiación divergente», Trans, 13 (2009).

315 Ibidem.

316 José Javier Maristany y Jorge Luis Peralta, «Masculinidades: modelos para (des)armar», Cuerpos minados (La plata: EDULO, 2017), 9-27. 
camino entre el tango más natural y el más elaborado, pero todos los estilos de los que hemos hablado transitan por él. La máxima expresión en el modo de elaborar coreografías del tango será el último del que hablaremos aquí, el tango escenario.

\subsubsection{Tango fantasía o tango escenario.}

El tango fantasía, más conocido actualmente como tango escenario, es el estilo que también se conoce como Tango Show. Es el tango como espectáculo, una danza trabajada hasta los últimos detalles desde diferentes puntos de vista — vestimenta, iluminación, gesto- donde la sorpresa del auditorio es el principal objetivo. Se incluyen, además de los pasos habituales, acrobacias y virtuosismos corporales que no están al alcance de cualquiera y esa es, en realidad, su intención. Se separa completamente de lo popular, de los orígenes, en definitiva. Representaría, como decíamos al concluir el párrafo anterior, la máxima expresión de la elaboración y, por tanto, la falta de improvisación y espontaneidad, en la danza del tango.

Como ejemplo de lo que se considera el mayor exponente del tango show o tango fantasía presentamos en Anexos las coreografías de las diecisiete parejas ganadoras del Mundial de tango en la categoría de tango escenario. En este Mundial que se celebra desde el año 2003 se puede competir también en la categoría de tango salón. Abordamos a continuación el análisis de las últimas cinco coreografías ganadoras del Mundial, aunque anexamos las diecisiete para que quede constancia de que las conclusiones valdrían para cualquiera de ellas.

En estos vídeos está representado perfectamente lo que significa este estilo de tango: espectáculo, brillo y representación. Es decir, todo lo contrario de lo popular. De hecho, las normas del certamen permiten emplear pasos y movimientos de otras danzas, si estas no ocupan más de un tercio de la escenificación.

Lo que define estas coreografías, en nuestra opinión, es el empleo de los tempos para el lucimiento de los bailarines. Se emplea el tempo lento para recrearse en la interpretación, en la mayoría de los casos, con gestos impostados. Los tempos rápidos son aprovechados para mostrar el 
virtuosismo en los pasos - con empleo, fundamentalmente, de una mayor velocidad - añadiendo acrobacias que causan verdadero asombro en el espectador.

Otro elemento fundamental para entender lo que representa el tango show, tango fantasía o tango escenario es el espacio. En ninguno de los estilos anteriores los bailarines cuentan con tanto espacio para el desarrollo de la danza. Quizá en el caso del tango primigenio pudiera darse el caso de que las parejas practicaran en patios o en casas, pero lo habitual y lo que nos interesa en este trabajo es que era un baile popular y, por tanto, bailado en fiestas y encuentros sociales. En el tango de salón y el milonguero los bailarines comparten pista en la milonga y están obligados a pasos más cortos y a respetar unos códigos que no permiten tan alto grado de lucimiento.

De todos estos rasgos que hemos descrito nos quedamos ahora con el que más nos interesa: la interpretación. Entendemos interpretación como empleo de gestos, movimientos y vestuario -en el caso de la danza- para dar forma a una idea que queremos representar. Cada una de estas parejas escoge con mucha cautela la música que va a interpretar el día del espectáculo o, en este caso, certamen. Ensayan durante meses una coreografía que durará unos tres o cuatro minutos y en ese corto período de tiempo deben demostrar todo lo que saben hacer. Además de la agilidad en los movimientos deben cuidar en extremo su imagen y lo que observamos es lo que exponemos a continuación.

Los hombres visten traje oscuro y las mujeres vestidos brillantes y espectaculares, un estudiado contraste. Generalmente los giros y pasos más asombrosos los realiza ella, con la decidida dirección de él. De nuevo él oscuro, ella brillante. Pero en un momento del espectáculo él hace un movimiento sorprendente, no sólo por su virtuosismo, sino por lo inusual de ver a un hombre perdiendo su correcta y muy estudiada postura.

Es evidente que los tiempos cambian y que en estas cinco actuaciones observamos cómo los roles se intercambian en algún momento, pero la visión global del espectáculo nos ofrece una lectura que recuerda mucho a la leyenda de los compadritos luciéndose en las primeras décadas del XIX a través de los movimientos de su pareja. El cuidado vestuario, el cuerpo 
erguido y el gesto serio y altivo en contraste con la sonrisa y el brillo de la mujer. Esta estructura y este carácter tan masculino del bailarín se ve especialmente claro en la pareja ganadora del Mundial de tango de $2014^{317}$.

Destaca entre las actuaciones que presentamos anexas la de los campeones mundiales de 2016. En este caso los bailarines escogieron la Balada para un loco de Astor Piazzolla y Horacio Ferrer y decidieron, además, representar la historia que cuenta. Adquieren entonces los bailarines otros roles en su interpretación, interiorizan el contenido de la canción. Ya no son una pareja de bailarines en un certamen de tango, sino que adquieren la personalidad de un 'piantao'318 y una mujer a la que quiere convencer de quererlo como es y demostrar así el valor del verdadero amor. No se aprecian en este espectáculo los roles que describimos habituales en este estilo de tango y lo proponemos como excepción puesto que en realidad es una representación, no un modo corriente de afrontar el tango show.

Abríamos este trabajo refiriéndonos a la imagen que le viene a la mente a la mayoría de las personas que alguna vez se han acercado al tango. Pero también nos referimos a ilustraciones y fotografías que inundan los carteles publicitarios relacionados con algún evento de tango o alguna otra experiencia relacionada con él. En definitiva, la imagen pública del tango. Pues bien, destaca entre todas esas representaciones la que sigue el patrón de presentar una pareja abrazada, con una vestimenta determinada y un gesto muy característico. Esa imagen no nos lleva precisamente a pensar en las romerías españolas o los bailes populares en veredas y conventillos. En nuestra opinión, está mucho más relacionada con la imagen de este último tango del que hemos hablado, el tango escenario. El rasgo más característico que hemos resaltado en este estilo es la actitud de la pareja que para nosotros procede, sin ninguna duda, de una exaltación de la masculinidad tal y como se entendía décadas atrás. Por eso, hemos indagado en algunos aspectos relacionados directa o indirectamente con el tango como son la literatura, el lunfardo o los propios tangos. Ha quedado perfectamente demostrado que la

\footnotetext{
317 Véase DVD adjunto.

${ }^{318}$ Piantao es un modo popular del habla lunfarda que significa maniático, loco.
} 
virilidad, entendida como manifestación extrema de coraje, fuerza y contención, ha sido un elemento muy relevante en todos esos ámbitos relacionados de alguna manera con el tango desde que empezó a hablarse de él. Por todo ello, no es de extrañar que la expresión más elaborada de esta danza haya recogido todos esos elementos y los muestre como propios del género. Los tiempos están cambiando y las relaciones de género han evolucionado mucho pero aún no ha pasado el tiempo suficiente como para que otros patrones estéticos dominen la imagen del tango. Parece que, por ahora, el público en general admira y pretende imitar esa actitud que, como hemos demostrado, domina aún en esta música rioplatense.

Sin embargo, aún nos queda un último punto que nos ayude a entender cómo esa imagen llegó a todo el mundo. Pasemos a exponer cómo todo este alarde de masculinidad fue atribuido a dos de las figuras más famosas del tango y cómo sus respectivas trayectorias artísticas y personales consiguieron definitivamente establecer la imagen altanera del hombre como propia del tango.

\subsection{Iconos masculinos del tango.}

Para entender este camino mitológico que el tango y, en concreto, su coreografía, recorre desde finales del s. XIX hasta la actualidad debemos detenernos en otros momentos de la historia de este género que ayudaron a ratificar y a consagrar esta estética, como vemos, eminentemente masculina. Nos vamos a apoyar para ello en dos de sus más conocidos cantores: Carlos Gardel y Julio Sosa. Las razones para escoger al primero son evidentes, nadie como él consiguió que el tango llegara a todo el mundo, su carisma, su fatídica muerte y su modo de cantar recorrieron el planeta y, con ellos, una manera de entender el tango. En cuanto a Julio Sosa debemos decir que, además de ser un gran representante del tango canción, con su figura se consagra definitivamente ese tango macho del que tanto se ha hablado y podemos ver en él quizá lo que algunos quieren ver en Gardel, aunque en nuestra opinión no pueden estar más equivocados. Julio Sosa fue, junto con Roberto Goyeneche, El Polaco, de los poquísimos intérpretes de tango que mantuvieron su popularidad en los años más difíciles para el género y lo hizo 
reivindicando el tango como seña de identidad de lo argentino frente a los nuevos géneros invasores. Esta defensa se apoyó, fundamentalmente en la identificación de lo argentino con lo 'macho'.

A continuación, analizamos la trayectoria de estas dos figuras que, si bien consiguieron convencer de la hombría del tango, no siempre lo hicieron conscientemente. De nuevo funciona aquí la maquinaria mitológica de la que hablamos en nuestra Introducción.

\subsubsection{Carlos Gardel.}

La poetisa e investigadora Martina Iñiguez, especialista en la figura de El Zorzal lo define así:

«De origen fatalmente arrabalero, enancado en la trama de lo urbano, en tren de rompe y raja ciudadano paseaste tu linaje callejero.

En los fueyes, tu canto compañero fue chamuyo, polenta y cotidiano, en quebradas y cortes diste ufano lustre al sino de vate milonguero. Gomía del vivanco y del obrero, de las minas, la vieja o el fulano que en cana se desgasta gris, cabrero.

Como Gardel, sos mítico y lozano, inmortal, bien porteño, sensiblero... ¡Sos el Tango y de yapa, sos humano!»» ${ }^{319}$

Carlos Gardel ha sido desde su aparición la referencia para músicos y cantantes por su modo de interpretar tangos que enamoró al mundo entero, pero su prematura muerte también lo convirtió en un mito. Por ello conocemos su imagen y la tenemos tan presente. ¿Es esta imagen también la referencia para esos bailarines y cantantes de tango que se visten como él? ¿Contribuyó

319 Martina Iñiguez, «Como Gardel», acceso el 27 de febrero de 2021 , https://www.todotango.com/musica/tema/1328/Como-Gardel/. 
también Gardel a perpetuar la figura y los gestos del hombre decimonónico en la danza del tango?

El objetivo de esta parte de nuestro estudio es buscar respuestas o parte de ellas tanto en su trayectoria personal y profesional como en algunas de sus películas. Para ello, además de referencias biográficas hemos recurrido a las películas en las que trabajó dentro del período sonoro, entendiendo que las del cine mudo son anteriores a su período de mayor éxito.

Comenzamos citando un artículo de Jordi López Luengo en el que encontramos una interesante propuesta sobre el origen del latin lover. Para este estudioso el hombre que debutaría ostentando este título sería el cómico francés Max Linder:

«Sin duda, hoy podemos constatar que Linder fue el precursor de la pasión que, a través del mundo del cinematógrafo, generaron los actores latinos en el imaginario popular, siendo, a su vez, el germen del que surgió el mito del latin lover (amante latino)». 320

Luengo establece el cine como contexto fundamental para convertir a un actor en latin lover y el segundo en ser catapultado a la fama por ser de nuevo el prototipo de amante latino fue Rodolfo Valentino. En 1921 este actor encarnará a Julio Desnoyers, un bailarín de tangos protagonista de la bohemia parisina en tiempos de la Gran Guerra. Valentino se convirtió también de alguna manera en un icono para los bailarines de tango, pero no para los realmente interesados en el género, puesto que su interpretación en las escenas de baile dejaba mucho que desear y presentaba un tango artificioso e impostado. Sus cualidades como apuesto gentleman y su prematura muerte ganaron la batalla a los más exquisitos conocedores del género. Durante mucho tiempo y aún actualmente, la salida americana ${ }^{321}$ fue siempre identificada con el atractivo Rodolfo Valentino.

320 Jordi Luengo López, «Ídolos populares de latina masculinidad. Valentino, Gardel y, otros 'violeteros modernistas'», Culturas Populares. Revista Electrónica 7 (2008): 8, acceso el 23 de abril de 2021, https://ebuah.uah.es/dspace/handle/10017/19793.

${ }^{321}$ La salida americana es un modo concreto de afrontar el arranque del tango danza. Se trata de una posición en la que la pareja, abrazada, avanza de frente con los brazos 
A pesar de su fama y su triunfo entre el público femenino como arquetipo latino de masculinidad, no nos interesa centrarnos en su figura en nuestro trabajo y es así porque nos parece que su aportación al género es meramente superficial. Además, nos limitamos a la masculinidad tal y como se entendía en el Río de la Plata y no sólo en la proyección que de un modo demasiado elaborado consiguió el cine de Hollywood con actores como Valentino. Sin embargo, sí nos interesa dejar constancia de la opinión de Jordi Luengo al proponer a Carlos Gardel como sucesor del actor:

«Carlos Gardel tomó el relevo al seductor italiano en ese rol de hombre ideal, ensueño constante para el colectivo femenino e idea reguladora para el masculino, y en él Hollywood también encontró otro filón para seguir potenciando, también a través del tango rioplatense, la figura del amante latino». ${ }^{322}$

Según la versión oficial hasta hace poco tiempo, el 11 de diciembre de 1890 nace en Toulouse Charles Romuald Gardes, conocido más tarde como Carlos Gardel. Sin embargo, cada vez cobra mayor relevancia la teoría que defiende que nació en Tacuarembó, Uruguay, y que no era hijo biológico de Berta Gardes, como se ha creído muchos años. De hecho, Charles Romuald Gardes y Carlos Gardel, no habrían sido la misma persona. No nos interesa detenernos en estos detalles de su biografía, pero sí dejar claro desde el principio que la figura del cantor de tango más famoso del mundo es aún hoy día objeto de investigaciones y de discusiones realmente apasionadas. En todo caso, pronto se mudó a Buenos Aires, creció en el barrio del Abasto y allí se convirtió en los años 20 en uno de los iconos más importantes de la ciudad y del país en general.

Gardel inventó una nueva manera de cantar el tango y protagonizó la etapa del tango canción que precisamente él había estrenado cantando Mi

extendidos y mirando al frente. En modos exagerados de ejecución los bailarines, además, juntan sus mejillas.

322 Jordi Luengo López, «Ídolos populares de latina masculinidad. Valentino, Gardel y, otros 'violeteros modernistas'». Culturas Populares. Revista Electrónica 7 (2008):19, acceso el 23 de abril de 2021, https://ebuah.uah.es/dspace/handle/10017/19793. 
noche triste de Pascual Contursi en el año 1917, aunque su verdadero éxito llegaría años más tarde.

Además de sus éxitos como cantor de tango, las dos circunstancias que, desde nuestro punto de vista, influyeron en su ascenso al mito fueron dos: las trágicas circunstancias de su muerte y su personalidad. Nos ocupamos en esta parte del trabajo especialmente de la segunda, aunque su muerte rondará siempre que hablemos de la consagración de su figura como una de las personalidades más ilustres de la República Argentina.

Gardel era un tipo afable, siempre sonriente, juerguista y, según cuentan también sus biógrafos, era un hombre muy preocupado por su aspecto físico. El escritor Federico Andahazi nos cuenta, por ejemplo, que:

«Gardel tenía una complexión robusta, por momentos excesiva; su tendencia a la obesidad - registrada en varias fotos- lo obligaba a someterse a constantes ejercicios físicos, dietas e incluso medicamentos.

Por otra parte, su pulcritud era proverbial. Desde el pelo, siempre engominado y brillante, hasta las uñas de los pies, todo en su aspecto estaba puntillosamente cuidado. La célebre sonrisa gardeliana, tan emblemática como la de La Gioconda, era el resultado de largas sesiones cosméticas que incluían rouge, maquillaje y retoques fotográficos. A donde fuera, siempre llevaba consigo un necessaire que incluía instrumentos para cada parte del cuerpo.

En cuanto a la ropa, su cuidado era tal que, aun los días en que no tenía función, podía cambiar de vestuario tres o cuatro veces. Iba a la peluquería en forma cotidiana para que los afeitaran, le hicieran fomentos y le aplicaran toalla caliente.» ${ }^{323}$

La leyenda habla de una adolescencia traviesa y algo delictiva por barrios y arrabales. Hasta se le atribuye un violento altercado, aunque parece no haber pruebas fehacientes de ello. Lo que está claro es que El francesito, como sus amigos lo llamaban, creció en un ambiente ciertamente marginal, lo

323 Federio Andahazi, «Los amores de Carlos Gardel», acceso el 20 de marzo de 2020, https://radiomitre.cienradios.com/los-amores-de-carlos-gardel-por-federico-andahazi/. 
que también contribuye a alimentar el mito de hombre hecho a sí mismo que llega a lo más alto partiendo de lo más bajo.

Pronto empezó a cantar en fiestas entre amigos y a destacar por su talento natural, pero cuando su madre y él se mudaron a la calle Corrientes, comenzó realmente su relación con la farándula. Bertha Gardés y su hijo vivieron un tiempo en esa mítica calle - ahora avenida - en una pensión cercana al teatro así que una de las ocupaciones de Bertha fue planchar ropa para algunos actores y ese ambiente fascinaba a Carlitos.

Por la influencia que sobre él tuvieron payadores como José Bettinoti o Gabino Ezeiza, Gardel se interesó en sus primeros años por las formas musicales criollas.

Es importante para nuestro trabajo la relación que Carlos Gardel tuvo con el arrabal y cómo la gente que lo habitaba pudo ejercer su influencia en la personalidad del cantante:

«...habría conocido inevitablemente a los malevos y compadres tan comunes en la proliferante metrópoli en el filo del siglo. Estos matones callejeros, con sus arrogantes alardes viriles, su inconfundible uniforme (botas bien lustradas, chambergo, pañuelo de seda anudado al cuello), sus muy preciados facones y pistolas, a menudo eran hostiles a los cantantes y otros artistas, pues los consideraban —y con buena razón— rivales ante la atención femenina». ${ }^{324}$

Esa vestimenta de los malevos de la que nos habla Collier en su biografía es la misma que emplean bailarines de tango de todo el mundo y de todas las épocas. Es indiscutible que esas figuras masculinas del arrabal ejercieron una gran influencia en el tango y que cantores como Carlos Gardel son fiel reflejo de ello. No hace falta más que ver fotografías del cantor y observar su aspecto físico, que tanto nos recuerda a los hombres de aquellos primeros tiempos del género. Gardel podría considerarse, desde nuestro punto de vista $-\mathrm{y}$ junto a otras figuras posteriores como Julio Sosa-, un

324 Simon Collier, Carlos Gardel. Su vida, su música, su época. (Buenos Aires: Plaza y Janés editores,1988). 
eslabón estético entre los compadritos de finales del XIX y principios del XX y los actuales bailarines de tango.

Es importante recordar que los compadritos y todos los demás tipos masculinos de la época forman parte de una historia altamente mitificada pero no por ello debemos prescindir de lo que nos cuenta. Esa mitología ha ayudado a llevar el tango por todo el mundo y a crear una imagen externa que, al menos por ahora, parece no ceder paso a otras. En 1918 Gardel descubrió el tango, alejado de la música criolla que interpretaba junto a José Razzano. Él ya era un gran bailarín de tango, pero encontró en el tango canción la oportunidad de su vida. Este fue el comienzo de su camino para convertirse en la gran figura de la historia del tango.

Desde los comienzos de los años veinte Gardel se convertiría en una figura admirada por hombres y mujeres. Muchas mujeres deseaban a este donjuán de cuya vida personal poco se sabía. Pero no sólo en Argentina sino también en Europa. Entre 1925 y finales de 1930 Gardel viajó dos veces a España y una a Francia. Allí consiguió ratificar su éxito, aunque todavía en esos tiempos sus centros de acción principales eran Argentina y Uruguay. También estaba extendiéndose su fama por toda Latinoamérica. En 1933 viajará a Nueva York donde también era muy conocido y donde filmaría con la Paramount sus últimas películas. Después de esta aventura cinematográfica en Estados Unidos nunca volvería a Buenos Aires.

La incursión de Carlos Gardel en el cine desde Flor de Durazno hasta Tango bar ofreció otra perspectiva del cantor. Ya no sólo se le escuchaba, ahora también se le veía. Eso ayudó a contribuir una estética gardeliana cuyo punto de partida serían las apariciones en prensa y sus actuaciones en directo pero que indiscutiblemente se ratificó con sus apariciones en la gran pantalla. Hablamos de Flor de Durazno porque fue la primera película que grabó, pero la imagen de Gardel a la que nos referimos se desarrolla sobre todo en las películas posteriores de las que hablaremos más adelante.

Uno de los grandes logros de Gardel fue conseguir una figura y unas maneras que no eran propias de un niño criado en la calle. Como ya dijimos en párrafos anteriores se preocupó mucho por su aspecto físico, su higiene, sus modales y consiguió realmente transmitir una imagen de dandi. 
Su figura, su modo de vestir y de peinarse fue tan determinante para la configuración de la imagen de artistas posteriores a él como su modo de cantar. En esa estética podemos ver reflejada la del antiguo compadrito, figura central del arrabal porteño de finales del XIX que vemos representada en el cuadro de El Chúcaro. Traje y sombrero adecuados en cada caso a la moda de su tiempo, pañuelo en el compadrito y corbata en Gardel. Se observa la misma preocupación por la apariencia en ambos casos. A través de esa imagen pública ambos enviaban un mensaje a la sociedad: el compadrito se identificaba como dueño del arrabal y el cantor se presentaba como primera figura del tango. El compadrito ${ }^{325}$, además, era un modelo de hombre valiente y viril que hacía gala de sus habilidades en la danza y, si hacía falta, con el cuchillo. Era su modo de hacerse respetar. Es muy importante recordar estos rasgos cuando pensamos en la imagen actual del tango.

Gardel se convirtió con los años en un icono de la masculinidad, su aspecto y su gesto en las fotografías que dieron la vuelta al mundo así lo mostraban, pero... ¿lo que conocemos de su vida nos permite justificar esa visión que el mundo tiene de él? ¿Estaban presentes en su día a día esos alardes de hombría que sí parece que mostraban los compadritos? Estos justificaban su virilidad a través de la valentía y de su pública relación con las mujeres. ¿Había algo de esto en Carlos Gardel? En este capítulo aludiremos a algunas de sus películas para saber qué imagen se quiso transmitir del cantor a través del cine y si esa imagen se corresponde con lo que él era en realidad o al menos, con lo que creemos que fue.

Antes de abordar el análisis de sus películas hemos querido navegar en la gran cantidad de artículos de prensa que se escribieron después de su muerte - concretamente entre 1935 y 2005 - para extraer un breve resumen de cómo lo describian los que lo conocieron bien y también los que simplemente siguieron su trayectoria.

\footnotetext{
${ }^{325}$ Debemos recordar que cuando hablamos del compadrito en cuanto a masculinidad se refiere estamos agrupando en su figura todas aquellas de las que hablamos al describir los roles masculinos como el guapo, el compadre o el malevo.
} 
La conclusión más inmediata que se puede extraer de la lectura de estos artículos es que Carlos Gardel era, para conocidos y no tan conocidos, un hombre simpático, bueno y leal. Su sonrisa y la ausencia de vanidad parece que son los rasgos que más definían su personalidad. Demostraba un amor incondicional hacia su madre y disfrutaba, sobre todo, entre amigos.

«... era un milagro de juventud permanente, de juventud pueril, expansiva, cordial, diáfana. Era todo él un abrazo tendido de amigo sin dobleces, ni complicaciones, llanote y sanote como su sonrisa y su carcajada». ${ }^{326}$

Destacan en estos artículos además su gran generosidad y lo importante que era para él la amistad. Vemos claramente estos rasgos en la lectura de varias anécdotas como esta que contaba José Razzano en 1945:

«Estaba enferma la hija de un común amigo, que no pasaba por buena situación económica. Carlos supo que debía ayudarlo. Para eso era amigo y podía. Me llamó una tarde de un día sábado para hablar del caso. Y convinimos en que mentiríamos al amigo. Yo iba a hablarle de una "fija" imperdible, en las carreras del día siguiente. No diría el nombre del caballo, porque era un secreto hasta momentos antes de la carrera. Pero como era un "dato" seguro, debía jugarse tantos pesos, con lo que salvaría su apuro. El amigo se resistía, pero al final aceptó. Carlos le prestaría, el dinero para la apuesta. Total, era por sólo unas horas. Al ganar el caballo, podría devolvérselo». ${ }^{327}$

Por supuesto no había tal apuesta, era solo una treta para ayudar a un amigo de un modo elegante y discreto. Este modo de proceder leal, discreto y generoso parece recordarnos a esa estricta moral que regía la vida del gaucho y que heredaron arquetipos como el guapo, el compadre y el compadrito. De nuevo tenemos que aludir a la propuesta de El Chúcaro y a esa evolución desde el gaucho al compadrito y todos los arquetipos masculinos de finales del XIX. Una prueba más que demuestra la veracidad

${ }^{326}$ Edmundo Guibourg, "Calle Corrientes» en Carlos Gardel y la prensa después de su muerte. 1935-1950 (Buenos aires: Ediciones Corregidor, 2014), 14.

327 «A diez años de la muerte de Carlos Gardel», Radiolandia n 899, (1945) en Carlos Gardel y la prensa después de su muerte. 1935-1950 (Buenos Aires: Ediciones Corregidor, 2014), 261. 
de su teoría es que todos estos tipos hacían gala -en mayor o menor medida - de dos o tres normas morales que defendían a ultranza: la lealtad, la valentía y la generosidad. De hecho, en uno de los artículos que hemos leído, el autor emplea la frase «hacer una gauchada» ${ }^{328}$ con el sentido de ser generoso. Por supuesto, utiliza esta expresión al hablar de Gardel.

Parece también que Gardel nunca hizo alarde de su relación con las mujeres, por ejemplo, siendo éste un rasgo que se podría observar en hombres que presumían de serlo. Leemos también que su voz era varonil, ¿por qué? ¿porque era grave? Tampoco nos aclaran este aspecto. Todos conocemos la voz de Gardel y ni siquiera se puede apreciar en su modo de cantar un rasgo chulesco o compadrón como podría ser el modo de Julio Sosa, por ejemplo, en el que sí podremos entrever una actitud con la que pretende hacer alarde de su virilidad.

En un artículo de junio de 1939 titulado «Cesar Ratti evoca la figura de Gardel» ${ }^{329}$ encontramos una curiosa alusión a su masculinidad. Lo define como "antidonjuán" y habla de su recato, de su pudor y dice de él no ser hombre de amoríos. Al contrario de lo que pudiera parecer en un principio, Otazú ve en estos rasgos una profunda masculinidad, quizá porque según él en cuestiones de amor Gardel "tallaba solo".

En otro artículo de 1939 su autor, Carlos Laguarda Visillac, insiste en emplear de un modo exagerado y artificial términos como «voz viril», «acento del varón», «voz viril y criolla», «corazón de varón, gaucho y compadre», «alma viril», «figura moral de varón criollo», «sentimientos de hombre», «voz virilmente sonora», etc. ${ }^{330}$ Parece que la intención fuera destacar esa faceta de exacerbada masculinidad que Gardel transmitió a través de su imagen y que el alarde de hombría fue un rasgo que se le quiso aplicar a alguien que

${ }^{328}$ Alfredo Varela, «El pianista de Gardel y de la Pavlova, recuerda...», Carlos Gardel y la prensa después de su muerte. 1935-1950. (Buenos Aires, Ediciones Corregidor, 2014), 251.

${ }^{329}$ Silvestre Otazú, "Cesar Ratti evoca la figura de Gardel», Carlos Gardel y la prensa después de su muerte. 1935-1950 (Buenos aires, Ediciones Corregidor, 2014), 192.

330 Laguarda Visillac, C. "Carlos Gardel símbolo de la patria rioplatense», Carlos Gardel y la prensa después de su muerte. 1935-1950, (Buenos Aires, Ediciones Corregidor, 2014), 100-105. 
se distinguió más bien por su discreción para con las mujeres y su afable carácter. Veamos por ejemplo cómo lo describe Mona Maris en una entrevista recogida en un artículo de 1985:

«Un hombre muy hombre, tenía una gran fuerza, un gran magnetismo. Era un gran amigo, muy generoso y por eso siempre estaba rodeado de muchachos y muchachas...». ${ }^{331}$

Entendemos qué significa ser un gran amigo, ser generoso, pero... ¿ser muy hombre? No sabemos —aunque podamos imaginarlo-a cuáles de sus cualidades se alude cuando se habla de Gardel en estos términos. Además, según María Capdevielle —nombre verdadero de la actriz- si la gente se acercaba a él era por ese carácter afable y cálido. Por tanto, esa virilidad que le atribuye tampoco sería un rasgo fundamental de su personalidad. De nuevo encontramos esa intención de encasillarlo en un tipo de hombre que ni era ni pretendió ser. Nos parece atisbar una especie de obligación de destacar la hombría de Gardel en muchos de los comentarios que lo describen.

En su relación con el cine esta hipótesis adquiere mayor consistencia y por ello hemos analizado parte de su incursión en el séptimo arte para mostrar de qué manera los guionistas, los directores y en general el ambiente que lo rodeaba quisieron hacer de él algo que no era.

Las películas que hemos tenido en cuenta en esta parte de nuestro trabajo para intentar discernir qué imagen quisieron exportar de Gardel al mundo a través del cine son, por orden cronológico, las siguientes: Flor de durazno (1917), Las luces de Buenos Aires (1931), Espérame (1932), Melodía de Arrabal (1933), Cuesta abajo (1934), El tango en Broadway (1934), El día que me quieras (1934) y Tango bar (1935). Además, se ha trabajado también sobre los cortos grabados en 1930 bajo el título de Encuadres.

${ }^{331}$ Héctor Lencina, «En los recuerdos de Mona Maris, Gardel era un hombre bien viril, pero algo tímido con las mujeres», Carlos Gardel y la prensa después de su muerte. 19502005 (Buenos Aires, Ediciones Corregidor, 2014), 343. 
Lo primero que observamos en estas apariciones cinematográficas es la evolución del cantante a la que aludíamos en párrafos anteriores y que tiene que ver con su preocupación por su aspecto y sus cuidadas maneras. Nada tiene que ver el casi irreconocible Carlos Gardel de Flor de durazno con el de cualquiera de las películas de la década de los 30. Pudiera ser que en esa primera película se dieran cuenta -él o quienes le rodeaban- de la importancia de su apariencia para consolidar su carrera.

Los argumentos de las películas que protagonizó no son complicados ni tienen mucha profundidad, pero desde la primera hasta la última se ve una evolución que tiene que ver con la del actor y cantante. Desde incluir folclore a mostrar solo tango, de un físico nada cuidado al aspecto repulido de un galán de cine. Es como si a través de sus películas pudiésemos entender su trayectoria no sólo profesional sino también personal. Es decir, el objetivo de estas películas fue mostrarle a él. No fue un actor escogido para transmitir un mensaje a través de una película sino una película creada para mostrar y dar a conocer - si no conocer, aumentar su fama - un personaje. O quizás un cantante de éxito en una pantalla para atraer público $\mathrm{y}$, con ello, hacer negocio. El cine fue una manera de triunfar y para ello crearon un personaje a medio camino entre la realidad y lo que creían que le ayudaría - a él y a quienes creaban y producían las películas- a triunfar. Había una cierta intención de que Gardel interpretara a Gardel.

Las tramas de las películas analizadas tienen que ver siempre con enredos románticos en los que el protagonista, o bien es un hombre con fama de mujeriego o bien salva a una mujer de algún malvado que la engaña. Además, se ponen en boca y en actitud de otros personajes sus cualidades de galán. Por ejemplo, en los primeros siete minutos de Espérame sus compañeros de reparto le tratan de galán, saluda a mujeres por la calle y una de ellas le pregunta si se acordará de ella. En estos escasos minutos ya está presentado el tipo de personaje al que interpreta.

También es importante el lenguaje empleado para autodefinirse. En Las luces de Buenos Aires escuchamos la manida frase "un hombre no debe llorar". De nuevo en Espérame en el minuto 44'23", manifestando Carlos Acuña su intención de defender a Rosario pase lo que pase, su amigo le dice 
"así hacen los hombres". En Melodía de arrabal Gardel tiene que recordar alrededor del minuto dieciséis que "los hombres pelean frente a frente", frase que nos recuerda a la moral estricta del gaucho a la hora de pelear que heredaron los guapos y compadres orilleros, y a la que hemos aludido al hablar de su generosidad.

Resulta evidente que la intención en todas las películas fue mostrar a Gardel como un hombre mujeriego, viril, en definitiva, un galán de cine. Pero, ¿era el cantante así? Si no lo era, ¿qué se pretendía con ello? Para nosotros está claro, aportarle al personaje una faceta con la que no contaba pero que le venía muy bien en su carrera hacia el éxito. El suyo y el de todos los que le rodeaban: productores, guionistas, actores, y otros muchos profesionales que ganaron mucho a su lado. Con esta forma de presentar a Gardel, se consolidaba la interpretación del tango desde un modelo de masculinidad ya descrito.

Gardel destacó siempre por ser un hombre amable, simpático y muy generoso. Fue discreto en su relación con las mujeres y su actitud ante los problemas solía ser dialogante y pacífica. Cuidó siempre de su madre y, cómo no, vivió historias de amor. No sabemos cuántas ni sus detalles y esto demuestra que nunca fue su intención alardear de su virilidad y de su éxito con el género femenino. De hecho, esta manera de comportarse hizo que muchos especularan acerca de su hombría y su condición heterosexual, sin entender a lo mejor que simplemente era un hombre discreto al que le gustaba disfrutar, principalmente, con sus amigos. Pero a lo mejor eso no encajaba en una época, un lugar y un género musical en el que la masculinidad era un rasgo fundamental. Pudiera ser por ello que, a través del cine, se pretendiera "completar" al artista más conocido del tango que, como algunos afirmaron siempre, era "macho". ¿Era y es "macho" el tango? En este trabajo demostramos - hablando desde muchas perspectivas diferentes- que, si no lo fue en una etapa primigenia, el relato que se hizo de su historia agregó los ingredientes que faltaban para que sí lo fuera y finalmente consiguieran que, al menos su imagen externa, lo pareciera. Lo que está claro es que la figura de Gardel, en especial su imagen, contribuyó a dar veracidad a esa teoría que 
muchos -entre otros Julio Sosa o el pianista y compositor Osvaldo Pugliese- defendieron siempre de que el tango era varón.

Por último, debemos hacernos otra pregunta, ¿consiguió Gardel interpretar al galán que todos pretendían? Nuestra respuesta es clara: no. Los personajes que interpreta son en el fondo inocentes, sus gestos son delicados y el empleo de su voz es suave y pocas veces se altera. En pocas palabras: poco creíble en términos de masculinidad de esa época. Sólo en El tango en Broadway consigue alejarse un poco de su personalidad real y mostrar una faceta de hombre ligón y mujeriego, pero para ello debe apoyarse el guión en comenzar con una escena en un apartamento de Nueva York con cuatro "amigas" a las que el cantante dedica el foxtrot Rubias de New York. De ahí en adelante nos va mostrando su faceta de gigoló. De nuevo y como veíamos en el comienzo de Espérame, el guión de la película describe al personaje en los primeros minutos valiéndose de escenas en las que se presenta de un modo demasiado evidente el tópico de hombre seductor. Tampoco en esa película lo consigue claramente pero el cine engloba un conjunto de tareas: guión, interpretación, dirección, producción, etc. Si Gardel no conseguía mostrarse como lo pretendía el equipo de la película, no les quedaría más remedio que echar mano de otros instrumentos como el argumento o los diálogos, por ejemplo.

En estos párrafos hemos tratado de defender dos ideas. La primera sería la utilización del cine para "completar" el "personaje" Carlos Gardel y exagerar su masculinidad, teniendo en cuenta los criterios de la época. La segunda idea sería que en las películas que filmó, al menos en la mayoría de ellas, el cantor no consiguió transmitir a través de su interpretación ese carácter de hombre seductor y extremadamente viril. $Y$ el motivo fue simplemente que Gardel se interpretaba a sí mismo, que los personajes no tenían mucha fuerza y no pudieron destacar por encima de su propia personalidad.

Entonces, ¿por qué decimos que Gardel fue un modelo de masculinidad si ni siquiera en sus películas pudo fingir serlo? La respuesta de nuevo es para nosotros clara: otra vez nos encontramos con un caso de mitificación tan típica no sólo de la historia del tango sino también de la historia 
de este cantante. Recordemos que aún en la actualidad los investigadores se "pelean" por saber dónde nació, dónde estudió, si Bertha Gardes era su madre, etc. Alrededor de su vida hay tanta leyenda acumulada que para alguien que no lo investigue a fondo es imposible discernir mito de realidad. O a lo mejor no nos interesa conocer la realidad porque la ficción es mucho más atractiva. Y esto nos recuerda a lo que Alejandro Grimson cuenta acerca de los mitos en su libro Mitomanías argentinas:

«En relación con los mitos, se han desarrollado distintas concepciones teóricas. La primera de ellas ha enfatizado la manera en que, a través del relato sagrado, una comunidad determinada ofrece explicaciones acerca de cómo es el mundo o cómo ha tenido origen una sociedad, una institución o un objeto. La segunda ha enfatizado el carácter tergiversador del mito: el relato popular como falsificación de una determinada realidad. La tercera vertiente ha señalado el carácter movilizador e interpelador de la mitología, su función creadora». ${ }^{332}$

Nosotros vemos a Gardel, además de como un gran cantor de tango, como una figura cuya personalidad demostró ser un verdadero motor estético. Eso unido a la capacidad de lo popular por permanecer en el imaginario sin necesidad de conocer la verdad completa. De los iconos populares importa lo que se ve en ellos, no lo que fueron.

Gardel, desgraciadamente, murió muy pronto y a partir de 1935 el mundo recibió como herencia su música, sus fotografías y sus películas. Lo que le gusta a la gente que admira a Gardel es escucharle cantar y en sus películas pueden disfrutar, además, de su amplia sonrisa. Consiguió ser un tipo elegante y muchos quisieron imitarlo. Se hicieron una idea de cómo había sido su vida, su relación con las mujeres. ¿Cómo no iba a ser un seductor un hombre con esa apariencia y esa voz? De hecho, con su figura y su muerte prematura ya estaba creado el mito.

Para algunos hombres sigue siendo referente de masculinidad y eso ha influido en la estética de los bailarines del tango y en el modo en el que el

332 Alejandro Grimson, Mitomanías argentinas. Cómo hablamos de nosotros mismos. (Buenos Aires, Siglo XXI editores, 2013), 19. 
mundo ve todo lo relacionado con su música. Pero no todo estilo de tango sino el más internacional, el que es igual allí donde lo bailen, por lejos que sea. Hablamos del tango salón y del tango fantasía, aquellos que más relación tienen con las imágenes que actualmente encontramos por todo el mundo y que aluden a esta danza.

Para concluir, podemos afirmar que la imagen popularizada de Carlos Gardel fue uno de los eslabones estéticos que consiguieron dar continuidad a un camino trazado entre la Buenos Aires del s. XIX y el mundo actual. Un paso más en el camino iniciado por los compadritos y otros personajes del arrabal que tanto influyeron en la creación de la coreografía y de la imagen pública del tango, del gesto de los bailarines y su vestimenta y que tanto tiene que ver con la masculinidad, un rasgo muy apreciado durante décadas.

\subsubsection{Julio Sosa.}

Julio María Sosa Venturini nació en Las Piedras, Uruguay, el 2 de febrero de 1926. Vivió una infancia complicada en una familia con muchas necesidades. A pesar de tener que emplearse en diversos oficios, desde muy joven siempre tuvo claro que quería dedicarse a la canción. Sin embargo, y aunque se presentaba a todo concurso que se celebrara, en Montevideo nunca logró alcanzar el éxito. Con 23 años se muda a Buenos Aires y en muy poco tiempo consiguió lanzar su carrera y convertirse en un famoso cantor de tangos en una época difícil para el género.

Algunos pretendieron hacer del llamado Varón del tango un Gardel, incluso le criticaron porque casi la mitad de su repertorio pertenecía al Zorzal, pero él mismo en un reportaje de Luis González para la Radio del pueblo en el año 1964 se defendía de estos reproches. Explicaba en esta entrevista que efectivamente él había tomado parte del repertorio gardeliano pero que nunca intentó imitar al cantor ${ }^{333}$. Como veremos, hay cierto paralelismo en las trayectorias vitales de ambos cantores, pero estéticamente representaron dos estilos muy diferentes.

333 Véase en Anexos una entrevista a Julio Sosa por el periodista Luis González para Radio El Pueblo en el año 1964. 
La juventud había conocido el rock, el twist y otros géneros que globalizaron el gusto musical en todo el mundo. El tango ya no les interesaba. En una escena de la única película que hizo el cantante se representa perfectamente este conflicto entre géneros y generaciones. Se titula Buenas noches, Buenos Aires ${ }^{334}$ y alrededor del minuto cuarenta Julio Sosa y Beba Bidart le demuestran a un grupo de jóvenes que ni el twist, ni el mambo podrán superar jamás a la milonga. Es en este ambiente en el que el cantante triunfa y consigue hacerse un hueco como uno de los mejores del género. Empezó cantando en el café Los Andes donde alguien le escuchó y gracias a ello en poco tiempo estaba trabajando con la orquesta de Armando Pontier. Allí compartía micrófono con Alberto Podestá, quien lo reconoce como uno de los mejores amigos que ha tenido en su vida. Él mismo en una emisión especial del programa Siglo XX Cambalache en la cadena argentina TELEFE (Televisión Federal) habla de cómo la llegada de Julio Sosa a la orquesta y en general al mundo del tango fue algo muy novedoso. La novedad que ofrecía Sosa con respecto a otros cantantes era su manera de interpretar: movía los brazos, gesticulaba mucho, era casi como un actor. $Y$ es que uno de los rasgos que más lo diferenciaban era su carisma, su fuerte carácter $\mathrm{y}$, en general, su personalidad. Ese talante, su manera de hablar de la figura masculina, parte de su repertorio y la impresión que causaba en quienes lo veían y escuchaban nos darán las claves para entender por qué consideramos que Julio Sosa es otro de los eslabones de esa cadena que parte de los roles masculinos del XIX y llega a los bailarines de tango actuales.

En el año 1960 Sosa se desvincula de la orquesta de Pontier para empezar su carrera como solista. En esta nueva etapa contará con Leopoldo Federico y su orquesta con los que trabajará hasta el fatal accidente en el que en 1964 encontró la muerte.

Además de la música Julio Sosa tenía otra gran afición: la poesía. La editorial Logos publicó el libro de poemas Dos horas antes del alba que se agotó poco después de su muerte y nunca fue reeditado. En este libro el cantante da muestras de un gran dolor existencial que abarca todas las

\footnotetext{
${ }^{334}$ Hugo del Carril, Buenas noches, buenos aires, (Argentina: DASA, 1964).
} 
facetas de su vida y que ratifica las opiniones de muchos sobre una profunda melancolía que contrastaba con su carácter alegre y desprendido. De esto nos hablaba un artículo de La Nación en febrero de 2001:

«En la personalidad de Julio Sosa anidaba un ser disconforme, que a menudo era visitado por la angustia. Sin duda pesaba sobre él una infancia con un padre analfabeto y una madre que se desempeñaba como sirvienta. Por eso un día pudo confesar "Yo me llamo fracaso". Muchos pudieron descubrir en él a un muchacho sombrío, a veces triste, que contrastaba con una estampa exteriorizada de hombre seguro de sí mismo, de displicente soberbia y cancherismo». ${ }^{335}$

Pero lo cierto es que Julio Sosa fue, para la mayoría de los que le conocieron o le admiraron un modelo no sólo como artista, sino también como hombre. Sus gestos, su voz grave - como la de muchos, por otra parte- y sus alardes de varón lo erigieron como un adalid de la masculinidad como rasgo fundamental del hombre argentino hasta una determinada época, como veíamos en la película Buenas noches, Buenos Aires.

A continuación, vamos a repasar algunas de las frases que se emplearon para definirlo:

«Así fue imponiéndose su estilo; estilo varonil, pero sin ínfulas, sin las bravuconadas canoras de Hugo del Carril, pero de estremecida dramaticidad». 336

«¡Me encanta la voz, me emociona ese timbre profundamente varonil! Pienso que el "Varón del Tango" está muy bien puesto». ${ }^{337}$

En prácticamente todos los textos que hemos leído sobre Sosa, así como en las entrevistas o reportajes de los medios de comunicación, quienes

${ }^{335}$ René Vargas Vera, «Ayer habría cumplido 75 años. Julio Sosa dejó su marca en el tango», La Nación (2001), acceso el 15 de marzo de 2020, https://www.lanacion.com.ar/espectaculos/julio-sosa-dejo-su-marca-en-el-tango-nid50913/.

${ }^{336}$ «El Varón del tango. Julio Sosa y una historia llena de interrogantes. Entrevista a Anna Magnabosco (docente, dramaturga y narradora)», La Onda digital, acceso el 8 de abril de 2021, https://www.laondadigital.uy/LaOnda2/627/A3.htm.

$337 \mathrm{lbidem}$. 
se refieren a él hablan siempre emplean este vocabulario: hombría, virilidad, varón, etc. Parece que era su carta de presentación.

Y esto no sólo tenía que ver son sus maneras y sus gestos exagerados sino también con su opinión sobre cómo debería ser el tango. O más bien podríamos decir que tenía tan claro que el tango y, en general el hombre argentino, debía hacer alarde de su masculinidad y su hombría que lo interiorizó y lo sacaba a relucir en cada gesto, en cada movimiento y, cómo no, en cada interpretación. En una entrevista en 1958 Sosa se queja del auge de los nuevos géneros como el twist y pone el foco en la hombría o, más bien, la ausencia de hombría:

«Antes ser argentino era símbolo de virilidad y hombría...solo nos falta que nos pintemos los labios para salir a la calle». ${ }^{338}$

También hemos escuchado en esa misma entrevista cómo el presentador le transmite una petición que a su juicio proviene del pueblo: que incluya en su repertorio temas como Por qué canto así. Según el locutor este tipo de tango es el que más éxito tiene entre sus seguidores y lo que le reclaman. Detengámonos un momento en la letra de este tango.

Por qué canto así fue compuesto por José Razzano y Celedonio Flores en 1947 y El Varón del tango recitaba su letra sobre el famoso tema de Gerardo Matos Rodríguez, La comparsita. Al recitar este texto, el cantor parece estar contando su historia, su pobre infancia, y es especialmente representativa de su modo de afrontar el tango la siguiente estrofa:

«Cuando el hambre viene

y yo me hice en tangos porque

porque el tango es macho!

porque el tango es fuerte!». ${ }^{339}$

Además, nos interesa mucho lo que dice Sosa al comenzar esta intervención radiofónica. Afirma que no le gusta el tango de farolito, que

339 Gerardo Matos Rodríguez, «La comparsita», cfr. TTL, acceso el 17 de junio de 2021, https://www.todotango.com/musica/tema/25/La-cumparsita- [Matos-Rodriguez]/. 
prefiere el de Manzi o Discépolo. Estos dos compositores nos llevan a la Edad de Oro del tango, esa en la que, según concluíamos al analizar las letras, tanto se contribuyó a configurar esos lugares mitológicos donde el hombre macho y varón era protagonista.

También podemos asociar muchos de sus comportamientos a ese alarde de masculinidad como fue, por ejemplo, su gusto desmedido por la velocidad. Era una muestra más de valentía, de no tener miedo a nada o de, en caso de tenerlo, ocultarlo.

Sin embargo, al profundizar en la figura de este artista encontramos también una faceta que lo muestra como una persona introvertida, sentimental y hasta atormentada. Estos rasgos los vemos reflejados en su libro de poemas Dos horas antes del alba. No hay más que leer parte de las preliminares Palabras del autor para darse cuenta de esto:

«Poder escribir ha sido siempre una válvula que alivió la tensión de volcánicos estados anímicos o mortales depresiones morales.

Cuando mi alma a punto de asfixiarse o mi corazón a punto de estallar bajo el mandato de la alegría o el lapidario peso del dolor (más por éste que por aquellos), necesitó de la sangría que la aliviara, mi pluma obró el milagro de devolverme la paz, me enseñó a enfrentar la vida con más valor y a mirar a mis semejantes con ojos más buenos». ${ }^{340}$

Es evidente que en la vida de este viril cantor hubo mucho sufrimiento y que su vida pública, sus gestos y su talante varonil le ayudaron a crear una imagen de fuerza y coraje que probablemente solo era real en su día a día social, nada que ver con sus debilidades y su sufrimiento interior.

En cuanto al repertorio que este cantante escogió para llevar al escenario debemos ponerlo en relación con lo que hemos expuesto en el capítulo anterior acerca de las letras de tango. Podemos afirmar que Julio Sosa seleccionó los tangos de la Edad de Oro, que entre los elegidos había muchos temas de Celedonio Flores, Enrique Cadícamo o Manuel Romero -

340 Julio Sosa, Dos horas antes del alba (Buenos Aires: Editorial Logos, 1960). 
letristas de los que hemos hablado mucho en este trabajo- y sobre todo de Carlos Gardel, pero muy pocos de estos podemos encontrarlos entre esos casi quinientos tangos en los que encontrábamos un exagerado alarde de masculinidad.

Julio Sosa también compuso un tango, Seis años, cuya música fue compuesta por Edelmiro D'Amario. En este texto vemos al Sosa más romántico y sentimental mostrando miedo y pudor de que, en un encuentro casual, un antiguo - aunque latente- amor le reconozca y descubra que al volver a verla después de seis años se ha despertado en él toda la pasión de antaño.

Por otro lado, encontramos que la historia de este cantante que popularmente se conoce y se cuenta tiene mucho que ver con la historia personal de Carlos Gardel. Al igual que el Zorzal Criollo, se cuenta que Sosa fue hijo de Lisandro Carámbula, un hombre muy poderoso de Las Piedras, lugar de nacimiento del músico. El imaginario popular cuenta que una criada menor de edad dio a luz un bebé y que Carámbula tapó el escándalo organizando una boda y regalándole una casa modesta como obsequio para evitar habladurías. Es prácticamente la misma historia que la poetisa e investigadora Martina Iñiguez nos contó en una entrevista realizada en Buenos Aires y que posteriormente fue transmitida radiofónicamente en el programa Alevare, de Radiouniversidad de Salamanca ${ }^{341}$. Martina nos contó la siguiente historia que resumimos sobre el verdadero origen de Carlos Gardel: parece que el mejor cantante de tangos de todos los tiempos nació en Tacuarembó fruto de una clandestina y posiblemente incestuosa relación entre el militar y caudillo político uruguayo Carlos Escayola con una de sus cuñadas que tenía, en ese momento, solo trece años. Al igual que sucedía en el caso de Sosa, el nacimiento se intentó tapar creando para este niño una nueva vida con la que para todos los que hemos leído sobre su vida fue su madre oficialmente, Bertha Gardes. Bertha Gardes llegó durante ese tiempo a Tacuarembó a trabajar como planchadora y allí se quedó embarazada

${ }^{341}$ Martina Iñíguez, entrevista por Laura Alonso, Alevare, Radiousal, podcast, 27 de febrero de 2021, acceso el 20 de junio de 2021, http://radio.usal.es/programa/alevare/. 
también en circunstancias complicadas y por ello decidió marcharse a Toulouse a tener a su hijo. Ese hecho fue el que aprovechó la familia Escayola para enviar a Carlitos, que ya tenía seis años, a vivir con esta mujer que, a partir de ese momento, sería su madre oficialmente. Posteriormente viajarían a Buenos Aires y allí comenzaría la historia de Gardel conocida por todos.

Es cuando menos curioso que los dos iconos del tango hayan compartido una historia popular - no es nuestro cometido demostrar si es cierta o no- tan parecida. Y lo que realmente nos interesa es que, sean o no ciertas estas historias, siguen aportando ingredientes para que el mundo entero se sienta atraído por sus protagonistas. No importa para nosotros cuáles serían los motivos de fabular alrededor de la vida de dos importantes cantantes en caso de que no fuera cierto lo que se cuenta. Lo que nos importa es que todas estas intrigas y enredos contribuyen a aumentar el interés sobre ellos. $Y$ con ese interés llega la influencia que estéticamente ejercieron en la danza del tango. Desde finales del XIX se fueron creando personajes y mitos a quienes muchos bailarines intentan remedar en sus actuaciones, cuando bailan en un encuentro social o simplemente cuando en familia disfrutan al bailar un tango. 


\section{CONCLUSIONES}

Julio Sosa aseguraba que el tango es macho. Osvaldo Pugliese decía que el bandoneón tenía un timbre muy varonil. El cine, la radio y en general el mundo entero intentaron hacer de Carlos Gardel un icono masculino, el Don Juan del tango. Casi quinientas letras del tango de las décadas de 1920 y 1930 nos convencieron de que el género popular rioplatense se había gestado entre compadritos valientes que alardeaban de sus conquistas amorosas y de su coraje. Los intelectuales más relevantes de la literatura argentina fabularon con este mundo legendario - aunque "basado en hechos reales"- en el que una población mayoritariamente masculina habitaba los suburbios de ambas orillas del Río de la Plata.

Lo que recoge el párrafo anterior podría ser un muy breve resumen de los pasos que hemos dado en el desarrollo de esta Tesis Doctoral. Hemos recorrido, por tanto, en este trabajo, un camino que comienza a finales del siglo XIX y llega al siglo XXI, haciendo paradas en la década de los veinte y treinta, -la Edad de Oro del tango, cuyo mayor exponente fue Carlos Gardel-, en la década de los sesenta con la figura de Julio Sosa, para terminar en el tango que se baila actualmente en todo el mundo.

Lo que hemos pretendido en este trabajo es mostrar el hilo que une todas esas diferentes etapas y que le aporta al tango unos rasgos que lo distinguen de cualquier otro tipo de música popular. Para ello hemos partido de los diferentes modos de contar la historia de este género musical y, de una manera muy particular, del cuadro coreográfico de El Chúcaro titulado Del gaucho al compadrito y hemos escogido este documento por dos motivos. El primero es que Santiago Ayala, el Chúcaro, además de haber sido uno de los más importantes —si no el más importante- bailarín folclórico de Argentina, era un gran estudioso de todas las danzas del país, incluido el tango. Ya hemos dicho que no era milonguero y no frecuentaba los ambientes de tango, pero conocía perfectamente la danza. El segundo motivo por el que hemos establecido esta coreografía como marco de nuestra investigación es que se basa en la transición entre dos figuras masculinas, el gaucho y el compadrito. Nuestro principal objetivo era demostrar que lo que verdaderamente hace del tango danza un género absolutamente carismático es la masculinidad que 
impregna sus gestos, su vestimenta, muchas de sus letras y también muchas de sus interpretaciones. Por ello fue muy importante para nosotros hallar esta propuesta que, en primer lugar, apoyaba nuestra tesis de que la figura masculina, o la visión que se tenía de ella, fue fundamental en el desarrollo estético del tango. Además, nos resultó una herramienta muy útil para organizar el material con el que queríamos configurar nuestro itinerario estético.

El Chúcaro nos proporcionó la primera piedra, ya que él propuso al compadrito como protagonista del tango y al gaucho como su precedente. Pero nosotros sospechábamos y hemos podido comprobar que no solo los compadritos bailaban el tango, que los niños bien también lo hacían y que al tango se puede llegar por muchos caminos, no sólo a través de la danza, no sólo a través del suburbio y, por supuesto, no solo a través del compadrito.

Entonces nos formulamos dos preguntas: ¿por qué ese modo de vestir, ese remedar a los hombres del XIX y ese alarde de hombría que destaca en actuaciones, carteles y películas aún hoy en día? ¿Cuándo se empezó a gestar esa manera de entender el tango?

Para responder a estas preguntas escogimos las fuentes que a nuestro criterio podían aportarnos información relevante y en ellas buscamos muestras de masculinidad: actitudes, gestos, imágenes, leyendas, vocabulario. Esa información nos iba permitiendo establecer algunos ámbitos concretos en los que poder profundizar posteriormente en nuestra investigación: el tango danza de los comienzos, las letras de la Edad de Oro del tango, los textos de Borges o Carriego, Carlos Gardel y, por último, Julio Sosa. Decidimos desde el primer momento, por cuestiones metodológicas y de enfoque, dejar fuera otras fuentes como el cine o el teatro en las que es posible que también habríamos encontrado información interesante para nuestro estudio. Solamente al hablar de Gardel y por considerarlo imprescindible tuvimos en cuenta las fuentes cinematográficas y analizamos el tratamiento de su figura en las películas que filmó durante su período de mayor éxito. Adentrarnos en el análisis del tango en el cine y, sobre todo, en el teatro, habría sobrepasado los límites y los objetivos de este trabajo. 
Pensamos que son dos ámbitos de estudio que requerirían un trabajo independiente.

Fue también muy importante la configuración del Estado de la Cuestión y no sólo para presentar sistemáticamente los estudios académicos relacionados con nuestro tema sino como objeto de nuestro análisis puesto que hemos concedido mucha importancia en nuestra investigación a las diversas formas como ha sido contada la historia del tango. El recorrido por los paradigmas dominantes de interpretación de lo que ha sido el tango ha supuesto otro de los pilares fundamentales, junto con la interpretación que se desprende del espectáculo de El Chúcaro. Esta nos ha permitido construir nuestro propio relato que es, sin duda, alternativo respecto a los anteriores.

Pues bien, el análisis de todas las fuentes primarias y secundarias relacionadas con los ámbitos descritos nos permite ahora establecer una serie de conclusiones que exponemos a continuación.

En primer lugar, el tango nace en un momento de cambio fundamental en la historia argentina y uruguaya. Se trata del paso del mundo rural al urbano, de la creación del Estado moderno basado, fundamentalmente, en el modelo agroexportador. Este cambio favorece la aparición de un grupo social a medio camino entre esos dos modelos de sociedad que se asienta en los suburbios de las ciudades y que será poblado, en gran medida, por inmigrantes. El importante proceso inmigratorio convierte las márgenes del Río de la Plata en un territorio eminentemente masculino.

En segundo lugar, antes de la aparición de la primera Historia del tango, la de los hermanos Bates, ya se ha creado una literatura que describe perfectamente cómo debe comportarse un hombre que se precie de serlo. A partir de ese momento, en la literatura abundarán términos como "varonil", "viril" y "hombría" que se emplearán no sólo para describir actitudes en los hombres sino también en lugares, instrumentos y, en general, el tango. La literatura - y sus representantes - también tendrá este género musical como eje temático principal en la mayoría de los casos o solo como referente en muchas ocasiones, por lo que masculinidad y tango se unen, de nuevo, en páginas importantes de la historia. 
Además, durante la Edad de Oro y a través de muchas letras de tango, se creó todo un imaginario basado en esas orillas y arrabales de los que hablábamos en párrafos anteriores. El protagonista de estas historias iba a ser el compadrito y muy probablemente los autores de estos textos se habrían visto influidos por la literatura anterior y contemporánea en la que este nuevo sujeto histórico y literario fue habitual. Se crea a partir de entonces lo que podríamos denominar como una estética arrabalera que nace como marcadamente masculina. Para la creación de esta estética fue también muy importante la inclusión de términos del habla popular porteña: el lunfardo.

Concluimos también que el estilo de tango en el que mejor podemos ver reflejada esta estética no es, como cabría esperar, el de la Guardia Vieja (desde los orígenes hasta la década de 1920). Y esto se debe a que el relato se crea años después. Cuando el tango se bailaba en reuniones populares como las romerías españolas o más adelante en los populares patios del conventillo —según los testimonios que tenemos-, aún no se había creado esta mitología y por lo tanto en sus movimientos y en su estética aún no se aprecia esa exacerbada masculinidad que contrasta con la figura femenina. En el tango primigenio una pareja bailaba para divertirse, para festejar, es decir, que el baile no era aún un elemento jactancioso y mucho menos el protagonista de una mitificada narración. Lo veíamos en las imágenes de estos encuentros que hallamos en la revista Caras y Caretas. Será en los años ochenta del siglo XX, cuando tiene lugar el resurgir del tango a través de la danza, que se recupera esa leyenda del compadrito y se incluye en la estética de los bailarines. En esta época se establecen los estilos de tango que conocemos actualmente con patrones que nos permiten diferenciar claramente uno de otro. Pero en la configuración de estos estilos, fundamentalmente el tango salón y el tango escenario, influyó mucho todo lo que desde principios del siglo XX se contó acerca del tango y lo que para sus narradores habían sido sus protagonistas, los compadritos. La narración de los orígenes fue fundamental para establecer la imagen posterior y dominante del tango, especialmente en su desarrollo como danza.

Finalmente, para que los bailarines de los años ochenta incluyeran esa estética en sus movimientos y en su vestuario hicieron falta referencias 
concretas a hombres concretos y en este punto hemos destacado a las que, sin duda son las dos voces más populares - junto con Roberto Goyenechedel tango: Carlos Gardel y Julio Sosa.

Como es sabido, Carlos Gardel es la referencia principal para cualquiera que se acerque al tango y, como hemos podido concluir al analizar su figura, el mito que se creó alrededor de su vida lo convirtió en un icono masculino. Lo que conocemos de él por quienes lo conocieron nos hace pensar que era un hombre bueno, sonriente y amigo de sus amigos. En ningún momento lo que conocemos sobre él nos haría pensar en el prototipo de hombre mujeriego y jactancioso que nos quieren presentar en sus películas, por ejemplo. El cine quiso hacer de él un Rodolfo Valentino rioplatense, pero ni siquiera en la ficción El Zorzal consiguió dar esa imagen. Su repentina muerte, los tangos que interpretaba y las infinitas imágenes que conservamos de él fueron los ingredientes de su leyenda como icono varonil. Tal y como hemos mostrado en nuestro trabajo, nada que ver con la realidad.

Julio Sosa, en cambio, siempre fue un hombre de talante más agresivo. Hablaba siempre con franqueza y no siempre mucha diplomacia, era un amante de la velocidad, tenía relaciones tormentosas con mujeres y en sus intervenciones hablaba del hombre argentino como ejemplo de macho. Se quejaba de que los nuevos géneros feminizaban a los hombres y se avergonzaba de ello. Quienes lo conocieron y trabajaron con él destacaron sus gestos y en general su interpretación como el aporte original que había traído al tango. Su aspecto y su voz fueron siempre descritas como exageradamente varoniles, aunque lo que nosotros vemos es un hombre de voz grave, como tantos, para quien era muy importante dejar claro que era precisamente eso, un hombre.

La conclusión final de este trabajo es que la masculinidad fue un ingrediente que se añadió al tango a través de un cúmulo de mitos y leyendas. A pesar de intentos como los de aquellos historiadores que intentan explicar los hechos tal y como ocurrieron en realidad, la leyenda ha superado a la historia. Es más, la leyenda es la responsable de que el tango se baile, actualmente, en todo el mundo y a ello han contribuido bailarines, literatos, cantantes, periodistas y letristas. 
Nunca nos interesó saber dónde, cómo y cuándo se bailó o se cantó el primer tango. Nuestra intención era saber por qué la estética de esta música popular es la que es. Creemos haber podido demostrarlo teniendo en cuenta nuestras fuentes, aunque, como ya hemos apuntado, hay muchas más. Esta investigación muestra, por último, la riqueza de posibilidades que sigue albergando el tango de cara a investigaciones ulteriores. Algunas de esas posibilidades han quedado apuntadas en nuestro trabajo sin que, por razones de espacio, de tiempo y de cumplimiento de objetivos, hayamos podido desarrollarlas. Aguardan, por tanto, muchas investigaciones para ser abordadas tanto desde las perspectivas que proponemos como desde otras que puedan basarse en las mismas fuentes o en otras por descubrir. Nos referimos no solo al tango sino también a la masculinidad y a la vinculación de ambos conceptos. La influencia de la imagen pública del hombre en el género porteño puede y debe -en nuestra opinión — ser analizada en otros ámbitos que nosotros no hemos podido trabajar, como ya hemos dicho, por cuestiones de tiempo y espacio. Nos referimos, por ejemplo, a las formas teatrales, a la cinematografía o otras figuras relevantes del género distintas a las aquí presentadas.

Nos gustaría ahora dejar constancia de la importancia que tiene este trabajo en el ámbito académico. En primer lugar, consideramos que nuestro estudio es absolutamente original tanto en lo que se refiere a la elección del tema como en el modo de afrontar las fuentes consultadas. Lo habitual es que los trabajos que tratan de alguna manera la masculinidad en el tango lo hagan desde el punto de vista de género y no de la estética; es decir, se estudia el comportamiento masculino en relación con el femenino desde un punto de vista sociológico. Además, el estudio de lo viril enfocado en la danza es absolutamente novedoso. También queremos destacar que nuestro trabajo es pionero porque recoge una síntesis de la historiografía de este género hasta el momento dejando claros los diferentes caminos que cada investigador $-\mathrm{y}$ quienes les siguieron - han ido tomando y los diferentes puntos de vista desde los que se ha afrontado la ardua tarea de analizar las fuentes que nos hablan del tango. 
En segundo lugar, para nosotros muchas de las fuentes secundarias pasan a ser consideradas como primarias, ya que el hecho de hablar del tango de un modo u otro es, a nuestro criterio, fundamental a la hora de entender de dónde procede la imagen del tango por la que es universalmente conocido. Por ello, un aspecto que aporta a nuestra tesis parte de esa originalidad de la que hablábamos en párrafos anteriores tiene que ver con el tratamiento del Estado de la Cuestión. En la mayoría de los trabajos de investigación, sean del nivel que sean, este capítulo sirve para exponer lo ya estudiado sobre el tema que se va a tratar y así establecer un punto de partida académico. Para nosotros este capítulo es algo más que eso, forma parte de lo que consideramos cuerpo del trabajo y los estudios allí expuestos son, como ya hemos dicho, fuentes primarias. Esto es así porque nuestra tesis defiende que la estética de la danza tango está absolutamente determinada por la narración de la historia del tango y de sus supuestos protagonistas.

En cuanto a las fuentes debemos decir también que ha sido determinante para este trabajo la consulta de fuentes populares como artículos, entrevistas, conversaciones radiofónicas y otras manifestaciones cuyo principal objetivo no era el registro de un estudio académico sino el entretenimiento o la divulgación de un modo absolutamente popular. Es por todo esto que consideramos que destaca en este trabajo un empleo original de las fuentes.

Debemos también poner el foco, asimismo, en el trabajo de lectura de las más de nueve mil letras de tango registradas en uno de los sitios web de referencia en el estudio del tango. Esta tarea fue larga y tediosa pero, quizás, la más fructífera de las que hemos abordado en este tiempo de investigación. La inmersión en los textos, en las intenciones de los autores, en su vocabulario y el análisis posterior de la selección que realizamos teniendo en cuenta el tema de nuestro trabajo es, en nuestra opinión, una experiencia obligada para quien quiera entender el género tango.

También fue para nosotros muy esclarecedora e imprescindible para comprender la sociedad rioplatense durante el cambio del siglo XIX al XX la consulta de la revista satírica Caras y Caretas. En concreto leímos los ochocientos cuarenta y nueve primeros números semanales comprendidos 
entre 1898 y 1914 . En estos ejemplares pudimos ver reflejada la cotidianeidad de Buenos Aires en aquellos años, cómo se narraban los acontecimientos nacionales e internacionales $y$, en definitiva, un modo de entender la vida. Conocimos cuáles eran los bailes de moda y entendimos que cuando esta revista comenzó su andadura a finales del siglo XIX el tango ya era algo conocido y en cierta manera superado. Aprendimos quién era el compadrito, cómo vestía, cómo hablaba y qué tipo de narraciones protagonizaba. Nos ayudó, además, a contrastar cierta información referente a cómo se bailaba el tango por aquellos años.

Hemos querido también dejar constancia del estado actual de las investigaciones. Además de los investigadores de los que hemos hablado, existe actualmente un grupo de personas vinculados con el tango desde diferentes puntos de vista - bailarines, profesores, coleccionistas, etc.- que intentan desmentir mitos referentes a la historia del tango. El resultado de sus análisis aún no está publicado, pero actualmente realizan una importante labor de divulgación a través de redes sociales y estamos seguros de que llegarán a tomar forma de interesantes publicaciones.

En definitiva, presentamos aquí un trabajo novedoso, aunque también, sin duda, con muchas carencias. A pesar de ello estamos seguros de que con nuestra investigación contribuimos a conocer mejor el tango y a su consolidación como objeto de estudio, en este caso, de la Estética. 


\section{Apéndice $A$}

Selección de letras de tango y poemas lunfardos, ordenadas alfabéticamente, que contienen palabras o expresiones relacionadas con la masculinidad. Todos ellos están disponibles en la web Todo Tango en «Letras».

\section{TANGOS:}

- A Beba Bidart, Alberto Uemurla.

- A Carlitos Gardel, Lopecito.

- A Carlos Gardel, Armando Villador.

- A diez centavos la pieza, Santiago Adamini.

- A la edad de los varones, Otilia Da Veiga.

- A la luz del candil, Julio Navarrine.1927.

- A mí me copa el tango, Renée Carmen Díaz. 1982.

- A mi padre, Héctor Marcó. 1955.

- A Rosalía, Luis Alposta.

- Acabala, Ángel Wilder.

- Achacao, Álvaro Yunque.

- Actualidad porteña, Jesús Fernández Blanco.

- Adelantá el reloj, Antonio Benedicto y Héctor Lupotto.

- Adiós a Arolas, Enrique Carícamo. 1949.

- Adiós arrabal, Carlos Lenzi. 1930.

- Adiós mi barrio, Víctor Soliño. 1930.

- Aguas turbias: 1942. Francisco Gorrindo.

- Aguja brava, Eduardo Giorlandini.

- Al compás de un tango, Óscar Rubens. 1942.

- Al gran campeón, Rafael Lauría. 1954.

- Al tango lo canto así, Tita Merello.

- Alegre bacán, Carlos Faenz.

- Alergia, Héctor Gagliardi. 1949

- Alguien le dice al tango, Borges.

- Allá en el bajo, Ismael Aguilar y Gerónimo Martinelli Massa. 1926.

- Alma de malevo, 
- Almacén de la Parda Gloria, Alberto Uemurla.

- Amablemente, Iván Díez.

- Amasijo habitual, Carlos de la Púa.

- Apache, Luis Rubistein.

- Aprender, Marta Pizzo.

- Aquí hace falta un tango, Teddy Peiró. 1950.

- Aquí me pongo a cantar, Ángel Greco.

- Argentina campeón, José Libertella, Aquiles Roggero, Orlando Trípodi, Horacio Casares, Edmundo Baya, Héctor Léttera, Felipe Ricciardi, Ítalo Ponti, José Paz, Carlos Taverna.

- Arrabalera, Cátulo Castillo. 1950.

- Arrabalero, Eduardo Calvo. 1927.

- Así es el tango, Homero Manzi.

- Así fui yo, Alberto Mastra.

- Aspamento, Gerónimo Gradito.

- Azucena, Celedonio Flores.

- Babieca, Alberto Muñoz.

- Bahía Blanca antigua, Sadoc Lameiro.

- Bailarín compadrito, Miguel Bucino. 1929.

- Bailarina de tango, Horacio Sanguinetti.

- Baile encantador, Georgina Vargas.

- Bailongo, Enrique Cadícamo.

- Balada para él, Horacio Ferrer.

- Baquiano pa'elegir, Enrique Cadícamo. 1930.

- Bar El Popular, Antonio Polito.

- Barracas, Juan Velich. 1926.

- Barrio boquense, Julio Guillán Barragán.

- Barrio Piñeiro, Dante A. Linyera.

- Barro, Horacio Sanguinetti.

- Batiendo el justo, Yacaré.

- Batilana, Virgilio Espósito. 1993.

- Bazar de la mescolanza, Ángel Villoldo. 
- Bicho raro, Enrique Diceo.

- Bien criolla y bien porteña, Homero Espósito. 1945.

- Bien de bute, Norberto Aroldi.

- Bien pulenta, Carlos Wais. 1950.

- Bigotito, Gerónimo Martinelli Massa e Ismael Aguilar.

- Boca abierta, Víctor Soliño. 1929.

- Boedo, Dante. A. Linyera. 1927.

- Boedo calle linda, Arturo Rodríguez Bustamante.

- Boliche de barrio, Nelson Pilosof. 2009.

- Bulín, Celedonio Flores.

- Cabaret, Enrique Cadícamo.

- Cabeza de indio, Juan Carlos Fernández Díaz.

- Cachá viaje, Ernesto Cardenal.

- Cacholo, Luis Roldán. 1925.

- Café de Barracas, Enrique Cadícamo.

- Café El Águila, Roberto Vidal.

- Calandria, Ángel Villoldo.

- Calandria (dejá el bodegón), Enrique Cadícamo.

- Calandria, Juan Andrés Caruso. 1926.

- Calandrias y zorzales, Andrés González Pulido.

- Calle, Alfredo Rubín.

- Callecitas de San Telmo, Mariano Canegallo.

- Campanada de largada, Juan Velich.

- Campana de plata, Samuel Linnig.

- Cancha, Enrique Dizeo.

- Canchero, Celedonio Flores. 1930.

- Canción de Buenos Aires, Manuel Romero. 1928.

- Canción de los jóvenes amantes, Horacio Ferrer.

- Canción de rango, José María Suñé. 1942.

- Cancionera, Enrique Cadícamo.

- Canto a la poesía, Nelson Pilosof.

- Caran ca fún, Celedonio Flores. 
- Caricias, JesúsFernández Blanco.

- Carlos Gardel C, Héctor Gagliardi.

- Carnaval de antaño, Manuel Romero.

- Chamusquina, Carlos Waiss.

- Charlatana, Franciso García Jiménez.

- Chau ventarrón, Osvaldo Ardizzone. 1974.

- Che Gomina, Horacio Ferrer.

- Chorro, Celedonio Flores.

- Chuzas, Enrique Uzal. 1953.

- Cicatrices, Enrique Maroni, 1925.

- Ciudad trepando al cielo, Héctor Negro.

- Como abrazado a un rencor, Antonio Podestá. 1930.

- Como los grandes, Carlos Lagos. 1997.

- Compadreando, Mario Soto. 1942.

- Compadrito de mi barrio, Nolo López.

- Compadrón, Enrique Cadícamo. 1927.

- Con bronca, Jaime Maspons.

- Con flauta y guitarra, Erma Suárez y Luis Caruso.

- Con olor a Papá, poema lunfardo Roberto Peregrino Salcedo.

- Con qué ventaja, Enrique Dizeo. 1959.

- Con toda la voz que tengo, Enrique Dizeo.

- Confidencias, Samy Friedenthal.

- Consejo de oro, Arquímedes Arci. 1933.

- Consejos reos, Celedonio Flores.

- Contrafilo, Dante A. Linyera.

- Coplas y flores, Francisco Brancatti.

- Corazón del arrabal, Manuel Romero.

- Corrientes bajo cero, Aldo Queirolo. 1952.

- Corto de genio, Andrés Seitún, 1924.

- Cuando el barrio se duerme, Juan Andrés Caruso.

- Cuando me entrés a fallar, Celedonio Flores.

- Cuarenta entradas, Nicolás Olivari. 1929. 
- Cuatro compases, Óscar Rubens. 1942.

- Cuatro corazones, Discépolo.

- Cuerpo de alambre, Ángel Villoldo. 1910.

- Cuidado con los 50, Ángel Villoldo. 1907.

- Culpas ajenas, Jorge Curi. 1929.

- De bulines y esquinas, Ricardo Cardone.

- De corte malevo, Roberto Vidal/Luis Perotti. 1953.

- De estirpe porteña, Celedonio Flores.

- De macho, Abel Aznar.

- De puro curda, Abel Aznar. 1957.

- De puro guapo, Juan Carlos Fernández Díaz. 1927.

- De puro guapo, Manuel Meaños. 1935.

- De salto y carta, José de Cicco.

- Declaración de amor, Rodolfo Sciamarella.

- Denle cancha a las mujeres, Evaristo Barrios.

- Descubriendo la ribera, Rubén Garello.

- Don Carlos, Raúl Castro.

- Don Juan (Mozos guapos), Alfredo Eusebio Gobbi.

- Donde vamos a parar, Ángel Greco.

- Durazno a cuarenta el ciento, Celedonio Flores.

- Echaste buena, Enrique Dizeo.

- El apache argentino, Arturo Mathón.

- El as de los ases, Celedonio Flores.

- El baribijo, Jesús Fernández Blanco. 1929.

- El Caburé, Carlos Waiss.

- El cantor de Buenos Aires, Enrique Cadícamo. 1936.

- El caprichoso, Antonio Polito/Carlos Pesce.

- El carrerito, Alberto Vaccarezza. 1928.

- El choclo, Discépolo.

- El Choclo, Marambio Catán. 1947.

- El ciruja, Alfredo Marino. 1926.

- El contrapunto, Jesús Fernández Blanco. 
- El conventillo, Arturo de la Torre y Fernando Rolón. 1965.

- EL criollo más criollo, Villoldo.

- El encopado, Enrique Dizeo. 1942.

- El entrerriano, Homero Expósito.

- El entrerriano, Vicente Planells del Campo y Oscar Amor: todo, jactancia.

- El fantasma de la Boca, Pablo Osvaldo Valle.

- El firulete, Rodolfo Taboada.

- El flete, Pascual Contursi. 1916.

- El flete. Gerónimo Gradito. 1941.

- El hijo triste, Horacio Sanguinetti.

- El llanto de Hispanoamérica, Bartolomé Aprile.

- El malevo, Maria Luisa Carnelli. 1928.

- El mangazo, Daniel Garibaldi.

- EL más pesao, Villoldo.

- El masajista, Yacaré.

- El mate, Evaristo Barrios.

- EL mayordomo, Villoldo.

- El origen, Héctor Negro.

- EL Pibe Picaflor, Arturo Rodríguez Bustamante.

- El Porteñito, Villoldo. 1903.

- El Porteñito, Carlos Pesce.

- El pregón, José González Castillo.

- El que con chicos se acuesta, Enrique Delfino.

- EL rey del cabaret, Manuel Romero. 1923.

- El taita, Silverio Manco. 1910.

- El tango no tiene contra, Andrés Chinarro. 1956.

- El tango...esa vieja voz, Germán Siojrín.

- El temblor, Pintín Castellanos.1938.

- El terrible, Ángel Villoldo.

- El tigre Millán, Francisco Canaro. 1934.

- El títere, Borges. 
- El Tordo, Teddy Peiró.

- El torito, Ángel Villoldo.

- El trompito, Enrique Cadícamo.

- El último guapo, Abel Aznar.

- El vino triste, Manuel Romero. 1939.

- En lo de Laura, Enrique Cadícamo.

- En tu barrio como en mí, Ernesto Pierro.

- Entre sueños, Francisco García Jiménez. 1928.

- Eran cinco amigos, Nolo López.

- Es el amigo que hoy necesito, José Ángel Trelles. 1975.

- Es preciso que te vayas, Celedonio Flores.

- Escuela de tango, Julio Martín.

- Espamento, Osvaldo Irureta.

- Estas cosas de la vida, Reinaldo Yiso.

- Eufemio Pizarro, Homero Manzi. 1947.

- Evocación, Armando Villador.

- Fanfarrón, Enrique Cadícamo. 1928.

- Fangal, Discépolo y H. Expósito. 1954.

- Fangio, Javier Mazzea. 1940.

- Farolito de mi barrio, José de Grandis.

- Farolito viejo, José Eneas Riu.

- Flojo, Francisco Payá.

- Frente al espejo, Marvil.

- Frente al estaño, Abel Aznar.

- Gacho gris, Juan Carlos Barthe. 1930.

- Gallinita, Marcos Brizzio Córdoba. 1942.

- Garufa en Villa Lugano, Enrique Dizeo.

- Gato, Homero Manzi.

- Gaucha, Luis Rubistein.

- Gaucho, José Sassone. 1936.

- Gaucho Facón grande, Osvaldo Bayer. 2012.

- Gigoló compadrito, Enrique Cadícamo. 
- Gimiendo, Juan Pablo Pérez.

- Gotán, Enrique Cadícamo.

- Granaderosdel amor, 1938.

- Guapo, Alfredo Faustino Roldán. 1942.

- Guapo de la guardia vieja, Enrique Cadícamo.

- Guapo sin grupo, Manuel Romero.

- Guapo y varón, Manuel Romero. 1937.

- Guarango, Luis Rubistein.

- Guitarra viajera, Arturo Galluci y José Barreiros Bazán.

- Guitarra, guitarra mía (estilo). Alfredo Lepera.

- Gurisa, Enrique García Satur. 1958.

- Hablame de frente, Reinaldo Yiso.

- Hágame el favor, José Rial. 1930.

- Hasta luego, Carlos Álvarez Pintos.

- Hipólito Irigoyen, Enrique Maroni. 1928.

- lunfardo:

- Honor gaucho, Juan Fulginiti. 1938.

- lunfardo.

- Idilio de bandoneones, Guillermo Pelayo Patterson.

- Incurable, Roberto Aubriot Barboza. 1930.

- Jacinto Chiclana, Borges. 1965.

- Julián Navarro, Alberto Vacarezza.

- Julián Pardales-Kavoer Mazzea, Roberto Vidal, Ángel Cicchetti.

- Juntemos nuestras alas, Nelson Pilosof. 2004.

- Justicia criolla, Francisco Brancatti. 1925.

- Juventud, Roberto Aubriot Barboza. 1929.

- La aguja en el pajar, Alberto Muñoz.

- La borrachera del tango, Enrique maroni.

- La bruja, Francisco Gorrindo. 1938.

- La calesita, Cátulo Castillo.

- La canción del deporte, Antonio Botta. 1933.

- La candombera, Alfredo Gobbi. 
- La cornetita, Eduardo Escaris Méndez.

- La fulana, Alberto Mastra y Luis Caruso.

- La historia de Baldomero, Ángel Villoldo. 1910.

- La milonga, Eugenio Cárdenas.

- La milonga y yo, Leopoldo Díaz Vélez.

- La Morocha,1905.

- La pastelera, Framcosc Brancatti.

- La patota, Acho Estol.

- La payanca,

- La pena del payador, Eduardo Escaris Méndez. 1945.

- La primera palabra, Horacio Ferrer.

- La puñalada, Celedonio Flores.

- La trifulca, Jesús Fernández Blanco. 1938.

- La yunta brava, Antonio Polito.

- Ley de guapos, Arturo Rodríguez Bustamante.

- Llevátelo, Rodolfo Sciammarella.

- Llorar por una mujer, Enrique Cadícamo.

- Lloró como una mujer, Celedonio Flores. 1929.

- Lo que nunca te dirán, Francisco Canaro. 1931.

- Lo que todo el mundo vio, Claudia Levy.

- Los compadritos, Enrique Cadícamo.

- Los disfrazaos, Carlos Mauricio Pacheco.

- Malevaje, Discépolo. 1929.

- Malevaje de antaño, Manuel Romero. 1930.

- Malevito, Celedonio Flores.

- Mamá, Celedonio Flores.

- Mamá yo quiero un novio, Roberto Fontaina. 1928.

- Mandria, Francisco Brancatti y Juan Velich.

- Mano brava, Enrique Cadícamo. 1941.

- Maragato, Jesús Fernández Blanco.

- Matasano, Pascual Contursi.1914.

- Maula, Víctor Soliño. 1927. 
- Me da pena confesarlo, Alfredo Le Pera y Mario Battistella. 1932.

- Me llaman el zorro, Roberto Lambertucci. 1942.

- Me llaman tango, Mario Soto.

- Medallita de los pobres, Enrique Maroni.

- Metele que son pasteles, Ivo Pelay. 1936.

- Mi viejo es amigo mío, Julio Martín. 1982.

- Mi viejo querido, Abel Azna.:

- Mil novecientos diez, Leopoldo Díaz Vélez. 1948.

- Milonga antigua, Rafael Pignataro. 1942.

- Milonga de arrabal, Manuel Meaños.

- Milonga del mozo guapo, Marcelo Garibotto.

- Milonga para un varón, Alejandro Szwarcman.

- Milonga por Celedonio, Héctor Negro.

- Milonga sentimental. Homero Manzi. 1931.

- Milonguera, Adela Balbín.

- Mineral, Pedro Maffia.

- Mis harapos, Jorge Luque Lobos.

- Mitad malevo, mitad Don Juan, Eduardo Trongé.

- Mozo guapo, Eusebio López. 1941.

- Mozo rana, Víctor Soliño.

- Mucha pinta, Claudia Levy.

- Muchacho rana, Tita Merello. 1960.

- Mujer, me has ofendido, Gardel y Razzano.

- Murió el malevo, Carlos Waiss.

- Nací en Pompeya, José Rótulo. 1949.

- Naftalina, Claudia Levy.

- No aflojés, Mario Battistella. 1933.

- No fue batidor, Germán Rienda.

- No hables mal de las mujeres, Antonio Nápoli. 1947.

- No me hablen de ella, Jorge Moreira.

- No me mientas, Celedonio Flores.

- No te engañes corazón, Rodolfo Sciamarella. 1926. 
- Noche callada, Eduardo Beccar.

- Novia, Alfredo Bigeschi y Antonio Polito.

- Nubes de humo, Manuel Romero. 1923.

- Nuestro bandoneón, Nelson Pilosof.

- Nunca es tarde, Celedonio Flores.

- Nunca más, Óscar Lomuto. 1922.

- Oiga amigo, Alfredo Navarrine.

- Olvidala hermano, Carlos Lagos. 1999.

- Oración criolla, Manuel Romero.

- Orgullo tanguero, Enrique Cadícamo.

- Pa'la muchachada, Carlos Jonsson. 1957.

- Pa'mí es igual, Enrique Cadícamo, Lucio Demare, y Roberto Fugazot.

- Pa' que bronquen los otarios, Juan Velich.

- Pa'que sepan cómo soy, Norberto Aroldi.

- Pa' que veas, Dante A. Lingera.

- Pa'l nene, Mario Battistella. 1950.

- Pampero, Edmundo Bianchi. 1935.

- Pan, Celedonio Flores. 1932.

- Pan comido, Enrique Dizeo. 1926.

- Para él que está en el cielo, Salvador Sequeira. 1956.

- Parque de los Patricios, Raúl Solé.

- Parque Patricios, Martina Iñíguez.

- Pasado florido, Enrique Cadícamo.

- Patotero sentimental, Manuel Romero. 1922.

- Perfume de percanta, Elleale Gerardi.

- Pifia, Sara Rainer.

- Pleito malevo, Raúl Hormaza.

- Por el llano, Eugenio Cárdenas. 1972.

- Por limosna no. Manuel Barros. 1956.

- Por mishé, Luis Rubistein.

- Por qué, Emilio Fresedo. 1931.

- Por qué me das dique, Luis Alonso. 
- Por seguidor y compadre, Eduardo Giorlandini.

- Por seguidora y por fiel, Celedonio Flores. 1930.

- Porque quisiste ser bueno, Jorge Moreira, Elsa Rivas y Marcelo Biondini.

- Porteñesa rea, Horacio Ferrer. 1973.

- Portero suba y diga, Luis César Amadori. 1928.

- Prosapia, Ernesto Pierro.

- Primero campaneala, Enrique Dlzeo.

- Quién tuviera dieciocho años, Guillermo Barbieri.

- Recostado en un farol, Ismael Aguilar.

- Regin, Alfredo Rubín.

- Reliquias porteñas, Celedonio Flores.

- Rinconada de mis tiempos, Francisco Laino.

- Rioja y Caseros, Antonioa Filgueira. 1945.

- Rosendo, Tito Reyes.

- Salute, Pablo Rodríguez.

- Sangre maleva, Pedro Platas y Juan Velich.

- Seguí mi consejo, Eduardo Trongé. 1929.

- Seguime corazón, Jesús Fernández Blanco.

- Sencillo y compadre, Carlos Bahr. 1941.

- Sentencia, Celedonio Flores. 1926.

- Sentimiento gaucho, Juan Adrés Caruso. 1924.

- Sentimiento malevo, Enrique Cadícamo. 1929.

- Ser hombre, Miguel Jubany.

- Serenata maleva, Mario Rada. 1931.

- Sí señor, Máximo Blostein.

- Si soy así, Antonio Botta. 1933.

- Siempre contigo, Antonio Polito.

- Siete palabras, Alfredo Bigeschi.

- Sin güelta, Evaristo Barrios.

- Sol de arrabal, Justo Ricardo Thomson.

- Sos bueno vos también, Juan Andrés Caruso. 
- Soy muchacho de la guardia. Héctor Marcó, 1942.

- Soy tremendo, Ángel Villoldo. 1906.

- Suburbio, Enrique Cadícamo.

- Suburbio, Mario Rada.

- Sueño malevo, Abel Aznar.

- Tango, Joaquín Gómez Bas.

- Tango de ayer. Enrique Cadícamo.

- Tango de lengue, Enrique Cadícamo.

- Tango de otros tiempos, Alberto Marino, Washington Reyes y Ulderino Caserio.

- Tango internacional, Horacio Ravera.

- Tango negro, Vicente Demarco. 1940.

- Tango santiagueño, Marcos Brizzio Córdoba.

- Tango te cambiaron la pinta, Tabanillo.

- Tango varón, Edgardo Acuña. 2002.

- Tango viejo, Carlos de la Púa. 1928.

- Tiempos nuevos, Manuel Romero.

- Tiempos viejos, Manuel Romero.1926.

- Tierra hermana, Eugenio Cárdenas.

- Tierra mía, Alberto Novión.

- Tocá el bandoneón, Pedrito, Horacio Ferrer. 1990.

- Tomo y obligo, Manuel Romero. 1931.

- Total pa'qué sirvo, Enrique Dizeo. 1941.

- Traiga otra caña, Alberto Novión.

- Tras tu antifaz, Eduardo Escaris Méndez. 1955.

- Traviesa, Javier Leone.

- Trovador mazorquero, Enrique Cadícamo.

- Tu boca mintió, Alberto Longo.

- Ufa, Dante A. Linyera.

- Ultratango, Ricardo Bruno.

- Un chico bien, Enrique Dizeo.

- Un gallego, Armando Tagini. 
- Una tarde, Benjamín Tagle Lara. 1927.

- Valsecito de antes, Homero Manzi.

- Varón, Celedonio Flores.

- Venerando su memoria, Ángel Marclay. 1956.

- Ventarrón, José Horacio Staffolani. 1933.

- Viejo parque Patricios, Antonio Macchia.

- Viejo smoking, Celdonio Flores. 1930.

- Viejo verde, Pipio Cipolatti.

- Viento solo. Alfredo Rubín.

- Viva la patria, Francisco García Jiménez.

\section{POEMAS LUNFARDOS:}

- Gomía, José María Otero.

- Guitarra maleva, Celedonio Flores.

- Herencia, Nélida E. Vázquez.

- Historias de un bandoneón con alas, Silvia Spitalnik.

- Humos de bailarín, Norberto Ángel de Líbano Elorrieta.

- Julio César, Noyda Cuniberty.

- La blanca de posse, Ricardo Cardone.

- La canción de la mugre, Carlos de la Púa.

- LA epopeya del tango, Enrique Cadícamo.

- La rechiflada, Julián Centeya.

- Oro viejo, Celedonio Flores.

- Plegaria rea, Alcides Gandolfi Herrero.

- Salve maestro, Francisco Raimundo.

- Se rechifló la percanta, Silverio Manco.

- Tango macho, Bartolomé Aprile.

- Villa Crespo, Celedonio Flores. 
Apéndice $B$

Listado de audios y vídeos recogidos en DVD adjunto:

- Espectáculo de El Chúcaro y el Ballet Folclórico Nacional, El origen del tango, parte 1 y 2.

- Estilos de tango:

- Canyengue:

- El Cachafaz.

- Gustavo Negrotto y Laura Collavini.

- Mirta Sol y Luis Grondona.

- Tango salón y milonguero:

- Jorge García.

- Susana Miller.

- Toto Faraldo.

- Tango escenario: ganadores del Mundial de Tango entre los años 2003 y 2019.

- Tango nuevo:

- Gustavo Naveira.

- Chicho Frúmboli.

- Entrevistas a Julio Sosa:

- Radio El Pueblo.

- Radio LU2 Bahía Blanca.

- Imágenes de parejas de hombres bailando. 


\section{Bibliografía}

En esta bibliografía presentamos, por una parte, las fuentes primarias consultadas para el desarrollo de nuestro estudio y, a continuación, un listado de referencias bibliográficas secundarias. Estos listados no representan el conjunto de todas las obras consultadas, sino que hemos seleccionado aquellas que nos parecen de imprescindible consulta para el profundo entendimiento de nuestras conclusiones.

1. Fuentes primarias.

Barreiro, Javier. El tango hasta Gardel. Zaragoza: Ed. Diputación provincial de Zaragoza, 1986.

Bates, Héctor y Luis J. Historia del Tango. Buenos Aires: Talleres Gráficos de la Compañía General Fabril Financiera, 1936.

Benedetti, Héctor. Nueva historia argentina. De los orígenes al siglo XXI. Buenos Aires: Siglo veintiuno editores, 2015.

Borges, Jorge Luis. Borges el memorioso. Conversaciones de Jorge Luis Borges con Antonio Carrizo. México: Fondo de cultura económica, 1986.

- El elogio de la sombra. Barcelona: RBA Coleccionables, 2005.

- El idioma de los argentinos. Madrid: Biblioteca Borges. Alianza Editorial, 2008.

- El otro, el mismo. Obras completas I. Barcelona: RBA Coleccionables, 2005.

- El tango. Cuatro conferencias. Barcelona: Ed. Lumen, 2016.

- El tango. Cuatro conferencias. Barcelona: Ed. Lumen, 2016.

- Evaristo Carriego. Buenos Aires: Alianza Editorial, 2008. 
— Evaristo Carriego. Madrid: Alianza Editorial, 2008.

- Historia Universal de la Infamia. Obras Completas I. Barcelona: RBA Coleccionables, 2005.

- Para las seis cuerdas. Obras Completas I. Barcelona: RBA Coleccionables, 2005.

— Ascendencias del tango», Martín Fierro 37 (1927), 296, https://ahira.com.ar/ejemplares/37/.

Borges, Jorge Luis y Bullrich, Silvina. El compadrito. Buenos Aires: Ed. Emecé, 2000.

Carriego, Evaristo. «El alma del suburbio», Caras y Caretas, 473 (1907).

Carriego, Evaristo. «El guapo», El Guapo. https://www.biblioteca.org.ar/libros/1176.pdf

Conde, Oscar. Diccionario etimológico del lunfardo, $3^{\mathrm{a}}$ ed. Buenos Aires: Ed. Taurus, 2019.

Del Mazo, Marcelo. Los vencidos. Buenos Aires: La Editorial argentina, 1910.

Ernesto Sábato. Tango, discusión y clave. Buenos Aires: Editorial Losada. 1963.

Flores, Celedonio. Cancionero. Buenos Aires: Torres Agüero Editor. 1977.

Gobello, José. Aproximación al lunfardo. Buenos Aires: Ediciones de la Universidad católica argentina. 1996.

- Diccionario Lunfardo. Buenos Aires: Ed. A. Peña Lillo. 1975.

Gobello, José e Amuchástegui, Irene. Vocabulario ideológico del Lunfardo. Buenos Aires: Editorial Corregidor. 1998.

Güiraldes, Ricardo. Don Segundo Sombra. Madrid: Ediciones Cátedra, 1998. 
Lamas, Hugo y Binda, Enrique. El tango en la sociedad porteña. 1880-1920. Stuttgart: Editorial Abrazos, 2008.

Lima, Nicanor. El tango argentino de salón: método de baile teórico y práctico. $1^{\text {a }}$ Parte. Edición de Autor (¿1916?)

Lugones, Leopoldo. El Payador. Hijo de la Pampa. Buenos Aires: Otero \& Co Impresores. 1916.

Mallea, Eduardo. La ciudad junto al río inmóvil, $5^{\mathrm{a}}$ ed. Buenos Aires: Editorial Sudamericana. 1975.

Matamoro, Blas. La ciudad del tango. Tango histórico y sociedad, $2^{\mathrm{a}}$ ed. Buenos Aires, Editorial Galerna, 1982.

Norese, Marta Rosalía. Contextualización y análisis del tango. Sus orígenes hasta la aparición de la vanguardia. Salamanca: Ediciones Universidad de Salamanca, 2002.

Piñero, Sergio. «Salvemos el tango», Martín Fierro, 19 (1925), 128, https://ahira.com.ar/ejemplares/19/.

Rossi, Vicente. Cosas de negros. Buenos Aires: Hachette, 1958.

Selles, Roberto y Benarós, León. La Historia del Tango. Vol. 2. Buenos Aires: Ed. Corregidor, 1977.

Sosa, Julio. Dos horas antes del alba. Buenos Aires: Editorial Logos, 1960.

2. Bibliografía secundaria.

Alberto R. Lettieri. «De la "República de la Opinión" a la "República de las instituciones"» en La Nueva Historia Argentina. Tomo 4. Buenos Aires: Editorial Sudamericana. 1998.

Archetti, Eduardo P. «Masculinidades múltiples. El mundo del tango y del fútbol en la Argentina» en Daniel Balderston (comp.) y 
Donna J. Guy (comp.), Sexo y sexualidades en América Latina. Buenos Aires: Paidós. 1998.

Assunçao, Fernando. El tango y sus circunstancias. Buenos Aires: Ed. El Ateneo, 1984.

- Pilchas criollas. Usos y costumbres del gaucho. Buenos aires: Emecé. 2000.

Ben, Pablo. «Plebeian Masculinity and Sexual Comedy in Buenos Aires, 1880-1930», Journal of the History of Sexuality, Vol. 16, № 3 (2007): 436.

Benarós, León. "La vida de "El Chúcaro" contada por él mismo. En diálogos con León Benarós», Folclore, 9 (1962): 6. Disponible en https://ahira.com.ar/ejemplares/folklore-no-9/

— «La vida de El Chúcaro contada por él mismo», Folclore, 9 (1962): 9.

Berti, Eduardo. Por qué escuchamos a Aníbal Troilo. Buenos Aires: Gourmet musical, 2017.

Bockelman, Brian. «Between the Gaucho and the Tango: Popular Songs and the Shifting Landscape of Modern Argentine Identity, 1895-1915», The American Historical Review, Vol. 116, $\mathrm{n}^{\circ}$ 3 (2011): 578.

Canaro, Francisco. Mis memorias (1906-1956). Mis bodas de oro con el tango. Buenos Aires: CESA Talleres gráficos S.R.L, 1957.

Carozzi, María Julia. Aquí se baila el tango. Una etnografía de las milongas porteñas. Buenos Aires: Siglo veintiuno editores, 2015.

Casas, Matías Emiliano. «Representaciones y publicaciones sobre el gaucho argentino en la década del treinta. Entre la identidad nacional, el campo literario y las estrategias comerciales», Historia y Memoria, 11. Colombia: Universidad Pedagógica y Tecnológica, 2015, 151-176. 
Cecconi, Sofia. «Tango Queer: territorio y performance de una apropiación divergente». Trans, 13 (2009).

Claire, Elizabeth. «Dance practice and gendered discourse», Clio. Women, Gender, History, 46 (2017): 9.

Collier, Simon. Carlos Gardel. Su vida, su música, su época. Buenos Aires: Plaza y Janés editores, 1988.

Conde, Oscar. Lunfardo. Un estudio sobre el habla popular de los argentinos. Buenos Aires: Taurus, 2011.

Corbiere, Emilio P. El gaucho: desde su origen hasta nuestros días, $2^{\text {a }}$ ed. Sevilla: Renacimiento, 1998.

Cruz Guillén, Juan. Santiago Ayala "El Chúcaro" y Norma Viola. Antes y después, $2^{\mathrm{a}}$ ed. Buenos Aires: Balletin Dance Ediciones, 2015.

Domínguez. María Eugenia. «Música negra en el Río de la Plata: definiciones contemporáneas entre los jóvenes de Buenos Aires». Trans, 12 (2008).

Favio Shifres, Alegandro Pereira Ghiena, Romina Herrera y Mariana Bordoni, «Estilo de ejecución musical y de danza en el tango: atributos, competencia y experiencia dinámica», Cuadernos de Música, Artes Visuales y Artes escénicas 7 (2):86, https://doi.org/10.11144/Javeriana.mavae7-2.eemd.

Ferrari, Lidia. Tango. Arte y misterio de un baile. Buenos Aires: Ediciones Corregidor. 2017.

Flores, Celedonio. Cuando pasa el organito. Buenos Aires: Ed. Freeland. 1965.

Gallardo, Jorge Emilio. El nacimiento del gaucho. Buenos Aires: Idea viva, 2000.

Gesualdo, Vicente. La Música en la Argentina. Buenos Aires: Editorial Stella, 1988.

Gobello, José. Lunfardía. Buenos Aires: Argos, 1953. 
Grimson, Alejandro. Mitomanías argentinas. Cómo hablamos de nosotros mismos. Buenos Aires, Siglo XXI editores. 2013.

Guibert, Fernando. El compadrito y su alma. Buenos Aires: Editorial Perrot. 1957.

Ibarguren, Carlos. De nuestra tierra. Buenos Aires: Sociedad Cooperativa Editorial Limitada. 1917.

Iriarte, Florencio. "Batifondo a la villa de Roi», Don Basilio (1900) en La historia del tango. Buenos Aires: Ediciones Corregidor. 1976.

Jara, Juan Carlos. Celedonio Flores. Por qué canto así. Buenos Aires: Ministerio de cultura argentina. 2015.

Kimmel, Michael. «Homofobia, temor, vergüenza y silencio en la identidad masculina», en Teresa Valdés y José Olavarría (eds.) Masculinidad/es. Poder y crisis. Ediciones de las Mujeres, $\mathrm{n}^{\circ}$ 24. Isis Internacional-Flacso Chile.p.49 citado en María José Jociles Rubio, El estudio sobre las masculinidades. Panorámica general. Gazeta de Antropología 2001, 17, artículo 27.

Kohan, Pablo. "Carlos Vega y la teoría hispanista del origen del tango» (Buenos Aires: Facultad de Filosofía y Letras, UBA, 2007) en http://repositorio.filo.uba.ar/handle/filodigital/7626

Laguarda Visillac, C. «Carlos Gardel símbolo de la patria rioplatense» en Carlos Gardel y la prensa después de su muerte. 1935-1950 (Buenos Aires, Ediciones Corregidor, 2014), 100-105.

Lencina, Héctor. «En los recuerdos de Mona Maris, Gardel era un hombre bien viril, pero algo tímido con las mujeres» en Carlos Gardel y la prensa después de su muerte. 1950-2005 (Buenos Aires, Ediciones Corregidor, 2014), 343.

Liska, María Mercedes. «El tango como disciplinador de cuerpos ilegítimos-legitimados». Trans, 13 (2009) en https://www.sibetrans.com/trans/articulo/53/el-tango-comodisciplinador-de-cuerpos-ilegitimos-legitimados. 
Lobato, Mirta Zaida y Suriano, Juan. Nueva historia Argentina. Buenos Aires: Editorial Sudamericana. 2000.

Maristany, José Javier y Peralta, Jorge Luis. «Masculinidades: modelos para (des)armar», Maristany, José Javier y Peralta, Jorge Luis (comp.) Cuerpos minados. La Plata: Editorial de la Universidad Nacional de La Plata, 2017.

Martínez Estrada, Ezequiel. Radiografía de la Pampa. Madrid: Consejo Superior de Investigaciones Científicas. 1991.

Muñoz Sánchez, Hernando. «Hacerse hombres: la construcción de masculinidades desde las subjetividades: un análisis a través de relatos de vida de hombres colombianos». Tesis doctoral. Universidad Complutense de Madrid. 2015.

Novati, Jorge (Coord.) Antología del tango rioplatense. Vol. 1. Buenos Aires: Instituto nacional de Musicología Carlos Vega. 1980.

Parkinson de Saz, Sara. «EL gaucho en la vida y literatura argentina». Don Segundo Sombra. Madrid: Ediciones Cátedra, 1998.

Pau, Antonio. Música y poesía del tango. Madrid: Trotta, 2001.

Pelinski, Ramón, ed. El tango nómade. Ensayos sobre la diáspora del tango. Buenos Aires: Corregidor, 2000.

Peluso, Hamlet y Visconti, Eduardo eds. Carlos Gardel y la prensa después de su muerte. 1935-1950. Buenos Aires: Ediciones Corregidor, 2014.

- Carlos Gardel y la prensa después de su muerte. 19502005. Buenos Aires: Ediciones Corregidor. 2014.

Peris Llorca. «La modernidad de la tradición. Nueve versiones literarias del gaucho en la formación del imaginario nacional argentino (1880-1930)». Universidad de Valencia. 2014.

Rivero, Edmundo. Una luz de almacén (El lunfardo y yo). Buenos Aires: Emecé editores, 1982. 
Sábato, Ernesto «La tristeza de los argentinos», Gaceta Literaria 12, Año II (1958).

Saikin, Magali. Tango y género. Identidades y roles sexuales en el Tango Argentino. Stuttgart: Editorial Abrazos books. 2004.

Salas, Horacio. Borges. Una biografía. Buenos Aires: Editorial Planeta. 1994.

—El tango, $4^{\mathrm{a}}$ ed. Buenos Aires: Ed. Planeta, 1999.

Sargento Pita [seud.], «El tango criollo». Caras y Caretas (1903).

Savigliano, Marta. «Malevos, llorones y percantas retobadas: el tango como espectáculo de razas, clases e imperialismo», en Relaciones de la Sociedad Argentina de Antropología, 19 (1994).

- Tango and the political economy of passion. Boulder, Colorado: Westview Press, 1995.

Scarano, Laura Rosana. «Hacia una nueva ética del coraje: un guapo de 900 de Samuel Eichelbaum». Revista Letras, 37. Universidad Nacional de Mar del Plata (2010).

Silva Valdés, Fernán. «Croquis para un tango», Cartel, Año I, n' III (1930).

- Agua del tiempo. Buenos Aires: Editorial Claridad, 1925.

Silvestre Otazú, «Cesar Ratti evoca la figura de Gardel» en Carlos Gardel y la prensa después de su muerte. 1935-1950 (Buenos aires, Ediciones Corregidor, 2014), 192.

Silvestre, Gabriela. «El imaginario paisajístico en el litoral y el sur argentinos». La Nueva Historia Argentina. Tomo 4. Buenos Aires: Editorial Sudamericana. 1998.

Sorrentino, Fernando. Siete conversaciones con Jorge Luis Borges. Buenos Aires: Editorial el Ateneo. 1999. 
Varela, Alfredo. «El pianista de Gardel y de la Pavlova, recuerda...» en Carlos Gardel y la prensa después de su muerte. 1935-1950. Buenos Aires: Ediciones Corregidor, 2014.

Vega, Carlos. Las danzas populares argentinas. Buenos Aires: Instituto nacional de Musicología Carlos Vega. 1986.

\section{Recursos on line}

Andahazi Federico. «Los amores de Carlos Gardel». Acceso el 20 de marzo de 2020. https://radiomitre.cienradios.com/losamores-de-carlos-gardel-por-federico-andahazi/

Astarita, Gaspar. «Dos amigos: Enrique Dizeo y Celedonio Flores». Acceso el 20 de febrero de 2021. https://www.todotango.com/historias/cronica/77/Dos-amigos:Enrique-Dizeo-y-Celedonio-Flores/

Binda, Enrique. "¿Tango rioplatense o tango argentino?». Acceso el 18 de enero de 2021. https://www.todotango.com/historias/cronica/212/Tangorioplatense-o-tango-argentino/

Cohen, Matt, Folsom, Ed and Price, Keneth M. (Eds), The Walt Whitman Archive. Acceso el 10 de febrero de 2020. https://whitmanarchive.org/.

Dizeo, Enrique. «Trovero», en Pablo Taboada, «Poemas a poetas. Parte I. Celedonio y Dizeo. Recuerdos de Julián Centeya». $\begin{array}{lllll}\text { Acceso el } & 17 \text { de febrero de } 2021 .\end{array}$ http://www.investigaciontango.com/inicio/index.php?option=com_c ontent\&view=article\&id=125:celedonio-dizeo-ycenteya\&catid=43: poetas\& $\mid$ temid $=63$

Fidel López, Vicente. «Fisonomía del mes». La Revista del Río de la Plata. (1871). Acceso el 20 de junio de 2021. http://www.cervantesvirtual.com/nd/ark:/59851/bmc9c7p1 
Gasparri, Javier. «Che varón, masculinidades en las letras de tango».

Caracol, diciembre

(2011), https://www.researchgate.net/publication/281007509_Che_varon_ masculinidades_en_las_letras_de_tango

Güiraldes, Ricardo. El cencerro de cristal, Biblioteca Virtual Miguel de Cervantes. Acceso el 20 de junio de 2021. http://www.cervantesvirtual.com/obra-visor/el-cencerro-de-cristal-0/html/ff2a4102-82b1-11df-acc7-002185ce6064_3.html\#I_0_

Hemeroteca Digital de la Biblioteca Nacional de España. Acceso el 21 de junio de 2021. http://www.bne.es/es/Catalogos/HemerotecaDigital/

Luengo López, Jordi. «ĺdolos populares de latina masculinidad. Valentino, Gardel y, otros "violeteros modernistas». Culturas populares. Revista Electrónica 7 (2008). Acceso el 21 de junio de 2021. http://www.culturaspopulares.org/textos7/articulos/luengo.pdf

Ministerio de Cultura Argentina. "¿Cuáles son las danzas típicas de la Argentina?». Acceso el 17 de febrero de 2021. https://www.cultura.gob.ar/que-conocemos-acerca-de-nuestrasdanzas-8433/

Peña, Juan Manuel. «Ricardo Güiraldes, el gaucho que bailó el tango», La Nación 2009. Acceso el 25 de enero de 2021. https://www.lanacion.com.ar/1119447-ricardo-guiraldes-el-gauchoque-bailo-tango 5

Plesch, Melanie. «El rancho abandonado. Algunas reflexiones en torno a los comienzos del nacionalismo musical en la Argentina». La historia de la payada (1992). Acceso el 25 de enero de 2021. http://anaforas.fic.edu.uy/jspui/handle/123456789/43632?mode=ful I

REAL ACADEMIA ESPAÑOLA: Diccionario de la lengua española, 23. ${ }^{a}$ ed., [versión 23.4 en línea]. <https://dle.rae.es> 
Rosario cine. Acceso el 16 de abril de 2021. http://www.rosariocine.com.ar/pelicula/grease-el-compadrito-43

Rossi, Rodolfo J. «Leopoldo Lugones: Vida y muerte de un enemigo del Tango», Tangoreporter, (2007). Acceso el 25 de enero de 2021. http://tangoreporter.blogspot.com/2007/03/leopoldolugones-vida-y-muerte-de-un.html (1 de febrero de 2021)

Vargas Vera, René. «Ayer habría cumplido 75 años. Julio Sosa dejó su marca en el tango», La Nación, (2001). Acceso el 25 de enero de 2021. https://www.lanacion.com.ar/espectaculos/juliososa-dejo-su-marca-en-el-tango-nid50913/

Vautier, Camila. «Resistiendo con abrazos: un estudio sobre representaciones de masculinidades hegemónicas y emergentes en el tango platense», Repositorio Institucional de la UNLP. Acceso el 25 de junio de 2021. http://sedici.unlp.edu.ar/handle/10915/64424

Vega, Carlos. Estudios para los orígenes del tango argentino. Buenos Aires: Universidad Católica Argentina, Instituto de Investigación Musicológica Carlos Vega, 2016. Acceso el 25 de enero de 2021. http://bibliotecadigital.uca.edu.ar/repositorio/libros/origenes-tangoargentino-vega.pdf 